FLAVIO AUGUSTO JACOB PARADA FRANCH

INFLUÊNCIA DO TIPO DE REVESTIMENTO SUPERFICIAL NO FLUXO NÃO SATURADO E SUA INFLUÊNCIA NA ESTABILIDADE DE

\title{
TALUDES
}

Dissertação apresentada à Escola Politécnica da Universidade de São Paulo, para obtenção do título de Mestre em Engenharia

São Paulo

2008 - (Edição Original)

2008 - (Edição Revisada) 
FLAVIO AUGUSTO JACOB PARADA FRANCH

\section{INFLUÊNCIA DO TIPO DE REVESTIMENTO SUPERFICIAL NO FLUXO NÃO SATURADO E SUA INFLUÊNCIA NA ESTABILIDADE DE}

TALUDES

Dissertação apresentada à Escola Politécnica da Universidade de São Paulo, para obtenção do título de Mestre em Engenharia

Área de Concentração: Engenharia Geotécnica

Orientador: Prof. Doutor Marcos Massao Futai

$$
\begin{gathered}
\text { São Paulo } \\
2008 \text { - (Edição Original) } \\
2008 \text { - (Edição Revisada) }
\end{gathered}
$$




\begin{abstract}
AUTORIZO A REPRODUÇÃO E DIVULGAÇÃO TOTAL OU PARCIAL DESTE TRABALHO, POR QUALQUER MEIO CONVENCIONAL OU ELETRÔNICO, PARA FINS DE ESTUDO E PESQUISA, DESDE QUE CITADA A FONTE.
\end{abstract}

Este exemplar foi revisado e alterado em relação à versão original, sob responsabilidade única do autor e com a anuência de seu orientador.

São Paulo, 26 de Julho de 2008-07-

Assinatura do autor

Assinatura do orientador

FICHA CATALOGRÁFICA

Franch, Flavio Augusto Jacob Parada

Influência do tipo de revestimento superficial no fluxo não saturado e sua influência na estabilidade de taludes / F.A.J.P. Franch. -- São Paulo, 2008.

202 p.

Dissertação (Mestrado) - Escola Politécnica da Universidade de São Paulo. Departamento de Engenharia de Estruturas e Geotécnica.

1.Solo não saturado 2.Taludes (Estabilização) I.Universidade de São Paulo. Escola Politécnica. Departamento de Engenharia de Estruturas e Geotécnica II.t. 
DEDICATÓRIA

Dedico este trabalho à minha família e em especial ao meu filho André. 


\section{AGRADECIMENTOS}

Ao Prof. Dr. Marcos Massao Futai por seu apoio e incentivo ao longo de todo trabalho, com orientações precisas e de bom senso considerando as dificuldades inerentes à execução de pesquisa em campo. Em cada etapa dos trabalhos pudemos contar com sua presença, empenho e disposição para encontrar alternativas e soluções para as dificuldades encontradas. Debates intensos sobre a interpretação de resultados não faltaram, o que levou-nos a tomar decisões sábias, prudentes e fundamentadas.

Ao Prof. Dr. Carlos de Souza Pinto por suas sugestões, comentários e incentivo, e pelas críticas construtivas que nos permitiram manter a pesquisa em direção certeira. Ao Prof. Dr. Fernando Marinho por seu apoio na disponibilização de equipamentos e recursos do Laboratório de Mecânica dos Solos, inclusive pela iniciativa e disposição para execução de ensaio "in situ" num sábado ensolarado. Ao laboratorista Antônio C. Heitzmann por seu apoio fundamental.

Agradeço em especial a minha mãe por sua visão e orientação sobre o crescimento, desenvolvimento e preparação para o futuro que um curso de mestrado pode trazer, aliado à experiência profissional. Incentivos e apoio fundamentais recebi de duas pessoas que me marcaram: Vera Cecília B. Pereira e Irani de Barros. Estímulos de perseverança, foco e disciplina recebi sempre que faltaram de Miriam Leal.

Às empresas Herjack Engenharia e BVP Engenharia, na pessoa de seus diretores, agradeço a possibilidade de integrar o dia-a-dia do trabalho com as demandas do programa de mestrado. À Prefeitura Municipal de São Paulo pela autorização para realizar a pesquisa em área de sua propriedade. E finalmente à Franch Engenharia e Consultoria de Fundações e ao CNPq pelo apoio financeiro à pesquisa. 


\section{RESUMO}

Taludes formados por solos na condição não saturada são muito comuns no Brasil. Nestes casos a poro-pressão de água contribui para a estabilidade desses taludes. Este trabalho pretende avaliar o efeito do tipo de revestimento superficial na alteração do perfil de poro-pressão de água provocado por fluxos gerados a partir de precipitações, evaporação e evapo-transpiração, e conseqüentemente na estabilidade de talude experimental. São apresentadas aqui as características geológico-geotécnica, geomorfológica, climática e pluviométrica de campo experimental implantado na zona leste de São Paulo/SP, onde foram instalados e monitorados tensiômetros, pluviômetro e medidor de nível d'água por um período oito meses. Resultados de ensaios de caracterização, resistência e obtenção das propriedades hidráulicas dos solos que compõem o maciço estudado são analisados, assim como ensaios realizados com a argamassa de revestimento do talude, ensaios para a análise do funcionamento dos tensímetros e tubos tensiométricos utilizados no monitoramento, e outros ensaios realizados "in situ". O monitoramento realizado indicou coerência entre precipitações e variação da poropressão de água, e variação do nível d'água do terreno, em ambos os tipos de revestimento superficial, vegetação natural e argamassa, nos dois tipos de solo presentes no maciço. Análises de estabilidade do talude indicaram o efeito do tipo de revestimento superficial e das variações sazonais de poro-pressão de água no fator de segurança ao escorregamento do talude.

Palavras-chave: Solo não saturado. Fluxo não saturado. Monitoramento de sucção. Estabilidade de taludes. 


\section{ABSTRACT}

Slopes formed by unsaturated soils are very common in Brazil. In these cases porewater pressure contribute for the slope stability behavior. This work aims at evaluating the effects of types of superficial coating on the profile of pore-water pressure changes, due to flow generated by precipitation, evaporation and evapotranspiration, and consequently on the stability of a experimental slope. It is presented here the geological-geotechnical, geomorfological, climatic and pluvial characterizations of the experimental field located in the east zone of São Paulo/SP, where have been installed and monitored tensiometers, pluviometer and groundwater level measurer during eight months. Results of tests of characterization, shear strength, and for obtaining the hydraulic properties of the "in situ" soils are analyzed, as well as the tests carried out with de mortar applied over the slope, as well as the functionality tests for the tensimeters and tensiometric tubes used on the monitoring, as well as other "in situ" tests. Monitoring indicated coherence between precipitation and change in pore-water pressure profile, and groundwater level, in both types of superficial coatings, natural vegetation and mortar, and in both types of "in situ" soils. Stability analyzes indicated the effect of the type of superficial coating and of the variation of pore-water pressure profile, during the experiment, on the factor of safety of the experimental slope.

Keywords: Unsaturated soil. Non saturated flow. Suction monitoring. Slope stability. 


\section{SUMÁRIO}

1. INTRODUÇÃO 1

2. ASPECTOS TEÓRICOS SOBRE O FLUXO NÃO SATURADO E SUA

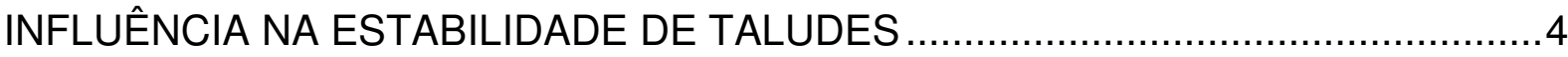

2.1 Conceitos gerais da mecânica dos solos não saturados ............................4

2.1.1 Curva de retenção para os solos não saturados ................................4

2.1.2 Coeficiente de condutividade hidráulica para os solos não saturados ........6

2.1.3 Resistência ao cisalhamento dos solos não saturados ............................

2.1.4 Comportamento das bolhas de ar oclusas em solos não saturados .........14

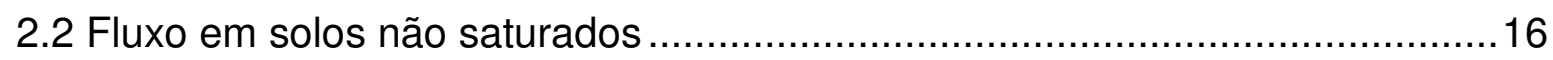

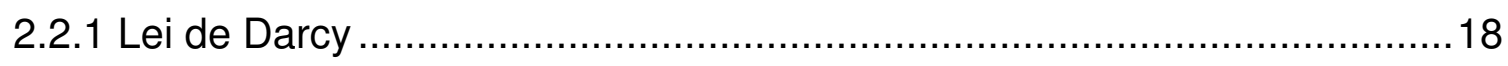

2.2.2 Equações de fluxo não saturado propostas por Fredlund e Rahardyo .....23

2.2.3 Variáveis que influenciam fluxo não saturado e a estabilidade de taludes25

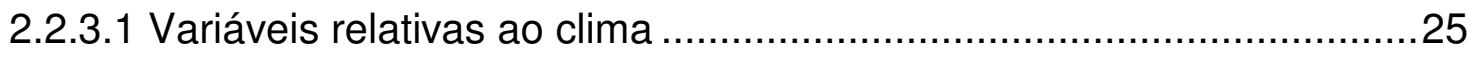

2.2.3.2 Variáveis relativas ao tipo de revestimento superficial .....................27

2.2.3.3 Variáveis relativas às propriedades do solo ...................................29

2.2.4 Modelos de previsão da infiltração em solos não saturados ....................33

2.2.4.1 Modelo de Green Ampt............................................................33

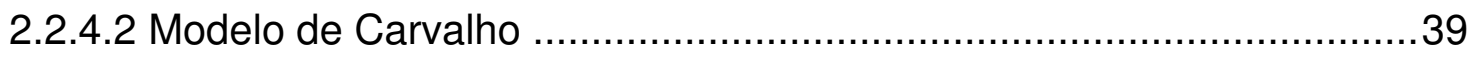

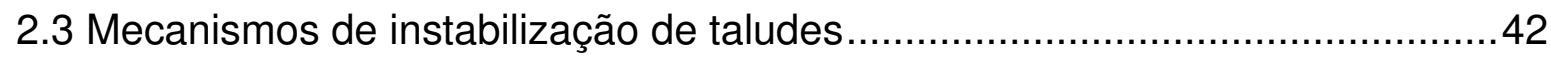

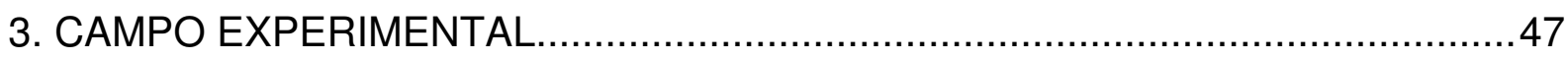

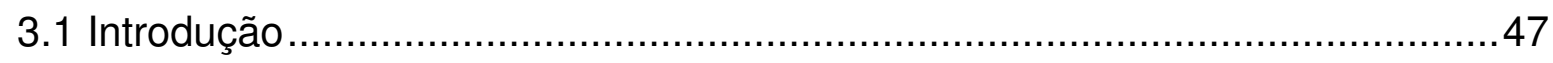

3.2 Caracterizações geológico-geotécnica e geomorfológica.............................50

3.3 Caracterizações climática e pluviométrica ........................................... 54

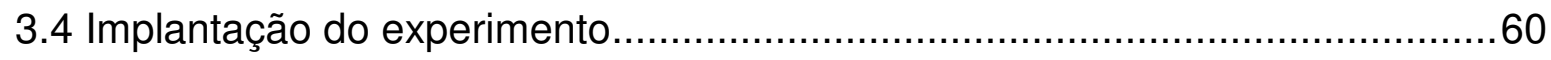

3.4.1 Descrição dos tensiômetros e tubos tensiométricos .............................62 
3.4.2 Instalação dos tubos tensiométricos .65

4. RESULTADOS E ANÁLISES DOS ENSAIOS LABORATORIAIS E DE CAMPO .66

4.1 Ensaios para análise do funcionamento do tensímetro .66

4.1.1 Ensaios com tensímetro em laboratório ……………………….............66

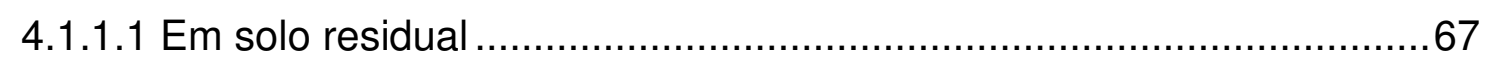

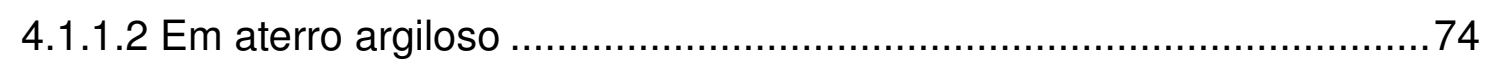

4.1.2 Ensaios com tensímetro em campo …………….............................76

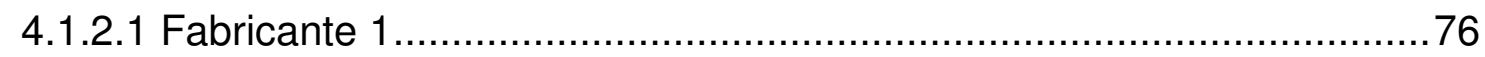

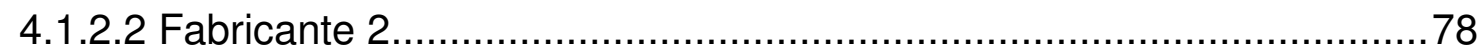

4.1.3 Comparação dos ensaios em laboratório com os de campo......................81

4.1.4 Dificuldades encontradas no monitoramento com tensímetro...................82

4.2 Ensaios com os solos do campo experimental ...........................................83

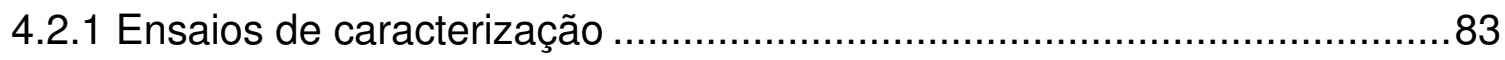

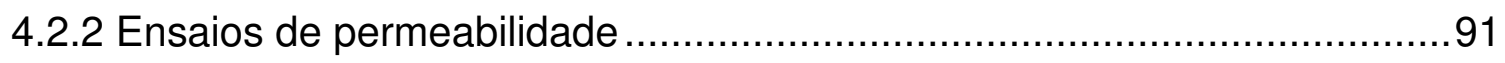

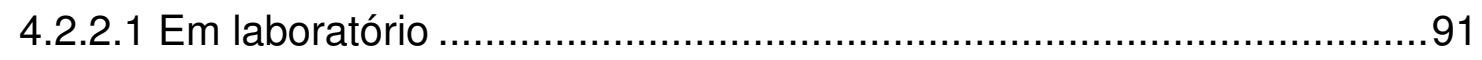

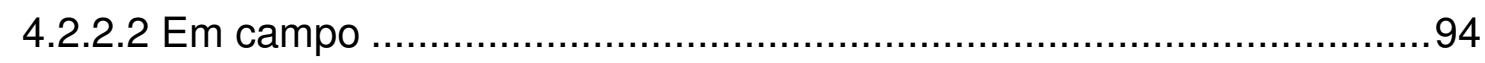

4.2.3 Curva de retenção e função permeabilidade...........................................95

4.2.4 Ensaios para determinação da resistência não saturada........................100

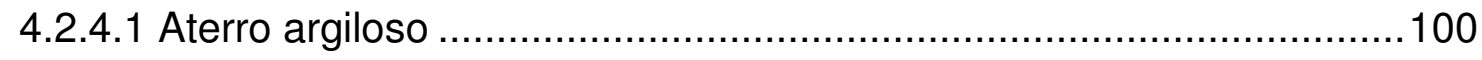

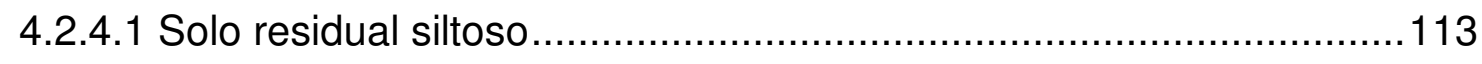

4.3 Ensaio de permeabilidade com argamassa de revestimento........................126

4.4 Ensaio de infiltração em infiltrômetro de duplo-anel com medição de poro-

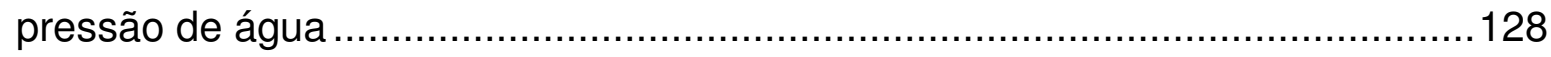

5. MONITORAMENTO DO TALUDE EXPERIMENTAL ......................................136

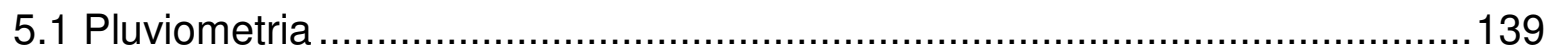

5.2 Variação do nível d'água do terreno ……………...................................141

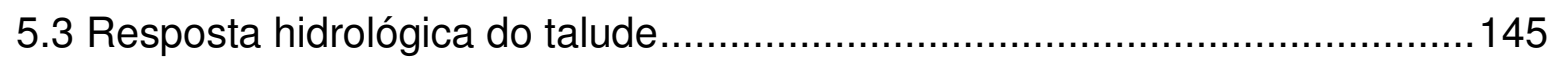


5.3.1 Série temporal de poro-pressões de água e precipitações .....................146

5.3.2 Perfis de poro-pressão de água ................................................. 153

5.3.2.1 Período de estiagem......................................................... 153

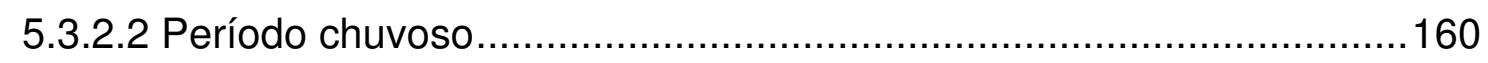

5.3.3 Distribuição de poro-pressão d'água no talude ................................ 164

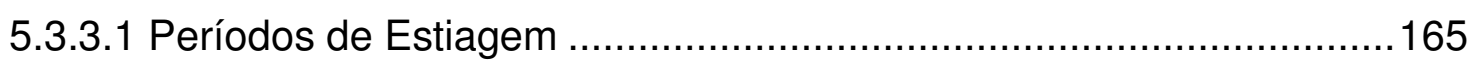

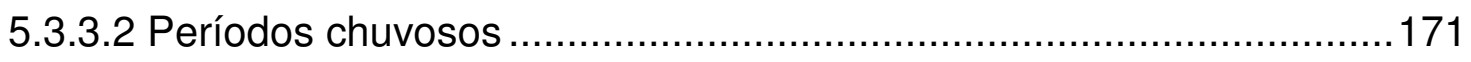

5.3.4 Conclusões sobre resposta hidrológica do talude .............................175

5.3.4.1 Comparação entre tipos de revestimentos ..............................175

5.3.4.2 Comparação entre tipos de solos .......................................176

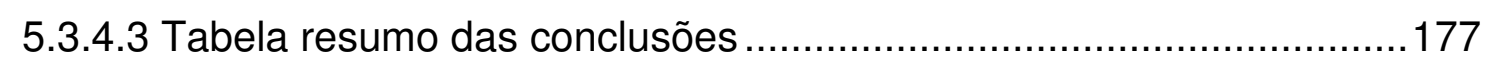

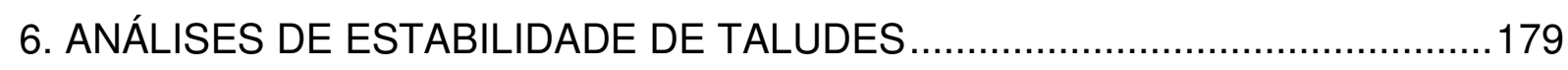

6.1 Estimativa da distribuição de poro-pressão de água em todo o maciço ........179

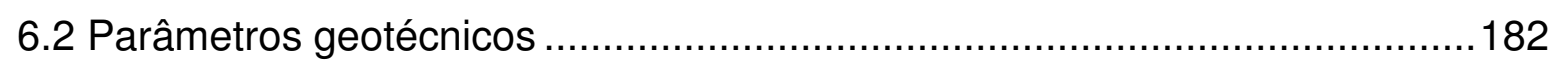

6.3 Análises de estabilidade do talude experimental .................................. 183

6.3.1 Efeito das variações sazonais da poro-pressão de água na estabilidade do

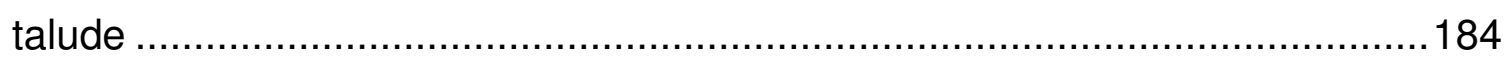

6.3.2 Efeito do tipo do revestimento superficial na estabilidade do talude .......187

7. CONCLUSÕES E RECOMENDAÇÕES PARA FUTURAS PESQUISAS ...........190

7.1 Aspectos relacionados à utilização do tensímetro .................................. 190

7.2 Aspectos relacionados aos ensaios de laboratório ................................. 191

7.3 Aspectos relacionados ao ensaio de infiltração "in situ" ...........................192

7.4 Aspectos relacionados ao monitoramento do talude experimental...............193

7.5 Aspectos relacionados às análises de estabilidade do talude experimental.. 194

7.6 Recomendações para futuras pesquisas........................................... 195

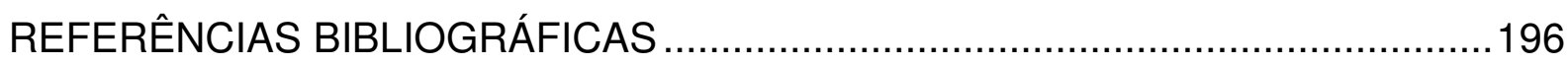




\section{LISTA DE ILUSTRAÇÕES}

\section{CAPÍTULO 2}

Figura 2.1: Curva de retenção com principais características hidráulicas de um solo 6 Figura 2.2: Variação do coeficiente de permeabilidade com a sucção. 7 Figura 2.3: Superfície de ruptura para um solo não saturado, conforme equação proposta por Fredlund et al. (1978).

Figura 2.4: Relação entre a curva de retenção e a resistência ao cisalhamento de um solo não saturado: (a) curva de retenção, e (b) envoltória não linear da resistência, Vanapalli et al. (1996).

Figura 2.5: Variação das poro-pressões de água e ar devido a alterações na tensão total durante ensaio de compressão não-drenada

Figura 2.6: Condições de equilíbrio estático e fluxo contínuo na zona de poropressões de água negativas.

Figura 2.7: Frente de umedecimento conforme prevê o modelo de Green Ampt......34

Figura 2.8: Três casos considerados no modelo de Green Ampt. 36

Figura 2.9: Perfil simplificado de infiltração segundo o Modelo de Carvalho (1989) .40 Figura 2.10: Variação da capacidade de infiltração Cl com o tempo, Carvalho (1989)

\section{CAPÍTULO 3}

Figura 3.1: Campo experimental

Figura 3.2: Cicatriz de escorregamento (2004)

Figura 3.3: Planta da área de risco geológico-geotécnico e da implantação do campo experimental. 49

Figura 3.4: Perfil geológico-geotécnico .51

Figura 3.5: Mapa Geológico do Estado de São Paulo (IPT - Instituto de ..... .52

Figura 3.6: Bloco do aterro argiloso .53

Figura 3.7: Bloco do solo residual siltoso .53

Figura 3.8: Precipitação anual nos Postos Pluviométricos da Luz (1904 a 2003) e Jardim Centenário (1973 a 1992), e precipitações anuais máximas, médias e mínimas por década. 
Figura 3.9: Curva IDF (RMSP) ..... .59

Figura 3.10: Planta de implantação da instrumentação 60

Figura 3.11: Seção 1 - Instrumentação na porção argamassada do talude 61

Figura 3.12: Seção 2 - Instrumentação na porção do talude com vegetação .62

Figura 3.13: Tensímetro digital de punção 62

Figura 3.14: Tensímetro analógico de punção 62

Figura 3.15: Tubos tensiométricos de 1,5 e 3,0 m de comprimento. .64

Figura 3.16: Detalhe da parte superior do tubo tensiométrico .64

\section{CAPÍTULO 4}

Figura 4.1: Experimento com tensímetro fornecido pelo segundo fabricante, ver parte superior da foto, realizado em laboratório. 66

Figura 4.2: Ensaio 1: Homogeneização da umidade da pasta com o material compactado. 68

Figura 4.3: Ensaio 2: Retirada e recolocação do tensímetro do tubo tensiométrico..69 Figura 4.4: Ensaio 3: Seqüência de retiradas e inserções do tensímetro, e retirada da tampa do tubo tensiométrico .70

Figura 4.5: Ensaio 4: Seqüência de retiradas e inserções do tensímetro (4 vezes), e de infiltrações de água pelo topo do cilindro de Proctor (2 vezes) 72 Figura 4.6: Ensaio 1: Homogeneização da umidade da pasta com o a argila compactada. 75

Figura 4.7: Ensaio 2: Retirada e Recolocação do Tensímetro do Tubo Tensiométrico .76

Figura 4.8: Estabilização das leituras no tensímetro, fornecido pelo fabricante 1 ....77 Figura 4.9: Estabilização das leituras no tensímetro, fornecido pelo fabricante 2.....79 Figura 4.10: Curvas granulométricas de amostras dos blocos indeformados, com e sem defloculante .84

Figura 4.11: Curvas granulométricas de amostras da sondagem a trado 1. 85

Figura 4.12: Curvas granulométricas de amostras da sondagem a trado 2 . 85

Figura 4.13: Curvas granulométricas de amostras da sondagem a trado 3. .86

Figura 4.14: Percentagem das frações granulométricas do aterro .87

Figura 4.15: Percentagem das frações granulométricas do solo residual..... .87 
Figura 4.16: Granulometria das sondagens a trado (ST) .88

Figura 4.17: Peso específico dos grãos $x$ profundidade. 89

Figura 4.18: Carta de plasticidade.

Figura 4.19: Fotos dos corpos de prova do solo residual (e), observar direção do plano de foliação indicada na figura, e do aterro (d).

Figura 4.20: Variação do coeficiente de permeabilidade com a tensão confinante...92 Figura 4.21: Direção dos fluxos $\left(\mathrm{F}_{\mathrm{V}}, \mathrm{F}_{\mathrm{H}}, \mathrm{F}_{45^{\circ}}\right)$ aplicados a amostras retiradas dos blocos indeformados .93

Figura 4.22: Vetores dos coeficientes de permeabilidade, indicando magnitude e direção.

Figura 4.23: Ensaio de Permeabilidade Guelph

Figura 4.24: Curva de retenção para o aterro argiloso: a) relação entre umidade volumétrica e sucção; b) relação entre umidade gravimétrica e sucção; c) relação entre grau de saturação e sucção; e d) relação entre índice de vazios e sucção. ....97 Figura 4.25: Curva de retenção para o solo residual siltoso: a) relação entre umidade volumétrica e sucção; b) relação entre umidade gravimétrica e sucção; c) relação entre grau de saturação e sucção; e d) relação entre índice de vazios e sucção. ....98 Figura 4.26: Função condutividade hidráulica do aterro argiloso e do solo residual siltoso, na direção $45^{\circ} \mathrm{com}$ a horizontal. 99

Figura 4.27: Gráfico do deslocamento vertical em função do deslocamento horizontal, nos ensaios com a argila inundada, de acordo com a tensão vertical aplicada.

Figura 4.28: Gráfico da tensão cisalhante em função do deslocamento horizontal, nos ensaios com a argila inundada, de acordo com a tensão vertical aplicada ......102 Figura 4.29: Gráfico do deslocamento vertical em função do deslocamento horizontal, nos ensaios com a argila não saturada, de acordo com a tensão vertical aplicada e com a sucção do corpo de prova ao final do ensaio 103

Figura 4.30: Gráfico da tensão cisalhante em função do deslocamento horizontal, nos ensaios com a argila não saturada, de acordo com a tensão vertical aplicada e com a sucção do corpo de prova ao final do ensaio 104

Figura 4.31.: Envoltórias de resistência da argila, para os ensaios de cisalhamento direto inundados e não saturados 
Figura 4.32: Tensão desviadora em função da deformação axial específica para os ensaios de compressão simples realizados no aterro argiloso, realizados com várias sucções iniciais

Figura 4.33: Sucção em função da deformação axial específica para os ensaios de compressão simples realizados no aterro argiloso, realizados com várias sucções iniciais

Figura 4.34: Tensão desviadora em função da sucção do corpo de prova para os ensaios de compressão simples realizados no aterro argiloso 108

Figura 4.35: Envoltórias de resistência da argila, para os ensaios de compressão simples 109

Figura 4.36: Interpretação dos ensaios de compressão simples e cisalhamento direto realizados no aterro não saturado

Figura 4.37: Ajustes do intercepto de coesão com ângulo de atrito constante, para os ensaios de cisalhamento direto e compressão simples não saturados, na argila ...112 Figura 4.38: Gráfico do deslocamento vertical em função do deslocamento horizontal, no ensaio com o silte inundado, de acordo com a tensão normal aplicada

Figura 4.39: Gráfico da tensão cisalhante em função do deslocamento horizontal, no ensaio com o silte inundado, de acordo com a tensão normal aplicada

Figura 4.40: Gráfico do deslocamento vertical em função do deslocamento horizontal, no ensaio com o silte não saturado, de acordo com a tensão normal aplicada e com a sucção do corpo de prova ao final do ensaio

Figura 4.41: Gráfico da tensão cisalhante em função do deslocamento horizontal, no ensaio com o silte não saturado, de acordo com a tensão normal aplicada e com a sucção do corpo de prova ao final do ensaio.

Figura 4.42: Envoltórias de resistência do silte, para os ensaios de cisalhamento direto

Figura 4.43: Tensão desviadora em função da deformação axial específica para os ensaios de compressão simples realizados no solo residual siltoso, realizados com variadas sucções iniciais

Figura 4.44: Sucção em função da deformação axial específica para os ensaios de compressão simples realizados no solo residual siltoso, realizados com variadas sucções iniciais 
Figura 4.45: Tensão desviadora em função da sucção do corpo de prova para os ensaios de compressão simples realizados no solo residual siltoso

Figura 4.46: Envoltórias de resistência do silte não saturado, para os ensaios de compressão simples, e envoltória do silte saturado adotada

Figura 4.47: Interpretação dos ensaios de compressão simples realizados no silte não saturado

Figura 4.48: Ajustes do intercepto de coesão com ângulo de atrito constante, para os ensaios de cisalhamento direto e compressão simples não saturados, no silte......126

Figura 4.49: Ensaio de permeabilidade em argamassa

Figura 4.50: Resultados dos ensaios de permeabilidade: corpos de prova 1, 2 e 3127 Figura 4.51: Ensaio Infiltração em Infiltrômetro de duplo-anel com medição de poropressão de água.

Figura 4.52: Secção esquemática da locação dos instrumentos; magnitude e distribuição de poro-pressão de água no terreno antes do início do ensaio de infiltração.

Figura 4.53: Variação da poro-pressão medido antes, durante e após o término do ensaio, no centro dos anéis de infiltração

Figura 4.54: Variação da poro-pressão medido antes, durante e após o término do ensaio, a 1,5 metros de distância (horizontal) do centro dos anéis de infiltração....132 Figura 4.55: Variação da poro-pressão medido antes, durante e após o término do ensaio, a 2,5 metros de distância (horizontal) do centro dos anéis de infiltração....132 Figura 4.56: Variação da poro-pressão medido antes, durante e após o término do ensaio, a 7,5 metros de distância (horizontal) do centro dos anéis de infiltração....133 Figura 4.57: Resultados da análise numérica obtidos em três intervalos de tempo, apresentando a variação dos valores de poro-pressão da água em kPa: a) três horas; b) seis horas e c) sete horas e meia após o início do ensaio

\section{CAPÍTULO 5}

Figura 5.1: Tensímetro inserido em tubo tensiométrico, com proteção em bloco de concreto da extremidade superior do tubo

Figura 5.2: Seção 1 - Diagrama esquemático da posição relativa e arranjo da .....138 
Figura 5.3: Seção 2 - Diagrama esquemático da posição relativa e arranjo da instrumentação de campo, e perfil geotécnico, na porção do talude com vegetação

Figura 5.4: Pluviometria mensal no campo experimental comparada com a média de postos pluviométricos 140

Figura 5.5: Pluviometria diária e acumulada em 5, 14 e 21 dias no campo experimental comparada com precipitações máximas no Posto da Luz. 141

Figura 5.6: Relação entre o nível d'água e a precipitação 142

Figura 5.7: Relação entre o nível d'água e a precipitação acumulada de 20 dias, até 3 dias antes da data.

Figura 5.8: Correlação entre o nível d'água e a precipitação acumulada de 20 dias, até 3 dias antes da data 144

Figura 5.9-A): Série temporal de poro-pressão de água e precipitação na Linha 1 em ambos os revestimentos superficiais na profundidade de $0,5 \mathrm{~m}$

Figura 5.10-B): Série temporal de poro-pressão de água e precipitação na Linha 1 em ambos os revestimentos superficiais na profundidade de $1,5 \mathrm{~m}$

Figura 5.11-C): Série temporal de poro-pressão de água e precipitação na Linha 1 em ambos os revestimentos superficiais nas profundidades de 3,0 e 4,0 m 148

Figura 5.12-A): Série temporal de poro-pressão de água e precipitação na Linha 2 em ambos os revestimentos superficiais na profundidade de $1,5 \mathrm{~m}$

Figura 5.13-B): Série temporal de poro-pressão de água e precipitação na Linha 2 em ambos os revestimentos superficiais na profundidade de 3,0 $\mathrm{m}$ 149 Figura 5.14-A): Série temporal de poro-pressão de água e precipitação na Linha 3 em ambos os revestimentos superficiais na profundidade de $0,5 \mathrm{~m}$

Figura 5.15-B): Série temporal de poro-pressão de água e precipitação na Linha 3 em ambos os revestimentos superficiais na profundidade de $1,5 \mathrm{~m}$ 150

Figura 5.16-C): Série temporal de poro-pressão de água e precipitação na Linha 3 em ambos os revestimentos superficiais na profundidade de 3,0 m

Figura 5.17-A): Série temporal de poro-pressão de água e precipitação na Linha 4 em ambos os revestimentos superficiais na profundidade de $1,5 \mathrm{~m}$

Figura 5.18-B): Série temporal de poro-pressão de água e precipitação na Linha 4 em ambos os revestimentos superficiais na profundidade de $3,0 \mathrm{~m}$ 
Figura 5.19-A): Série temporal de poro-pressão de água e precipitação na Linha 5 em ambos os revestimentos superficiais na profundidade de $0,5 \mathrm{~m}$

Figura 5.20-B): Série temporal de poro-pressão de água e precipitação na Linha 5 em ambos os revestimentos superficiais na profundidade de $1,5 \mathrm{~m}$ 152 Figura 5.21: Perfis de poro-pressão de água durante estiagem de 10 de junho a 26 de julho, em área com solo argiloso e revestimento superficial em vegetação.......154 Figura 5.22: Perfis de poro-pressão de água durante a estiagem de 10 de junho a 26 de julho, em área com solo argiloso e revestimento superficial em argamassa......155 Figura 5. 23: Perfis de poro-pressão de água durante estiagem de 10 de junho a 26 de julho, em área com solo siltoso e revestimento superficial em vegetação 155 Figura 5. 24: Perfis de poro-pressão de água durante a estiagem de 10 de junho a 26 de julho, em área com solo siltoso e revestimento superficial em argamassa ... 156 Figura 5.25: Perfis de poro-pressão de água durante período chuvoso de 18 a 25 de janeiro, em área com solo argiloso e revestimento superficial em vegetação..........161 Figura 5.26: Perfis de poro-pressão de água durante período chuvoso de 18 a 25 de janeiro, em área com solo argiloso e revestimento superficial em argamassa 161 Figura 5.27: Perfis de poro-pressão de água durante período chuvoso de 18 a 25 de janeiro, em área com solo siltoso e revestimento superficial em vegetação .... 162 Figura 5.28: Perfis de poro-pressão de água durante período chuvoso de 18 a 25 de janeiro, em área com solo siltoso e revestimento superficial em argamassa..........162 Figura 5.29: Distribuição de poro-pressões no talude em 20 de Maio ..................... 165 Figura 5.30: Distribuição de poro-pressões no talude em 22 de Julho.....................167 Figura 5.31: Distribuição de poro-pressões no talude em 31 de Agosto ..................169 Figura 5.32: Distribuição de poro-pressões no talude em 1ํ de Fevereiro...............172 Figura 5.33: Distribuição de poro-pressões no talude em 12 de Abril ......................173

Figura 5.34: Distribuição de poro-pressões no talude em 25 de Maio .....................174

\section{CAPÍTULO 6}

Figura 6.1: Distribuição estimada de poro-pressão de água até o nível d'água do terreno no talude, em $1^{\circ}$ de fevereiro 181

Figura 6.2: Distribuição estimada de poro-pressão de água até o nível d'água do terreno no talude, em 31 de agosto. 
Figura 6.3: Resultado da análise de estabilidade na porção do talude com vegetação, em 1ำ de fevereiro de 2005. 185

Figura 6.4: Resultado da análise de estabilidade na porção do talude revestida com argamassa, em $1^{\circ}$ de fevereiro de 2005. 185

Figura 6.5: Resultado da análise de estabilidade na porção do talude com vegetação, em 31 de agosto de 2005. 186

Figura 6.6: Resultado da análise de estabilidade na porção do talude revestida com argamassa, em 31 de agosto de 2005. 186 


\section{LISTA DE TABELAS}

\section{CAPÍTULO 2}

Tabela 2.1: Valores típicos para as variáveis de entrada do Modelo de Green Ampt (RAWLS, 1983) 39

\section{CAPÍTULO 3}

Tabela 3.1: Caracterização do campo experimental .50

Tabela 3.2: Temperaturas máximas e mínimas registradas na Estação da Água Funda localizada na Zona Sul de São Paulo 55

Tabela 3.3: Dados do Posto Pluviométrico da Luz referentes ao período de 100 anos decorridos entre 1904 e 2003 56

Tabela 3.4: Dados do Posto Pluviométrico Jd. Centenário referentes ao período de 20 anos decorridos entre 1973 e 1992 56

Tabela 3.5: Equação IDF (RMSP). .59

\section{CAPÍTULO 4}

Tabela 4.1: Tempo de estabilização das leituras no tensímetro fornecido pelo fabricante 1

Tabela 4.2: Tempo de estabilização das leituras no tensímetro fornecido pelo fabricante 2 . .80

Tabela 4.3: Ensaios de caracterização com amostras dos blocos indeformados 90

Tabela 4.4: Resistência ao cisalhamento do aterro argiloso medida em ensaios de cisalhamento direto inundado e não saturado. 104

Tabela 4.5.: Parâmetros de resistência ao cisalhamento do aterro argiloso não saturado obtidos em ensaios de cisalhamento direto não saturado. 105

Tabela 4.6: Resistência à compressão simples do aterro argiloso, em função das condições de ensaio. 109

Tabela 4.7: Parâmetros de Bishop (1959) e por Fredlund et al. (1978) para ensaios de compressão simples. 
Tabela 4.8: Resistência ao cisalhamento do aterro argiloso medida em ensaios de cisalhamento direto inundado e não saturado.

Tabela 4.9: Parâmetros de resistência ao cisalhamento do aterro argiloso não saturado obtidos em ensaios de cisalhamento direto não saturado.

Tabela 4.10: Resistência à compressão simples do silte, em função das condições de ensaio.

Tabela 4.11: Parâmetros de Bishop (1959) e por Fredlund et al. (1978) para ensaios de compressão simples 123

\section{CAPÍTULO 5}

Tabela 5.1: Posição relativa dos tensiômetros em relação aos solos existentes no talude 139

Tabela 5.2: Características hidráulicas dos materiais onde ocorre fluxo em $\mathrm{cm} / \mathrm{s}$

Tabela 5.3: Redução de poro-pressão de água durante estiagem entre os dias 10 e 26 de junho.

Tabela 5.4: Poro-pressão de água no início e ao final da estiagem, em kPa.

Tabela 5.5: Coeficientes de permeabilidade no início e ao final da estiagem, em $\mathrm{cm} / \mathrm{s}$

Tabela 5.6: Elevação de poro-pressão de água durante período chuvoso, em kPa 163

Tabela 5.7: Poro-pressões de água durante período chuvoso, em $\mathrm{kPa}$. 163

Tabela 5.8: Três datas com maiores e menores poro-pressões de água médias ... 164 Tabela 5.9: Poro-pressões mínimas e precipitação acumulada de 28 dias nos três

Tabela 5.10: Resumo das conclusões sobre o monitoramento do talude experimental, com indicação dos tipos de revestimento e solo que apresentaram menor poro-pressão de água

\section{CAPÍTULO 6}

Tabela 6.1: Parâmetros de resistência dos solos existentes no talude experimental 
Tabela 6.2: Comparação dos fatores de segurança do talude monitorado, que indica o efeito das variações sazonais de poro-pressão de água na estabilidade do talude

Tabela 6.3: Comparação dos fatores de segurança do talude monitorado, em $1^{\circ}$ de fevereiro, que indica o efeito do revestimento superficial na estabilidade do talude 188

Tabela 6.4: Comparação dos fatores de segurança do talude monitorado, em 31 de agosto, que indica o efeito do revestimento superficial na estabilidade do talude .189 


\section{INTRODUÇÃO}

A ocupação desordenada de áreas públicas nas grandes cidades, principalmente em forma de favelas, e a construção de rodovias, ferrovias, duto-vias e linhas de transmissão em terrenos de elevada declividade levam à ocorrência de situações de risco associado a escorregamentos. A ruptura de um talude nestas situações, em geral, causa danos materiais, perda de vidas e a interdição de vias de acesso e transporte.

Levantamento realizado no site de reportagens www.estadao.com.br referente ao período em que foi realizado este trabalho (2005 a 2007) indicou que foram noticiados em todo o Brasil 210 escorregamentos em bairros populares de cidades médias e grandes, e em rodovias. As reportagens pesquisadas divulgaram que as rupturas de taludes causaram 92 vítimas fatais, 45 vítimas em estado grave, 98 residências destruídas, 1.600 pessoas desabrigadas, oito rodovias interditadas temporariamente, onze rodovias parcialmente interditadas e um túnel interditado. Verifica-se que são grandes os desafios para os engenheiros geotécnicos no que concerne à prevenção e remediação de escorregamentos.

Nos últimos anos, estudos acadêmicos têm ampliado o conhecimento sobre o comportamento dos solos em condições não saturadas. Esses solos são muito comuns nas encostas brasileiras e seu estudo pode levar a inovações na área de prevenção de escorregamentos. A poro-pressão de água tem significativa influência na estabilidade de taludes em solo não saturado.

Estudos científicos estabeleceram uma relação entre a infiltração de águas de chuva e a deflagração de escorregamentos por meio da redução da sucção e pela elevação da poro-pressão de água no solo. Esse processo contribui para reduzir a coesão aparente do solo podendo eliminar essa parcela de resistência, restando apenas a resistência devido ao atrito entre os grãos do solo. 
Este trabalho pretende avaliar o efeito do tipo de revestimento superficial na alteração do perfil de poro-pressão de água e conseqüentemente na estabilidade de taludes não saturados. Para isso foi selecionado para esta pesquisa um talude não saturado localizado na Zona Leste da capital Paulista onde ocorreram dois escorregamentos nos últimos dez anos. Uma licença para a realização da pesquisa foi obtida junto à Prefeitura Municipal de São Paulo.

Um trecho do talude experimental foi cercado e dentro dessa área foram definidas porções com revestimentos superficiais diferenciados. Na porção norte da área experimental foi mantido o revestimento existente em capim alto, e na porção sul foi cortada a vegetação e foi aplicada argamassa de cimento e areia.

A área experimental foi instrumentada com tensiômetros, pluviômetro e medidor de nível d'água. O monitoramento do talude foi feito durante o período de janeiro a setembro de 2005. Amostras deformadas e indeformadas de solo foram retiradas do talude experimental e levadas ao laboratório para realização de ensaios.

Os tensiômetros utilizados no monitoramento são compostos por tubos tensiométricos e tensímetro de punção. Esse tipo de tensiômetro dividido em duas peças é de utilização corriqueira na agronomia e pouco utilizado na área da geotecnia. Por esse motivo, o instrumento será descrito neste trabalho, e resultados de ensaios laboratoriais e em campo para conhecimento de seu funcionamento e comparação com outros tipos tensiômetros serão apresentados.

Além do monitoramento de talude foram realizados no campo experimental ensaios de permeabilidade tipo Guelph e ensaio de infiltração em infiltrômetro de duplo-anel com medição de poro-pressão de água.

Este trabalho está estruturado da seguinte maneira: inicia-se com uma revisão bibliográfica sobre conceitos gerais da mecânica dos solos não saturados (curva de retenção, coeficiente de condutividade hidráulica, resistência ao cisalhamento, e comportamento das bolhas de ar oclusas em solo não saturado); segue com um 
aprofundamento sobre as leis, equações, variáveis e modelos que regem os fluxos não saturados; e retoma os principais mecanismos de instabilização de taludes.

No Capitulo 3 é apresentada a descrição do campo experimental: as caracterizações geológico-geotécnica e geomorfológica da área em que se localiza; as caracterizações climática e pluviométrica da Grande São Paulo e da zona leste da capital Paulista; e a descrição da implantação do experimento inclusive descrição dos instrumentos e sua instalação.

No Capitulo 4 são apresentados os resultados e análises dos ensaios laboratoriais e de campo realizados: ensaios para análise do funcionamento dos tensímetros; ensaios de caracterização, permeabilidade, curva de retenção e resistência ao cisalhamento dos solos existentes no campo experimental; ensaios para determinação do coeficiente de permeabilidade da argamassa de revestimento do talude experimental; e ensaio de infiltração em infiltrômetro de duplo anel. No Capitulo 5 são apresentados os resultados e análises do monitoramento do talude experimental.

O Capítulo 6 apresenta análises de estabilidade do talude monitorado nesta pesquisa, com o objetivo de se determinar o efeito do revestimento superficial na estabilidade do talude. Além disso, será analisado o efeito das variações sazonais de poro-pressão de água na estabilidade do talude monitorado. No Capítulo 7 são apresentadas as conclusões deste trabalho e recomendações para futuras pesquisas. 


\section{ASPECTOS TEÓRICOS SOBRE O FLUXO NÃO SATURADO E SUA INFLUÊNCIA NA ESTABILIDADE DE TALUDES}

No presente capítulo é apresentada revisão bibliográfica sobre os principais conceitos relativos a solos não saturados: curva de retenção, coeficiente de condutividade hidráulica e resistência. A seguir são discutidos o fluxo não saturado, as leis que o descrevem, as variáveis que o condicionam e modelos de previsão de infiltração. Por fim são descritos os mecanismos de instabilização de taludes não saturados identificando em que condições os taludes rompem.

\subsection{Conceitos gerais da mecânica dos solos não saturados}

Apresenta-se a seguir uma revisão dos principais conceitos teóricos relativos a solos não saturados: curva de retenção, coeficiente de permeabilidade, resistência ao cisalhamento, e comportamento de bolhas de ar oclusas em solos não saturados.

\subsubsection{Curva de retenção para os solos não saturados}

A curva de retenção é uma representação da capacidade do solo armazenar água. $E$ pode ser definida como a relação entre a quantidade de água existente no interior de uma massa de solo e a sua respectiva sucção. Essa quantidade de água é referida como umidade volumétrica $\left(\theta_{\mathrm{w}}\right)$ ou como grau de saturação (S). Entretanto, na prática da engenharia geotécnica, o termo umidade volumétrica não é usual. Podese quantificar a umidade volumétrica em termos de teor de umidade gravimétrica $(\mathrm{w})$ ou em termos do grau de saturação (S). As Equações (2.1) e (2.2) indicam como essas variáveis $\left(S, \mathrm{w}\right.$ e $\left.\theta_{\mathrm{w}}\right)$ estão vinculadas:

$$
\theta_{\mathrm{w}}=\frac{\mathrm{Se}}{1+\mathrm{e}}=\mathrm{S} \eta
$$




$$
\theta_{\mathrm{w}}=\frac{\gamma_{\mathrm{d}} \mathrm{w}}{\gamma_{\mathrm{w}}}
$$

Onde: $e$ é o índice de vazios; $\gamma_{\mathrm{d}}$ é a densidade seca; $\gamma_{\mathrm{w}}$ é a densidade da água; $\eta$ é a porosidade

Os principais equipamentos ou materiais utilizados para se determinar a curva de retenção são: placa de sucção, placa de pressão, papel filtro e tensiômetro. A placa de sucção geralmente é utilizada para a determinação de sucções entre 1 e $30 \mathrm{kPa}$; a placa de pressão para sucções entre 50 e $300 \mathrm{kPa}$; o papel filtro para sucções maiores que $100 \mathrm{kPa}$ e menores que $10.000 \mathrm{kPa}$; e os tensiômetros têm faixa de variação de leituras de sucção variável conforme o modelo. Os tensímetros de campo utilizados neste trabalho têm faixa de variação de leitura de sucção/poropressão de água positiva de 100/-100 kPa (considerando-se aqui sucção com valor positivo), porém durante as leituras de campo foram registradas leituras de sucção máximas de $65 \mathrm{kPa}$, o que pode indicar que ocorra perda de pressão nessa faixa de sucções. O tensiômetro de alta capacidade utilizado nos ensaios de laboratório deste trabalho têm faixa de variação de leitura de 30 a $500 \mathrm{kPa}$.

A Figura 2.1 apresenta as principais características hidráulicas de um solo: valor de entrada de ar (correspondente à sucção na qual a água presente nos maiores poros do solo começa a sair), umidade volumétrica residual (umidade em que um grande valor de sucção é necessário para remover uma pequena quantidade de água do solo - $\theta r)$ e a umidade volumétrica para o estado saturado ( $\theta \mathrm{s})$.

As linhas pontilhadas traçadas na Figura 2.1 apresentam a proposta de Fredlund e Xing (1994) para a determinação da umidade volumétrica residual e o valor da entrada de ar no solo. De acordo com os autores, este procedimento empírico é bastante valioso para quantificar as principais características da curva. Por esse procedimento, o valor de entrada de ar é caracterizado pela intersecção entre a reta horizontal, que corresponde à umidade volumétrica saturada, com a reta tangente que passa pelo ponto de inflexão da curva. A intersecção da reta tangente que 
passa pelo ponto de inflexão com a reta que representa aproximadamente a curva para altos valores de sucção, determina o valor da umidade volumétrica residual. Os autores citados apontam que a umidade volumétrica nula parece ser essencialmente a mesma para todos os tipos de solos. De acordo com Croney e Coleman (1961), esse valor de sucção é ligeiramente menor que $10^{6} \mathrm{kPa}$. Estão apresentadas também na Figura 2.1 as curvas de retenção obtidas pelo caminho da secagem (curva cheia) e pelo caminho de umedecimento (tracejada). A diferença de comportamento dessas duas curvas é chamada de histerese.

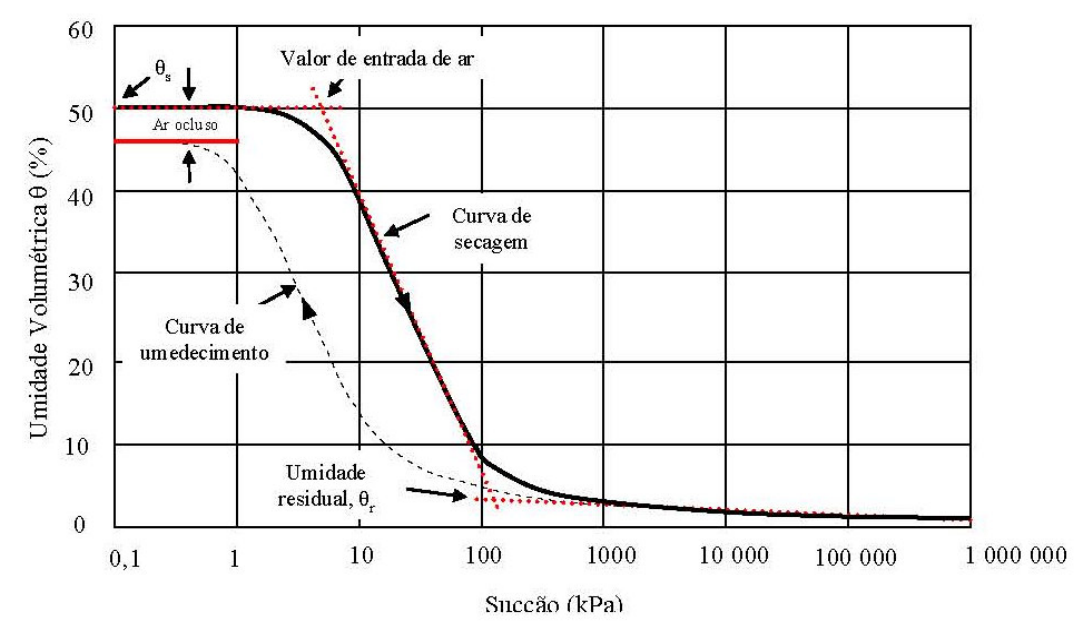

Figura 2.1: Curva de retenção com principais características hidráulicas de um solo

\subsubsection{Coeficiente de condutividade hidráulica para os solos não saturados}

A condutividade hidráulica do solo é uma medida de sua capacidade de transportar água. Solos não saturados apresentam coeficientes de condutividade hidráulica variáveis em função da umidade volumétrica ou da sucção do solo. Solos mais úmidos apresentam menor sucção conforme pode ser observado na Figura 2.1. No sentido inverso solos mais secos apresentam maior sucção e, portanto, menor coeficiente de permeabilidade, conforme pode ser observado na Figura 2.2. 


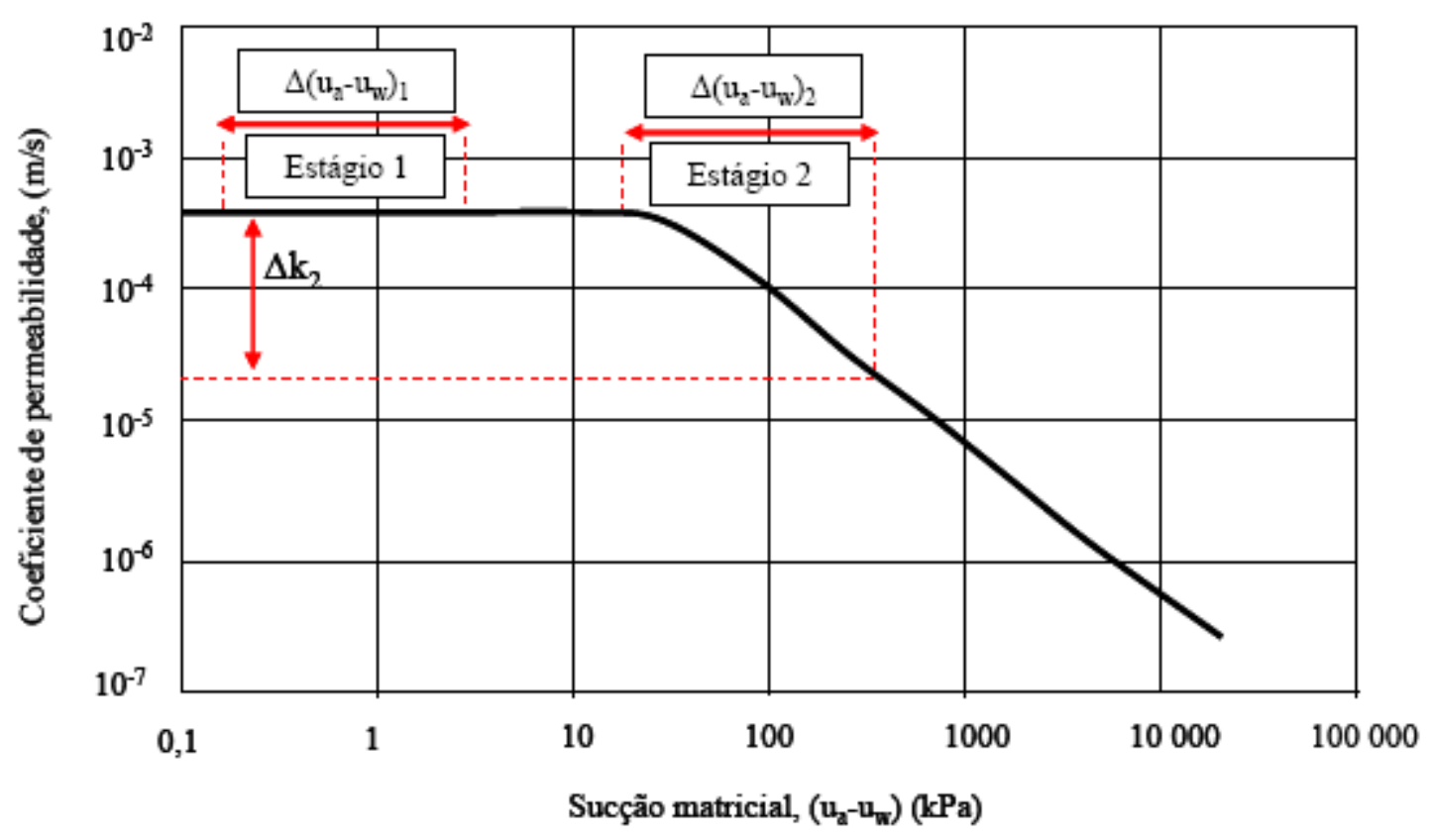

Figura 2.2: Variação do coeficiente de permeabilidade com a sucção

Observa-se na Figura 2.2 também, que o coeficiente de condutividade hidráulica mantém-se constante até um determinado valor de sucção. Esse valor é igual ao valor de entrada de ar do solo. A partir dessa sucção ocorre entrada de ar no solo e, portanto sua umidade volumétrica e coeficiente de condutividade hidráulica decrescem.

A determinação da variação do coeficiente de condutividade hidráulica com a sucção, ou simplesmente função permeabilidade, pode ser feita direta ou indiretamente. As técnicas diretas são realizadas em campo ou em ensaios de laboratório, e apresentam as seguintes dificuldades: longo tempo requerido, necessidade de medidas acuradas do volume de água infiltrada, para sucções elevadas a amostra se retrai e pode se separar das paredes do permeâmetro ou da pedra porosa interrompendo o fluxo d'água.

O uso de técnicas indiretas se faz a partir da curva de retenção, sendo necessário também o uso do coeficiente de permeabilidade saturado, a partir dos quais se faz 
um tratamento estatístico para a determinação da relação entre o coeficiente de permeabilidade e a sucção atuante.

Leong e Rahardjo (1997) apresentam uma explanação sobre os três tipos de determinação da função permeabilidade usualmente empregados: funções empíricas, modelos macroscópicos e modelos estatísticos, apresentando nessa ordem um grau crescente de sofisticação, sendo os modelos estatísticos os mais rigorosos.

Os modelos estatísticos se baseiam na hipótese de que tanto a função permeabilidade quanto a curva de retenção são funções da distribuição dos tamanhos dos poros de um solo (Fredlund et al. 1994). Childs e Collis-George (1950) apud Fredlund et al. (1994) apresentaram provavelmente a primeira proposta de se prever a função permeabilidade baseada na distribuição dos tamanhos dos poros de um solo. Fredlund et al. (1994) aperfeiçoaram a proposta daqueles autores e apresentaram um modelo, representado pela Equação (2.3), para determinar a função permeabilidade. Para se aplicar essa equação é necessário primeiramente determinar uma função que represente a curva de retenção do solo.

$$
\mathrm{K}_{\mathrm{r}}=\frac{\int_{\ln (\psi)}^{\mathrm{b}} \frac{\theta\left(\mathrm{e}^{\mathrm{y}}\right)-\theta(\psi)}{\mathrm{e}^{\mathrm{y}}} \theta^{\prime}\left(\mathrm{e}^{\mathrm{y}}\right) \mathrm{dy}}{\int_{\ln \left(\psi_{\mathrm{b}}\right)}^{\mathrm{b}} \frac{\theta\left(\mathrm{e}^{\mathrm{y}}\right)-\theta_{\mathrm{s}}}{\mathrm{e}^{\mathrm{y}}} \theta^{\prime}\left(\mathrm{e}^{\mathrm{y}}\right) \mathrm{dy}}
$$

Onde: $K_{\mathrm{r}}$ é a permeabilidade relativa em $\mathrm{cm} / \mathrm{s}$; $\psi$ é a sucção em $\mathrm{kPa} ; \psi_{\mathrm{b}}$ é a sucção de entrada de ar em $\mathrm{kPa}$; b corresponde ao valor de ln (106); y é a variável de integração que representa o logaritmo da sucção; e $\theta^{\prime}$ é a primeira derivada da equação da curva de retenção proposta por Fredlund e Xing (1994).

Van Genuchten (1980) propôs equações para prever a função condutividade hidráulica de solos não saturados baseadas em modelo desenvolvido por Mualem (1976), que também se fundamenta na distribuição dos tamanhos dos poros. As Equações (2.4) a (2.7) propostas por Van Genuchten (1980), e utilizadas neste 
trabalho para a determinação da função permeabilidade, são função da variável adimensional umidade volumétrica normalizada, calculada pela Equação (2.8), e das variáveis $m, n, \alpha$. Sendo as três últimas propostas por van Genuchten para ajustar a curva de retenção do solo aos dados obtidos experimentalmente.

$$
\begin{gathered}
K_{r}(\Theta)=\Theta^{1 / 2}\left[1-\left(1-\Theta^{1 / m}\right)^{m}\right]^{2} \\
\text { para } m=1-1 / n \text { e } \\
K_{r}(\Theta)=\Theta^{2}\left[1-\left(1-\Theta^{1 / m}\right)^{m}\right] \\
\text { para } m=1-2 / n
\end{gathered}
$$

Onde $\Theta=$ umidade volumétrica normalizada $=\frac{\theta-\theta_{\mathrm{r}}}{\theta_{\mathrm{s}}-\theta}$

\subsubsection{Resistência ao cisalhamento dos solos não saturados}

Bishop (1959) apresentou uma expressão para representar a tensão efetiva em um solo que levasse em conta o grau de saturação do solo. O parâmetro proposto pelo autor para indicar a variação do grau de saturação foi o parâmetro $\chi$ que varia de 0 a 1 indicando solo com grau de saturação igual a 0 e igual a 1 , respectivamente.

Substituindo-se a equação proposta por Bishop (1959) na equação proposta por Terzaghi (1936) que fornece a resistência ao cisalhamento de solos saturados (critério Mohr-Coulomb) obtém-se a Equação (2.9) que fornece a resistência ao cisalhamento de solos não saturados, proposta por Bishop (1959):

$$
\tau=c^{\prime}+\left\{\left(\sigma-u_{a}\right)+\chi\left(u_{a}-u_{w}\right)\right\} \operatorname{tg} \phi^{\prime}
$$

Onde: $u_{\mathrm{a}}$ é a poro-pressão de ar no solo, $\mathrm{u}_{\mathrm{w}}$ é a poro-pressão de água no solo e $\chi$ é o parâmetro proposto por Bishop relacionado com o grau de saturação do solo. 
Skempton (1960) interpretou o valor de $\chi$ na equação apresentada por Bishop (1959) assumindo a hipótese de que esse parâmetro represente uma parcela da área total do solo. Para um solo não saturado, Skempton (1960) considera que a poro-pressão de água atua sobre uma área $\chi$ por unidade de área do solo, e que a poro-pressão de ar atua em uma área $(1-\chi)$. Quando o solo está saturado, os vazios do solo estão preenchidos por água e o parâmetro $\chi$ se aproxima de 1. Para o solo seco, os vazios estão preenchidos com ar e o valor de $\chi$ é muito pequeno.

Segundo Fredlund (1979), diferentemente dos solos saturados, cujo comportamento é diretamente proporcional a uma variável de estado de tensão $\left(\sigma-u_{w}\right)$, os solos não saturados têm comportamento que pode ser expresso segundo três combinações de variáveis de estado de tensão, cujas variáveis de estado de tensão são: $\left(\sigma-u_{w}\right)$, ( $\sigma$ $\left.u_{a}\right),\left(u_{a}-u_{w}\right)$. A combinação utilizando-se as variáveis $\left(\sigma-u_{a}\right)$ e $\left(u_{a}-u_{w}\right)$ foi escolhida por Fredlund (1979) para representar a resistência de solos não saturados pois ela permite representar os efeitos da mudança da pressão normal total sobre o solo separadamente dos efeitos causados pela mudança da poro-pressão da água no solo. A Equação (2.10) representa a proposta de Fredlund et al. (1978) para a resistência de solos não saturados:

$$
\tau=c^{\prime}+\left(\sigma-u_{a}\right) \operatorname{tg} \phi^{\prime}+\left(u_{a}-u_{w}\right) \operatorname{tg} \phi^{b}
$$

Onde: $\phi^{b}$ é o ângulo que indica a razão de aumento da resistência ao cisalhamento em função do aumento da sucção.

Analisando-se a Equação (2.10) percebe-se novamente que se trata de uma extensão da equação apresentada por Terzaghi (1936) para solos saturados. Quando o solo está saturado, a poro-pressão de água se aproxima da poro-pressão de ar, e dessa maneira, a sucção tende a zero anulando a terceira parcela do lado direito da equação, revertendo a equação proposta por Fredlund et al. (1978) na proposta por Terzaghi (1936). A equação proposta por Fredlund et al. (1978) pode ser representada por um gráfico em três dimensões, conforme apresentado na Figura 2.3. Na ordenada é apresentada a tensão cisalhante, e nas abscissas são apresentadas as variáveis: tensão normal total e a sucção. 


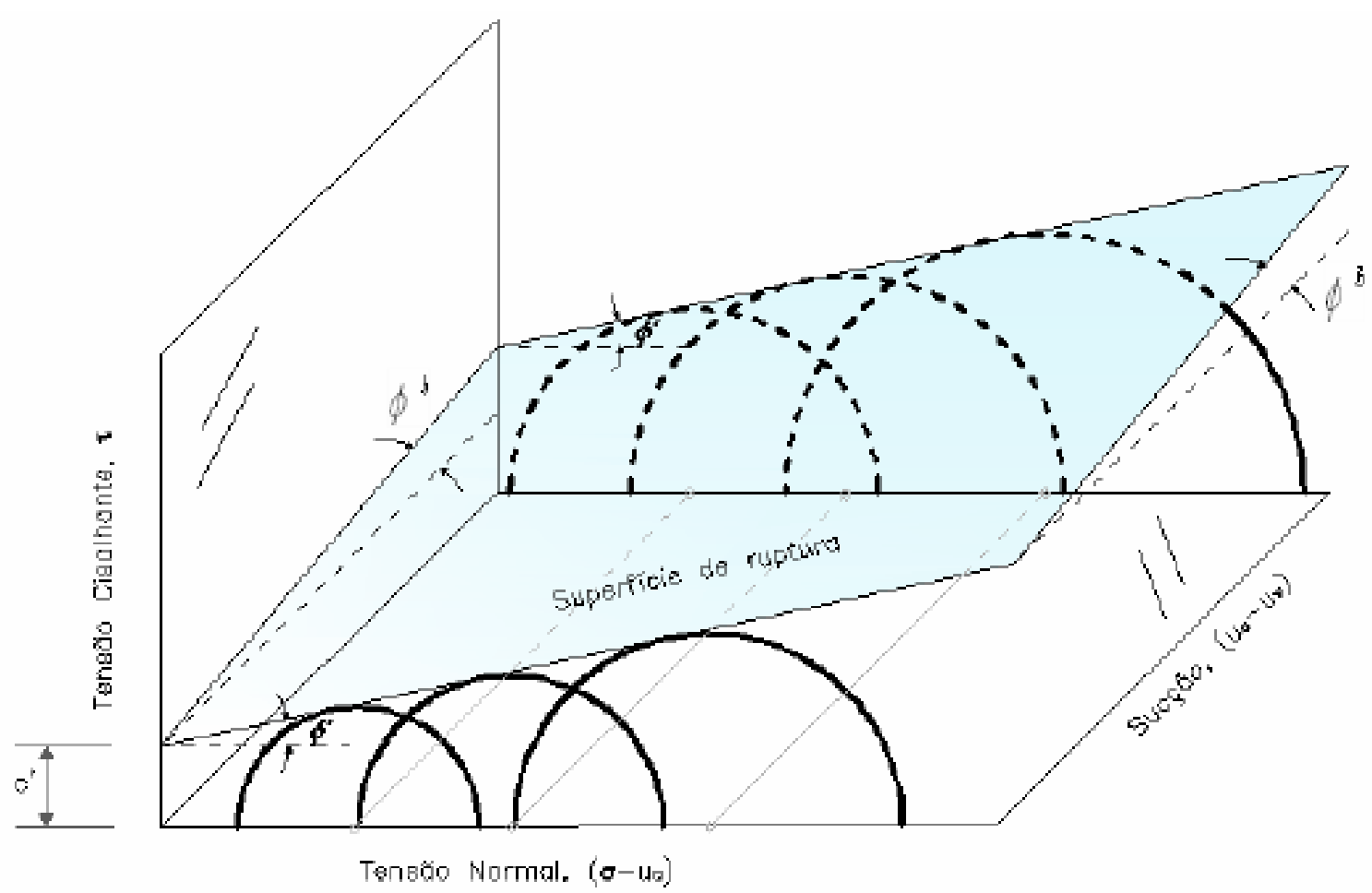

Figura 2.3: Superfície de ruptura para um solo não saturado, conforme equação proposta por Fredlund et al. (1978).

Conforme pode ser observado na Figura 2.3, o aumento da resistência cisalhante devido ao aumento na tensão normal é caracterizado pelo ângulo de atrito efetivo. Por outro lado, o ganho da resistência cisalhante devido ao aumento da sucção é caracterizado pelo ângulo de atrito $\phi^{b}$.

A superfície formada pelos pontos em que ocorre de ruptura, idealizada por Fredlund et al. (1978) e representada pela Equação (2.10) tem forma plana, ou seja, os valor de $\phi^{\prime}$ e $\phi^{b}$ são constantes. De fato, resultados experimentais apresentados por diversos autores, entre eles Abramento (1988), Futai et al (2004), Futai et al (2006) e Vilar (2006), indicaram que o aumento da resistência devido ao aumento da sucção não é necessariamente constante, variando em função do nível de sucção do solo.

De acordo com Vanapalli et al. (1996) a razão pela qual ocorre variação na resistência ao cisalhamento de um solo não saturado quando se muda o nível sucção do solo, parece estar correlacionada com a área dos meniscos de água em 
contato com as partículas sólidas. Dessa maneira, é evidente a existência de uma correlação entre a curva de retenção e a resistência ao cisalhamento de um solo não saturado. Vanapalli et al. (1996), baseados no modelo físico apresentado por White et al. (1970), diferenciam três fases no processo de dessaturação: a primeira fase chamada de estágio ou zona de efeitos de contorno; a segunda fase chamada de estágio ou zona de dessaturação; e a terceira e última fase chamada de zona residual, de dessaturação. Na Figura 2.4 (a) está representada a curva de retenção dividida em três estágios ou zonas conforme propostos por Vanapalli et al. (1996); e na Figura 2.4 (b) é indicada a variação da resistência ao cisalhamento com a variação da suç̧ão.

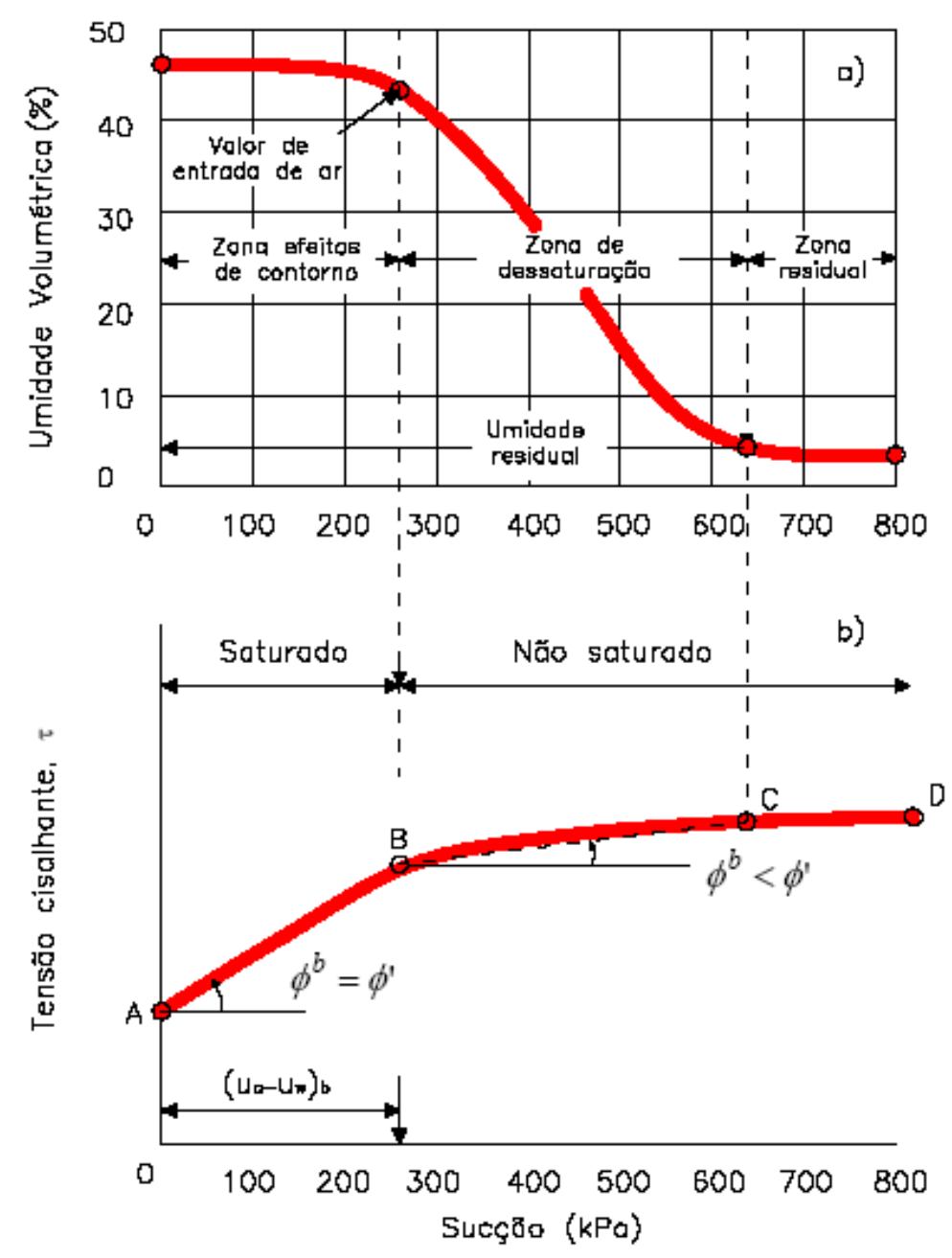

Figura 2.4: Relação entre a curva de retenção e a resistência ao cisalhamento de um solo não saturado: (a) curva de retenção, e (b) envoltória não linear da resistência, Vanapalli et al. (1996). 
A primeira fase, chamada de estágio de efeitos de contorno, é caracterizada por poros preenchidos completamente com água (solo saturado). Nessa fase (estágio anterior ao valor de entrada de ar) a resistência ao cisalhamento aumenta de forma linear com o aumento da sucção (reta AB da Fig.2.4 b). A segunda fase ou estágio de dessaturação inicia-se a partir do valor de entrada de ar do solo até o valor da umidade residual. Nesse estágio, os meniscos de água existentes no interior do solo estão isolados, e, ao longo dessa fase, a resistência ao cisalhamento cresce de forma não linear, representado pelo trecho BC da Figura 2.4 (b). Na zona residual de dessaturação é necessário um aumento elevado da sucção para se reduzir uma pequena quantidade de água no solo. A partir da umidade residual a resistência cisalhante pode aumentar, diminuir ou permanecer constante (trecho CD).

Em solos que dessaturam relativamente rápido, tais como areias e siltes, pode-se esperar que a resistência diminua na zona residual. De acordo com Vanapalli et. al. (1996) isso ocorre porque na condição de sucção residual, a pequena quantidade de água existente nos poros desses solos não é capaz de transmitir para as partículas o aumento de resistência ao cisalhamento provocado pelo aumento da sucção, quando da perda de água. Já em solos como as argilas, na zona residual, uma quantidade relativamente alta de água pode existir nos poros entre os agregados, na forma de água adsorvida, e, quando da perda de água pelo solo, ocorre elevação da sucção que é transmitida para a água adsorvida, provocando aumento da resistência ao cisalhamento do solo mesmo na zona residual.

Vanapalli et al. (1996) e Fredlund et al. (1996) propuseram a Equação (2.11) para representar a resistência ao cisalhamento de solos não saturados que leva em conta as observações de diversos autores de que: (a) a resistência ao cisalhamento dos solos não saturados varia quando muda-se o nível sucção do solo; e (b) que essa variação parece estar correlacionada com a área dos meniscos de água em contato com as partículas sólidas.

$$
\tau=c^{\prime}+\left(\sigma_{n}-u_{a}\right) \operatorname{tg} \phi^{\prime}+\left(u_{a}-u_{w}\right)\left(\Theta^{\mathrm{K}}\right)\left(\operatorname{tg} \phi^{\prime}\right)
$$

Onde: $\Theta=$ umidade volumétrica normalizada $=\frac{\theta-\theta_{\mathrm{r}}}{\theta_{\mathrm{s}-\theta_{\mathrm{r}}}} ; \mathrm{K}=$ parâmetros obtidos experimentalmente 
Correlacionando-se a Equação (2.9) proposta por Bishop (1959) e a Equação (2.11) proposta por Vanapalli et al. (1996) e Fredlund et al. (1996) para representar a resistência ao cisalhamento dos solos não saturados, pode-se relacionar os parâmetros $\chi$ e K pela Equação (2.12):

$$
\chi=(\Theta)^{\mathrm{K}}
$$

\subsubsection{Comportamento das bolhas de ar oclusas em solos não saturados}

Em ensaios de laboratório sob condições não drenadas, o ar pode tornar-se rarefeito, indicando uma pressão negativa (abaixo da atmosférica), ou ficar comprimido, gerando uma pressão positiva, conforme pode ser visto na Figura 2.5 apresentada em Fredlund e Rahardyo (1993).

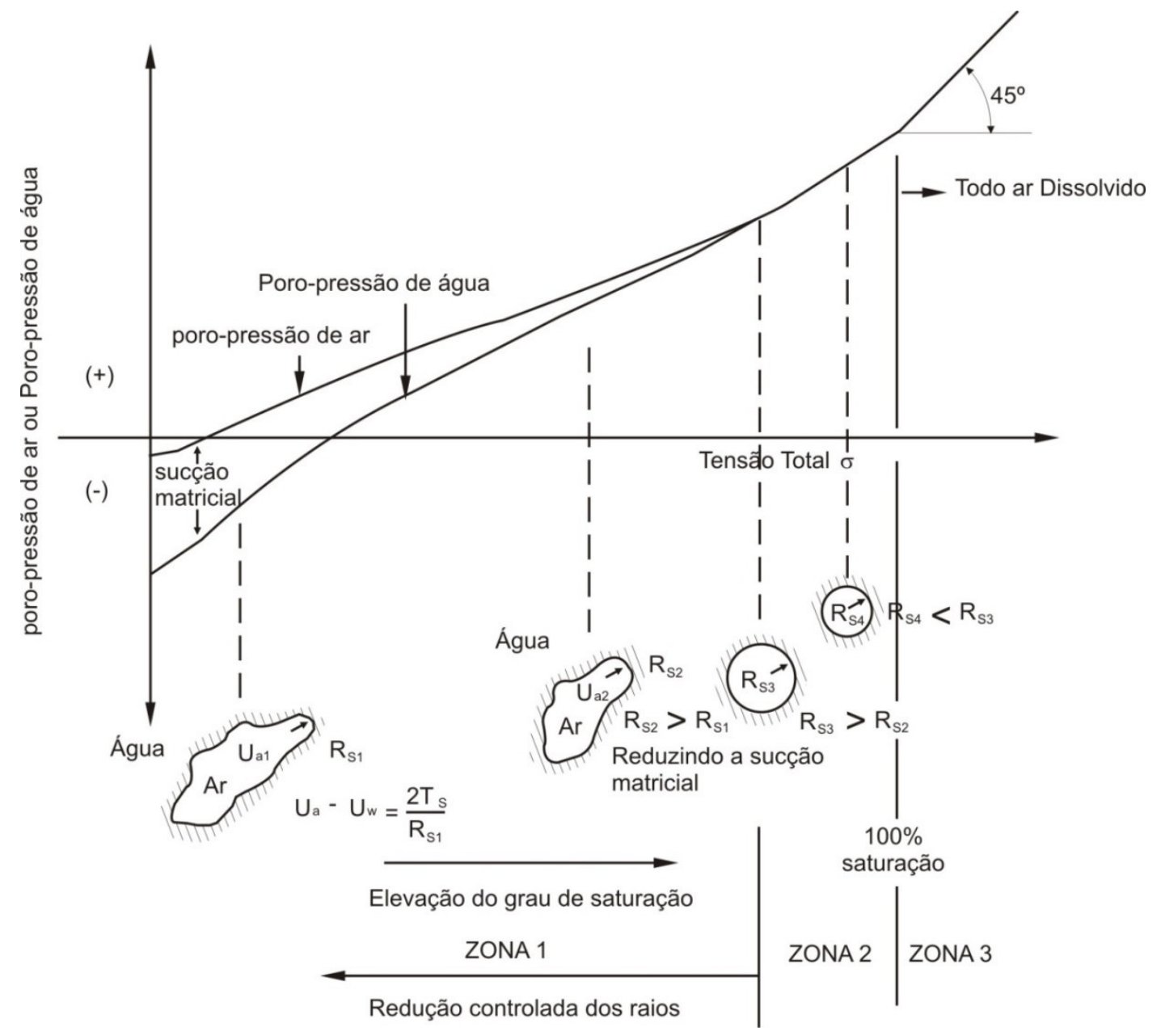

Figura 2.5: Variação das poro-pressões de água e ar devido a alterações na tensão total durante ensaio de compressão não-drenada 
Devido à existência da tensão capilar, a interface ar-água está sempre sujeita a uma pressão que é função dos diversos raios de curvatura que a bolha de ar tem em diferentes pontos de contato com a água e das tensões capilares nesses pontos, conforme indicado na ZONA 1 da Figura 2.5. Nesse contexto é importante seguir o raciocínio de Vaugham (1990):

Em solos não-saturados, o ar e a água, ocorrem em pressões diferentes, devido à capilaridade. Duas distribuições do ar podem existir: ar como uma fase fluida contínua, quando a permeabilidade do solo ao ar é muito elevada; e ar ocluso, quando $\mathrm{o}$ ar ocorre somente como bolhas isoladas e a permeabilidade do solo ao ar é baixa, porque o fluxo de ar só ocorre por difusão. A sucção $\left(u_{a}-u_{w}\right)$ é pequena quando a poro-pressão de água é maior que $100 \mathrm{kPa}$. Entretanto, a diferença é grande quando a pressão na água é sub-atmosférica.

Há uma aparente anomalia entre essas observações e a tendência prevista, se considerarmos bolhas de ar em água livre. Nesse caso, as bolhas devem comprimir se a pressão na água crescer, o raio capilar diminuir, e a diferença entre as pressões ar-água crescer. No entanto, as bolhas de ar em um aterro compactado (situação de compressão não drenada) não estão em água livre, e sim, confinadas dentro da estrutura do solo. Todos os meniscos da mesma bolha têm o mesmo raio, que é controlado pela forma como o menisco se retrai nos interstícios entre as partículas, e não pelo tamanho da bolha de ar.

Considere-se agora uma situação transitória de uma bolha $A$, de menor tamanho que uma bolha $B$. A bolha $A$ pode se tornar esférica devido a um aumento da pressão da água e a diferença de pressão $\left(u_{\mathrm{a}}-\mathrm{u}_{\mathrm{w}}\right)$ tende a crescer. À proporção que a pressão aumenta, a dissolução do ar na água (regida pela Lei de Henry) aumenta, o diâmetro da bolha A fica ainda menor, gerando nova dissolução na água, até o momento em que ela desaparece.

$\mathrm{O}$ ar dissolvido na água irá circular pelo solo, até encontrar um vazio maior, Bolha B. Como a pressão cai porque $\left(\mathrm{u}_{\mathrm{a}}-\mathrm{u}_{\mathrm{w}}\right)$ é menor, o ar pode voltar à fase gasosa, incorporando-se à Bolha B. Por esse processo, conhecido como difusão, todo o ar 
tenderá a ocupar os maiores vazios. Duas conclusões podem ser tiradas dessa análise:

- O grau de saturação do solo é dado aproximadamente pelo volume total de vazios menores do que aqueles contendo a bolha $\mathrm{B}$, dividido pelo volume total de vazios.

- A diferença de pressão $\left(\mathrm{U}_{\mathrm{a}}-\mathrm{U}_{\mathrm{w}}\right)$ é dada pelo raio capilar da bolha $\mathrm{B}$, que é aproximadamente igual ao raio do poro que contém a bolha $B$.

O texto de Vaugham (1990) acima transcrito permite à constatação, elaborada por Cruz (1996), de alguns fatores relevantes:

(a) quando o ar ocorrer na forma oclusa, ele terá uma tendência a ocupar os maiores vazios, havendo uma transferência do ar por difusão;

(b) a diferença de pressão ar-água tende a diminuir com o aumento da pressão da água, conforme pode ser visto na Figura 2.5;

(c) o tamanho da bolha de ar no solo é dado prioritariamente pela dimensão dos vazios, e secundariamente pelo estado de tensões. Significa que um solo com vazios menores e um dado grau de saturação terá bolhas menores, e em maior quantidade do que outro solo com vazios maiores e mesmo grau de saturação.

\subsection{Fluxo em solos não saturados}

O fluxo de água para o interior de um solo não saturado resulta na diminuição da sucção, na redução da tensão efetiva no solo e aumento de seu volume, ou a um inchamento. Portanto o fluxo não saturado provoca alterações nas principais características do solo, como resistência, índice de vazios e permeabilidade, segundo Fredlund e Rahardyo (1993). 
Há inúmeras situações em que o fluxo de água é predominantemente unidimensional. Consideremos uma superfície de terreno coberta, com nível d'água localizado a uma determinada profundidade, e com uma cobertura impedindo qualquer fluxo vertical de água a partir da superfície do terreno, conforme mostrado na Figura 2.6 (Fredlund e Rahardyo 1993).

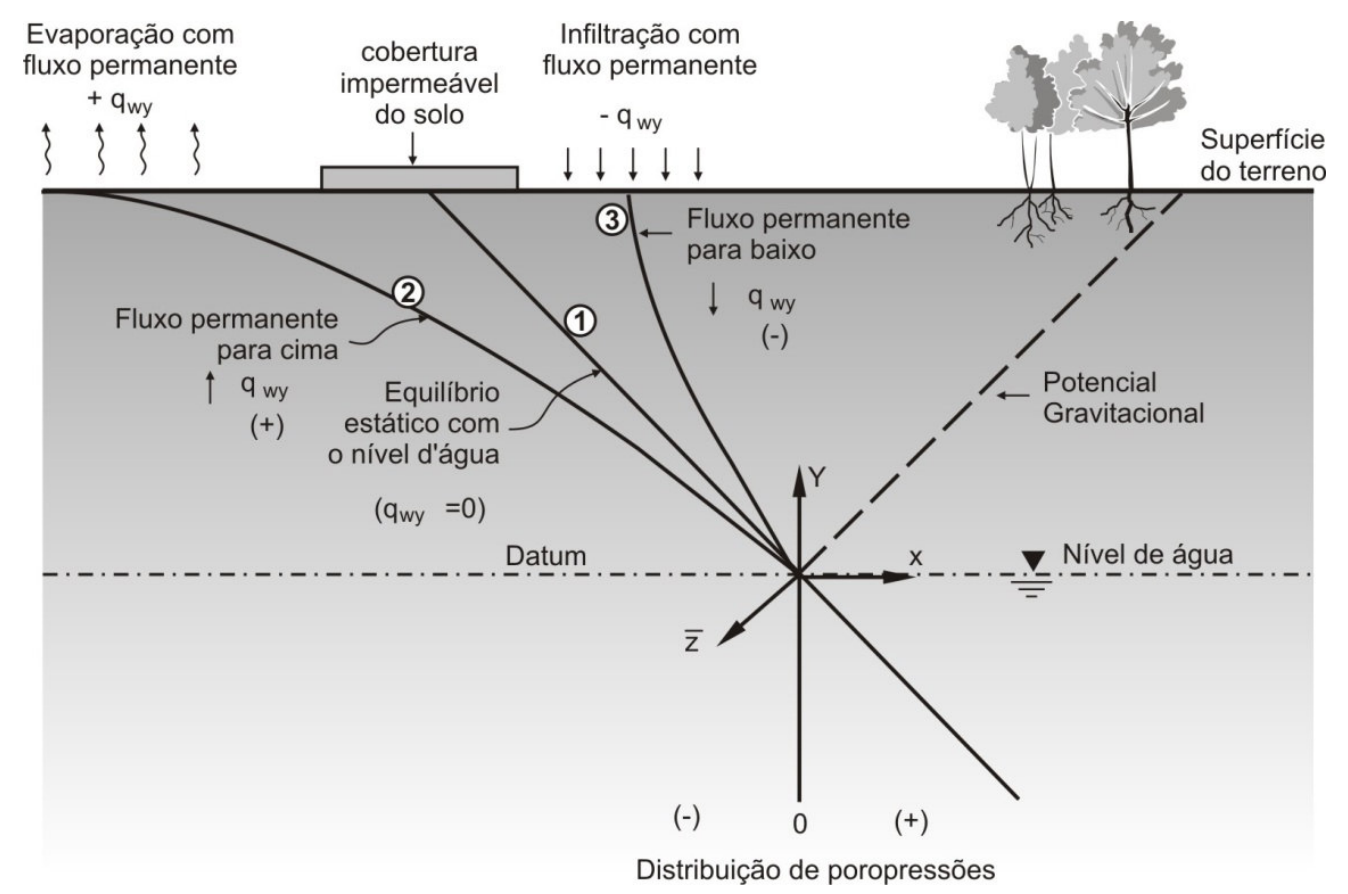

Figura 2.6: Condições de equilíbrio estático e fluxo contínuo na zona de poropressões de água negativas

Considere-se as poro-pressões de água como negativas e em condição de equilíbrio estático com respeito ao nível freático. Os potenciais de poro-pressão de água têm distribuição linear com a profundidade (linha 1 da Figura 2.6). Se a cobertura fosse removida o terreno estaria exposto ao ambiente. Mudanças no ambiente poderiam produzir fluxos na direção vertical alterando o perfil de poro-pressão de água. Um fluxo contínuo de evaporação causaria diminuição das poro-pressões de água, tornando-as ainda mais negativas (linha 2 da Figura 2.6). E um fluxo contínuo de infiltração para o interior do maciço causaria elevação das poro-pressões de água, tornando-as menos negativas (linha 3 da Figura 2.6). 


\subsubsection{Lei de Darcy}

A Lei de Darcy relaciona a taxa de fluxo de água em solo saturado com o gradiente de potencial hidráulico, usando a propriedade do solo chamada coeficiente de permeabilidade, $\mathrm{k}_{\mathrm{s}}$, conforme indica a Equação (2.13):

$$
v_{s}=K_{s} \frac{\delta h_{w}}{\delta y}
$$

Onde: $v_{s}=$ velocidade do fluxo de água; $K_{S}=$ coeficiente de permeabilidade saturado; $\mathrm{e}$ $\delta h_{w} / \delta y=i=$ gradiente de potencial hidráulico na direção vertical y

Existem evidências empíricas de que a Lei de Darcy é válida também para o fluxo não saturado (Buckingham, 1907; Richard, 1931; Childs \& Collis-george, 1950) desde que o coeficiente de permeabilidade possa ser assumido como sendo uma função da umidade volumétrica, conforme indica a Equação (2.14):

$$
v_{s}=-K_{w}(\theta) \frac{\delta h_{w}}{\delta y}
$$

Onde: $\mathrm{K}_{\mathrm{w}}(\theta)=$ coeficientede permeabilidade função da umidade volumétrica $\theta$

Considerando que o fluxo não saturado é gerado pelo gradiente de potencial hidráulico e que este fornece a energia necessária para que ocorra movimentação de água no solo, descrevem-se a seguir as parcelas que compõem o potencial hidráulico: (a) potencial de pressão (ou matricial) devido a poro-pressão de água no solo; (b) potencial gravitacional associado às forças de atração gravitacionais; (c) potencial osmótico devido à concentração de solutos na água intersticial; (d) potencial térmico devido a diferenças de temperatura no solo; (e) potencial de velocidade; e (f) potencial aplicado por raízes de vegetação. 
O potencial de pressão é devido a forças de retenção de água na matriz ou esqueleto do solo, também denominado potencial matricial, e é composto por forças capilares resultantes dos meniscos entre a água e o ar presentes nos poros do solo, e composto também por forças de adsorção devidas à interação entre a água adsorvida e partículas coloidais do solo. Dependendo de sua granulometria, uma ou outra força se sobrepõe. Nos solos granulares como areia e silte as forças capilares são mais importantes, e em solos finos como argila e turfa as forças de adsorção são mais relevantes.

O potencial gravitacional é associado a forças de atração gravitacionais que tendem a deslocar a água na direção vertical para baixo, em oposição ao potencial matricial, de retenção da água intersticial.

Gradientes osmóticos assumem papel fundamental no fluxo de líquidos que apresentam diferentes concentrações de solutos no interior do maciço. No caso de infiltração de águas de chuva em solos não saturados, pode-se admitir que gradientes osmóticos tendam a produzir efeitos de segunda ordem de importância, pois a concentração de solutos na água intersticial não apresenta grandes diferenças em relação àquela presente na superfície do terreno, geralmente proveniente das águas de chuva.

O fluxo de água no interior do solo não saturado pode ocorrer tanto na fase líquida como na fase gasosa (vapor d’água) devido a gradientes de potencial pneumáticos decorrentes de potenciais térmicos, ou seja, diferenças de temperatura entre a superfície do terreno e o interior do maciço provocam variações de pressão no ar/vapor d'água que por sua vez geram fluxo dessa mistura de gases.

Os solos relativamente secos, sob gradientes térmicos importantes encontram-se sujeitos a gradientes de potencial térmico que podem ser responsáveis por expressivo fluxo de vapor d'água no solo. Pode-se admitir que gradientes de potencial térmico sejam desprezíveis nos casos em que o solo apresente níveis de umidade elevados, situação que ocorre nos períodos chuvosos do ano. Nos períodos de estiagem as poro-pressões de água tendem a diminuir por efeito do 
gradiente de potencial gravitacional, e a porção de água oclusa nas camadas superficiais tende a passar para o estado gasoso, evaporação, e a fluir para fora do maciço por meio de gradientes de potencial térmico.

O potencial de velocidade é função da diferença entre as velocidades da água entre dois pontos analisados, e pode ser desconsiderado devido à baixa energia envolvida neste potencial. O potencial aplicado pelas raízes da vegetação é tão maior quanto o porte da vegetação, e varia durante o ano em função dos períodos de crescimento da vegetação.

O potencial hidráulico do solo pode ser expresso pela Equação (2.15).

$$
h_{w}=h_{p}+h_{g}+h_{o}+h_{t}+h_{v}+h_{r}
$$

Onde: $h_{w}=$ potencial hidráulico

$h_{p}=$ potencial de pressão

$h_{g}=$ potencial gravitacional

$h_{o}=$ potencial osmótico

$h_{t}=$ potencial térmico

$h_{r}=$ potencial aplicado pelas raízes da vegetação

$h_{v}=$ potencial de de velocidade da água

Considerando que:

(a) o gradiente de potencial osmótico pode ser desconsiderado pela pequena diferença de concentração de sais entre a água existente no interior de solos não saturados, e não contaminados com produtos químicos, e a água de chuva isenta de sais;

(b) os gradientes de potencial térmico e de potencial aplicado pelas raízes da vegetação não são relevantes nos períodos de chuvas intensas e portanto para o estudo da instabilização de taludes; 
(c) o potencial de velocidade da água pode ser desconsiderado por ser irrelevante em comparação com os potenciais de pressão e gravitacional;

(d) o potencial de pressão pode ser expresso pelo quociente entre a poropressão de água em um ponto e o peso específico da água;

(e) o potencial gravitacional pode ser expresso em termos de elevação de um determinado ponto em relação a uma cota de referência,

Pode-se reescrever a Equação (2.15) de forma que seja válida para fluxos de umedecimento do solo, ficando igual à Equação de Bernoulli (2.16).

$$
h_{T}=\frac{u_{w}}{\gamma_{w}}+z
$$

Onde: $h_{T}$ é $o$ potencial total; $u_{w}$ é a poropressão de água; $\gamma_{w}$ é o peso específico da água; z é a altura em relação a um plano de referência

Conforme descrito anteriormente, o gradiente de potencial hidráulico representa a energia disponível no sistema que promove o fluxo de água. Em períodos de chuvas intensas, esse gradiente é composto pelos gradientes de potencial de pressão e de potencial gravitacional. Por outro lado, nos períodos secos do ano em que as temperaturas ambiente sejam mais elevadas e que estejam associadas ao crescimento da vegetação, o gradiente de potencial hidráulico deve incluir as parcelas de gradiente de potencial térmico e de potencial aplicado pelas raízes da vegetação. Por falta de parâmetros, não é comum encontra-se estudos que incluam essas duas parcelas na simulação de fluxo não saturado.

As duas situações descritas acima, períodos chuvosos e períodos secos, estão relacionadas ao grau de saturação do solo, isto é, em períodos de chuvas intensas o solo apresenta elevado grau de saturação, maior que cerca de $85 \%$. Nessa situação é comum que $o$ ar intersticial se apresente ocluso pela água presente no solo. E nos 
períodos secos do ano, quando o grau de saturação geralmente é inferior a cerca 85 $\%$, o ar intersticial encontra-se contínuo e conectado ao ambiente externo.

Nessas duas situações os fluxos de ar e de água no solo ocorrem de maneira distinta, influenciados principalmente pela condição do ar intersticial: ocluso em bolhas ou contínuo conectado à pressão atmosférica. Descrevem-se a seguir essas duas situações:

Segundo Cruz (1996) a equação (2.14) é válida para solos não saturados nos quais a fase gasosa é contínua, ou seja, solos com graus de saturação menores que cerca de 85 \%. Nesses casos os vazios são considerados inter-comunicantes, e a poropressão de ar deve ser a mesma em todos os vazios do solo. Como a permeabilidade do solo ao ar é elevada, é de esperar que em condições naturais a pressão do ar seja a atmosférica.

Porém a equação (2.14) não é válida caso o volume de água nos vazios seja suficiente para isolar o ar nos vazios maiores sob a forma de bolhas. Nesse caso, as pressões no ar e na água continuarão a ser diferentes, devido à tensão capilar, porém haverá uma diferença fundamental, a pressão "hidrostática" que passa a atuar nas partículas sólidas é a pressão da água, e não mais a diferença de entre as poro-pressões de ar e de água, modificando a pressão efetiva no solo (CRUZ, 1996).

A presença de ar, ainda que sob a forma de bolhas, irá modificar o comportamento do solo no tocante à compressão e expansão, por que a um aumento de pressão da água (causado, por exemplo, pelo fluxo de água de chuva no maciço) corresponderá um processo de dissolução do ar na água e uma variação do volume ar-água. Que provocará, em seguida, uma redução da pressão da água. E o ar dissolvido poderá voltar à forma de bolha, dissolvendo-se em uma bolha de maior tamanho, com conseqüente redução do grau de saturação do solo.

Destaca-se que, a Lei de Darcy aplicada a solos não saturados, tem como uma de suas variáveis a função condutividade hidráulica, que por sua vez, é obtida por meio de modelos estatísticos que utilizam como base a distribuição dos tamanhos dos 
poros do solo, a partir da curva de retenção. Donde se conclui que a função condutividade hidráulica obtida pela metodologia acima não se aplica a solos não saturados com ar em forma de bolhas. Isso se deve ao fato de que ele apresenta comportamento, de compressão e expansão, não previsto no modelo estatístico utilizado.

\subsubsection{Equações de fluxo não saturado propostas por Fredlund e Rahardyo}

As equações de fluxo não saturado propostas por Fredlund e Rahardyo (1993) utilizam como hipótese as seguintes formulações: Equação da Continuidade, a Teoria do Adensamento, e a Relação Constitutiva de um Solo Não Saturado, associadas à Lei de Darcy, Equação 2.2, e podem ser utilizadas para descrever os fluxos de água e ar em solos não saturados levando-se em consideração a variação de volume do sistema poroso, ao contrário do que a aplicação da Lei de Darcy sem a utilização de análise acoplada.

A resolução de um determinado problema por meio de uma análise acoplada envolve diversas dificuldades como: (a) a determinação em laboratório dos coeficientes de variação de volume, da água e do ar, em função da variação da tensão normal líquida, e em função da variação da sucção; e (b) a definição do tipo de condição de carregamento a que o maciço estudado está sujeito, para que se determine o tipo de ensaio a ser executado em laboratório para a determinação dos coeficientes acima.

Fredlund e Rahardyo (1993) propõem a equação (2.17) para resolver o fluxo de água que ocorre durante um processo de consolidação.

$$
\begin{aligned}
\left(\delta \mathrm{u}_{\mathrm{w}} / \delta_{\mathrm{t}}\right)=-\mathrm{C}_{\mathrm{w}}\left(\delta \mathrm{u}_{\mathrm{a}} / \delta_{\mathrm{t}}\right)+\mathrm{c}_{\mathrm{v}} \mathrm{w}\left(\delta^{2} \mathrm{u}_{\mathrm{w}} / \delta \mathrm{y}^{2}\right) & \\
& +\left(\mathrm{c}_{\mathrm{v}} \mathrm{w} / \mathrm{k}_{\mathrm{w}}\right) \cdot\left(\delta \mathrm{k}_{\mathrm{w}} / \delta \mathrm{y}\right) \cdot\left(\delta \mathrm{u}_{\mathrm{w}} / \delta \mathrm{y}\right)+\mathrm{c}_{\mathrm{g}} \cdot\left(\delta \mathrm{k}_{\mathrm{w}} / \delta \mathrm{y}\right)
\end{aligned}
$$


Onde:

$\mathrm{C}_{\mathrm{w}}=$ constante interativa associada a equação diferencial parcial

da fase água \{i.e., $\left.\left[\left(1-\left(\mathrm{m}_{2} \mathrm{w}^{\mathrm{m}} \mathrm{m}_{1} \mathrm{w}_{\mathrm{k}}\right)\right) /\left(\mathrm{m}_{2} \mathrm{w} / \mathrm{m}_{1} \mathrm{w}_{\mathrm{k}}\right)\right]\right\}$

$\mathrm{c}_{\mathrm{v}}{ }^{\mathrm{w}}=$ coeficiente de consolidação com respeito à fase água [i.e.,

$\left.\mathrm{k}_{\mathrm{w}} /\left(\rho_{\mathrm{w}} \mathrm{g} \mathrm{m}_{2}{ }^{\mathrm{w}}\right)\right]$

$\mathrm{c}_{\mathrm{g}}=$ constante do termo de gravidade (i.e., $1 / \mathrm{m}_{2}{ }^{\mathrm{w}}$ )

$\mathrm{m}_{1} \mathrm{w}=$ coeficiente de variação de volume da água com respeito a variação da tensão normal líquida

$\mathrm{m}_{2}{ }^{\mathrm{w}}=$ coeficiente de variação de volume da água com respeito a variação da sucção

O primeiro termo do lado direito da equação (2.17) se refere à dissipação de poropressão de ar no solo, e o segundo termo do lado direito da equação à dissipação de poro-pressão de água no solo. O coeficiente de permeabilidade, $\mathrm{k}_{\mathrm{w}}$, pode variar significativamente com respeito à sucção matricial (Fig.2.2), que por sua vez pode variar na direção y. A variação da permeabilidade do solo é levada em conta nos últimos dois termos do lado direito dessa equação. Em alguns casos o último termo da equação, que se refere à componente gravitacional, pode ser negligenciado quando comparado aos demais termos. Se o termo de gravidade pode ser desconsiderado e o coeficiente de permeabilidade não variar significativamente com o espaço, o terceiro e o quarto termos da equação (2.17) podem ser negligenciados, e uma forma simplificada da equação pode ser escrita:

$$
\left(\delta \mathrm{u}_{\mathrm{w}} / \delta_{\mathrm{t}}\right)=-\mathrm{C}_{\mathrm{w}}\left(\delta \mathrm{u}_{\mathrm{a}} / \delta_{\mathrm{t}}\right)+\mathrm{c}_{\mathrm{v}}{ }^{\mathrm{w}}\left(\delta^{2} \mathrm{u}_{\mathrm{w}} / \delta \mathrm{y}^{2}\right)
$$

Fredlund e Rahardyo (1993) propõem a utilização da equação (2.18) como equação diferencial parcial para o fluxo unidimensional transiente de água em solo não saturado. Os autores apresentam equações diferenciais parciais similares às acima apresentadas, para o fluxo unidimensional transiente de ar em solo não saturado. Considerando que Rahardyo (1990) verificou que para "alguns problemas" (não fica 
claro quais) o excesso de poro-pressão de ar em maciços não saturados podem ser negligenciáveis ou rapidamente dissipados, e que nessas situações somente a equação diferencial parcial para o fluxo de água precisa ser resolvida, não serão apresentadas neste trabalho as equações referentes ao fluxo de ar.

\subsubsection{Variáveis que influenciam fluxo não saturado e a estabilidade de taludes}

Wolle (1988) concluiu que a água proveniente das chuvas que se infiltra nos solos e percola pelo maciço das encostas é o principal agente deflagrador dos movimentos de instabilização de encostas e taludes não saturados. Os principais modos de atuação dos fluxos não saturados no processo de instabilização de encostas e taludes segundo o autor são: pressões neutras de percolação; pressões hidrostáticas oriundas do preenchimento temporário de fendas e fissuras pela água; erosão superficial e interna provocada pelo escoamento da água sobre os taludes e através dos maciços; e, redução das tensões de sucção (devido à eliminação da parcela de resistência denominada coesão aparente) nos solos tropicais não saturados.

Analisando-se as variáveis, encontradas na literatura, que influenciam fluxo não saturado e que portanto influenciam a estabilidade de taludes, decidiu-se por dividilas em três categorias: fatores climáticos, externos à superfície do terreno; fatores de revestimento superficial do terreno que faz a interface entre o meio externo e o meio poroso do solo; e fatores relativos às propriedades do solo ou solos que compõem o maciço.

\subsubsection{Variáveis relativas ao clima}

As variáveis encontradas na literatura que influenciam o fluxo não saturado e a estabilidade de taludes, e são relacionadas a fatores climáticos, isto é, fatores 
externos à superfície do terreno, são três: pluviometria, temperatura e pressão barométrica. Descrevem-se a seguir as variáveis relativas ao clima.

(a) a pluviometria pode ser subdividida em: $\left(a_{1}\right)$ duração das precipitações que atingem a superfície do terreno; $\left(\mathrm{a}_{2}\right)$ sua intensidade; e $\left(\mathrm{a}_{3}\right)$ as precipitações ocorridas anteriormente ao início de um evento chuvoso, que condicionam o perfil inicial de poro-pressões de água em um dado tipo de solo.

Wolle (1988) descreve de que forma esses três fatores intervêm no fluxo de água no solo e por sua vez na estabilidade de taludes:

$\left(\mathrm{a}_{1}\right)$ "(há) movimentos de massa provocados pelo fluxo de grandes volumes de água através dos maciços, por períodos prolongados e que possam provocar subidas significativas nos níveis freáticos ou piezométricos";

$\left(\mathrm{a}_{2}\right)$ "os valores (intensidade) da precipitação que deflagra o processo (de ruptura de encostas) dependerão, e muito, de cada tipo de movimentação de massa, suas características e peculiaridades do maciço, suas descontinuidades e do acesso da água às mesmas";

$\left(\mathrm{a}_{3}\right)$ "a infiltração d'água nos solos insaturados é decisivamente regulada pela umidade pré-existente nos mesmos, ou seja, pelo seu grau de saturação. Estando os escorregamentos ora em questão associados ao mecanismo de formação e avanço das "frentes de saturação" maciço adentro, é evidente que, quanto mais saturado estiver o solo, mais facilmente se formará a frente de saturação e mais rapidamente ela avançará." Lumb (1975), Guidicini e Iwasa (1976) e Morgenstern e Matos (1975) apud Wolle (1988) confirmam a tese de que as chuvas anteriores ao evento são importante fator na deflagração de escorregamentos. Wolle (1988) calculou a precipitação total e o período de recorrência da precipitação necessária para que a frente de infiltração atinja a profundidade de $1 \mathrm{~m}$, por meio das equações propostas por Mein e Larson (1973) e por Lumb (1975) a partir de vários graus de saturação. Conclui que quanto maior o grau de saturação inicial do solo antes do evento de precipitação intensa, menor precipitação total e menor período de 
recorrência necessários para que a frente atinja a profundidade adotada, ressaltando a importância das chuvas anteriores ao evento para a deflagração de escorregamentos.

(b) a temperatura e (c) a pressão barométrica são fatores que segundo Fredlund (1993) condicionam o fluxo de ar no solo: "em condições naturais, o fluxo de ar através do solo pode ser causado por fatores como as variações de pressão barométrica, infiltração de água de chuva que comprime o ar nos poros do solo, e mudanças de temperatura". Esses fatores intervêm diretamente no potencial que provoca o fluxo de ar livre no solo que é dado pela Equação (2.19):

$$
\mathrm{h}_{\mathrm{a}}=\mathrm{u}_{\mathrm{a}} / \rho_{\mathrm{a}} \mathrm{g}
$$

Onde: $h_{a}=$ potencial que provoca o fluxo de ar livre no solo

$\mathrm{u}_{\mathrm{a}}=$ poro-pressão de $\mathrm{ar}$

$\rho_{\mathrm{a}}=$ peso específico do ar

$\mathrm{g}=$ aceleração da gravidade

\subsubsection{Variáveis relativas ao tipo de revestimento superficial}

As variáveis encontradas na literatura que influenciam fluxo não saturado e a estabilidade de taludes e são relacionadas ao tipo de revestimento superficial, isto é, que alteram o balanço hídrico do solo nu ou que promovem variação da sua resistência são: (a) a evapo-transpiração realizada por espécies vegetais; (b) a interceptação da precipitação pela vegetação; (c) o reforço da camada superficial do solo por meio do sistema radicular da vegetação; (d) a execução de revestimentos aplicados sobre a superfície do terreno que reduzem a infiltração de água no solo.

Descrevem-se a seguir as variáveis relativas ao tipo de revestimento superficial. 
(a) a evapo-transpiração realizada por espécies vegetais. De acordo com Fredlund e Rehardyo (1993) a vegetação na superfície do terreno tem a capacidade de aplicar poro-pressões de água de até 1 a 2 MPa através do processo de evapotranspiração. Segundo o mesmo autor esse efeito é função do clima, da espécie da vegetação e da profundidade das raízes.

(b) a interceptação da precipitação pela vegetação é um dos principais componentes da abstração inicial (diferença entre a precipitação e o "run-off"), segundo Alan Smith Inc. (2004). Uma vegetação de maior porte e copa intercepta parcela maior da precipitação do que uma vegetação rasteira por exemplo, resultando em menor infiltração no primeiro caso do que no segundo. Segundo esse autor o método original do U.S. Soil Conservation Service para cálculo de precipitação efetiva, ou "run-off", adotava para a abstração inicial valor de $20 \%$, porém muitos engenheiros hoje em dia consideram esse valor inaceitavelmente alto e adotam $10 \%$, assim como o software desenvolvido por Alan Smith Inc. (2004) e comercializado para o dimensionamento de sistemas de drenagem de águas pluviais. Prandini et alii (1976) e Greenway et alii (1984) apud Wolle (1989) consideram ordens de grandeza em torno de 35 a 40 \% para a abstração inicial em encostas florestadas.

(c) o reforço da camada superficial do solo por meio do sistema radicular da vegetação melhora as condições de estabilidade de uma encosta ou talude segundo Wolle (1988). Espécies vegetais perenes com raízes também perenes e resistentes à tração e ao cisalhamento, com sistema radicular difuso de modo a formar uma trama bem desenvolvida e de longo alcance, aumentam segundo esse autor a resistência ao cisalhamento do sistema solo-raízes.

(d) a execução de revestimentos superficiais como a imprimação betuminosa, a argamassa de cimento e areia (utilizada nesta pesquisa), a gunita, ou o "chunam" (revestimento em argamassa de solo-cimento ou solo-cal-cimento utilizado em Hong Kong) ou outros tipos de revestimentos aplicados sobre a superfície do terreno reduzem a infiltração de água no solo, a ponto de, praticamente evitar a formação de frentes de saturação e preservar níveis razoáveis de sucção, mesmo durante os períodos mais chuvosos, segundo Sweeney (1982) apud Wolle (1988). Zhang et al. 
(2004) consideram que de uma maneira geral engenheiros geotécnicos devem considerar a utilização de premissas de projeto que podem estar relacionadas com a permanência da sucção em taludes não saturados, baseados em análises numéricas. Medidas como a cobertura de taludes ou recompactação da camada superficial podem ser levadas em consideração para minimizar a infiltração da precipitação, e portanto manter a sucção ativa em taludes.

\subsubsection{Variáveis relativas às propriedades do solo}

As variáveis encontradas na literatura que influenciam o fluxo não saturado e a estabilidade de taludes, e são relacionadas às propriedades do solo, ou solos que compõem o talude são: (a) curva de retenção; e (b) função condutividade hidráulica. Descrevem-se a seguir as variáveis relativas às propriedades do solo.

A forma da curva de retenção de água dos solos é influenciada, segundo Calle (2000) pela distribuição granulométrica, pela distribuição granulométrica dos poros, pela estrutura do solo, e pela mineralogia das partículas do solo. Segundo esse autor solos arenosos apresentam curvas de retenção com variações mais bruscas do que solos argilosos, pois esses são mais bem graduados do que os solos arenosos, ocorrendo o mesmo com os poros desses solos. Em relação à estrutura de um solo, Calle (2000) observa que um determinado solo compactado apresenta curva de retenção com variações mais bruscas do que a do mesmo solo em condições naturais. O autor explica a diferença pelo efeito da compactação, que diminui as dimensões dos grandes poros, existentes entre os agregados, contudo não provoca alteração nas dimensões dos micro poros existentes no interior dos agregados.

Em relação à mineralogia Calle (2000) apresenta curvas de retenção obtidas por Koorevaar et al. (1983) in Fredlund e Rahardyo (1993) e Croney e Coleman (1961) in Fredlund e Rahardyo (1993), que indicam que argilas marinhas e turfas de oligotrofo jovem apresentam em geral, para um mesmo valor de sucção, um volume de água (ou uma umidade volumétrica) superior ao volume de água de uma areia de duna. 
Isso ocorre pois os argilo-mineriais (presentes nas argilas e turfas) apresentam água adsorvida em seu interior, o que não ocorre entre as partículas de quartzo e outros minerais que constituem os solos arenosos. Os solos siltosos apresentados nas curvas de retenção acima apresentam umidades volumétricas intermediárias, isto é, maiores que as das areias e menores que as umidades volumétricas das argilas.

Donde se conclui que, de uma maneira geral, as curvas de retenção dos solos argilosos são mais afastadas do eixo das ordenadas, e as curva de retenção das areias são mais próximas desse eixo. E, portanto, para uma mesma umidade volumétrica as argilas apresentam maior sucção do que as areias.

A função condutividade hidráulica é regida principalmente pela própria curva de retenção de água e pela condutividade hidráulica saturada do solo.

Segundo Richards (1974) uma camada superficial de solo saturado que perde água por exemplo por ação do gradiente gravitacional, que leva a água dessa camada para as camadas mais profundas do maciço vai progressivamente substituindo a água dos poros por ar. Nesse processo a sucção que inicialmente era igual a zero cresce.

Analisando o processo de infiltração de água no solo, das camadas superficiais em direção às camadas mais profundas do maciço, Richards (1974) analisa alguns fatores que geram a redução da condutividade hidráulica e do fluxo não saturado.

(i) o aumento sucção resulta em aumento da tensão efetiva e na redução do volume dos poros;

(ii) a redução da quantidade de água nos poros e principalmente nos macro poros que são os primeiros a perder água. Segundo a equação de Poiseuille, com a qual se calcula a vazão em tubos capilares, essa vazão é diretamente proporcional ao quadrado do raio do tubo ou poro onde ocorre o fluxo. A condutividade hidráulica e o fluxo decrescem devido à redução da quantidade de poros e do raio médio dos poros onde ocorre fluxo; 
(iii) aumento progressivo da quantidade de água que fica isolada e descontínua em diversos poros do solo, reduzindo a quantidade de áreas com água onde efetivamente ocorre fluxo de água.

Miller e Low (1963) apud Calle (2000) descrevem situações em que a entrada de ar no solo e elevações expressivas da sucção geram:

(iv) aumento da tortuosidade dos canais/poros onde ocorre fluxo, reduzindo o condutividade hidráulica e do fluxo não saturado no solo com baixa umidade;

(v) alteração na viscosidade da água, que começa a se aproximar daquela da água adsorvida pelas partículas sólidas, reduzindo o condutividade hidráulica e do fluxo não saturado no solo com baixa umidade.

Carvalho (1989) verificou a ocorrência de comportamento "fundamentalmente heterogêneo" entre os resultados de ensaios de condutividade hidráulica saturada obtidos para a areia argilosa retirada de área experimental implantada na Serra do Mar em Cubatão/SP. Os resultados variaram entre $3 \times 10^{-3}$ e $1 \times 10^{-4} \mathrm{~cm} / \mathrm{s}$, resultando em um valor médio para a condutividade hidráulica saturada de $7 \times 10^{-4} \mathrm{~cm} / \mathrm{s}$. $\mathrm{O}$ autor explicou a variabilidade dos resultados obtidos, ou sua "discrepância" pela influência de macroestrutura como fendas, trincas, núcleos argilosos, etc. A variabilidade detectada em relação ao coeficiente de permeabilidade não foi confirmada em relação a outras características geotécnicas do solo estudado pelo autor, como peso específico aparente seco, onde poderia ser detectada alguma coerência de dados com permeabilidade.

Carvalho (1989) verificou divergência entre os resultados de ensaios infiltração realizados em campo, que indicaram velocidades de fluxo, e de alteração das poropressões de água, maiores que as obtidas em simulações realizadas pelo modelo de Mein e Larsson (1973), por meio da existência das macroestruturas citas acima. A explicação fornecida por Carvalho (1989) foi justificada principalmente ao apresentar resultado de ensaio de condutividade hidráulica saturada realizado em corpo de prova de menor diâmetro que os anteriormente ensaiados, cujo resultado foi menor 
que aqueles, $5 \times 10^{-6} \mathrm{~cm} / \mathrm{s}$. Segundo o autor quanto maior a amostra maior a probabilidade de se ensaiar macroestruturas, resultando em maiores coeficientes de permeabilidades.

Santos (2004), assim como Carvalho (1989), prevê "a presença de facetas peculiares que fazem com que o comportamento real do solo se distancie do comportamento do solo idealizado. Como exemplos desses tipos de singularidades o autor citou a "infiltração em fingers, em macro poros e fendas e o fluxo afunilado no contato entre solos siltosos e solos arenosos sotopostos".

Por outro lado, o trabalho publicado por Rezaur (2003) apresentou resultados de monitoramento de talude não saturado que o autor descreveu como "variação rápida das poro-pressões de água" e diz não saber justificar o comportamento. Dados obtidos na pesquisa aqui apresentada indicam resultados semelhantes aos obtidos por Carvalho (1989) e Rezaur (2003). Nos três trabalhos mencionados, os solos apresentavam baixas sucções e elevados graus de saturação, maiores que 85 \%, situação em que a equação 2.14 não é válida.

Algum fenômeno diverso do levado em consideração pelos autores não estaria ocorrendo? A alteração da sucção não ocorreria por meio de outro fenômeno além do fluxo de água? A transmissão de pressão no solo não poderia ocorrer por meio dos poros preenchidos com água, sem que ocorresse infiltração? Resultados apresentados no Capítulo 4 deste trabalho, item 4.4, indicam a ocorrência de situação similar às verificadas pelos autores citados acima.

Santos (2004) realizou análise paramétrica da infiltração de água de chuva em talude da região de São Carlos, estudado por Calle (2000), e sua influência na estabilidade de talude não saturado. O modelo de resistência adotado foi o proposto por Fredlund et al. (1978). As análises de fluxo foram realizadas utilizando o programa SEEP/W com três tipos de solo areia (A), silte argiloso (B) e areia argilosiltosa (C) teóricos, considerando que tivessem mesma curva de retenção e parâmetros de resistência. As análises de estabilidade de talude foram realizadas com o programa SLOPE/W. 
O autor verificou que a função condutividade hidráulica e a pressão de entrada de ar são as características ou propriedades dos solos que mais influenciam no comportamento da infiltração de água no solo e conseqüentemente da estabilidade de taludes. Quanto maior a condutividade hidráulica inicial, isto é, para a sucção inicial de campo antes do início da precipitação; e maiores a condutividade hidráulica saturada do solo e a pressão de entrada de ar, mais rápido é o avanço da frente de umedecimento e conseqüentemente maiores as taxas de redução do fator de segurança do talude.

\subsubsection{Modelos de previsão da infiltração em solos não saturados}

Apresentam-se a seguir dois modelos analíticos que permitem determinar a infiltração total de uma dada precipitação no solo.

\subsubsection{Modelo de Green Ampt}

A equação de desenvolvida por Green e Ampt se baseia na infiltração de água em solo relativamente seco com uma frente de saturação íngreme. A Figura 2.7 ilustra as várias umidades do solo em função da profundidade, $z$, do terreno, em um determinado instante, quando a frente de umedecimento avançou um comprimento L. 


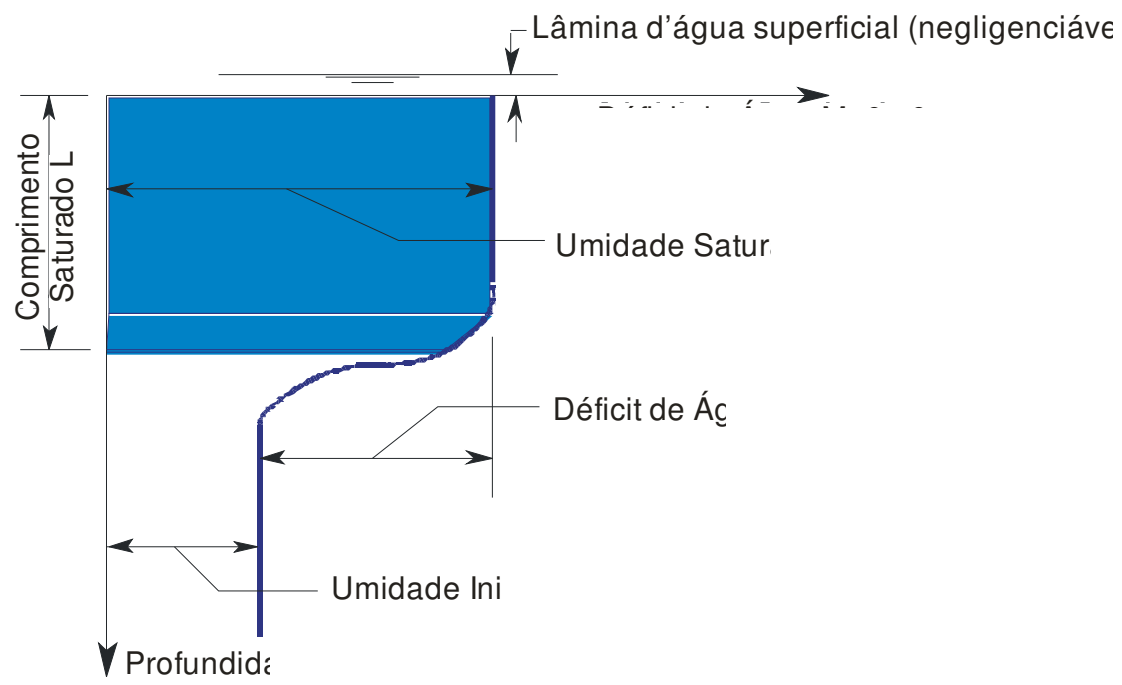

Figura 2.7: Frente de umedecimento conforme prevê o modelo de Green Ampt

A passagem dessa frente causa aumento da umidade do solo a partir de um determinado valor inicial até o valor de saturação. Essa diferença é definida como déficit de água $M$, isto é:

$$
M=\Theta s-\Theta i
$$

Tipicamente para solos secos $M$ tem valor na faixa de $0.2<M<0.5$ dependendo do índice de vazios do solo, com valores menores para solos pré-umedecidos.

Se a condutividade hidráulica de um solo é $K$, em $\mathrm{mm} / \mathrm{h}$, então pela lei de Darcy:

$$
\mathrm{v}_{\mathrm{s}}=\mathrm{dL} / \mathrm{dt}=-\mathrm{k}_{\mathrm{s}} \cdot\left(\delta \mathrm{h}_{\mathrm{w}} / \delta \mathrm{y}\right)
$$

Onde $\left(\delta \mathrm{h}_{\mathrm{w}} / \delta \mathrm{y}\right)$ representa o gradiente hidráulico.

A carga que causa infiltração é dada pela equação:

$$
\mathrm{h}=\mathrm{h}_{0}+\mathrm{L}+\mathrm{S}
$$




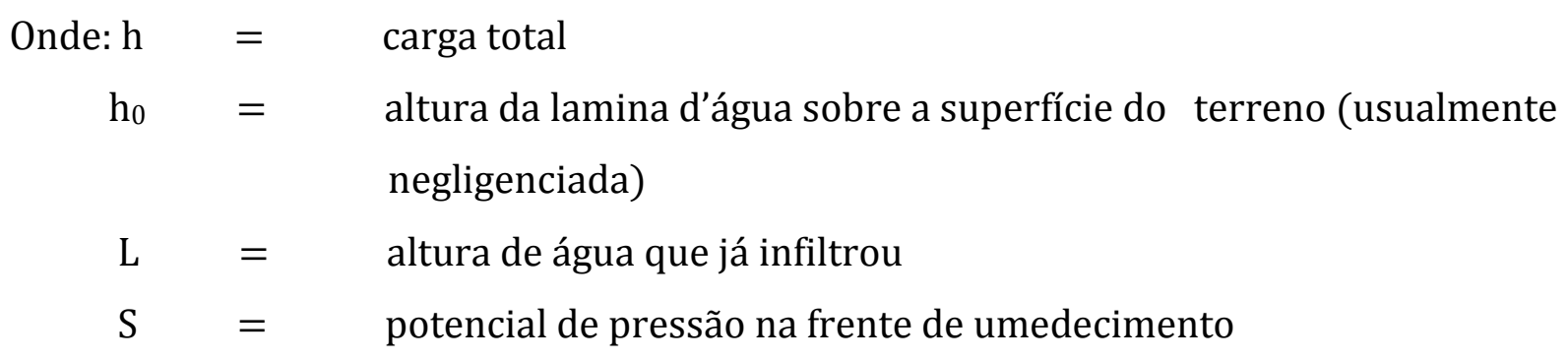

O potencial de pressão, ou sucção em termos de altura piezométrica, em milímetros, é devido à atração capilar nos vazios do solo. Ela é maior para solos finos como argilas e pequena para solos granulares como a areia.

O volume total infiltrado entre a superfície do terreno e a frente de umedecimento é definido pela equação:

$$
\mathrm{F}=\mathrm{L} \times \mathrm{M}
$$

A taxa de infiltração $f=d F / d t$ é dada pela equação:

$$
\mathrm{F}=\mathrm{K}[1+(\mathrm{M} \times \mathrm{S} / \mathrm{F})]
$$

Visando calcular a precipitação efetiva, que flui superficialmente, essa equação deve ser resolvida para cada intervalo de tempo durante a precipitação. Conforme mostra a Figura 2.8, três casos devem ser considerados, nos quais a taxa de infiltração, para cada tempo $t$ e $t+\delta t$, são denotados por $f_{1}$ e $f_{2}$, respectivamente, e a intensidade da chuva $i$ é adotada como sendo constante durante o intervalo de tempo. Cada caso é considerado separadamente. 


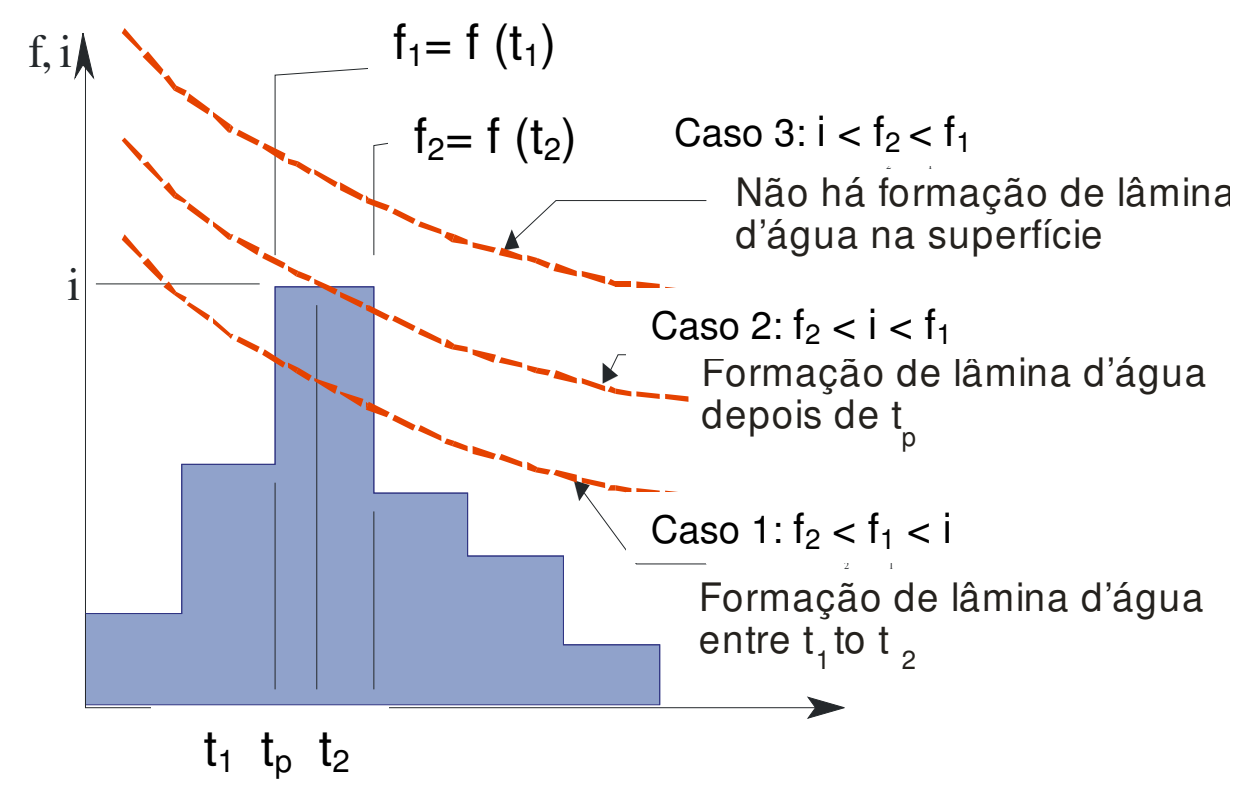

Figura 2.8: Três casos considerados no modelo de Green Ampt

Caso (1)

$$
f_{2}<f_{1}<i
$$

a intensidade de da precipitação excede a capacidade de infiltração do solo ao longo de todo o intervalo de tempo considerado portanto, o escoamento superficial deve ocorrer durante todo o intervalo de tempo $\delta t$.

Caso (2)

$$
f_{2}<i<f_{1}
$$

No início do intervalo de tempo $\delta t$ a capacidade de infiltração $f_{1}$ excede a intensidade da precipitação mas isso muda antes do intervalo de tempo terminar. $O$ runoff inicia durante o tempo $\delta t$.

Caso (3)

$$
i<f_{2}<f_{1}
$$

A chuva infiltra durante todo o intervalo de tempo e escoamento superficial não ocorre.

O algoritmo de solução usado pode ser sumarizado conforme segue:

Se ij>fj então o caso (1) se aplica e 
$F_{j+1}=F_{j}+K \Delta t+M \operatorname{Sin}\left[\frac{\left(F_{j+1}+M S\right)}{\left(F_{j}+M S\right)}\right]$

A precipitação efetiva é dada pela equação:

$$
i_{e f t}=i-\frac{\left(F_{j+1}-F_{j}\right)}{\Delta t}
$$

Se $i j<=f j$ então um dos casos (2) ou (3) se aplica. Se assume que o caso (3) se aplica - isto é, toda a chuva infiltra durante o intervalo de tempo $\delta t$ - então se pode estimar:

$$
F_{J+1}=F_{j}+i \Delta t
$$

e

$$
t_{j+1}=K\left(1+\frac{M S}{F_{j+1}}\right)
$$

Verifica-se se $i_{j}<=f_{j+1}$. Se verdadeiro, então o caso (3) se aplica e:

$$
i_{\text {eff }}=0
$$

Se $i_{j}>f_{j+1}$ então o caso (2) se aplica. $O$ volume requerido para causar runoff é calculado por:

$$
F_{p}=\frac{K M S}{\left(i_{j}-K\right)}
$$

O tempo para o início do runoff $\delta t$ pode ser obtido pela equação: 


$$
\delta t=\frac{\left(F_{p}-F_{j}\right)}{i}
$$

Então:

$$
F_{j+1}=F_{j}+K(\Delta t-\delta t)+\operatorname{MSn}\left[\frac{\left(F_{j+1}+M S\right)}{\left(F_{j}+M S\right)}\right]
$$

E a precipitação efetiva pode ser estimada por:

$$
i_{e f t}=i-\frac{\left(F_{j+1}-F_{i}\right)}{\Delta t}
$$

A aplicação desse algoritmo para cada período de tempo da precipitação resulta na precipitação efetiva para superfícies impermeáveis e permeáveis. Se há abstração, isto é, parcela da precipitação que é retida na vegetação, ela deve ser subtraída dos valores de entrada do algoritmo. Dessa maneira a precipitação efetiva calculada produz diretamente o runoff da precipitação.

No método de Green Ampt devem ser fornecidos os seguintes parâmetros de entrada:

(a) O déficit de água $M$ que é adimensional;

(b) sucção fornecida em mm;

(c) condutividade hidráulica do solo em $\mathrm{mm} / \mathrm{h}$; e

(d) abstração em mm.

Rawls et al (1983) apud Alan A. Smith (2004) sugerem alguns valores típicos para as variáveis a serem utilizadas no cálculo de infiltração em solo, utilizando-se o modelo de Green Ampt, que são mostrados na Tabela 2.2. 
Tabela 2.1: Valores típicos para as variáveis de entrada do Modelo de Green Ampt (RAWLS, 1983), apud Alan A. Smith (2004)

\begin{tabular}{|l|l|l|l|c|}
\hline Tipo de solo & Porosidade & $\begin{array}{c}\text { Porosidade } \\
\text { efetiva }(\mathbf{M})\end{array}$ & $\begin{array}{c}\text { Sucção } \\
(\mathbf{m m})\end{array}$ & $\begin{array}{c}\text { Condutividade } \\
\text { Hidráulica } \\
(\mathbf{m m} / \mathbf{h})\end{array}$ \\
\hline Areia & 0.437 & 0.417 & 49.5 & 117.8 \\
\hline Areia siltosa & 0.437 & 0.401 & 61.3 & 29.9 \\
\hline Silte arenoso & 0.453 & 0.412 & 110.1 & 10.9 \\
\hline Silte & 0.463 & 0.434 & 88.9 & 3.4 \\
\hline Silte-arg- aren & 0.398 & 0.330 & 218.5 & 1.5 \\
\hline Silte argiloso & 0.464 & 0.309 & 208.8 & 1.0 \\
\hline Argila arenosa & 0.430 & 0.321 & 239.0 & 0.6 \\
\hline Argila siltosa & 0.479 & 0.423 & 292.2 & 0.5 \\
\hline Argila & 0.475 & 0.385 & 316.3 & 0.3 \\
\hline
\end{tabular}

\subsubsection{Modelo de Carvalho}

O modelo proposto por Carvalho (1989) representa de maneira simplificada a infiltração de água no solo por meio da elevação da umidade do solo durante a infiltração, de tal sorte que a umidade na frente de umedecimento não atinge a umidade de saturação entre o tempo de início da infiltração $t_{0}$ um dado tempo $t_{1}$ maior que $t_{0}$, conforme mostra a Figura 2.9. O modelo prevê que a expulsão do ar ocorre com facilidade durante a infiltração, isto é, que o ar intersticial é livre.

O modelo admite as seguintes hipóteses simplificadoras:

- solo homogêneo;

- fluxo vertical;

- condutividade hidráulica como função da umidade;

- possibilidade do estabelecimento de um intervalo de umidade no qual o potencial de pressão seja função da umidade (no caso da infiltração, as funções de interesse são aquelas relativas ao umedecimento); e,

- perfil de umidade inicial do maciço constante. 


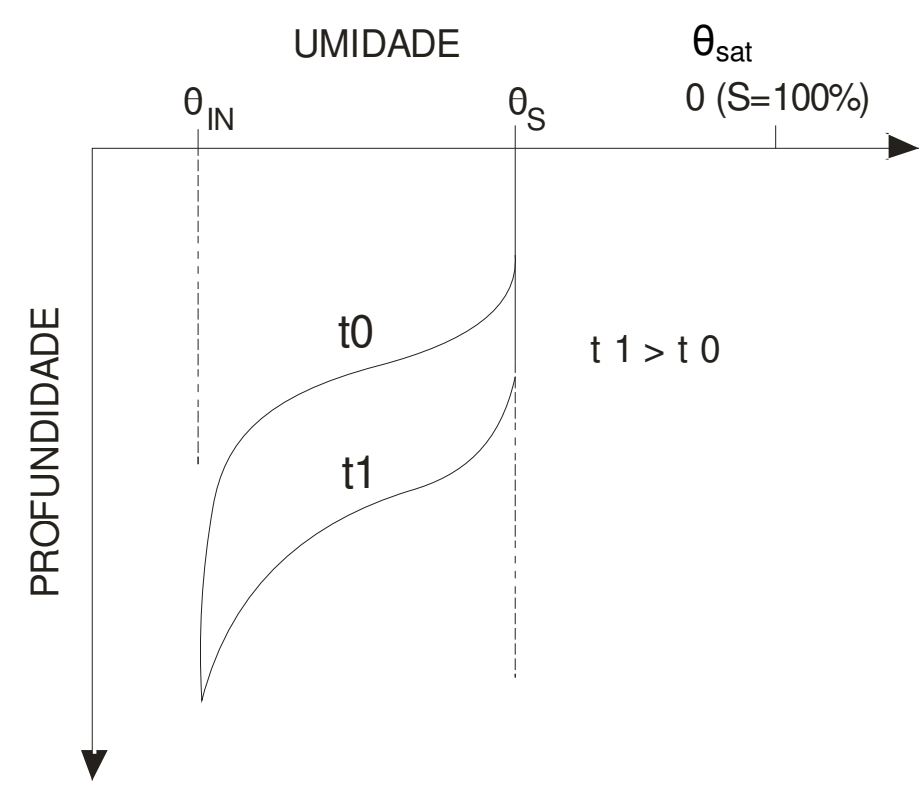

Figura 2.9: Perfil simplificado de infiltração segundo o Modelo de Carvalho (1989)

Carvalho (1989) analisa os trabalhos de Mein Larson (1973) e Matos (1974) que descrevem a infiltração como um processo no qual ocorre a saturação do perfil de solo a partir da superfície do terreno, associando-a ao avanço de uma frente de saturação, e o de Bodman e Colman (1984), que estudando empiricamente a infiltração vertical em colunas de solo granular, a partir da inundação de sua extremidade superior, identificam quatro zonas distintas:

- zona de saturação: uma camada delgada superficial onde ocorre a saturação completa é atingida (S = $100 \%$ );

- zona de transição: zona onde ocorre uma diminuição da umidade com a profundidade, (S = 80 a $100 \%)$

- zona de transmissão: região onde a umidade é essencialmente constante com a profundidade, que segundo Lambe (1951) apresenta valores máximos de saturação em torno de $80 \%$;

- zona de umedecimento: zona onde ocorre novamente uma diminuição da umidade com a profundidade ( $\mathrm{S}=80 \%$ a umidade inicial); 
A existência da zona de transição é explicada por Philip (1957) e Youngs (1957) por meio do aprisionamento de bolhas de ar no interior do solo, devido ao rápido preenchimento de alguns poros menores, anteriormente aos maiores, efeito esse que deixaria de existir apenas numa delgada camada superficial, dada a facilidade que existiria, nessa região, para que o fluxo de ar ocorra na direção da atmosfera.

A equação da velocidade de infiltração entre dois pontos localizados na zona de umedecimento do maciço em que ocorre infiltração, proposta por Carvalho (1989), é:

$$
\mathrm{v}=-\mathrm{k}\left(\theta_{\mathrm{s}}\right) \cdot\left\{\left(\mathrm{h}_{\mathrm{p} 0}-\mathrm{h}_{\mathrm{p} 1}\right) /\left(\mathrm{z}_{1}-\mathrm{z}_{0}\right)+\left[\left(\mathrm{z}_{1}-\mathrm{z}_{0}\right) /\left(\mathrm{z}_{1}-\mathrm{z}_{0}\right)\right]\right\}
$$

Onde: $\quad \mathrm{v} \quad=$ velocidade de fluxo

$\mathrm{k}\left(\theta_{\mathrm{s}}\right) \quad=$ condutividade hidráulica, função da umidade volumétrica $\theta_{\mathrm{s}}$

$\theta_{\mathrm{s}} \quad=$ umidade volumétrica na zona de transmissão, (ver Figura 2.6) obtida por meio de medições de campo da sucção lançada na curva de retenção

$\left(\mathrm{h}_{\mathrm{p} 0}-\mathrm{h}_{\mathrm{p} 1}\right)=$ diferença de potencial de pressão entre os pontos 0 e 1

$\left(\mathrm{z}_{1}-\mathrm{z}_{0}\right) \quad=$ diferença entre as cotas dos pontos $1 \mathrm{e} 0$

Se a alimentação superficial for decorrente de chuva, é necessário comparar a capacidade de infiltração $\mathrm{Cl}$, que é igual à velocidade de fluxo (v), com a intensidade pluviométrica (I). $\mathrm{Cl}$ é definida como a máxima velocidade com que a água é capaz de penetrar no solo, dada pela Equação 2.35:

$$
\mathrm{CI}=\mathrm{v}=\mathrm{k}\left(\Theta_{\mathrm{s}}\right) \cdot\left\{\left(\mathrm{h}_{\mathrm{p} 1}-\mathrm{h}_{\mathrm{p} 0}\right) /\left(\mathrm{z}_{1}-\mathrm{z}_{0}\right)+\left[\left(\mathrm{z}_{1}-\mathrm{z}_{0}\right) /\left(\mathrm{z}_{1}-\mathrm{z}_{0}\right)\right]\right\}
$$

Como $\left(z_{1}-z_{0}\right)$ varia com o tempo, $\left(h_{p 1}-h_{p 0}\right) /\left(z_{1}-z_{0}\right)$ é decrescente com o tempo, se houver alimentação constante, conforme indicado na Figura 2.10. 


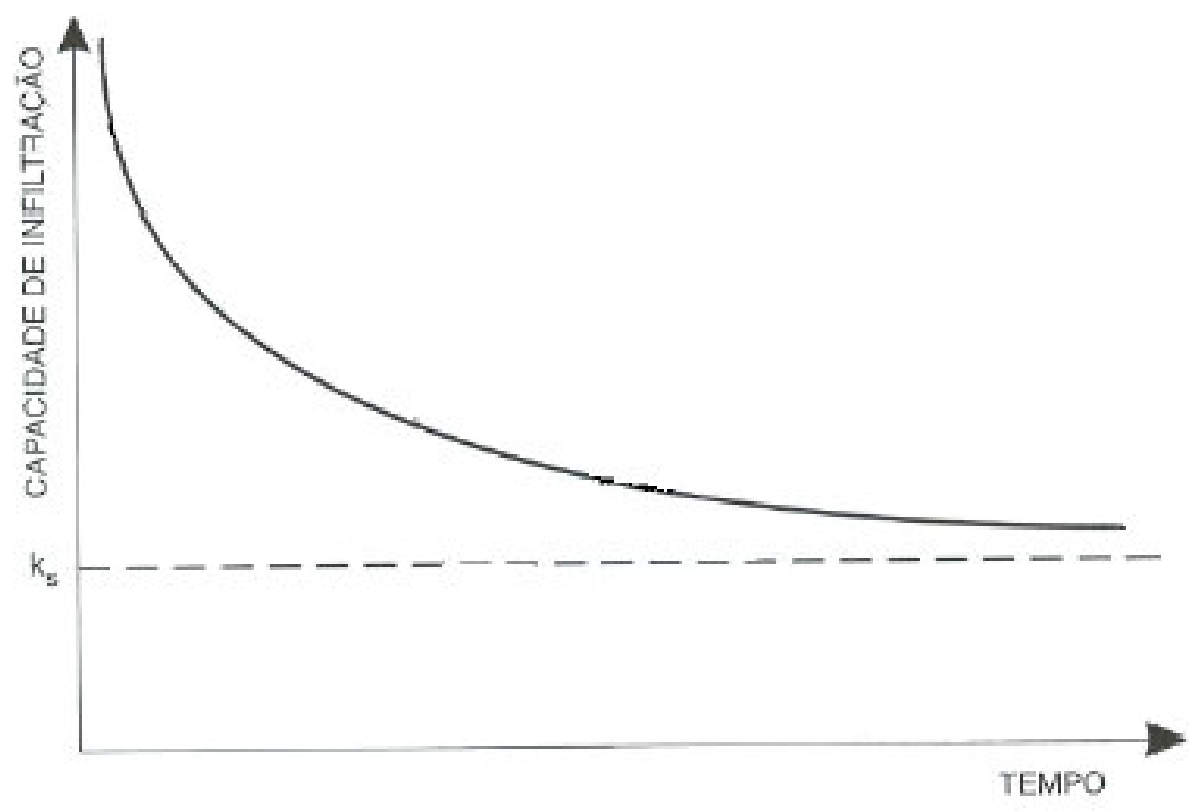

Figura 2.10: Variação da capacidade de infiltração Cl com o tempo, Carvalho (1989)

\subsection{Mecanismos de instabilização de taludes}

Apresentam-se a seguir os principais mecanismos de instabilização de taludes em solo, segundo Wolle (1988):

- Mecanismo clássico, que envolve a elevação do nível d'água pré-existente devido ao fluxo de água infiltrada. Neste mecanismo admite-se a formação de uma rede de fluxo paralela ou subparalela ao talude, sustentada numa camada ou horizonte impermeável ou significativamente menos permeável que os horizontes superficiais. Caso isso ocorra, a subida da superfície freática, ou seja, a expansão da rede devido ao afluxo da água de chuva provoca o aumento das pressões neutras de percolação até que se atinja uma condição crítica que deflagre a ruptura. 
- Mecanismo produzido por uma frente de saturação que atinja um nível d'água pré-existente, ocorrendo então um rápido aumento das pressões neutras e elevação rápida do nível d'água no maciço deflagrando escorregamento.

- Mecanismo associado ao efeito da saturação pela infiltração das águas de chuva em solos não saturados, provocando a eliminação ou mesmo a redução da sucção, chegando até a anular o intercepto de coesão do solo, o que é suficiente para provocar a ruptura de taludes.

- Mecanismo proposto por Vaughan (1985) e ainda não confirmado segundo Wolle (1988), associa a infiltração de água de chuva em taludes sem nível d'água pré-existente ou profundo, com a formação de frente de saturação que pode provocar o aparecimento de pressões neutras positivas, em casos de solos com permeabilidade decrescente com a profundidade, o que deflagraria a ruptura de taludes.

- Mecanismo de instabilização causado por corte ou erosão principalmente na base de taludes, provocando seu desconfinamento e o aparecimento de trincas de tração em sua superfície e gerando alteração no estado de tensões existente antes da alteração de sua geometria e redução do coeficiente de segurança do talude. O posterior preenchimento destas trincas com água das chuvas provocando pressões hidrostáticas ao longo de suas paredes costuma ser o agente deflagrador do processo, entre outros mecanismos como os anteriormente citados.

Analisando-se os mecanismos de instabilização de taludes em solo, apresentados acima, verifica-se que o estudo e a compreensão das variáveis que condicionam o fluxo não saturado e a forma como ocorrem as variações de poro-pressão de água no solo, são de grande importância para a ampliação do entendimento dos mecanismos de ruptura de taludes.

Estudos como o de Campo (1984) têm sido realizados visando identificar se rupturas em taludes não saturados ocorreram com poro-pressões positivas (pressão neutra 
positiva) ou negativas (sucção). Campos (1984) observou que ambas as situações foram identificadas.

Em seu estudo Campos (1984) analisou por meio de retro-análises o efeito da água como responsável pela instabilização de sete taludes em solo residual no sudeste brasileiro, a saber, Catingueiro (1973), Estrada do Jequiá, Emboque do Túnel TA-6, Julião, Virataboa (1973), Mont Serrat (1928 e 1956) e Caneleira. Concluiu que alguns taludes romperam pela redução parcial da sucção para patamares entorno de $40 \mathrm{kPa}$. Outros taludes romperam com pressões neutras levemente positivas, cerca de $+5 \mathrm{kPa}$, e outros instabilizam-se com pressões neutras positivas, $+50 \mathrm{kPa}$. Em todos os casos a perda total ou parcial da sucção foi causada pela infiltração da água de chuva.

Considerando que engenheiros geotécnicos buscam projetar e calcular a estabilidade de taludes de maneira a evitar a ocorrência de escorregamentos, as maiores dificuldades parecem estar associadas: (a) ao efeito da variação de poropressão de água na estabilidade de taludes sujeitos a fluxos não saturados e saturados; e (b) ao entendimento das variações da resistência ao cisalhamento e de volume do solo. De fato, segundo Fredlund e Rahardyo (1993) freqüentemente há uma interação simultânea entre os três aspectos da mecânica dos solos não saturados. O fluxo não saturado produz variação na resistência do solo e em seu volume.

Nos cálculos de estabilidade de taludes não saturados freqüentemente adotam-se parâmetros de resistência do solo subavaliados ou saturados para compensar a redução ou eliminação da coesão aparente provocada por fluxo de água durante períodos chuvosos. Nesse sentido, estudos têm sido desenvolvidos para ampliar o conhecimento dos fatores que condicionam o fluxo não saturado.

Wolle (1988) analisou escorregamentos translacionais na Serra do Mar considerando aspectos geológicos, geotécnicos e hidrológicos dessa área. Realizou leituras de sucção em áreas piloto da serra, ensaios para determinação do coeficiente de permeabilidade e resistência ao cisalhamento dos solos coluvionares 
e saprolíticos existentes, e calculou fatores de segurança dos taludes considerando diferentes umidades dos solos.

Os parâmetros de resistência médios obtidos em ensaios de cisalhamento direto e triaxiais com sucção controlada indicaram $\mathrm{c}=6 \mathrm{kPa}$ e $\Phi=34^{\circ}$ para solo coluvionar na umidade natural, $c^{\prime}=1 \mathrm{kPa}$ e $\Phi^{\prime}=34^{\circ}$ para solo coluvionar na inundado, $\mathrm{c}=12$ $\mathrm{kPa}$ e $\Phi=45^{\circ}$ para solo saprolítico na umidade natural e $\mathrm{c}^{\prime}=4 \mathrm{kPa}$ e $\Phi^{\prime}=39^{\circ}$ para solo saprolítico inundado. Os cálculos de estabilidade de talude realizados com parâmetros de solo na condição de umidade natural indicaram fatores de segurança entre 1,6 e 2,1, e os cálculos realizados com parâmetros de solo inundado indicaram fatores de segurança entre 0,9 e 1,2.

Considerando os fatores de segurança obtidos, Wolle (1988) explicou a ocorrência de escorregamentos translacionais na Serra do Mar pela eliminação da sucção em porções suficientemente profundas e extensas dos solos da encosta provocada pela infiltração das águas de chuva. Concluiu que a eliminação das tensões de sucção e a redução da resistência do solo por si só deflagraram a instabilização.

Wolle (1988) concluiu também que nas condições estudadas é desnecessário o aparecimento de pressões neutras positivas para que ocorram escorregamentos. Comprovou também a correlação entre instabilizações das encostas da Serra do Mar e a pluviometria por meio "de uma análise histórica dos principais eventos registrados nas últimas duas décadas (1970 e 1980), existir uma nítida de dependência entre deflagração de escorregamentos e as condições pluviométricas." O autor propugna a utilização sistemática de revestimentos de taludes de cortes e aterros como sistemas de proteção que provoquem reduções significativas na infiltração de água e que, desta forma, impeçam o avanço das frentes de saturação maciço adentro.

Calle (2000) analisou ruptura de talude em solo residual não saturado da região de São Carlos. Realizou leituras de sucção no talude rompido, ensaios para determinação do coeficiente de permeabilidade e resistência ao cisalhamento do 
solo arenoso existente no local, e calculou fatores de segurança do talude considerando diferentes umidades dos solos.

Verificou que a sucção varia ao longo do ano entre 1 e $59 \mathrm{kPa}$, com sucções decrescentes com a profundidade de até 3,3 $\mathrm{m}$, sem a ocorrência de pressões neutras positivas. Os ensaios de permeabilidade em campo indicaram valores próximos dos obtidos em laboratório $4 \times 10^{-2} \mathrm{~m} / \mathrm{s}$.

Os parâmetros de resistência médios obtidos em ensaios triaxiais drenados tipo CD em solo saturado por contrapressão indicaram c' $=0 \mathrm{kPa}$ e $\Phi^{\prime}=35^{\circ}$ e em ensaios triaxiais não drenados tipo UU para solo não saturado na umidade natural $21 \%$, correspondendo a sucção de $20 \mathrm{kPa}, \mathrm{c}=11 \mathrm{kPa}$ e $\Phi=22^{\circ}$. Os cálculos de estabilidade realizados com parâmetros de solo na condição saturada indicaram fator de segurança igual a 0,6 , e os cálculos com solo na condição não saturada indicaram fator de segurança igual a 1,1.

Considerando os fatores de segurança obtidos, Calle (2000) concluiu que o talude escorregou em estado não saturado, e que a redução da sucção matricial, causada pela infiltração da água de chuva, provocou redução da resistência ao cisalhamento e a ruptura do talude estudado. 


\section{CAMPO EXPERIMENTAL}

\subsection{Introdução}

O Campo Experimental localiza-se em área de risco geológico-geotécnico pertencente à Prefeitura Municipal de São Paulo. A área se situa em favela do Núcleo F da Gleba São Francisco, distrito de São Mateus, zona leste da Capital Paulista. A área foi cedida pela prefeitura municipal para a execução da pesquisa. $\mathrm{Na}$ Figura 3.1 pode-se ver: ao centro, um grupo de moradias de favela; acima, o talude experimental e a cicatriz de escorregamento ocorrido em 1998, que destruiu uma moradia da favela; e abaixo se pode ver parte de linha de drenagem onde passa um córrego.

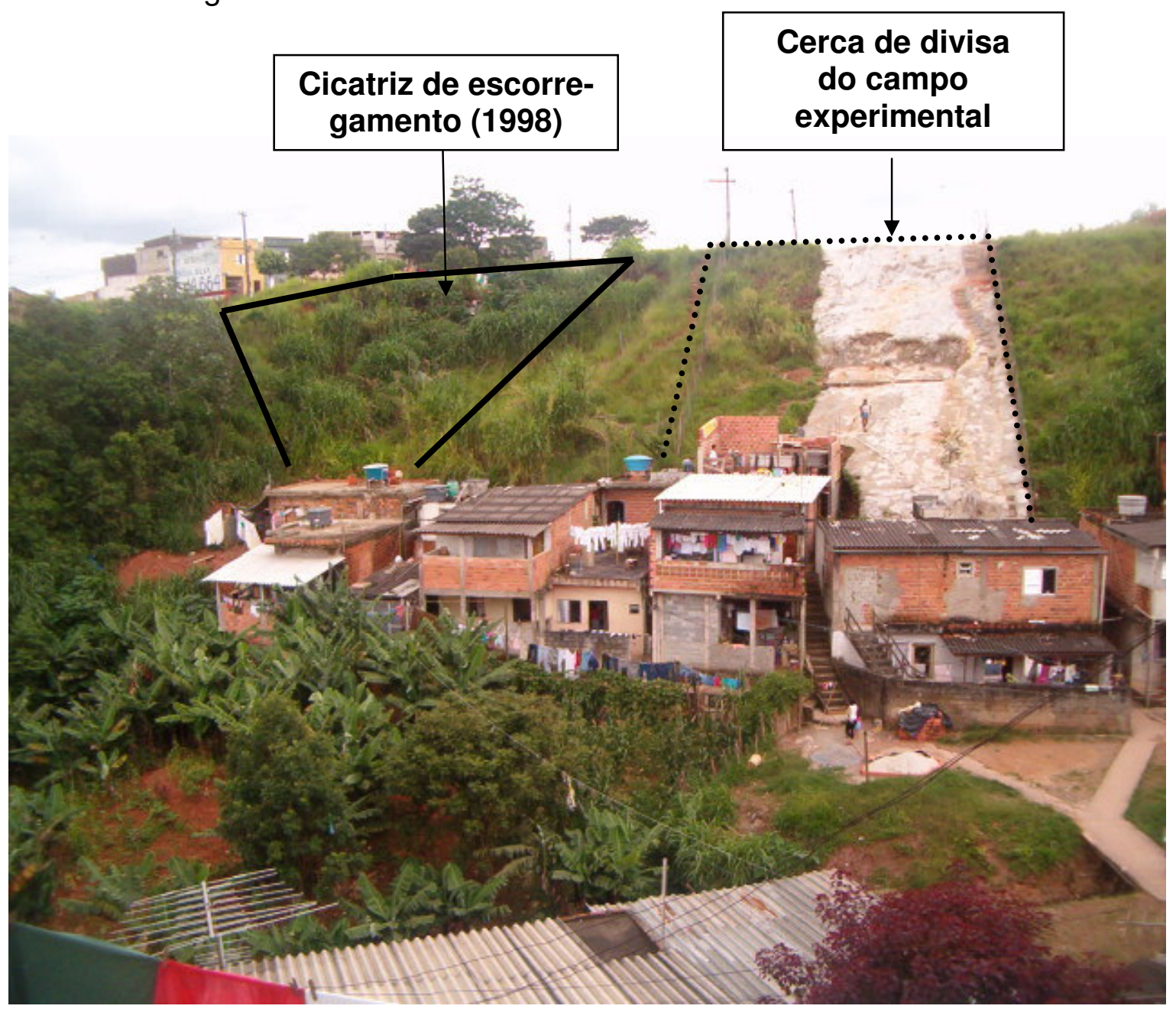

Figura 3.1: Campo experimental 
Um segundo escorregamento foi registrado em 2004 no talude citado acima. 0 escorregamento invadiu a Travessa Paulo Tavares da Silva, conforme pode ser visto na Figura 3.2. Nessa figura pode-se ver parte do material rompido, sendo que a outra parte foi removida pelos moradores da favela. Em destaque, com linha preta, pode ser vista a cicatriz do escorregamento e em primeiro plano a continuação do talude, contido por muro construído com corpos de prova de concreto, construído pelos moradores da favela.

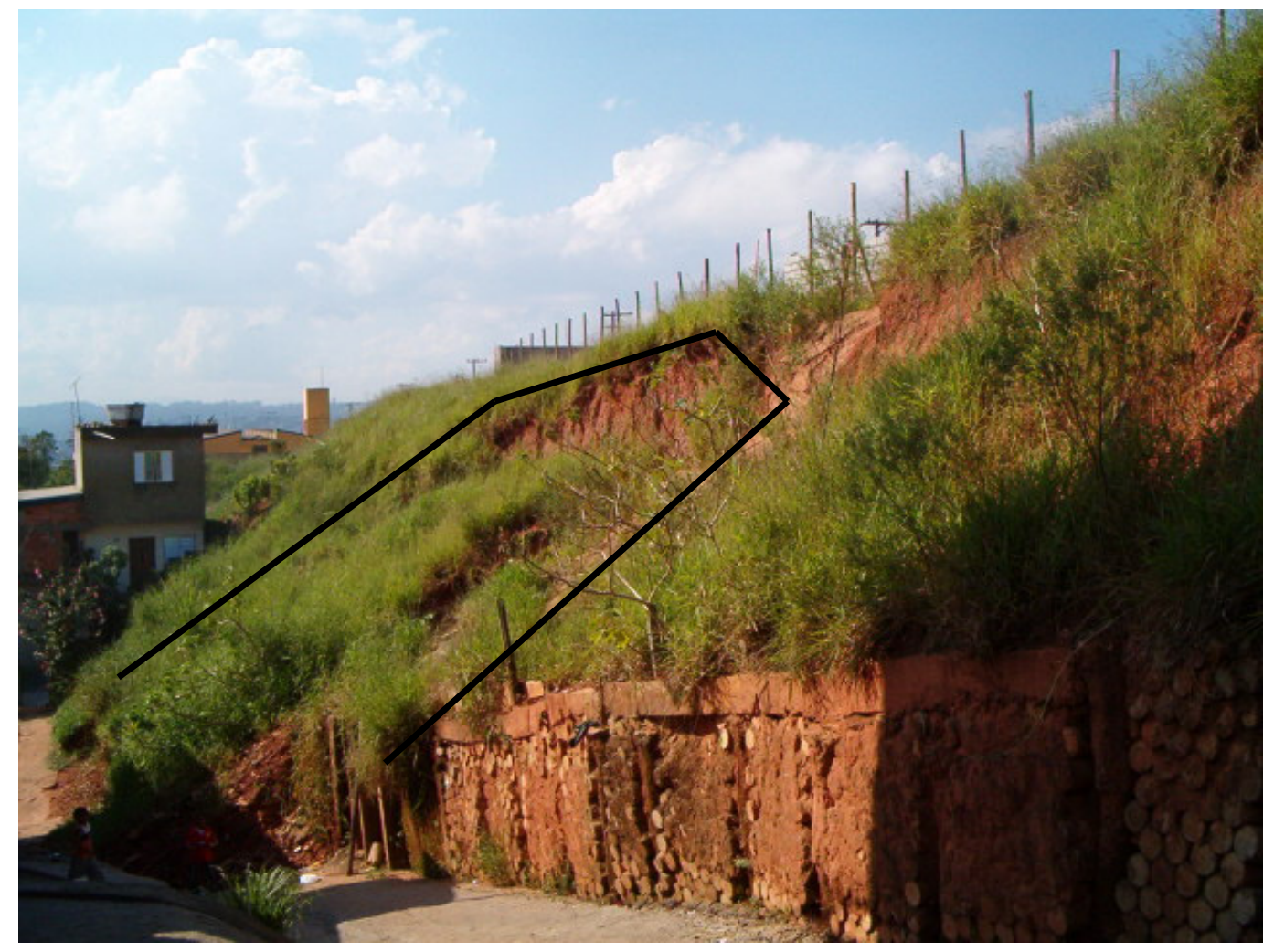

Figura 3.2: Cicatriz de escorregamento (2004)

O talude existente na área de risco geológico-geotécnico, indicada na Figura 3.3, tem cerca de $150 \mathrm{~m}$ de comprimento, altura variável de $5 \mathrm{~m}$ a $17 \mathrm{~m}$ e inclinação variando de $28^{\circ}$ a sub-vertical. Nessa figura também podem ser vistos o campo experimental, inclusive sua cerca de divisa, a locação das sondagens a trado (ST) realizadas, e a localização das rupturas apresentadas acima. 


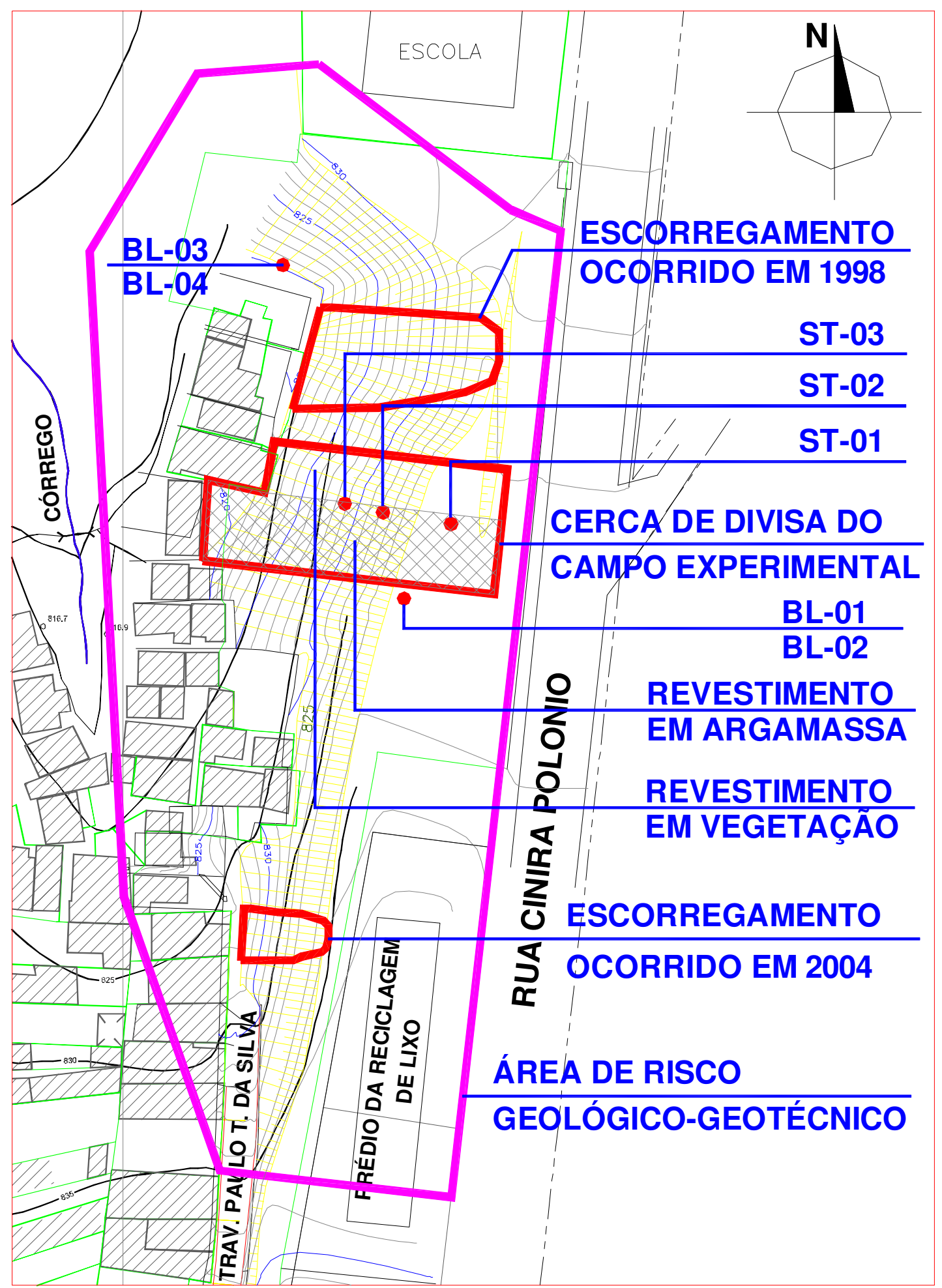

Figura 3.3: Planta da área de risco geológico-geotécnico e da implantação do campo experimental 
O campo experimental foi cercado com arame farpado para proteção dos instrumentos. Tem $16 \mathrm{~m}$ de largura e $40 \mathrm{~m}$ de comprimento. $O$ talude, no trecho do campo experimental, tem cerca de $15 \mathrm{~m}$ de altura e inclinação de $28^{\circ}$.

Na porção sul do campo experimental foi cortada a vegetação existente e aplicada camada de argamassa de cimento e areia com espessura média de $3 \mathrm{~cm}$ sobre a superfície do solo, e na porção norte o revestimento vegetal de capim existente foi mantido. A porção do campo experimental com vegetação tem cerca de $6 \mathrm{~m}$ de largura e a porção argamassada tem $10 \mathrm{~m}$ de largura. Os detalhes geométricos do talude estão apresentados na Tabela 3.1.

Tabela 3.1: Caracterização do campo experimental

\begin{tabular}{|l|c|c|}
\hline \multicolumn{1}{|c|}{ Variável } & Porção com Vegetação & Porção Argamassada \\
\hline Comprimento $(\mathrm{m})$ & 35 & 40 \\
\hline Largura Talude $(\mathrm{m})$ & 6 & 10 \\
\hline Área $\left(\mathrm{m}^{2}\right)$ & 210 & 400 \\
\hline Ângulo do Talude $\left(^{\circ}\right)$ & 28 & 28 \\
\hline Altura do Talude $(\mathrm{m})$ & 14,2 & 15,0 \\
\hline Aspecto * & Oeste & Oeste \\
\hline Forma do Talude & Semi-plano & Semi-plano \\
\hline${ }^{*}$ Direção ortogonal à face do talude \\
\hline
\end{tabular}

\subsection{Caracterizações geológico-geotécnica e geomorfológica}

Perfil geológico-geotécnico do terreno foi definido a partir de amostras deformadas de solo de furos de sondagem a trado realizados no talude. Três sondagens (ST-01 a ST-03) foram realizadas até a profundidade de $6 \mathrm{~m}$, uma na crista do talude e as demais aproximadamente a um quarto e a dois quartos da altura do talude, conforme ilustrado na Fig. 3.4. A coleta das amostras foi feita a cada $0,5 \mathrm{~m}$ de profundidade na sondagem ST-01, a cada $1,0 \mathrm{~m}$ de profundidade na ST-02 e a cada $1,5 \mathrm{~m}$ de profundidade na ST-03, conforme a homogeneidade do solo encontrado. As 
sondagens a trado foram realizadas também para se identificar a profundidade do contato entre os tipos de solo existentes no talude.

O perfil geológico-geotécnico do talude apresenta camada de aterro de argila, vermelha e branca, com cerca de 3,0 m de espessura sobreposta a solo residual siltoso, micáceo, marrom avermelhado, conforme indicado na Figura 3.4. Verificouse a existência de uma camada de argila com detritos vegetais com cerca de $20 \mathrm{~cm}$ de espessura entre os horizontes argiloso e o siltoso, que possibilitou classificar o horizonte argiloso como um aterro.

Um medidor de nível d'água foi construído no pé do talude com 4 metros de profundidade. O nível d'água localizava-se a $2,9 \mathrm{~m}$ de profundidade em relação ao pé do talude, no início de janeiro de 2005.

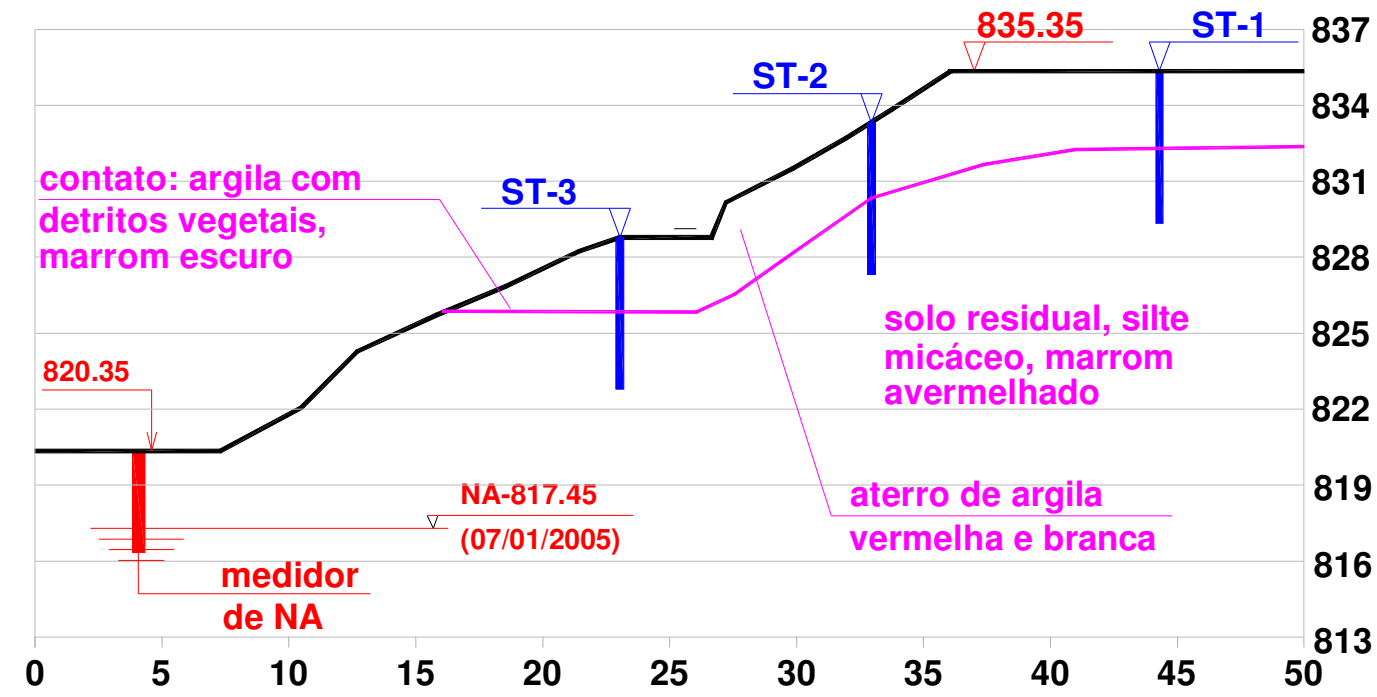

Figura 3.4: Perfil geológico-geotécnico

$\mathrm{O}$ aterro existente no campo experimental tem origem em sedimentos fluviais, incluindo argilitos, siltitos e arenitos da Formação São Paulo (TQs), do período Cenozóico (Terciário). O solo residual tem origem em quartzo-mica xistos do Complexo Pilar (PSpX), de origem pré-cambriana, de acordo com o Mapa Geológico 
do Estado de São Paulo apresentado na Figura 3.5 que foi elaborado pelo Instituto de Pesquisas Tecnológicas do Estado de São Paulo - IPT. A unidade geomorfológica em que está localizado o talude é de Colinas Pequenas com Espigões Locais, de acordo com o Mapa Geomorfológico do Estado de São Paulo, também elaborado pelo IPT.

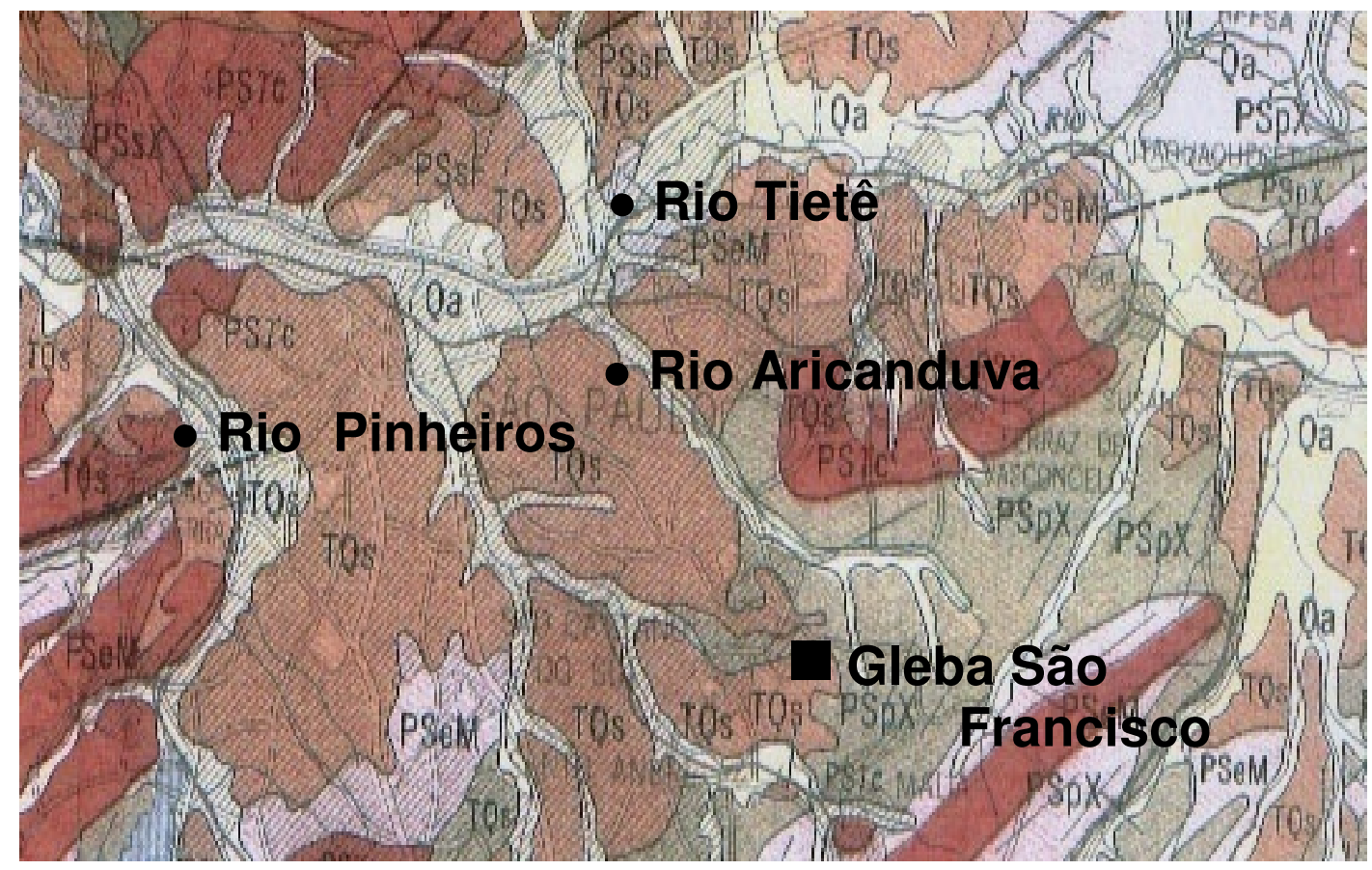

Figura 3.5: Mapa Geológico do Estado de São Paulo (IPT - Instituto de Pesquisas Tecnológicas do Estado de São Paulo)

Legenda

Qa

PSpX

PSeM

PSyc

TQs
- Sedimentos Aluvionares, incluindo areias inconsolidadas, argilas e Cascalheiras, do Cenozóico

- Quartzo-Mica Xistos do Complexo Pilar, do Pré-Cambriano

- Migmatitos de Estruturas Variadas do Complexo Embu, do PréCambriano

- Corpos para-autóctones e alóctones de composição granítica, Fácies Cantareira, do Pré-Cambriano

- Sedimentos fluviais incluindo argilitos, siltitos, arenitos da Formação São Paulo, do Cenozóico

Quatro blocos de solo indeformado foram retirados do talude a uma profundidade de 1,0 m do nível do terreno. Dois blocos foram retirados da crista do talude (BL-01 e BL-02) para amostragem do aterro argiloso e dois blocos (BL-03 e BL-04) foram 
retirados do pé do talude para amostragem do solo residual siltoso, conforme indicado na Figura 3.3. As fotos dos blocos podem ser vistas nas Fig. 3.6 e 3.7. Os blocos de solo residual foram retirados em trecho do talude fora do campo experimental devido a dificuldades técnicas para sua realização nesse local. As amostras deformadas e indeformadas de solo foram utilizadas para a realização de ensaios de caracterização e determinação de propriedades geotécnicas.

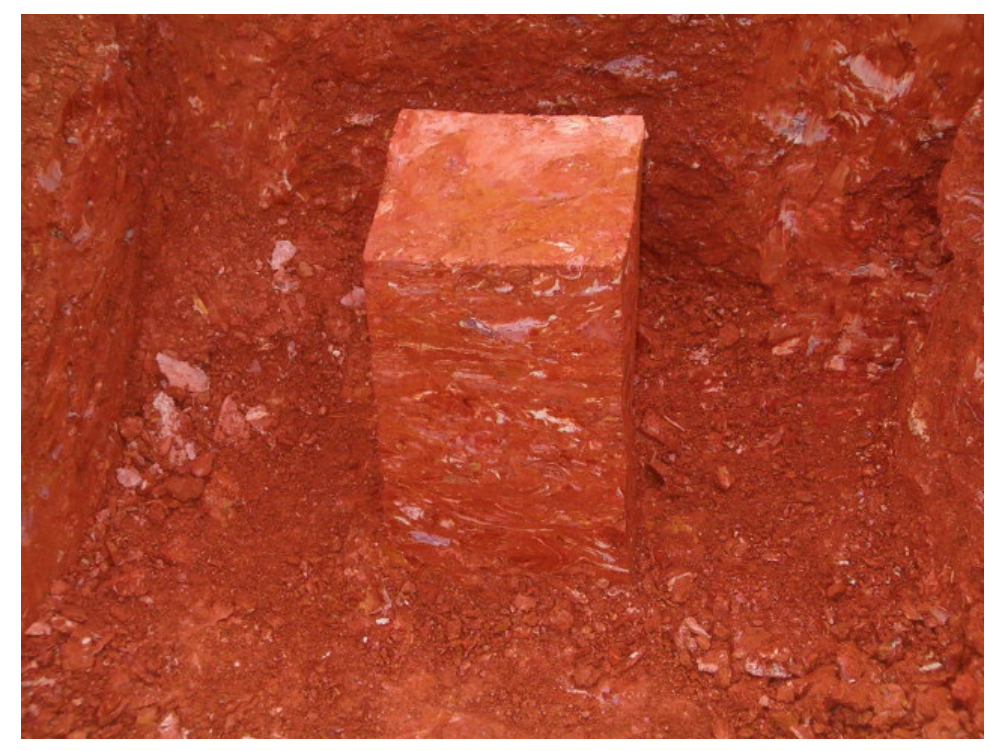

Figura 3.6: Bloco do aterro argiloso

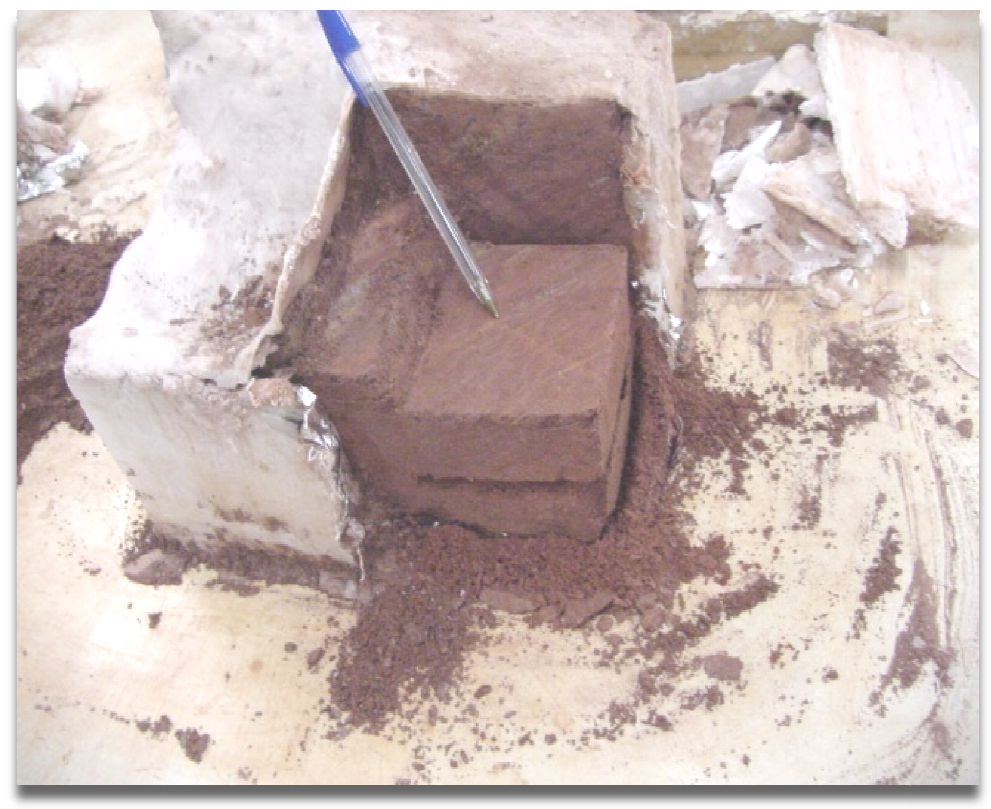

Figura 3.7: Bloco do solo residual siltoso 


\subsection{Caracterizações climática e pluviométrica}

O clima da cidade de São Paulo, onde se encontra o campo experimental, é Subtropical Úmido com Chuvas de Verão, tipo "Cwa" segundo a classificação de Koppen internacionalmente utilizada, típico da região sudeste brasileira, conforme descrito no site www.brasilturismo.com/saopaulo/. O clima subtropical úmido é dominado pela massa Tropical Atlântica, mas está sujeito à penetração da massa Polar Atlântica, principalmente no inverno.

A precipitação anual média é elevada, aproximadamente $1.350 \mathrm{~mm}$, não havendo estação seca bem definida. No verão a massa Tropical Atlântica provoca chuvas devido ao aquecimento do continente. No inverno, ocorre o avanço da massa Polar Atlântica. O encontro dessas massas de ar diferentes provoca chuvas frontais. Depois das chuvas, a massa Polar permanece estacionária e ocasiona ondas de frio de intensidade e duração variáveis.

\section{Análise da temperatura}

O clima subtropical apresenta as maiores amplitudes térmicas entre os climas brasileiros: os verões são moderadamente quentes e os invernos são frios. O mês mais quente, janeiro, tem temperatura média de $21^{\circ} \mathrm{C}$ e o mês mais frio, julho, de $14^{\circ} \mathrm{C}$. A menor temperatura já registrada oficialmente em São Paulo foi de $-2,1^{\circ} \mathrm{C}$, em dois de agosto de 1955 no Mirante de Santana (Zona Norte). A máxima registrada foi de $35,3^{\circ} \mathrm{C}$, no dia 15 de novembro de 1985 também no Mirante de Santana.

Analisam-se a seguir os registros de temperatura da Estação da Água Funda, localizada na Zona Sul de São Paulo. Esta estação meteorológica foi escolhida por apresentar dados com período de retorno maior que os de outras, 70 anos. Os registros indicam temperaturas mínimas e máximas absolutas de $-1^{\circ} \mathrm{C}$ e $36^{\circ} \mathrm{C}$, respectivamente, conforme indicado na Tabela 3.2. Nos 70 anos de registros da estação, os últimos 14 anos (período 1994-2007), apresentaram sete dos doze meses com temperaturas recorde, ou $58 \%$ dos meses. Há um indício de que as 
temperaturas vêem se elevando ou que há um ciclo de elevação de temperaturas em andamento. De outro lado, no mesmo período de 14 anos (1994-2007), ou 20\% do tempo, não há registro algum de temperaturas mínimas recorde, o que corrobora a observação de que há mudanças climáticas em andamento.

Tabela 3.2: Temperaturas máximas e mínimas registradas na Estação da Água Funda localizada na Zona Sul de São Paulo

\begin{tabular}{|c|c|c|c|c|c|c|c|c|c|c|c|c|c|}
\hline & Jan & Fev & Mar & Abr & Mai & Jun & Jul & Ago & Set & Out & Nov & Dez & Anual \\
\hline $\begin{array}{c}\text { Máxima } \\
\text { Média }{ }^{\circ} \mathrm{C}\end{array}$ & 27 & 28 & 27 & 25 & 23 & 22 & 21 & 23 & 23 & 25 & 26 & 26 & 24 \\
\hline $\begin{array}{c}\text { Mínima } \\
\text { Média }{ }^{\circ} \mathrm{C}\end{array}$ & 19 & 19 & 18 & 17 & 15 & 13 & 12 & 13 & 14 & 16 & 17 & 18 & 16 \\
\hline $\begin{array}{c}\text { Máxima } \\
\text { Abs. }{ }^{\circ} \mathrm{C}^{\star}\end{array}$ & 35 & 35 & 35 & 33 & 31 & 29 & 30 & 33 & 35 & 35 & 36 & 36 & 33 \\
\hline $\begin{array}{c}\text { Mínima } \\
\text { Abs. }{ }^{\circ} \mathrm{C}^{\star}\end{array}$ & 10 & 10 & 10 & 4 & 1 & -1 & -1 & -1 & 0 & 5 & 5 & 8 & 3 \\
\hline
\end{tabular}

\section{Análise da pluviometria}

A partir de dados coletados no site do SIGRH - Sistema de Informações para o Gerenciamento de Recursos Hídricos do Estado de São Paulo, realizou-se estudo da pluviometria da cidade de São Paulo, onde se localiza o talude experimental. Para este estudo foram selecionados dados de precipitação de dois postos pluviométricos.

Dados do Posto Pluviométrico da Luz localizado no centro de São Paulo e distante 24 quilômetros do campo experimental foram utilizados por serem os mais completos da região (registros de 116 anos). Dados do Posto Pluviométrico Jardim Centenário localizado na Bacia do Rio Aricanduva foram utilizados por serem os mais próximos do campo experimental disponíveis, oito quilômetros de distância. Neste posto há registros de apenas 22 anos. Os registros do Posto da Luz, utilizados nesta análise, iniciam-se em 1904 e terminam em 2003 (100 anos), e os do Posto Jardim Centenário iniciam-se em 1973 e terminam em 1992 (20 anos).

Comparando-se as pluviometrias médias dos dois postos verifica-se que a região da bacia do Rio Aricanduva apresenta precipitações médias maiores que o centro da 
cidade de São Paulo. A precipitação anual média no posto Jd. Centenário é de 1.463 mm, e no Posto da Luz de $1.351 \mathrm{~mm}$, conforme apresentado nas Tabelas 3.3 e 3.4. Da mesma forma a precipitação mensal média no posto Jd. Centenário é de 124 $\mathrm{mm}$, e no Posto da Luz de $115 \mathrm{~mm}$. A precipitação diária máxima mensal média no posto Jd. Centenário é de $35 \mathrm{~mm}$, e no Posto da Luz de $34 \mathrm{~mm}$. E a precipitação acumulada máxima em cinco dias mensal média (para meses com precipitação maior ou igual a $200 \mathrm{~mm}$ ) no posto Jd. Centenário é de $122 \mathrm{~mm}$, e no Posto da Luz de $116 \mathrm{~mm}$. Supõe-se que a Bacia do Aricanduva seja mais chuvosa que o centro de São Paulo porque é mais próxima da Serra do Mar, que gera frentes de umidade, aproximadamente $20 \mathrm{~km}$, do que o Posto da Luz que dista cerca $40 \mathrm{~km}$ da Serra do Mar.

Tabela 3.3: Dados do Posto Pluviométrico da Luz referentes ao período de 100 anos decorridos entre 1904 e 2003

\begin{tabular}{|c|c|c|c|c|c|c|c|c|}
\hline \multicolumn{9}{|c|}{ Precipitação (mm) } \\
\hline & \multirow{2}{*}{ Anual } & \multirow{2}{*}{ Mensal } & \multicolumn{4}{|c|}{ Mensal } & \multirow{2}{*}{$\begin{array}{c}\text { Diária Máx } \\
\text { Mensal }\end{array}$} & \multirow{2}{*}{$\begin{array}{l}\text { Acumulada } \\
\text { Máx. } 5 \text { dias* }\end{array}$} \\
\hline & & & Dez & Jan & Fev & Mar & & \\
\hline máxima & 2.271 & 600 & 453 & 552 & 600 & 424 & 147 & 246 \\
\hline média & 1.351 & 115 & 185 & 239 & 218 & 167 & 34 & 116 \\
\hline mínima & 512 & 0 & 20 & 89 & 30 & 25 & 0 & 42 \\
\hline desv. padrão & 305 & 94 & 85 & 93 & 99 & 79 & 23 & 37 \\
\hline
\end{tabular}

* - mensal, para meses com precipitação maior ou igual a $200 \mathrm{~mm}$.

Tabela 3.4: Dados do Posto Pluviométrico Jd. Centenário referentes ao período de 20 anos decorridos entre 1973 e 1992

\begin{tabular}{|c|c|c|c|c|c|c|c|c|}
\hline \multicolumn{9}{|c|}{ Precipitação $(\mathrm{mm})$} \\
\hline & Anual & Mensal & \multicolumn{5}{|c|}{ Mensal } & Diária Máx \\
Mensal & $\begin{array}{c}\text { Acumulada } \\
\text { Máx. 5 dias }\end{array}$ \\
\cline { 4 - 9 } & & & Dez & Jan & Fev & Mar & Mén \\
\hline máxima & 2.007 & 520 & 520 & 396 & 337 & 434 & 115 & 217 \\
\hline média & 1.463 & 124 & 207 & 256 & 192 & 163 & 35 & 122 \\
\hline mínima & 875 & 1 & 92 & 141 & 10 & 75 & 0 & 54 \\
\hline Desv. padrão & 306 & 94 & 97 & 78 & 97 & 86 & 22 & 38 \\
\hline
\end{tabular}

* - mensal, para meses com precipitação maior ou igual a $200 \mathrm{~mm}$. 
De outro lado, observa-se que as precipitações máximas são maiores na Luz do que na Bacia do Rio Aricanduva. A precipitação anual máxima na Luz é $2.271 \mathrm{~mm}$ e na Bacia do Aricanduva $2.007 \mathrm{~mm}$. As precipitações mensal máxima, diária máxima mensal e acumulada máxima em cinco dias mensal também são maiores na Luz do que na Bacia do Aricanduva conforme apresentado nas Tabelas 3.3 e 3.4. Há uma exceção a essa constatação verificada no mês de dezembro, conforme indicado nas tabelas acima.

A região da Luz apresenta precipitações máximas $17 \%$ maiores que as máximas registradas na Bacia do Aricanduva. Provavelmente, isso se deve ao período de retorno dos dados da Estação da Luz ser cinco vezes maior que os da Bacia do Aricanduva. Registros com período de retorno maior geralmente apresentam precipitações máximas maiores e mínimas menores do que registros com período de retorno menor.

Comparando-se as precipitações mínimas anuais nos dois postos verifica-se que na Luz a mínima anual do período de 100 anos (512 mm) é menor que a mínima anual na Bacia do Aricanduva $(875 \mathrm{~mm})$ que tem período de retorno de 20 anos.

\section{Análise da variação da pluviometria ao longo do tempo}

A análise da variação da pluviometria ao longo do tempo foi feita por meio de análises da distribuição da precipitação anual. Para isso foram indicadas na Figura 3.8 as precipitações anuais nos dois postos pluviométricos. Além disso, foram indicados os valores máximos, médios e mínimos de precipitação anual para cada década, iniciando-se pela década de 1904 a 1913, até a década de 1994 a 2003, referentes ao Posto da Luz. Para o Posto Jd. Centenário são apresentadas as precipitações anuais máximas, médias e mínimas das duas décadas disponíveis, 1973 a 1982 e 1983 a 1992. São apresentadas ainda, para o Posto da Luz, regressões lineares para as precipitações anuais máxima, média e mínima, para o período de 100 anos indicado. 


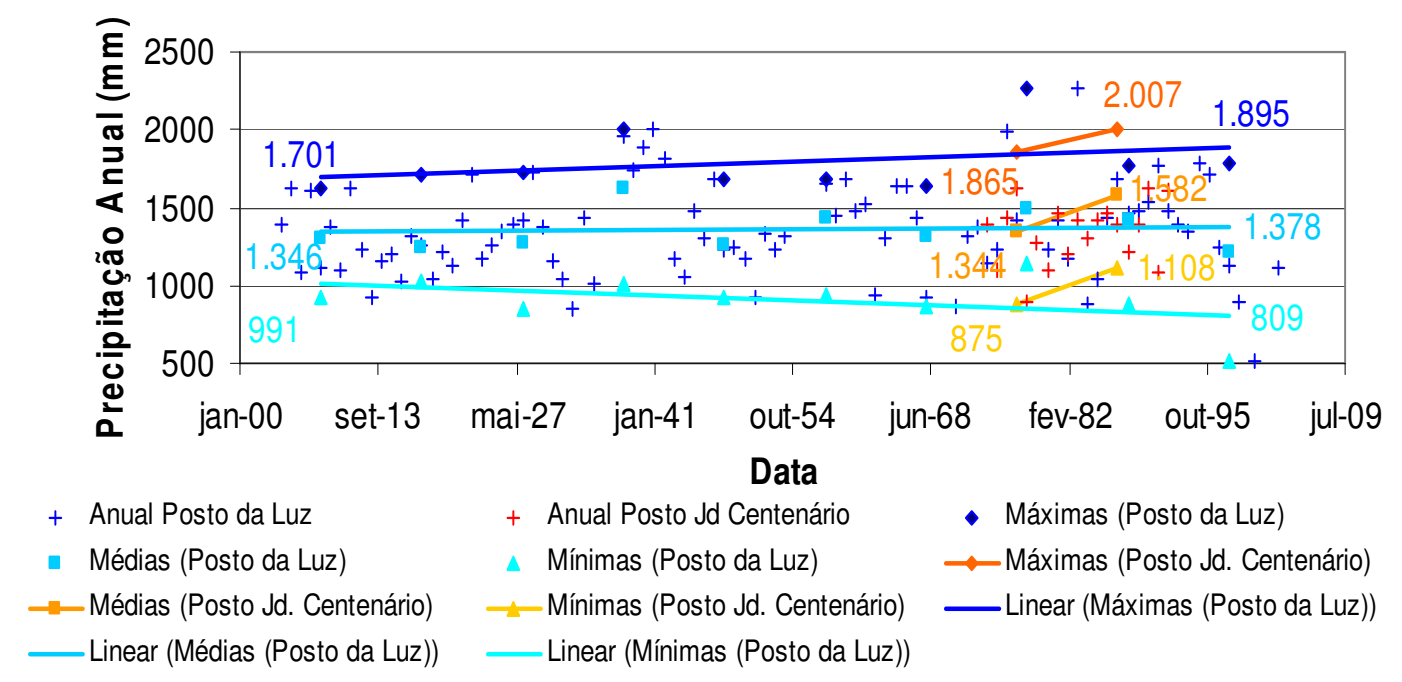

Figura 3.8: Precipitação anual nos Postos Pluviométricos da Luz (1904 a 2003) e Jardim Centenário (1973 a 1992), e precipitações anuais máximas, médias e mínimas por década.

Os resultados das regressões lineares para o Posto da Luz indicam elevação de 11 \% das precipitações máximas anuais, partindo-se de $1.701 \mathrm{~mm}$ na década de 1904 a 1913 e atingindo $1.895 \mathrm{~mm}$ na década de 1994 a 2003. Os resultados indicam também queda de 28 \% das precipitações mínimas anuais, partindo-se de $991 \mathrm{~mm}$ na década de 1904 a 1913 e atingindo 809 mm na década de 1994 a 2003. A precipitação média anual variou pouco, cerca de $2 \%$, de $1.346 \mathrm{~mm}$ na década de 1904 a 1913 e para 1.378 mm na década de 1994 a 2003.

A análise dos dados da pluviometria do Posto Jd. Centenário indica uma elevação significativa nas precipitações anuais máximas, médias e mínimas entre a década de 1973 a 1982 e a década de 1983 a 1992, sendo provavelmente uma variação normal que ocorre de uma década para outra, conforme verificado nos dados do Posto da Luz.

\section{Análise da intensidade horária das precipitações}

A intensidade horária das precipitações é fator importante entre os condicionantes de deflagração de escorregamentos de taludes. Há diversas equações IDF 
(intensidade - duração - freqüência) disponíveis para a Região Metropolitana de São Paulo (RMSP), como as determinadas por Paulo Wilken, Antonio Garcia Occhipinti e Felix Mero. A equação desenvolvida pelo último autor é a que fornece maiores valores de precipitação para durações entre 1 e 24 horas:

$$
\mathrm{i}_{\mathrm{t}, \mathrm{T}}=\mathrm{t}^{-0,821}[16,14-5,65 \cdot \ln [\mathrm{T} /(\mathrm{T}-1)]
$$

onde: $\mathrm{i}=$ intensidade da chuva $\mathrm{em} \mathrm{mm} / \mathrm{min}$

$\mathrm{t}=$ duração da chuva em minutos

$\mathrm{T}=$ período de retorno em anos

A equação IDF desenvolvida por Mero apresenta resultados compatíveis com os resultados das análises apresentadas anteriormente neste trabalho. Considerandose uma chuva intensa com duração de 24 horas e com período de retorno de 100 anos, a equação fornece uma precipitação horária de $6,5 \mathrm{~mm} / \mathrm{h}$ e precipitação total em 24 horas de 156 mm, conforme indicado na Tabela 3.5 e na Figura 3.9. Valor próximo do resultado de $147 \mathrm{~mm}$ obtido na análise realizada anteriormente apresentado na Tabela 3.3, para precipitação diária máxima.

Tabela 3.5: Equação IDF (RMSP)

\begin{tabular}{|c|c|}
\hline \multicolumn{2}{|c|}{ Equação IDF para a RMSP } \\
\hline $\begin{array}{c}\text { Duração da } \\
\text { Chuva }(\mathrm{h})\end{array}$ & $\begin{array}{c}\text { Precipitação } \\
\text { Horária }(\mathrm{mm} / \mathrm{h})\end{array}$ \\
\hline 1 & 88 \\
\hline 2 & 50 \\
\hline 6 & 20 \\
\hline 12 & 11 \\
\hline 24 & 7 \\
\hline
\end{tabular}

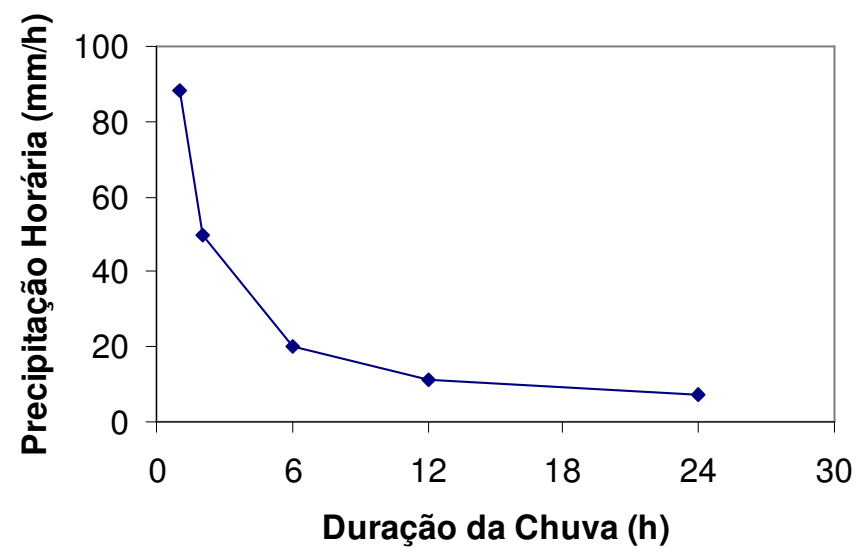

Figura 3.9: Curva IDF (RMSP) 


\subsection{Implantação do experimento}

As obras de implantação do experimento iniciaram-se em dezembro de 2004 com a construção de cerca de arame farpado em torno do campo experimental e pelo corte da vegetação existente, capim, na porção do talude a ser recoberta com argamassa. Em seguida foi aplicado o revestimento superficial de argamassa de cimento e areia (1:3) com espessura média de $3 \mathrm{~cm}$. Na crista do talude o revestimento com argamassa tem cerca de $10 \mathrm{~m}$ de comprimento, conforme indicado na Figura 3.10.

A instrumentação instalada no talude consistiu de: um pluviômetro, um medidor de nível d'água construído no pé do talude, e 25 tubos tensiométricos. Os tubos foram instalados em duas linhas simétricas, perpendiculares às curvas de nível, uma na porção do talude com vegetação, cujos tubos tensiométricos foram nomeados de $\mathrm{A}$ a $\mathrm{M}$, e a outra na porção argamassada, cujos tubos foram numerados de 1 a 13 . As profundidades em que foram instalados os tubos tensiométricos foram 0,5 $\mathrm{m}, 1,5 \mathrm{~m}$, 3,0 m e 4,0 m. Os tensiômetros instalados na porção argamassada do talude ficam no centro da faixa de $10 \mathrm{~m}$ de largura, ou a cinco metros dos limites da faixa. Os tensiômetros instalados na porção com vegetação ficam no centro da faixa de seis metros, ou a três metros do limite da faixa.

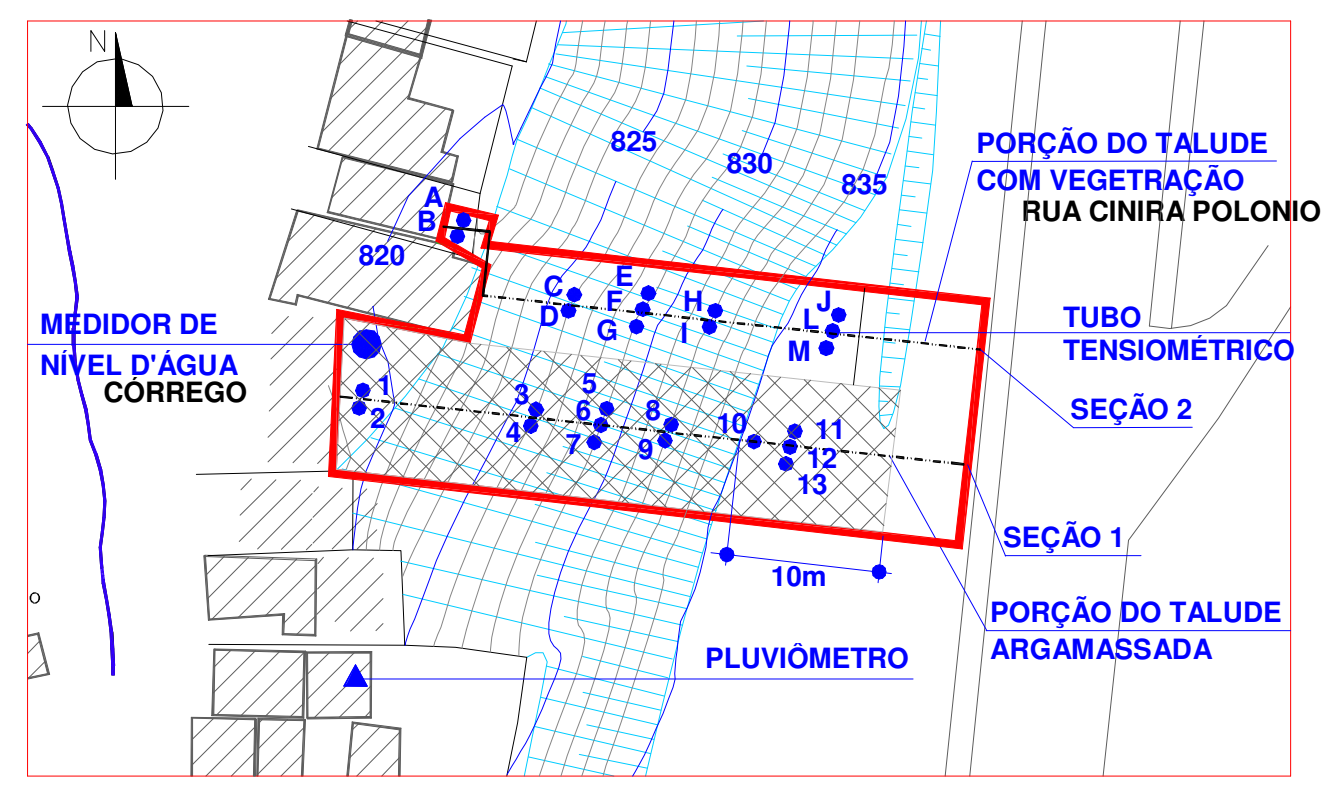

Figura 3.10: Planta de implantação da instrumentação 
Foram instalados 13 tubos tensiométricos na porção argamassada do talude, indicada pela Seção 1. Foram quatro na crista (tubos 10 a 13), nas profundidades de 0,5m, 1,5 m (2 unidades) e 3,0 m; dois entre a crista e o meio do talude (tubos 8 e 9), nas profundidades de $1,5 \mathrm{~m} \mathrm{e} 3,0 \mathrm{~m}$; três no meio do talude (tubos 5 a 7 ), nas profundidades de $0,5 \mathrm{~m}, 1,5 \mathrm{~m}$ e 3,0 m; dois entre o meio e o pé do talude (tubos $3 \mathrm{e}$ 4), nas profundidades de $1,5 \mathrm{~m} \mathrm{e} 3,0 \mathrm{~m}$; e dois no pé do talude (tubos 1 e 2), nas profundidades de $0,5 \mathrm{~m}$ e $1,5 \mathrm{~m}$. A seção transversal do terreno que indica a posição de instalação dos tensiômetros na porção argamassa do talude, denominada está apresentada na Figura 3.11.

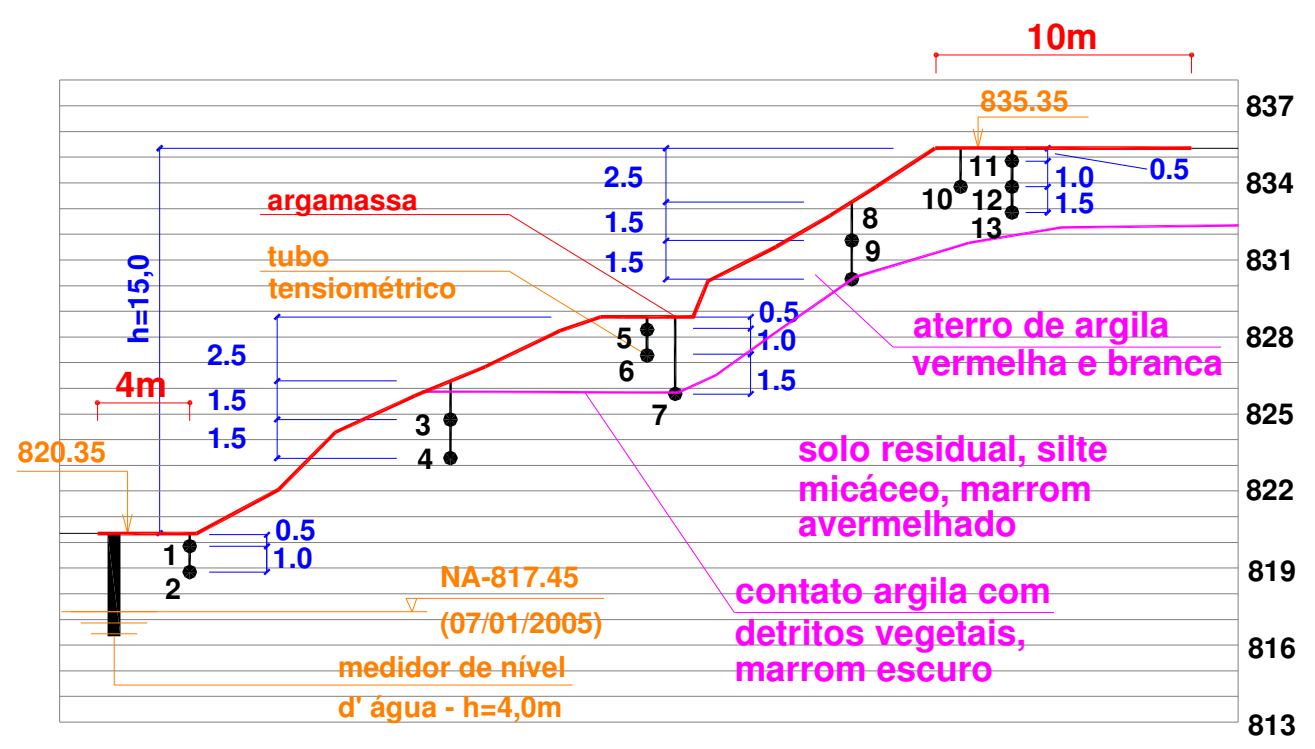

Figura 3.11: Seção 1 - Instrumentação na porção argamassada do talude

Na porção com vegetação do talude, Seção 2, foram instalados 12 tensiômetros, sendo três na crista (tubos J, L e M), nas profundidades de 0,5m, 1,5 m e 4,0 m (instalado com inclinação de $20^{\circ} \mathrm{com}$ a horizontal); dois entre a crista e o meio do talude (tubos $\mathrm{H}$ e I), nas profundidades de $1,5 \mathrm{~m} \mathrm{e} \mathrm{3,0} \mathrm{m;} \mathrm{três} \mathrm{no} \mathrm{meio} \mathrm{do} \mathrm{talude}$ (tubos $\mathrm{E}, \mathrm{F}$ e $\mathrm{G}$ ), nas profundidades de $0,5 \mathrm{~m}, 1,5 \mathrm{~m} \mathrm{e} \mathrm{3,0} \mathrm{m}$; dois entre o meio e 0 pé do talude (tubos C e D), nas profundidades de $1,5 \mathrm{~m}$ e $3,0 \mathrm{~m}$; e dois no pé do talude (tubos $A$ e B), nas profundidades de 0,5 m e 1,5 m. A seção transversal do terreno com a posição de instalação dos tensiômetros na porção com vegetação do talude está apresentada na Figura 3.12. 


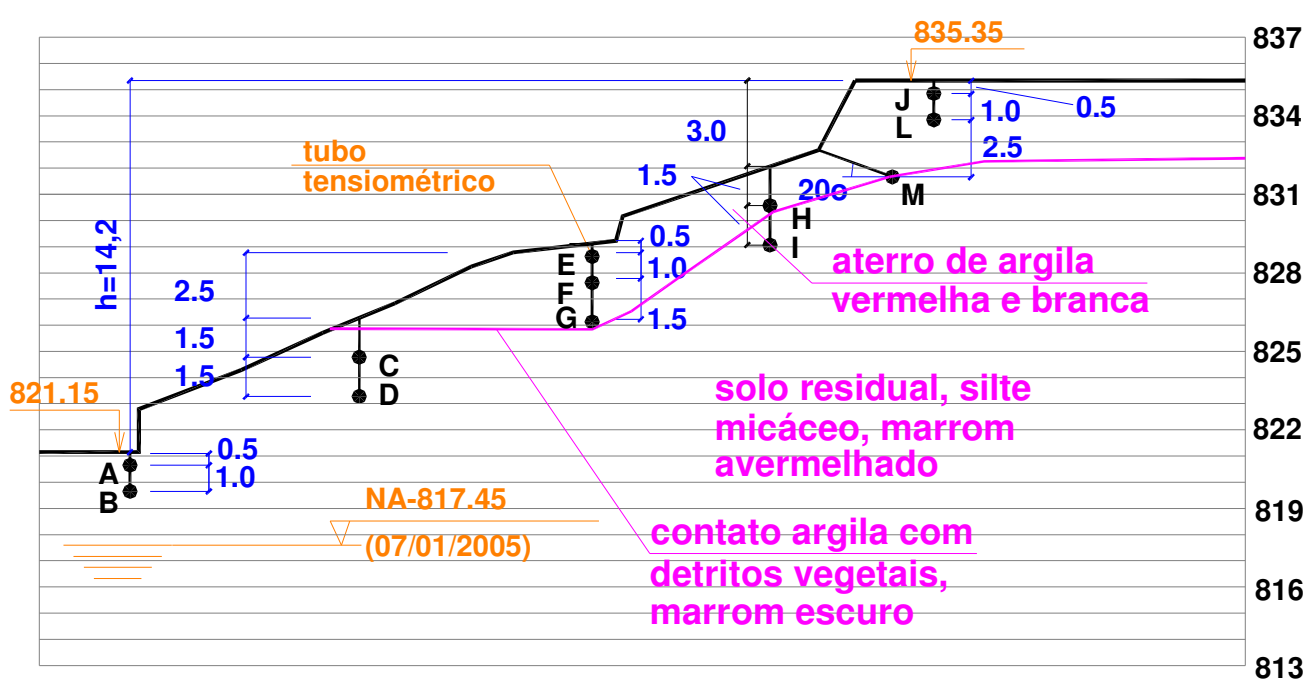

Figura 3.12: Seção 2 - Instrumentação na porção do talude com vegetação

\subsubsection{Descrição dos tensiômetros e tubos tensiométricos}

Os tensiômetros utilizados para leitura dos tubos tensiométricos são denominados "tensímetro digital de punção" e "tensímetro analógico de punção". A principal característica e vantagem é usar um único transdutor de pressão ou vacuômetro analógico para se efetuar leituras nos tubos tensiométricos. O tensímetro possui uma agulha hipodérmica que possibilita a conexão a cada tubo tensiométrico, conforme se pode ver nas Figuras 3.13 e 3.14 .
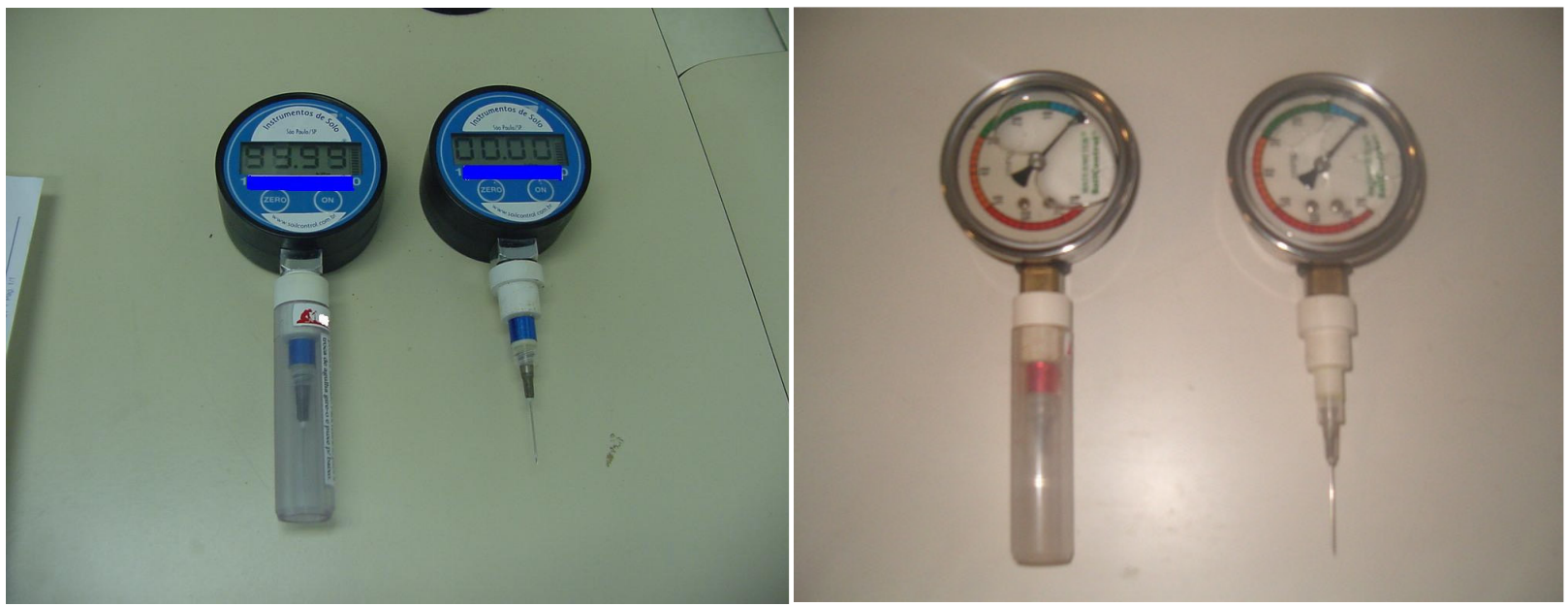

Figura 3.13: Tensímetro digital de punção

Figura 3.14: Tensímetro analógico de punção 
O tensímetro digital é composto por uma agulha hipodérmica, uma pequena câmara de acesso, uma placa metálica que se deforma quando da aplicação do vácuo e um "strain gauge" encostado na placa metálica. Ao se deformar, o "strain gauge" provoca alteração da corrente elétrica, e esse dado é enviado ao processador (conversor analógico digital). O processador, localizado em uma placa de circuito eletrônico, tem a função de alimentar o "strain gauge", receber e processar a corrente enviada por ele, e convertê-la em uma unidade de medida de engenharia. Finalmente, o processador envia uma corrente elétrica a um visor de cristal líquido que a converte em leitura. $O$ tensímetro analógico compõe-se de um vacuômetro analógico conectado a uma agulha hipodérmica.

As vantagens da utilização deste tipo de instrumento são: a redução de custos na aquisição dos instrumentos, a redução de erros causados pela dispersão das leituras nos manômetros ou transdutores, e a redução de problemas operacionais como o vandalismo. Apesar de ser um instrumento simples, não há registros de sua aplicação na engenharia geotécnica, embora seja comum na aplicação agrícola.

Os tubos tensiométricos utilizados têm comprimentos de $0,5 \mathrm{~m}, 1,5 \mathrm{~m}$ e 3,0m. Os dois últimos comprimentos podem ser vistos na Figura 3.15. Seu diâmetro é de $20 \mathrm{~mm}$ e é composto por uma pedra porosa na extremidade inferior, tubo de PVC na maior parte de seu comprimento, tubo transparente de acrílico com $15 \mathrm{~mm}$ de diâmetro nos $10 \mathrm{~cm}$ finais, e tampa de silicone no topo. A tampa de silicone e o trecho em acrílico são recobertos com tubo e CAPs de PVC com $20 \mathrm{~mm}$ de diâmetro, para proteção no campo. $O$ trecho de $10 \mathrm{~cm}$ em tubo de acrílico fica para fora do terreno e permite visualizar o nível d'água no tubo, indicando a necessidade de se adicionar água no tubo, conforme pode ser visto na Figura 3.16.

As leituras de poro-pressão de água são realizadas através do puncionamento da tampa de silicone dos tubos tensiométricos pela agulha hipodérmica do tensímetro. Há uma perfeita vedação entre a tampa e o tubo, e entre a tampa e a agulha, impedindo o vazamento de pressão. Dentro do tubo tensiométrico há água destilada que se encontra sob pressão negativa, em equilíbrio com a sucção do solo. Ao se introduzir a agulha do tensímetro no tubo o ar existente na câmara do instrumento 
também estará submetido a essa mesma pressão e será registrada pelo vacuômetro ou transdutor de pressão.

Há uma limitação física do equipamento utilizado para medição de sucção, tubo tensiométrico, referente a medições em profundidades maiores do que as realizadas, $3,0 \mathrm{~m}$. Isso se deve ao fato de que o tubo tensiométrico convencional utilizado apresenta cavitação para sucções maiores que $90 \mathrm{kPa}$. De acordo com Marinho e Chandler (1995) e Marinho (1997) a cavitação ocorre por existirem núcleos gasosos oclusos no interior do tubo tensiométrico que não resistem às tensões de tração geradas por elevadas sucções. Portanto, a sucção máxima que um tubo com 3,0 m de comprimento, instalado na vertical, pode medir é cerca de $60 \mathrm{kPa}(90-30 \mathrm{kPa})$. Tubos mais longos apresentam medições máximas ainda menores, o que limita os resultados de um monitoramento. $E$ há ainda outra dificuldade, que se refere à perfuração e instalação de tubos tensiométricos em profundidades maiores que 3,0 $\mathrm{m}$.

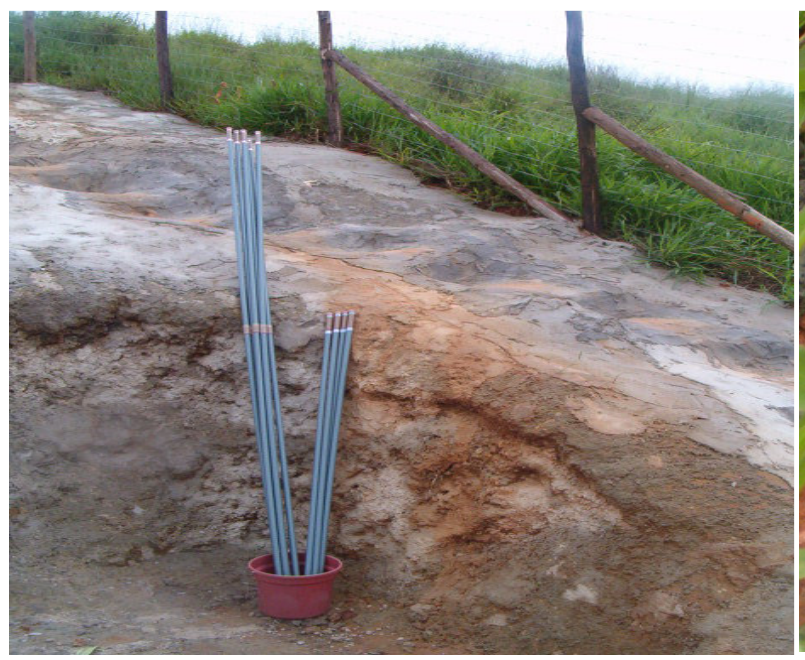

Figura 3.15: Tubos tensiométricos de 1,5 e 3,0 m de comprimento

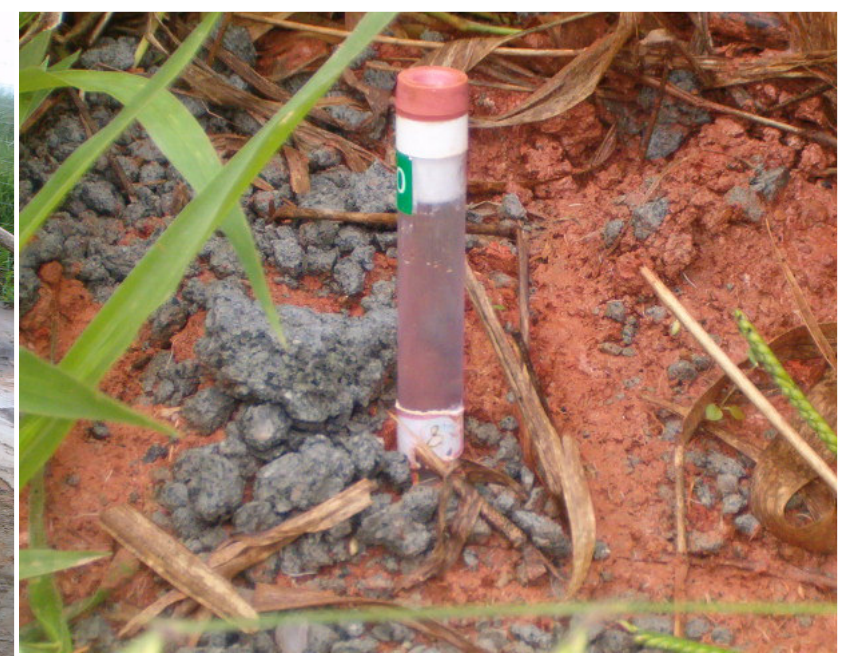

Figura 3.16: Detalhe da parte superior do tubo tensiométrico 


\subsubsection{Instalação dos tubos tensiométricos}

A instalação dos tubos tensiométricos foi feita escavando-se furo no terreno com trado helicoidal de $25 \mathrm{~mm}$ de diâmetro, com o mesmo comprimento do tubo tensiométrico. Preparou-se antecipadamente uma pasta com o solo retirado da superfície do talude umedecendo-o até atingir umidade maior que o limite de liquidez. Introduziu-se a pasta dentro do furo e, após seu preenchimento, o tubo tensiométrico foi inserido no furo.

Após a inserção do tubo compactou-se manualmente solo na superfície do terreno junto ao tubo, elevando o nível do terreno em alguns centímetros a fim de evitar o acúmulo de água de chuva no local. Na porção argamassada do talude aplicou-se argamassa entorno do tubo instalado. A saturação das pedras porosas dos tubos foi feita pelo preenchimento dos tubos com água destilada uma hora antes da instalação em campo. 


\section{RESULTADOS E ANÁLISES DOS ENSAIOS LABORATORIAIS E DE CAMPO}

\subsection{Ensaios para análise do funcionamento do tensímetro}

\subsubsection{Ensaios com tensímetro em laboratório}

Foram feitos experimentos com o tensímetro em laboratório com o objetivo de conhecer seu funcionamento e de comparar o resultado de suas leituras com o de outros tipos de tensiômetros.

Os experimentos consistiram na compactação de amostras deformadas do aterro e do solo residual retiradas do campo experimental, em cilindros de Proctor Intermediário; na instalação de três tipos de tensiômetros em cada cilindro: tensiômetro analógico, tensiômetro digital, e tubo tensiométrico para leitura com tensímetro conforme mostrado na Figura 4.1. As superfícies superiores dos cilindros foram recobertas com papel filme e sobre ele aplicado papel de alumínio, com o objetivo de reduzir a perda de umidade do solo para o ambiente. Em seguida foram registradas as leituras dos três instrumentos durante as fases do experimento.

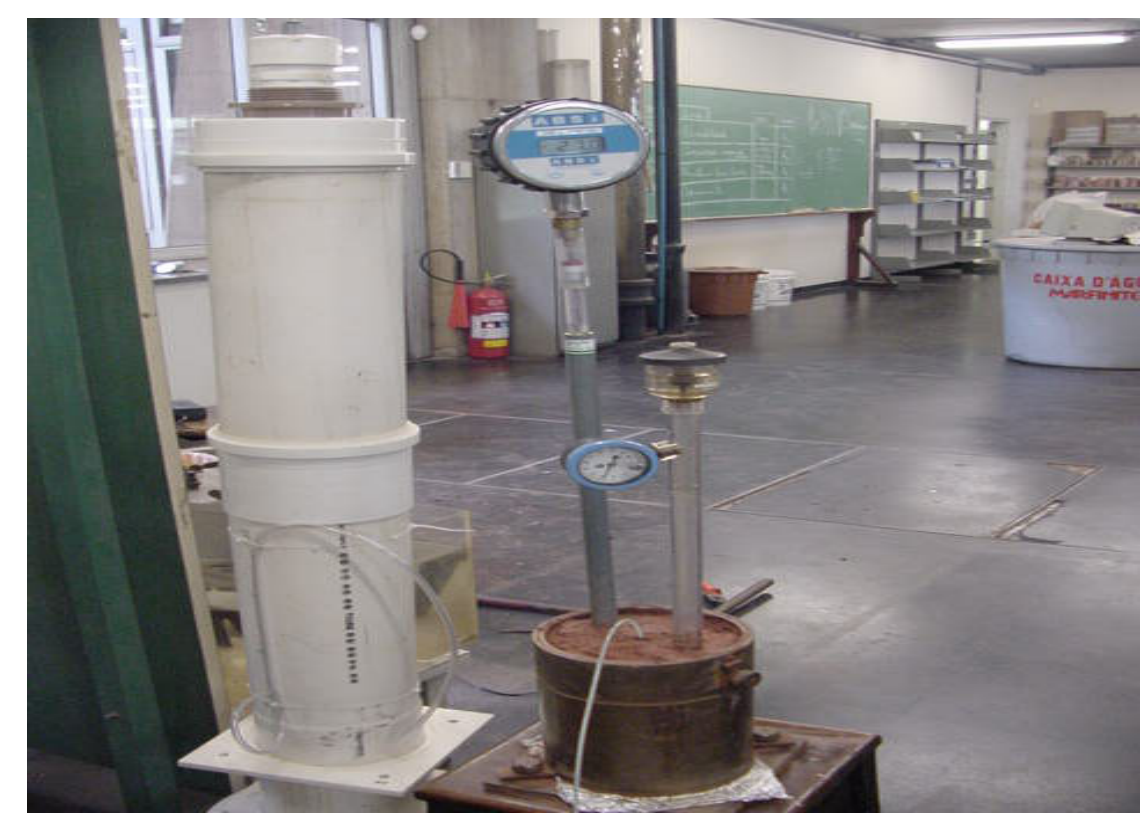

Figura 4.1: Experimento com tensímetro fornecido pelo segundo fabricante, ver parte superior da foto, realizado em laboratório 


\subsubsection{Em solo residual}

Foram compactados $7.187 \mathrm{~g}$ de solo residual siltoso em cilindro de Proctor com volume de $4.040 \mathrm{~cm}^{3}$ resultando em peso específico de $17,8 \mathrm{kN} / \mathrm{m}^{3}$, praticamente igual ao peso específico natural do material em campo, $17,9 \mathrm{kN} / \mathrm{m}^{3}$. O material foi compactado com 19,2\% de umidade, acima da umidade natural, $14,1 \%$, resultando em um grau de saturação de $63,3 \%$. A compactação foi feita em seis camadas com aplicação de 25 golpes de soquete de $2,5 \mathrm{~kg}$ em cada camada.

Os furos para instalação dos tensiômetros foram feitos de maneira a que o centro das pedras porosas ficasse no ponto médio da altura do cilindro, que tem altura 22,8 $\mathrm{cm}$. O furo para a instalação do tensiômetro digital foi feito deixando-se uma haste com 6,3 mm de diâmetro dentro do cilindro quando da compactação do solo, e retirando-se a haste após a compactação. Os furos para a instalação dos dois demais tensiômetros foram feitos com furadeira e broca de 2,0 cm de diâmetro, e com trado helicoidal de $2,5 \mathrm{~cm}$ de diâmetro.

A instalação dos tensiômetros foi feita utilizando-se pasta de água e solo, do mesmo material compactado, colocado dentro dos furos e ao redor das pedras porosas. Após a instalação dos tensiômetros a superfície superior do cilindro foi vedada com filme de PVC e papel alumínio conforme descrito anteriormente.

\section{Ensaio 1 - Homogeneização da umidade da pasta com o material compactado}

Em seguida à instalação dos instrumentos, as leituras dos tensiômetros passaram a ser registradas, e são apresentadas na Figura 4.2, que refletem a homogeneização da umidade da pasta com material compactado.

O tensiômetro analógico registrou leitura de estabilização da suç̧ão (30 kPa) em menor tempo que os demais, 7 minutos. O tensiômetro digital levou 30 minutos para atingir os $30 \mathrm{kPa}$ e se estabilizou em $31,7 \mathrm{kPa}$ depois de 23 horas. $\mathrm{O}$ tensímetro foi o instrumento que levou maior tempo para atingir $30 \mathrm{kPa}, 1 \mathrm{~h} 45 \mathrm{~min}$. E, depois de 23 horas apresentou leitura de $32,5 \mathrm{kPa}$. 
Pode-se concluir que: (a) o tensiômetro analógico apresentou o menor tempo de estabilização entre os instrumentos analisados; (b) o tensímetro levou cerca de três vezes mais tempo para estabilizar que o tensiômetro digital; (c) o tensiômetro digital e o tensímetro apresentaram diferença menor que $\mathbf{1 ~} \mathbf{k P a}$ em suas leituras de estabilização após 23 horas; (d) o sistema de agulha e tampa de silicone do tensímetro não apresentou perda de pressão durante as 23 horas do ensaio. Os demais instrumentos também não apresentaram variações significativas de pressão durante o ensaio.

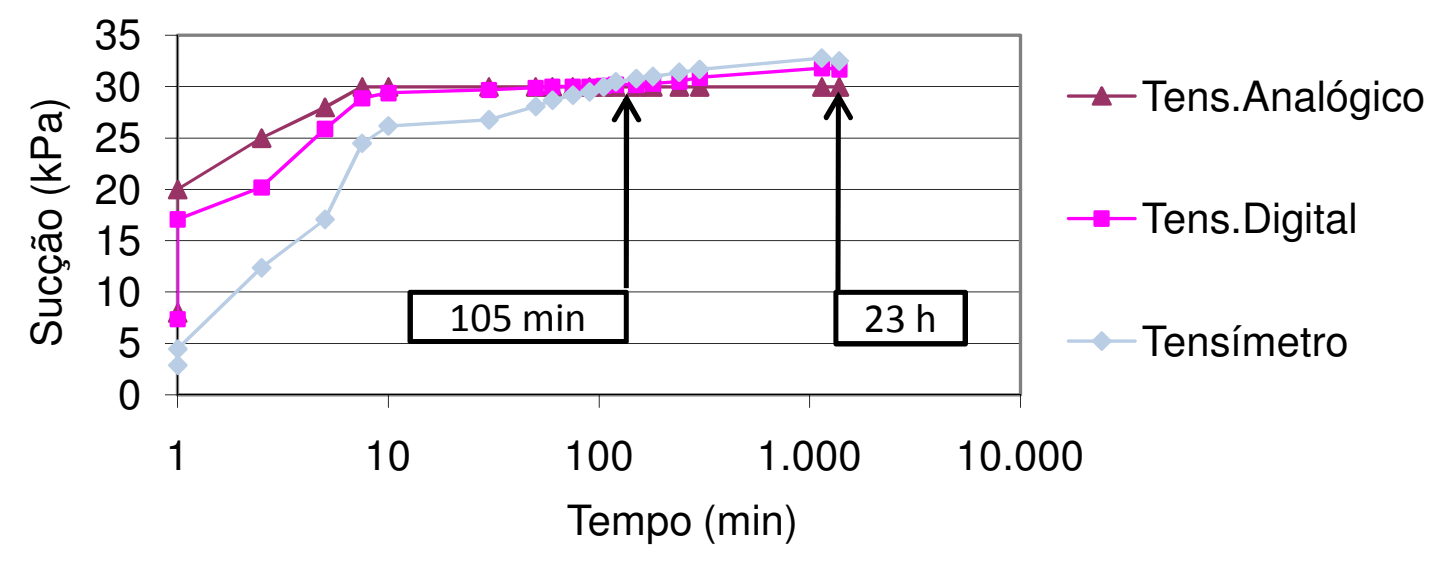

Figura 4.2: Ensaio 1: Homogeneização da umidade da pasta com o material compactado

\section{Ensaio 2 - Retirada e recolocação do tensímetro no tubo tensiométrico}

Este ensaio foi realizado no dia seguinte ao dia do Ensaio 1 e consistiu na retirada do tensímetro do tubo tensiométrico; e na sua recolocação (punção) um minuto após a retirada. As leituras dos instrumentos foram registradas nas 18 horas seguintes, conforme mostra a Figura 4.3.

Verificou-se queda de cerca de $\mathbf{4} \mathbf{k P a}$ na leitura do tensímetro, de 32,5 para 28,7 kPa, logo após a inserção da agulha.

Após $\mathbf{3 0}$ minutos as leituras de todos os equipamentos estabilizaram em $31 \mathrm{kPa}$ de sucção. A partir desse tempo as leituras no tensímetro e no tensiômetro digital 
apresentaram pequena elevação, porém as leituras no tensiômetro analógico permaneceram constantes.

Conclui-se que: (a) o processo de retirada e puncionamento do tensímetro na tampa de silicone do tubo tensiométrico provoca queda da sucção dentro do tubo e que após algum tempo as leituras voltam a se estabilizar no patamar anterior. Esse fenômeno será mais bem estudado no Ensaio 4; (b) as leituras no tensiômetro analógico foram cerca de $\mathbf{1} \mathbf{~} \mathbf{P a}$ menores que as leituras estabilizadas no tensímetro, nos Ensaios 1 e 2. Considerando-se as leituras no tensiômetro digital como uma boa aproximação da realidade, as leituras no tensímetro foram pouco maiores, ou cerca de $3 \%$; e (c) as leituras nos instrumentos indicaram que a sucção cresceu cerca de $1 \mathrm{kPa}$ por dia nos dois dias de ensaio; isto pode ser explicado pela perda de umidade do sistema para o ambiente, provocando elevação da sucção.

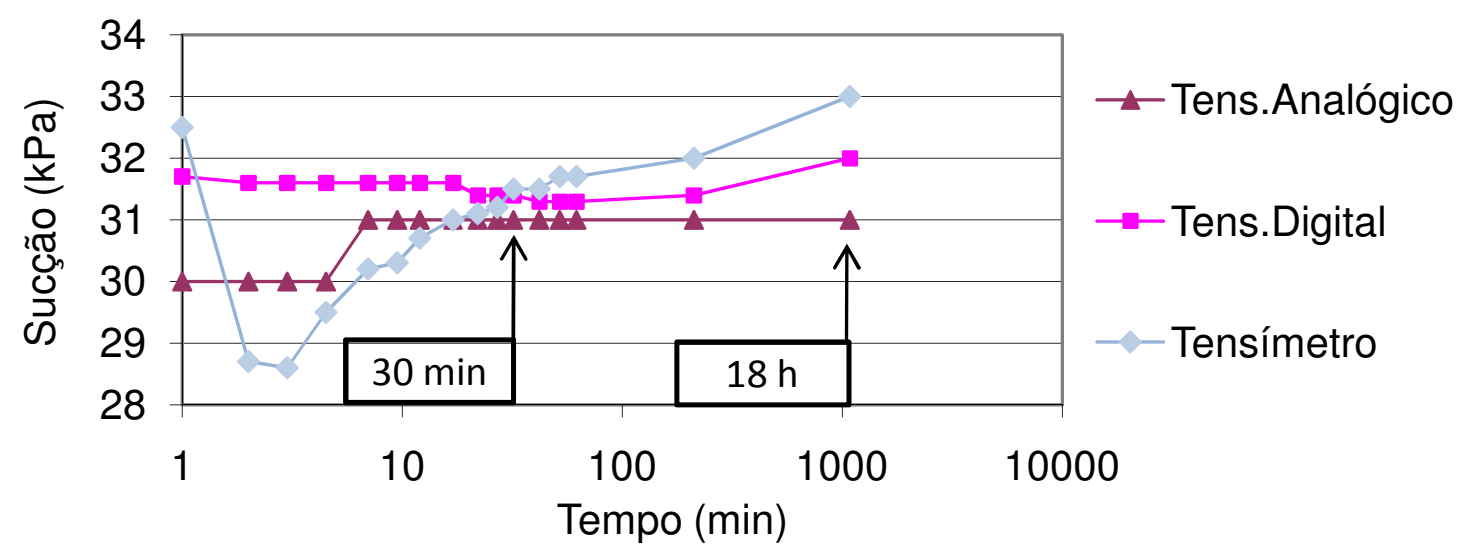

Figura 4.3: Ensaio 2: Retirada e recolocação do tensímetro do tubo tensiométrico

\section{Ensaio 3 - Seqüência de retiradas e inserções do tensímetro, e retirada da tampa do tubo tensiométrico}

Este ensaio foi realizado no dia seguinte ao dia do Ensaio 2 e consistiu na retirada do tensímetro do tubo tensiométrico (ponto A da Figura 4.4) e na sua recolocação uma hora após a sua retirada (ponto B da Figura 4.4). Verificou-se que a leitura havia caído 2,8 $\mathrm{kPa}$, de 33,0 kPa para 30,2 kPa. A seguir foi feita uma seqüência de retiradas e inserções do tensímetro no tubo tensiométrico (ponto $B$ ao ponto $C$ da 
Figura 4.4) com tempo de espera com o tensímetro cravado decrescente de 20 minutos até 1 minuto, e intervalo de tempo entre a retirada e a recolocação de 5 minutos.

Verificou-se que as leituras foram caindo sucessivamente, conforme esperado, pois o instrumento não dispunha de tempo para se estabilizar. As reduções nas leituras entre uma retirada e a inserção seguinte foram caindo de $2,3 \mathrm{kPa}$ até $0,5 \mathrm{kPa}$.

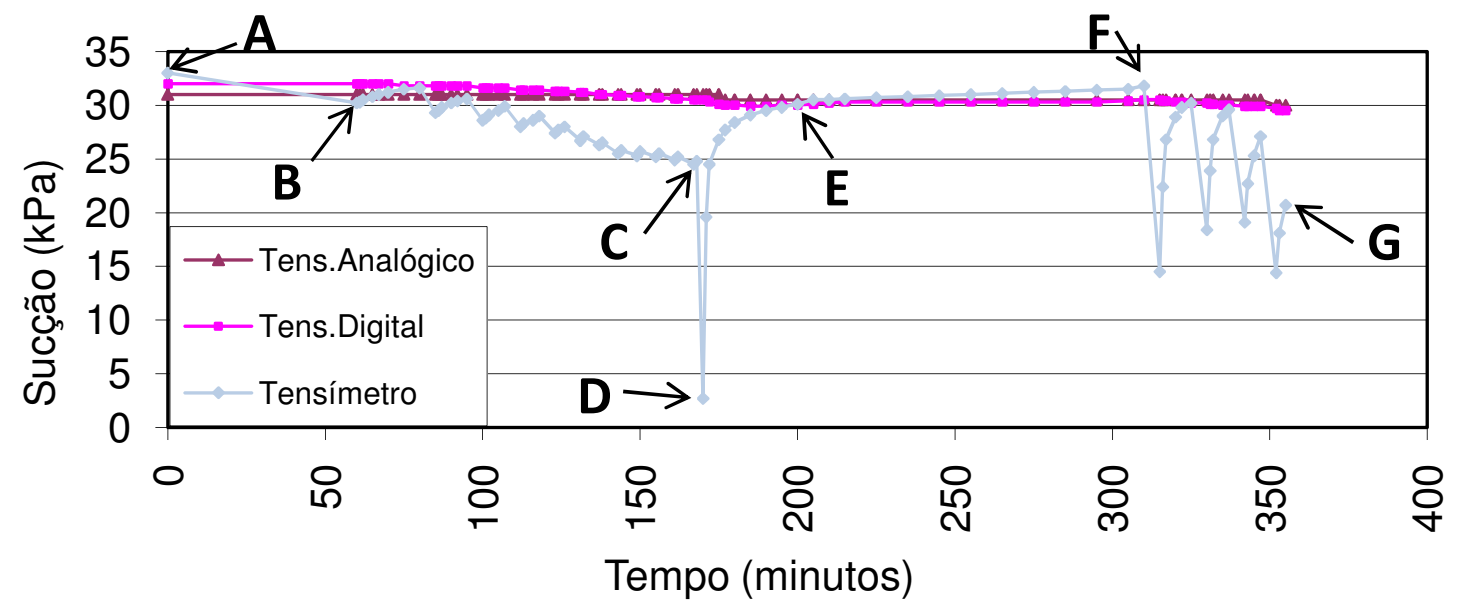

Figura 4.4: Ensaio 3: Seqüência de retiradas e inserções do tensímetro, e retirada da tampa do tubo tensiométrico

Verificou-se também que as leituras no tensiômetro digital caíram de 32,0 kPa para $30,5 \mathrm{kPa}$ no período em que foi feita a seqüência de retiradas e inserções do tensímetro. Isto pode ser explicado pela queda no nível de água do tubo tensiométrico e pela liberação de água do tubo tensiométrico para o solo durante o processo de busca de equilíbrio com o solo, reduzindo a sucção. Neste período o tensiômetro analógico manteve leitura constante de $31,0 \mathrm{kPa}$, sendo incapaz de registrar pequenas alterações de sucção.

A seguir o tensímetro foi retirado e a tampa de silicone do tubo tensiométrico foi removida para preenchimento com água (ponto $C$ da Figura 4.4), com volume adicionado de cerca de $6 \mathrm{~cm}^{3}$. Dois minutos depois a tampa foi recolocada e o tensímetro inserido. A leitura caiu para $2,7 \mathrm{kPa}$ (ponto D da Figura 4.4) e levou 30 
minutos para alcançar a mesma leitura do tensiômetro digital, $30 \mathrm{kPa}$ (ponto $\mathrm{E}$ da Figura 4.4). A estabilização do tensímetro se deu em $31,8 \mathrm{kPa}$ (ponto $\mathrm{F}$ da Figura 4.4) 2,5 horas após a inserção do tensímetro no tubo tensiométrico. Com leitura cerca de $1 \mathrm{kPa}$ maior que a leitura no tensiômetro digital, conforme verificado anteriormente.

Nova seqüência de retiradas e inserções do tensímetro no tubo tensiométrico foi feita (ponto $F$ ao ponto $G$ da Figura 4.4) seguindo os mesmos intervalos de tempo utilizados anteriormente: (a) 5 minutos entre a retirada e a recolocação do tensímetro; e (b) 10 minutos com o tensímetro cravado decrescendo até 5 minutos.

Verificou-se que as quedas foram maiores que as verificadas anteriormente, variando entre $17,3 \mathrm{kPa}$ e $10,5 \mathrm{kPa}$. Acredita-se que as quedas maiores estejam relacionadas com a retirada da rolha de silicone feita antes desta etapa.

Conclui-se que a retirada e recolocação da tampa do tubo tensiométrico provoca elevação da pressão interna do tubo e que se deve esperar cerca de 3 horas para que a pressão retorne à sucção de equilíbrio, nas condições deste ensaio e para o solo residual siltoso ensaiado. Este resultado é útil para orientar intervalos de tempo entre leituras em um mesmo tubo feitas durante ensaios em campo ou em laboratório utilizando-se o tensímetro em solo similar ao ensaiado.

\section{Ensaio 4 - Identificação do momento em que há perda de pressão no tubo tensiométrico}

Este ensaio foi realizado com o objetivo de se identificar em que momento ocorre perda de pressão no tubo tensiométrico durante a utilização do tensímetro.

Iniciou-se o ensaio no dia seguinte ao do ensaio 3 e com a retirada do tensímetro do tubo tensiométrico e com sua recolocação (punção) 30 minutos após a retirada. 0 resultado desse ensaio está mostrado na Figura 4.5. Verificou-se que a leitura havia caído $7,2 \mathrm{kPa}$, de $31,9 \mathrm{kPa}$ para $24,7 \mathrm{kPa}$ (ponto A da Figura 4.5). A seguir o tensímetro foi deixado inserido durante 30 minutos, período em que a leitura cresceu 
para 29,1 kPa, próximo da leitura do tensiômetro digital, 29,2 kPa (ponto B da Figura 4.5).

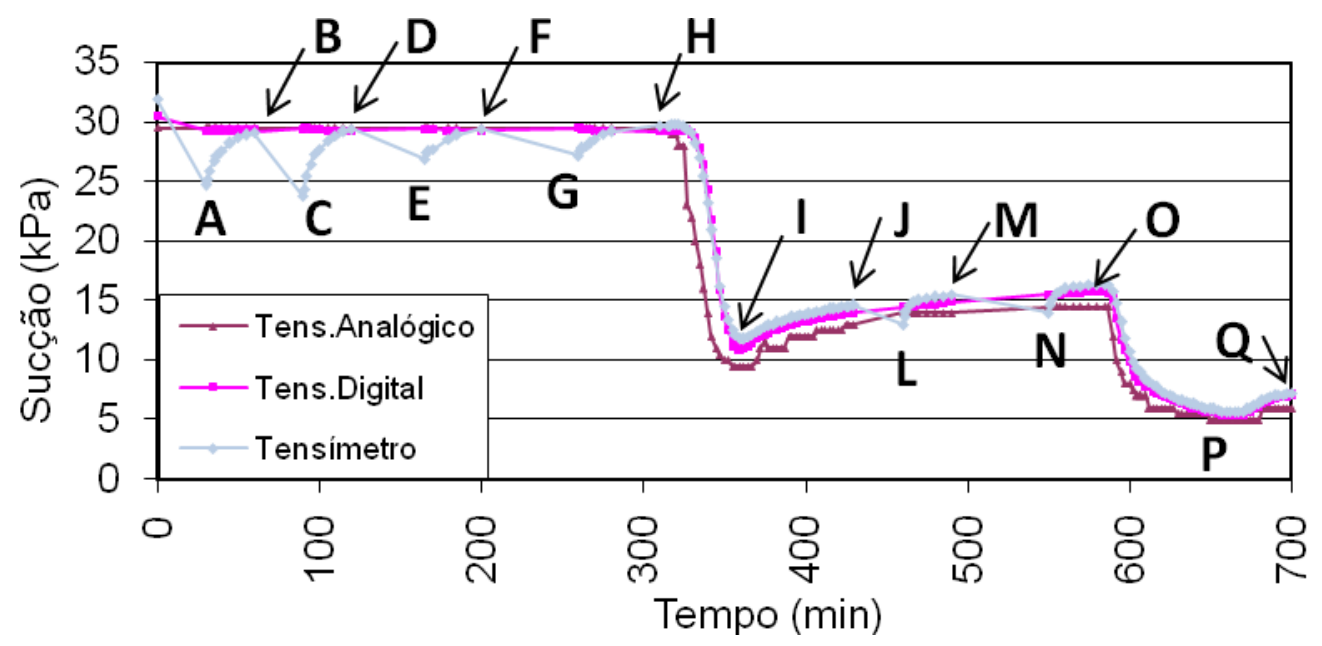

Figura 4.5: Ensaio 4: Seqüência de retiradas e inserções do tensímetro (4 vezes), e de infiltrações de água pelo topo do cilindro de Proctor (2 vezes)

Nova retirada e recolocação do tensímetro, com intervalo de tempo de 30 minutos indicou menor queda na leitura, de $5,3 \mathbf{~ k P a}$, caindo de 29,1 kPa para 23,8 kPa (ponto $C$ da Figura 4.5). Outra seqüência de retirada (ponto $D$ da Figura 4.5) e recolocação (ponto E da Figura 4.5), com intervalo de tempo de 45 minutos, indicou queda ainda menor, de 2,5 Kpa, de 29,4 kPa para 26,9 kPa. E uma quarta e última seqüência de retirada (ponto F da Figura 4.5) e recolocação (ponto G da Figura 4.5), com intervalo de uma hora indicou a menor queda registrada no ensaio, de $\mathbf{2 , 2} \mathbf{k P a}$, caindo de 29,4 para 27,2 kPa.

Supondo-se que as quedas de pressão ocorressem somente no momento da inserção da agulha na tampa do tubo tensiométrico, as quedas seriam constantes, não importando quanto tempo o tensímetro ficasse fora do tubo. Não foi o que ocorreu no ensaio: quanto mais tempo o tensímetro ficou fora do tubo, menores foram as quedas nas leituras registradas logo após a inserção da agulha. Pode-se inferir, portanto, que há perda de sucção no momento da retirada da agulha da tampa de silicone, e que há recuperação de sucção durante o período em que o 
tensímetro fica fora. Tudo indica que no instante da cravação também há perda de sucção, pois se dobrando o tempo de espera de 30 minutos para uma hora, a queda de pressão foi praticamente a mesma, de $2,5 \mathrm{kPa}$, provavelmente correspondente à perda na cravação para as condições do ensaio.

$\mathrm{Na}$ etapa seguinte deste ensaio esperou-se a leitura se estabilizar no mesmo valor do tensiômetro digital, $30 \mathrm{kPa}$ (ponto $\mathrm{H}$ da Figura 4.5), e a seguir foram colocados $271 \mathrm{~cm}^{3}$ de água sobre a superfície superior do cilindro de Proctor. O volume de água foi calculado com o auxílio da curva de retenção, com o objetivo de se reduzir a sucção de 30 para cerca de $15 \mathrm{kPa}$.

Acompanhou-se o efeito desta infiltração na leitura dos tensiômetros. Quinze minutos após o início da colocação de água as leituras de sucção dos instrumentos começaram a registrar queda, e cinqüenta minutos após o início da colocação de água as leituras apresentaram os menores valores de sucção, $10,7 \mathbf{~ k P a}$ (ponto I da Figura 4.5).

Duas horas depois da colocação de água a sucção se aproximou de $10 \mathrm{kPa}$ (ponto $\mathrm{J}$ da Figura 4.5) e retirou-se o tensímetro do tubo tensiométrico. Trinta minutos depois o tensímetro foi reinserido (ponto $L$ da Figura 4.5) e registrou $13,0 \mathrm{kPa}$, com queda de $2,0 \mathrm{kPa}$. Outra seqüência de retirada (ponto $M$ da Figura 4.5 ) e recolocação (ponto $\mathrm{N}$ da Figura 4.5), com intervalo de tempo de 60 minutos, indicou queda menor, de 1,5 Kpa, de 15,5 kPa para 14,0 kPa. Novamente verificou-se uma perda de pressão residual que provavelmente ocorre no momento da inserção da agulha do tensímetro.

Aguardou-se as leituras se estabilizarem em cerca de $16 \mathrm{kPa}$, e então foram colocados mais $285 \mathrm{~cm}^{3}$ de água no cilindro (ponto $O$ da Figura 4.5), com o objetivo de reduzir a suç̧ão a cerca de $5 \mathrm{kPa}$. Sete minutos depois as leituras passaram a registrar queda de sucção. Uma hora e doze minutos depois do início de colocação de água as leituras atingiram os menores valores de sucção (ponto P da Figura 4.5), $\mathbf{5 , 4} \mathbf{~ k P a}$, na média dos instrumentos. Uma hora e doze minutos depois da menor 
leitura, a sucção se estabilizou em 7,2 kPa, na média dos instrumentos (ponto Q da Figura 4.5).

$\mathrm{Na}$ primeira colocação de água todo o líquido se infiltrou em trinta minutos, correspondendo a uma taxa de infiltração de $8,5 \cdot 10^{-4} \mathrm{~cm} / \mathrm{s}$. Na segunda colocação de água todo o líquido se infiltrou em uma hora e dezessete minutos, correspondendo a uma taxa de infiltração menor, de $3,5 \cdot 10^{-4} \mathrm{~cm} / \mathrm{s}$, provavelmente refletindo o menor gradiente de potencial de pressão, como conseqüência da realização do primeiro ensaio.

\subsubsection{Em aterro argiloso}

Foram compactados $8.800 \mathrm{~g}$ de aterro argiloso em cilindro de Proctor com volume de $3.934 \mathrm{~cm}^{3}$ resultando em peso específico de $22,4 \mathrm{kN} / \mathrm{m}^{3}$, e obteve-se valor pouco maior que o peso específico natural do material em campo, 20,5 kN/m ${ }^{3}$. O material foi compactado com 20,4 \% de umidade, próximo da umidade natural, 20,6 \%. A compactação foi feita em oito camadas com aplicação de 35 golpes de soquete de $2,5 \mathrm{~kg}$ em cada camada.

Os furos para instalação dos tensiômetros, e a metodologia de instalação foram feitos da mesma maneira que no ensaio realizado com o solo residual. Depois da instalação dos instrumentos foram realizados dois ensaios descritos abaixo.

\section{Ensaio 1 - Homogeneização da umidade da pasta com o material compactado}

Cerca de 20 minutos após a instalação dos instrumentos as leituras dos tensiômetros passaram a ser registradas, e são apresentadas na Figura 4.6.

Os três tensiômetros levaram 44 horas para ter suas leituras estabilizadas. Foi o tempo requerido para que a umidade da pasta usada na instalação dos instrumentos se equilibrasse com o solo compactado, mais seco. Os três tensiômetros chegaram a leituras próximas, em torno de $20 \mathrm{kPa}$. 
O tempo de estabilização das leituras neste ensaio em argila compactada foi maior que no ensaio com silte compactado, sendo 44 horas neste ensaio e 45 minutos (média dos instrumentos) para o ensaio com solo siltoso. Esta diferença pode ser explicada pela diferença entre as permeabilidades dos materiais, significativamente maior a do silte do que a da argila.

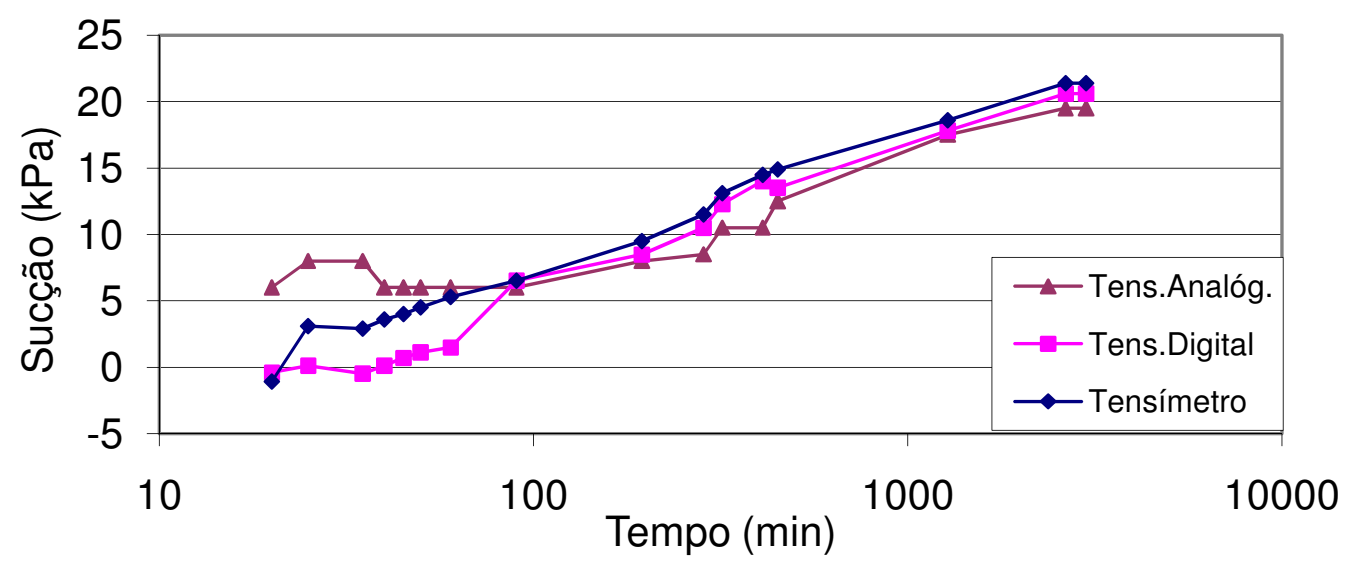

Figura 4.6: Ensaio 1: Homogeneização da umidade da pasta com o a argila compactada

\section{Ensaio 2 - Retirada e recolocação do tensímetro no tubo tensiométrico}

Este ensaio foi realizado da mesma forma que o ensaio realizado com o solo residual exceto o tempo de espera para fazer o puncionamento, que passou de um minuto no ensaio com o solo residual para 30 minutos neste ensaio com o aterro argiloso.

Os resultados do ensaio são apresentados na Figura 4.7, onde se verifica que houve queda de 12,2 $\mathbf{k P a}$, de 21,5 $\mathrm{kPa}$ para 9,3 $\mathrm{kPa}$, logo após a inserção da agulha, maior que no solo residual que apresentou queda de $4 \mathrm{kPa}$.

O tempo para que o tensímetro voltasse a apresentar leitura igual à do tensiômetro digital, 19,7kPa, neste ensaio com argila compactada (210 minutos) foi 8 vezes maior que no ensaio com silte compactado (30 minutos). Essa diferença pode ser explicada pela perda de pressão que ocorre durante a retirada da agulha, que precisa ser reequilibrada pela transferência de água do tubo tensiométrico para o 
solo. Devido à menor permeabilidade do solo argiloso, o tempo para que ocorra o fluxo de água nesse solo é maior que no silte.

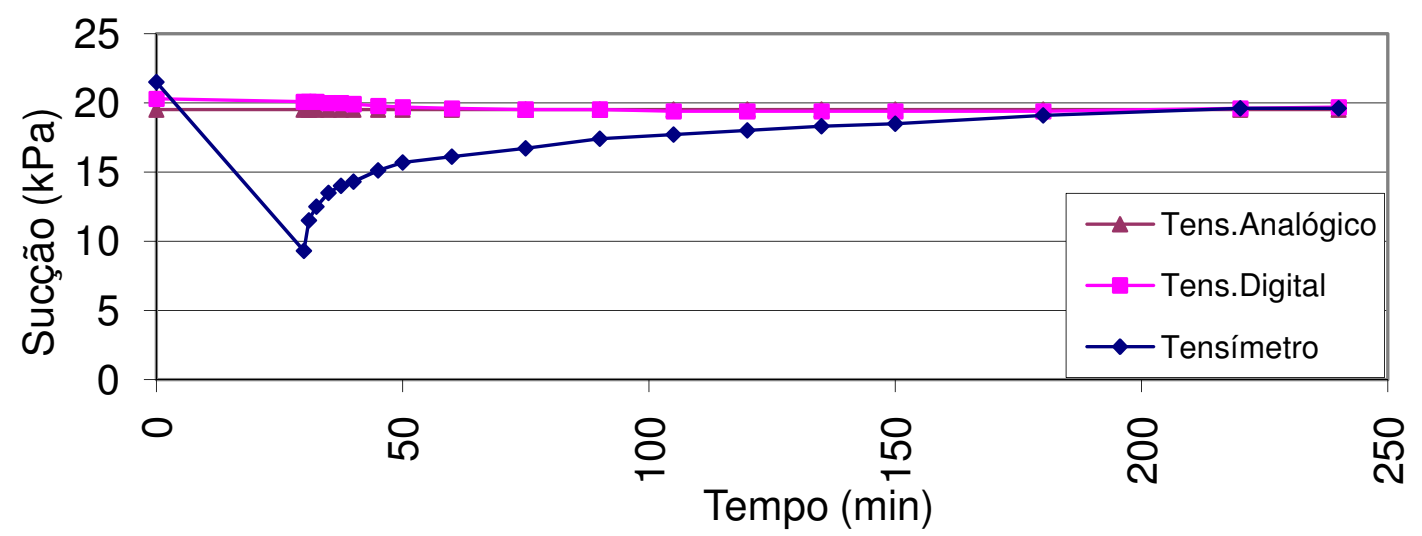

Figura 4.7: Ensaio 2: Retirada e Recolocação do Tensímetro do Tubo Tensiométrico

\subsubsection{Ensaios com tensímetro em campo}

\subsubsection{Fabricante 1}

Ao se iniciarem as leituras, em três de janeiro, verificou-se que as leituras no tensímetro, adquirido junto ao Fabricante 1, ver Figuras 3.16 e 3.17, levavam algumas dezenas de minutos para se estabilizarem e que variavam de um tubo tensiométrico para outro. Decidiu-se então fazer-se um estudo do tempo de estabilização para definir-se um tempo único de leitura em todos os tubos tensiométricos. Entre os dias 19 e 20 de janeiro as leituras foram feitas até que se estabilizassem, ou no máximo duas horas de duração.

A Figura 4.8 apresenta as variações das leituras de poro-pressão de água com o tempo de estabilização das leituras, com tensímetro puncionado no tubo tensiométrico. Nos gráfico (a), (b) e (c) desta figura são apresentados resultados de tensiômetros instalados a 0,5 m, 1,5 m e 3,0 m de profundidade, respectivamente. Verificou-se não haver uma correlação entre o tempo de estabilização e a profundidade de instalação do tubo tensiométrico nem com o nível de poro-pressão de água. Verificou-se sim um comportamento diferenciado entre os tempos de estabilização dos tensiômetros instalados no solo argiloso com os instalados no solo siltoso, conforme apresentado abaixo. 


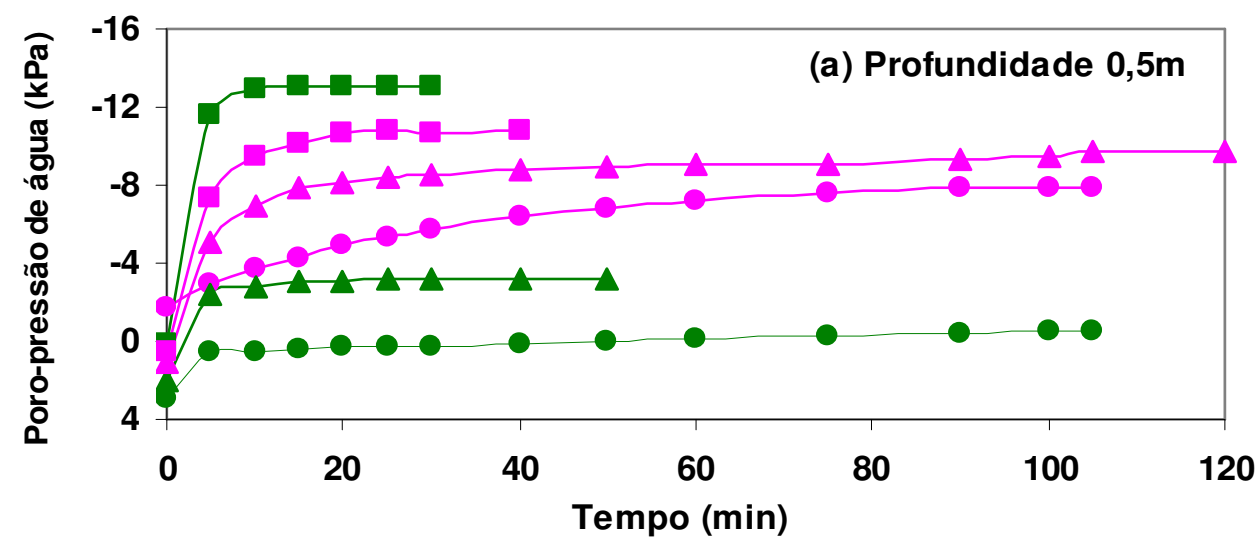

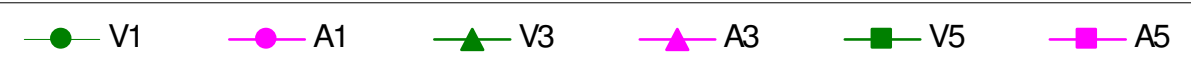
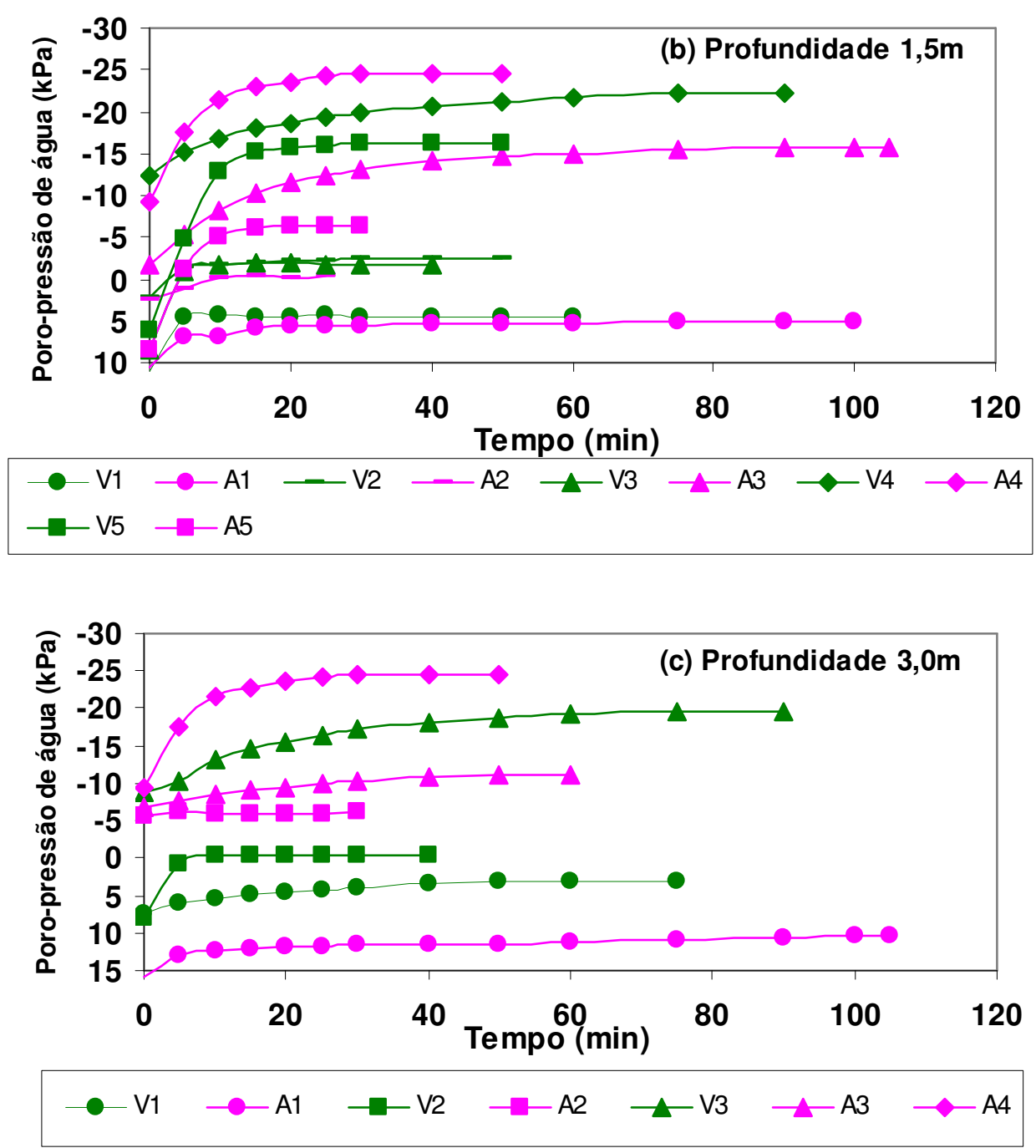

Figura 4.8: Estabilização das leituras no tensímetro, fornecido pelo fabricante 1 
O procedimento adotado foi: após o puncionamento do tensímetro no tubo tensiométrico foram feitas leituras após 5, 10, 15, 20, 25, 30, 40, 50, 60, 75, 90, 105 e 120 minutos. Os resultados, apresentados na Tabela 4.1, indicaram que as leituras se estabilizaram em média na argila com aproximadamente 50 minutos, e no silte com cerca de 20 minutos, considerando leitura estabilizada valores maiores que 95 $\%$ da leitura final.

Tabela 4.1: Tempo de estabilização das leituras no tensímetro fornecido pelo fabricante 1

\begin{tabular}{|c|c|c|}
\hline \multirow{2}{*}{$\begin{array}{c}\text { Tempo após o } \\
\text { puncionamento }\end{array}$} & \% da leitura de estabilização \\
\cline { 2 - 3 } & Argila & Silte \\
\hline (min) & $(\%)$ & $(\%)$ \\
\hline 5 & 51 & 62 \\
\hline 10 & 63 & 87 \\
\hline 15 & 78 & 94 \\
\hline 20 & 79 & 96 \\
\hline 25 & 85 & 98 \\
\hline 30 & 86 & 98 \\
\hline 40 & 91 & 99 \\
\hline 50 & 97 & 99 \\
\hline
\end{tabular}

\subsubsection{Fabricante 2}

O tensímetro digital fornecido pelo segundo fabricante, ver Figura 4.1, apresentou tempo de estabilização menor que o do primeiro. $O$ projeto desenvolvido em conjunto com o segundo fabricante previu uma câmara interna menor que a do primeiro tensímetro, diminuindo o tempo de resposta. As leituras efetuadas em campo em 9/04/05, início das leituras com o novo instrumento, constatou que as leituras se estabilizavam em média após 15 minutos. Leituras efetuadas após 5 minutos correspondem a $80 \%$ das leituras de 15 minutos; e leituras efetuadas após 10 minutos correspondem a $93 \%$ das leituras de 15 minutos, conforme apresentado na Figura 4.9. Portanto, adotou-se 15 minutos como tempo de leitura para o período final do experimento, 11/04/05 a 23/09/05, após o tensímetro digital fornecido pelo fabricante 1 apresentar defeitos. 


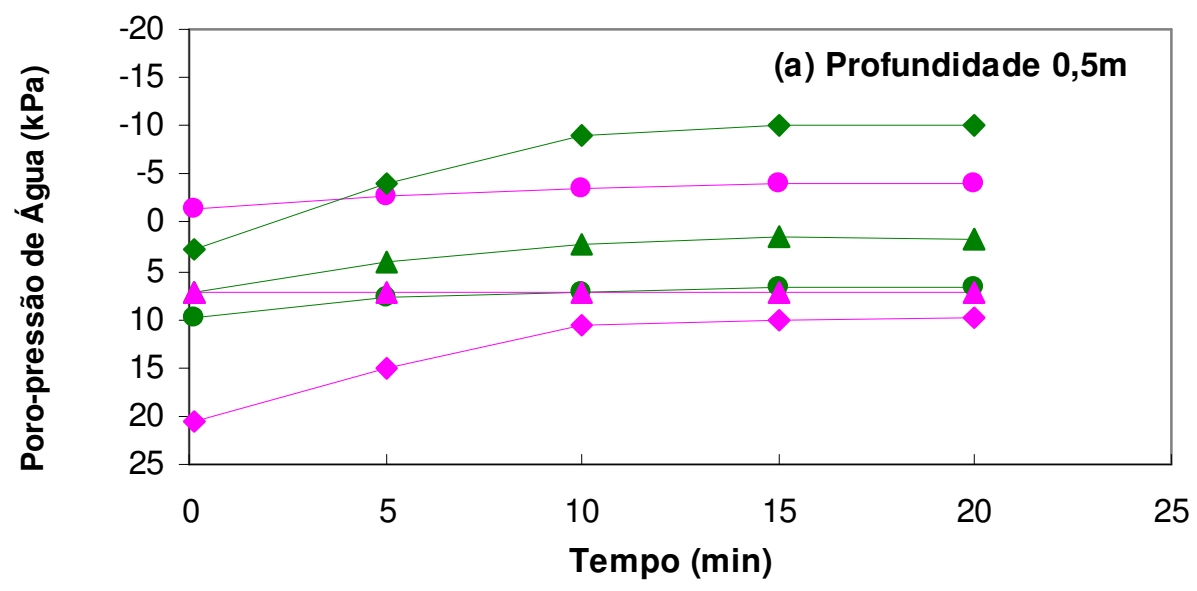

$\bullet \mathrm{V} 1 \multimap \mathrm{A} 1 \multimap \mathrm{V} 3 \multimap \mathrm{A} 3 \rightarrow \mathrm{V} 5 \multimap \mathrm{A} 5$

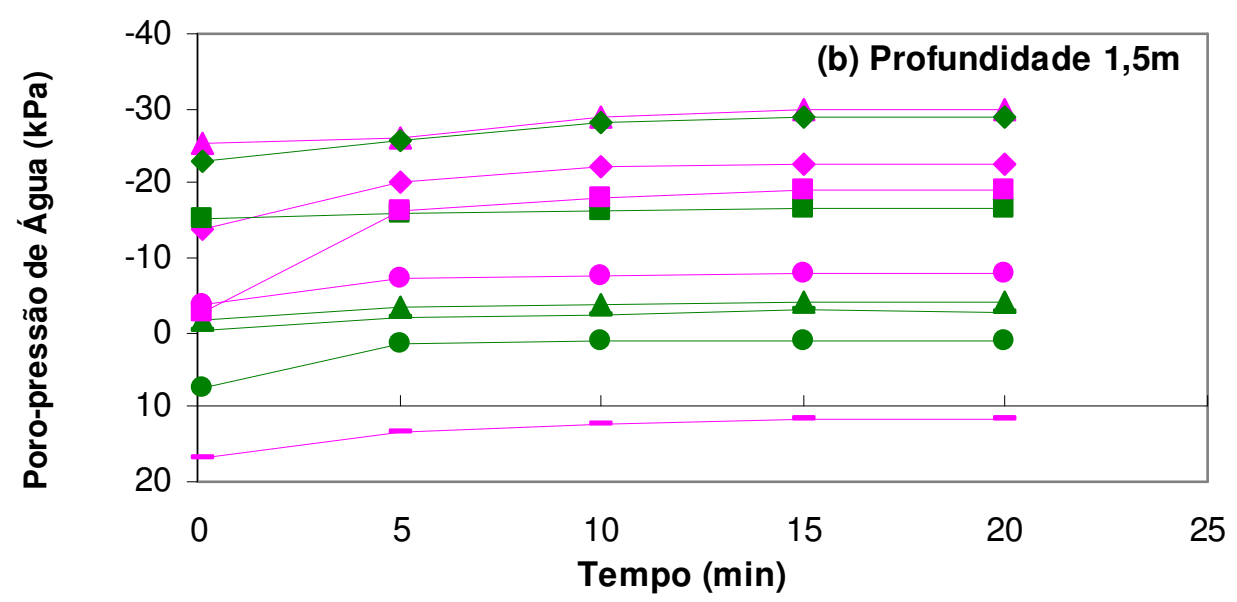

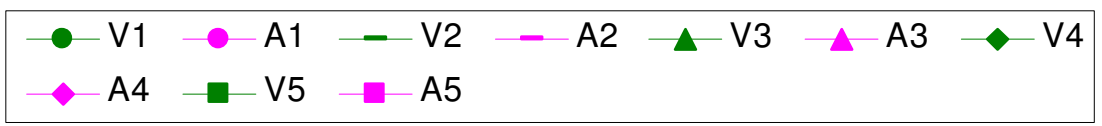

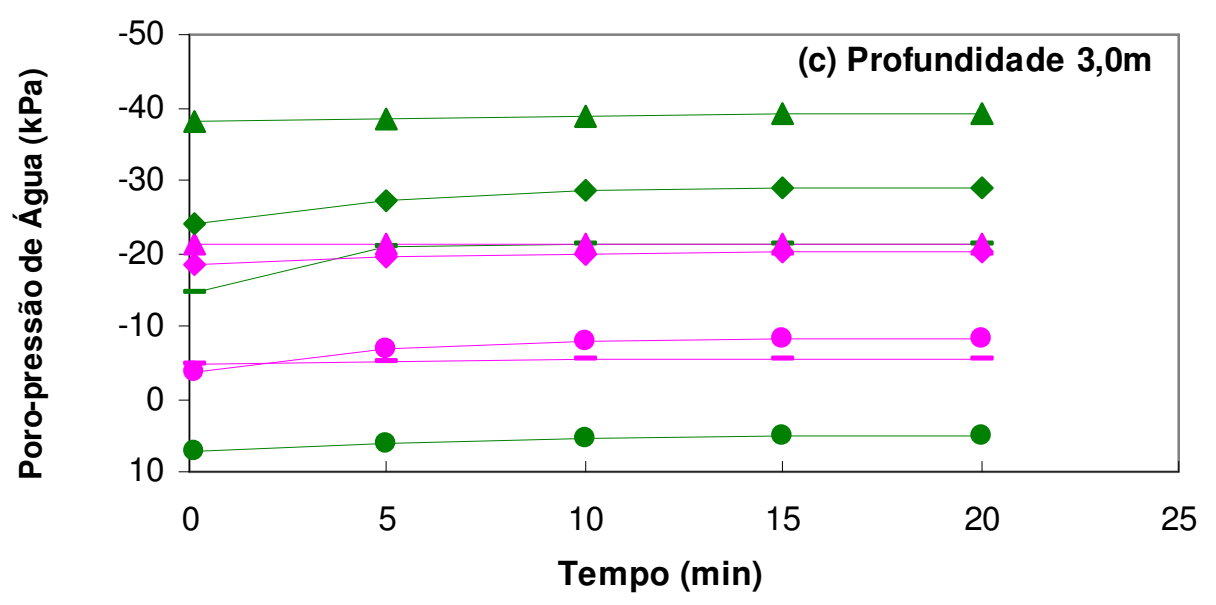

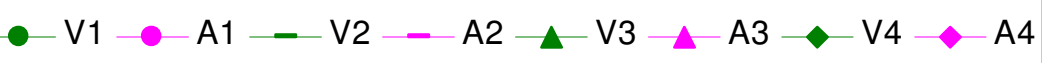

Figura 4.9: Estabilização das leituras no tensímetro, fornecido pelo fabricante 2 
Os resultados indicaram que as leituras se estabilizaram no máximo com 15 minutos, e que as leituras no solo siltoso estabilizaram-se mais rapidamente do que no solo argiloso, conforme ocorreu nos ensaios realizados com o tensímetro fornecido pelo primeiro fabricante.

No ensaio realizado em campo, o procedimento adotado foi: após o puncionamento do tensímetro no tubo tensiométrico foram feitas leituras após 5, 10 e 15 minutos. Os resultados, apresentados na Tabela 4.2, indicaram que as leituras no solo siltoso estabilizaram-se mais rapidamente (10 minutos) do que no solo argiloso (15 minutos), conforme ocorreu nos ensaios realizados com o tensímetro fornecido pelo primeiro fabricante, considerando critério de estabilização valores maiores que $95 \%$ da leitura final.

Tabela 4.2: Tempo de estabilização das leituras no tensímetro fornecido pelo fabricante 2

\begin{tabular}{|c|c|c|}
\hline \multirow{2}{*}{$\begin{array}{c}\text { Tempo após o } \\
\text { puncionamento }\end{array}$} & \% da leitura de estabilização \\
\cline { 2 - 3 } & Argila & Silte \\
\hline (min) & $(\%)$ & $(\%)$ \\
\hline 0,1 & 37 & 63 \\
\hline 5 & 73 & 84 \\
\hline 10 & 88 & $\mathbf{9 7}$ \\
\hline 15 & 100 & 100 \\
\hline
\end{tabular}

O tempo de estabilização do tensímetro fornecido pelo fabricante 2 , utilizado neste ensaio, 15 minutos (argila) e 10 minutos (silte), é menor do que o tempo de estabilização do tensímetro fornecido pelo Fabricante 1, 50 minutos (argila) e 20 minutos (silte). Isso se deve ao fato de que o primeiro instrumento dispõe de câmara interna maior que o segundo. A câmara interna do tensímetro armazena ar na pressão atmosférica. Quando o tensímetro é inserido no tubo tensiométrico essa porção de ar, que está sob pressão atmosférica, deve se estabilizar com a pressão da água que há no interior do tubo tensiométrico. Portanto quanto maior a câmara 
interna do instrumento, maior o tempo necessário para a estabilização da leitura ocorra.

Nesse processo de estabilização de pressões é necessário que ocorra fluxo de água do interior do tubo tensiométrico em direção ao solo, através da pedra porosa localizada na extremidade inferior do tubo tensiométrico. Esse fluxo é tanto mais demorado quanto maior a permeabilidade do solo em contato com a pedra porosa. O que explica o fato registrado acima, de que tubos instalados em argila (que tem menor permeabilidade) apresentarem maior tempo de estabilização do que tubos instalados em solo siltoso (que tem maior permeabilidade).

\subsubsection{Comparação dos ensaios em laboratório com os de campo}

Tempo de estabilização das leituras no tensímetro fornecido pelo segundo fabricante, em campo, comparado com os resultados de laboratório

A diferença entre os resultados obtidos em campo, 15 minutos para o tempo de estabilização na argila e $\mathbf{1 0}$ minutos no silte, medidos com o tensímetro fornecido pelo segundo fabricante, e $\mathbf{2 1 0}$ minutos para a argila e $\mathbf{3 0}$ minutos para o silte nos ensaios em laboratório, utilizando o mesmo instrumento, pode ser explicada pelo tempo transcorrido entre a retirada do tensímetro do tubo tensiométrico e sua recolocação no tubo, que em campo foi de 1 dia, e em laboratório foi de 1 hora.

Conforme visto no Ensaio 4, quanto maior o tempo de espera após a retirada do tensímetro do tubo tensiométrico, maior é a retomada da pressão dentro do tubo. Isso se deve ao fato de que a maior perda de pressão ocorre na retirada da agulha do tensímetro da tampa de silicone do tubo tensiométrico, e não durante sua recolocação. Portanto a diferença de 1 dia para uma hora nos ensaios de campo e de laboratório, respectivamente, provocou diferentes tempos de estabilização no tensímetro fornecido pelo segundo fabricante.

A utilização do tensímetros em monitoramentos de campo deve ser precedida por ensaios, preferencialmente, em campo que definam a ordem de grandeza do tempo 
de leitura necessário para estabilizar a leitura no tensímetro. Essa informação é essencial para se estimar o número de tensímetros a serem utilizados em um monitoramento, e ou o número de pessoas necessárias para operá-los, considerando que esse fator estabelece e influencia os principais custos do monitoramento.

\section{Utilização do tensímetro analógico em campo comparado com sua utilização em laboratório}

As leituras efetuadas com o tensímetro analógico em laboratório apresentaram-se coerentes com as leituras efetuadas em com os demais tipos tensiômetros. As leituras efetuadas em campo com esse instrumento, entre $1^{\circ}$ de março e 8 de abril, não se apresentaram coerentes entre si e com as precipitações registradas durante o período, e portanto não foram incluídas aos resultados do monitoramento a serem apresentados neste trabalho. Pode-se tentar explicar a diferença de comportamento do tensímetro analógico pela manipulação e transporte do instrumento em campo, que pode ter alterado seguidamente a sua calibração, isto é, o ponto de leitura igual a zero do instrumento, o que não ocorreu no laboratório. O tensímetro analógico não foi manipulado e não sofreu impactos durante os ensaios de laboratório.

\subsubsection{Dificuldades encontradas no monitoramento com tensímetro}

O tensímetro digital, fornecido pelo fabricante 1 , inicialmente utilizado no monitoramento apresentou defeito por três vezes e foi necessário substituí-lo por tensímetro analógico que não apresentou resultados coerentes. Posteriormente o tensímetro analógico foi substituído por um tensímetro digital fornecido pelo fabricante 2, que não apresentou defeitos até o final do experimento.

Os tubos tensiométricos de três metros de comprimento apresentaram vazamento de água por rompimento das luvas de emenda dos tubos de PVC. As luvas 
fornecidas pelo fabricante foram torneadas para reduzir a espessura da parede e apresentaram trincas. A solução adotada foi aumentar a espessura das luvas.

\subsection{Ensaios com os solos do campo experimental}

\subsubsection{Ensaios de caracterização}

As amostras coletadas nas sondagens a trado foram submetidas a ensaios de caracterização: granulometria, limite de liquidez, limite de plasticidade e massa específica dos grãos. E com amostras retiradas dos blocos indeformados foram realizados os mesmos ensaios, e foram incluídos ensaios de determinação da umidade natural e massa específica natural.

Os resultados dos ensaios e análises tácteis visuais realizados com as amostras coletadas nas sondagens a trado indicaram a existência de três horizontes bem definidos. Até cerca de três metros de profundidade há aterro compactado de argila areno-siltosa, vermelha e branca; abaixo do aterro há camada de argila siltoarenosa, com detritos vegetais, marrom escuro, com cerca de $20 \mathrm{~cm}$ de espessura; e subjacente a essa camada há solo residual maduro siltoso areno-argiloso, micáceo, marrom avermelhado. O solo residual siltoso apresenta plano de foliação bem definido com direção $\mathrm{N} 45^{\circ} \mathrm{E}$, e mergulho de $45^{\circ}$ para sudeste.

Foram realizados ensaios de granulometria com amostras retiradas dos blocos indeformados e das sondagens a trado ST-01 a ST-03. Em amostras retiradas dos blocos indeformados, de aterro argiloso e de solo residual siltoso, os ensaios de granulometria foram feitos com e sem a utilização de defloculante.

Os resultados dos ensaios com defloculante indicaram argila areno-siltosa para o aterro e silte areno-argiloso para o solo residual, conforme se pode verificar na Figura 4.10. Os resultados dos ensaios sem defloculante indicaram solo arenosiltoso para o aterro e para o solo residual. 


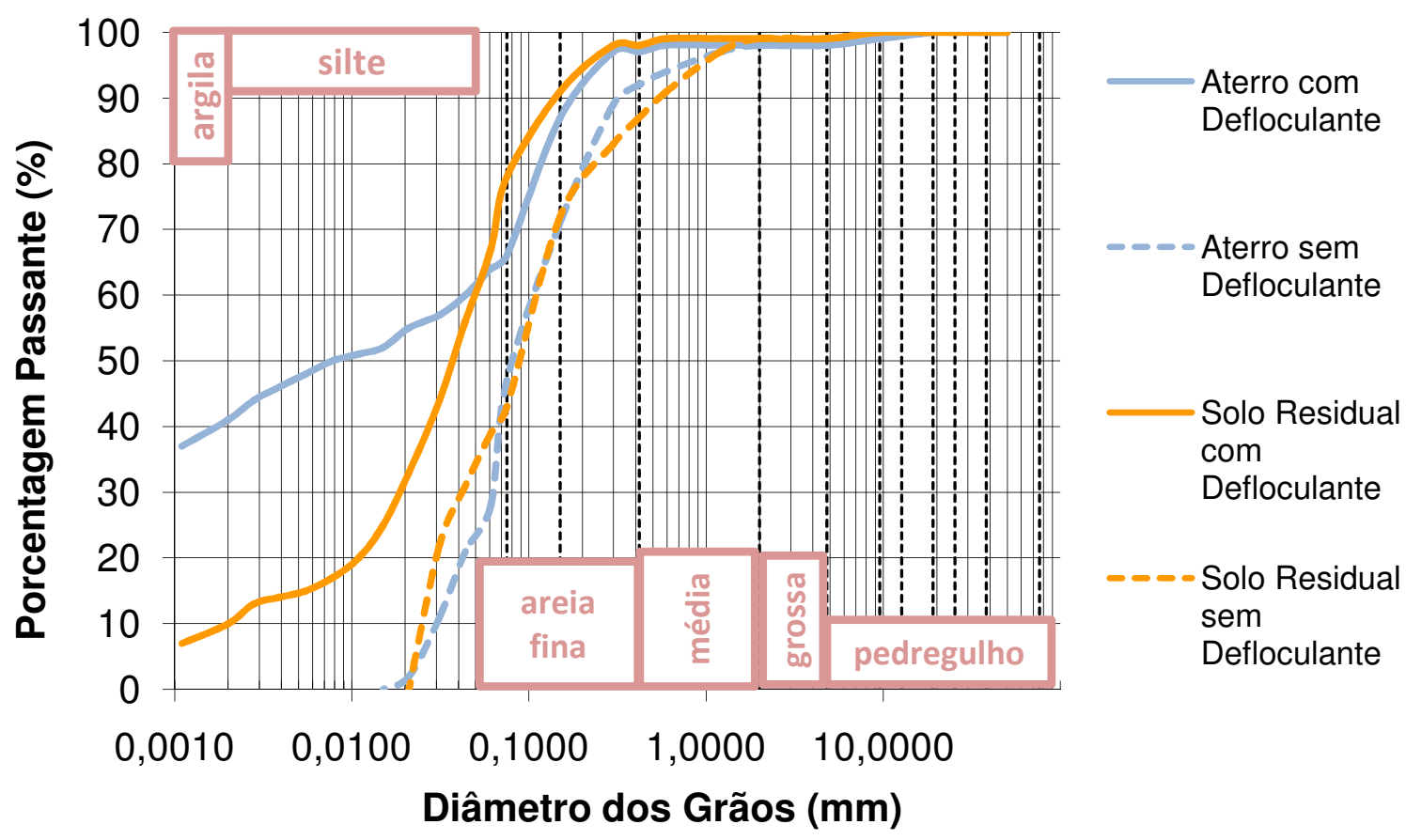

Figura 4.10: Curvas granulométricas de amostras dos blocos indeformados, com e sem defloculante

Os resultados dos ensaios de granulometria realizados com amostras de diversas profundidades das sondagens a trado ST-01 a ST-03 são apresentados nas Figuras 4.11 a 4.13. Os resultados confirmam as granulometrias obtidas nos ensaios com amostras dos blocos indeformados, isto é, argila areno-siltosa para o aterro que ocorre até a profundidade de $3 \mathrm{~m}$ e silte areno-argiloso para o solo residual que ocorre abaixo daquela profundidade.

A 2 m de profundidade na ST-02 ocorre uma alteração na granulometria do material, que passa de argila areno-siltosa para areia argilosa. Foi ensaiada também amostra do solo argiloso com matéria orgânica de contato entre os horizontes principais. A amostra foi retirada da profundidade de 3,1 da ST-01. O resultado do ensaio indicou ser uma argila areno-siltosa. 


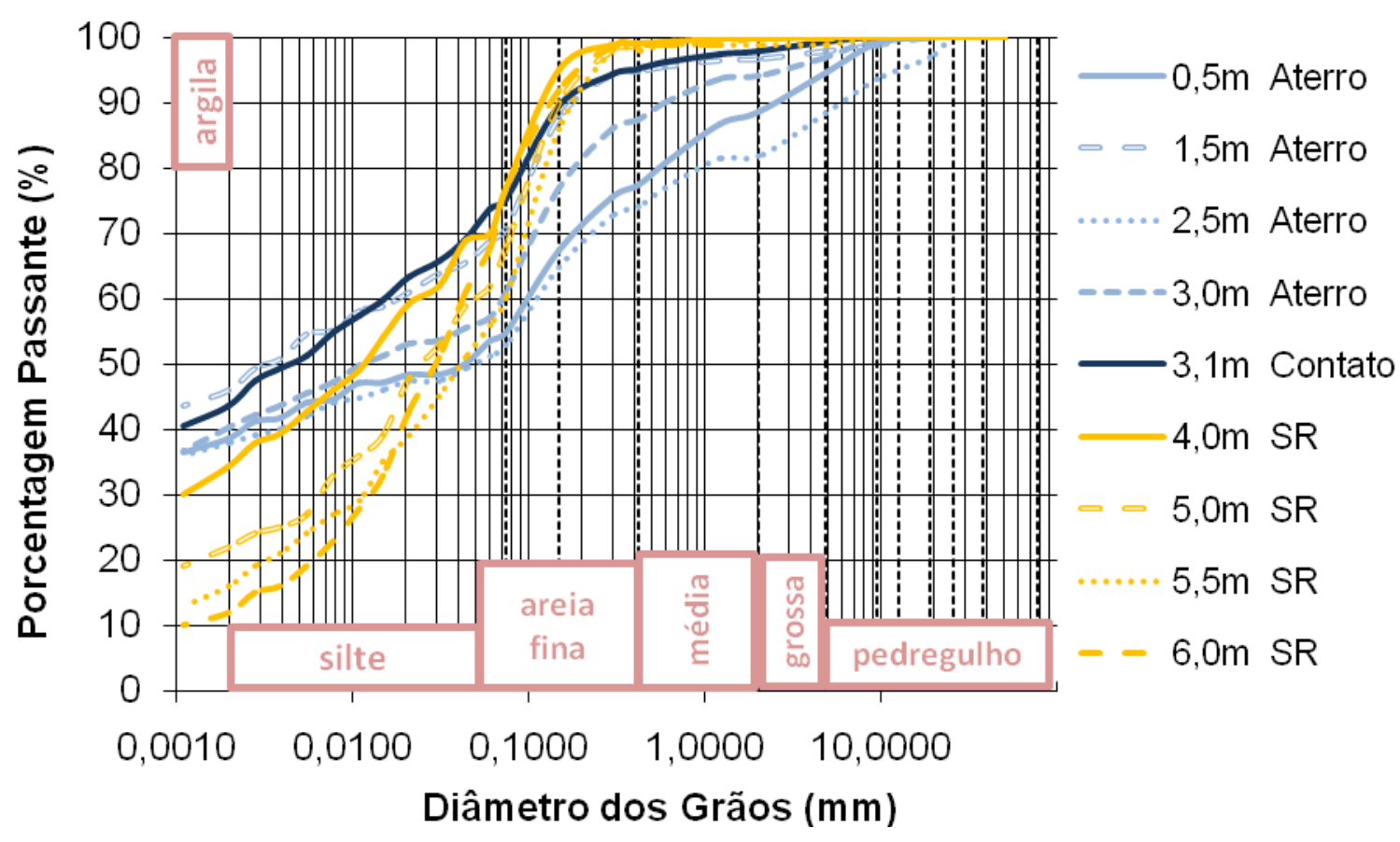

Figura 4.11: Curvas granulométricas de amostras da sondagem a trado 1

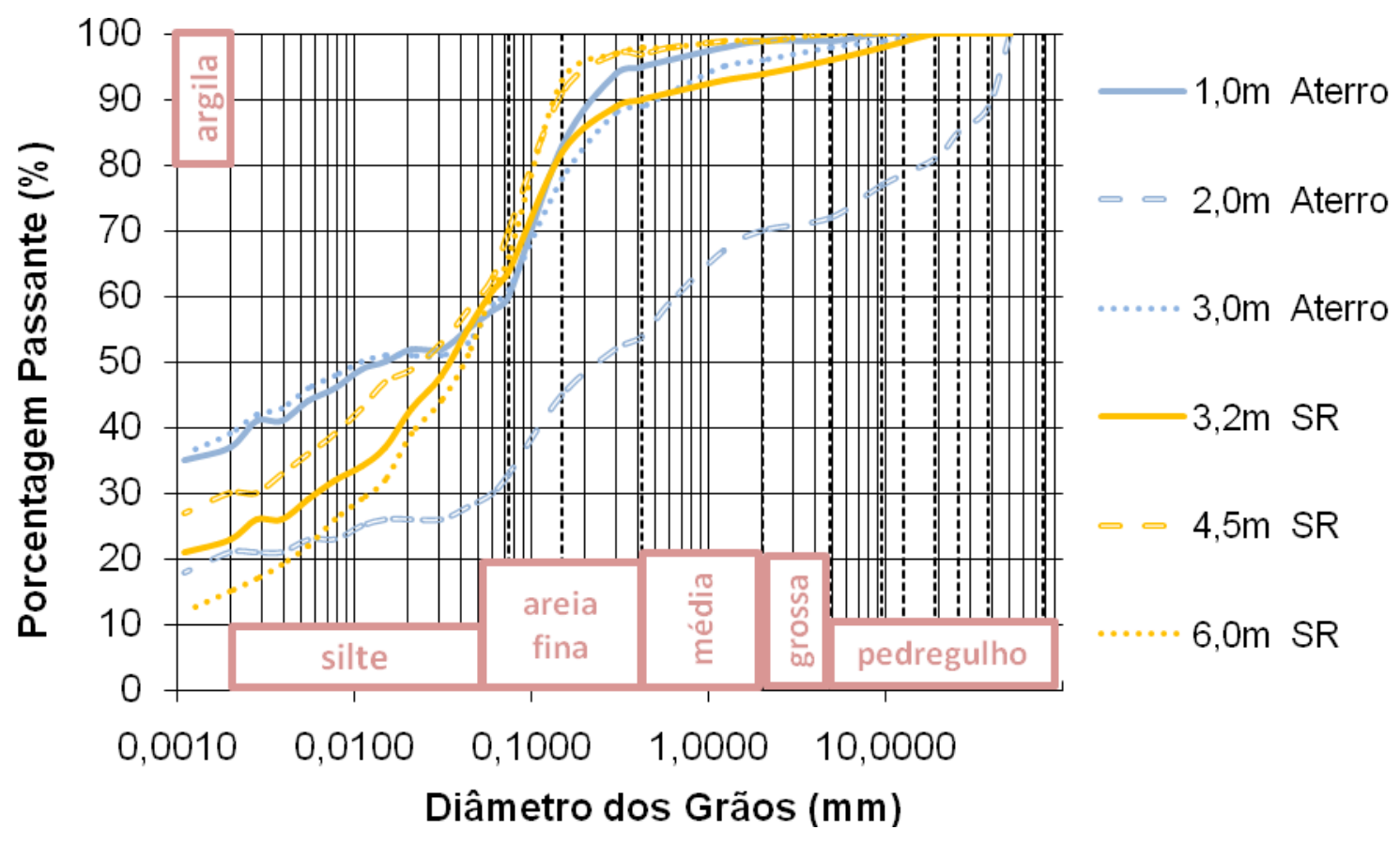

Figura 4.12: Curvas granulométricas de amostras da sondagem a trado 2 


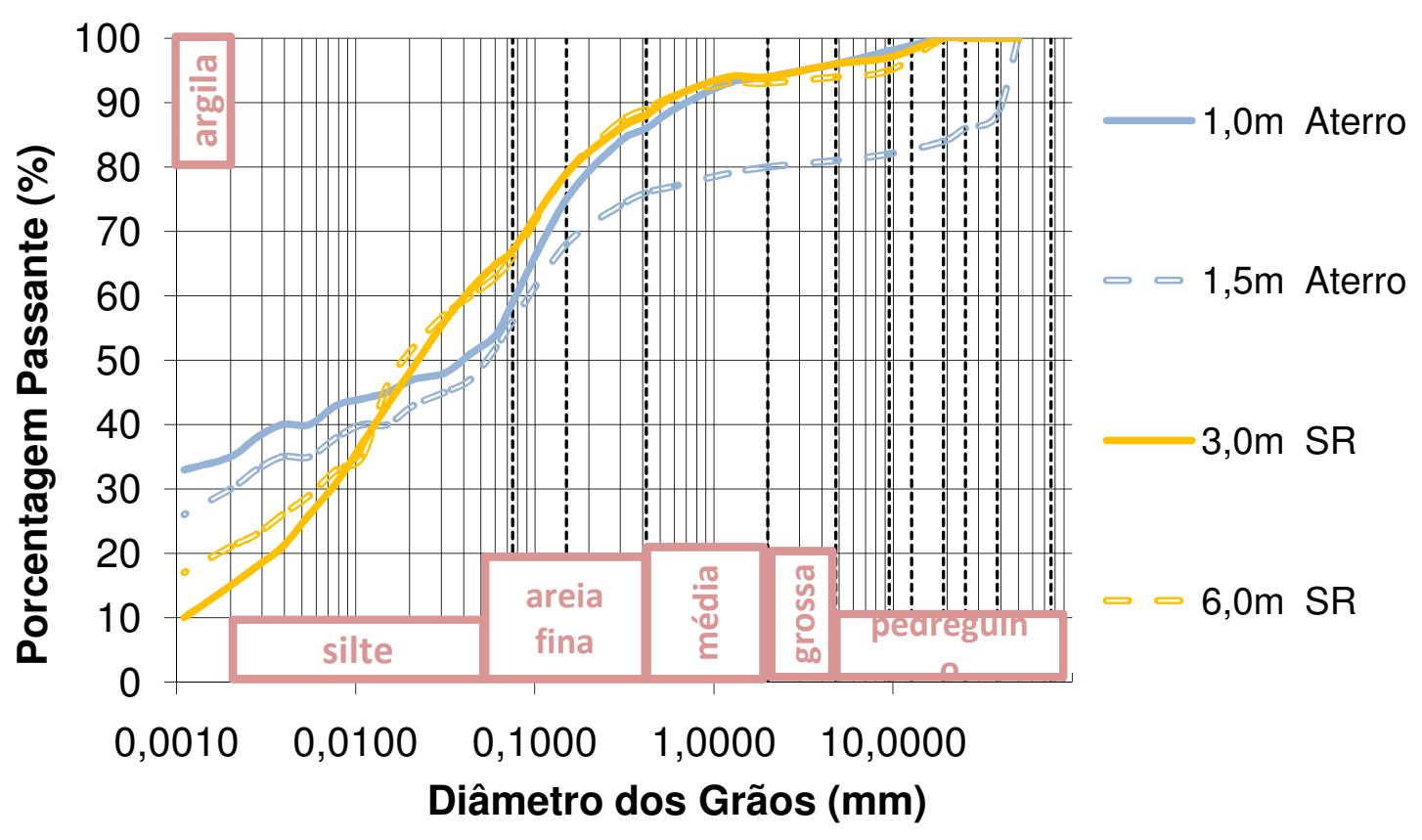

Figura 4.13: Curvas granulométricas de amostras da sondagem a trado 3

Comparando-se as granulometrias das amostras retiradas dos blocos indeformados com a média das granulometrias das amostras retiradas das sondagens a trado verifica-se uma dispersão de resultados que pode ser explicada pela heterogeneidade natural dos solos, conforme mostrado nas Figuras 4.14 e 4.15.

A fração arenosa de ambos os solos, aterro e solo residual, é composta essencialmente por areia fina com pequenas percentagens de areias média e grossa. Há presença de pedregulho em percentagem que varia de 0 a $10 \%$.

No ensaio sem defloculante com o aterro argiloso não se obteve os $40 \%$ de argila que tinha no ensaio com defloculante, que se distribuiu entre areia fina (30\%), silte $(5 \%)$ e areia média (5\%). No ensaio com solo residual sem defloculante também não se obteve fração argila, e parte da fração siltosa (18\%) que tinha no ensaio com defloculante, e que se distribuíram parte na fração areia fina (17\%) e parte na fração areia grossa (11\%). 


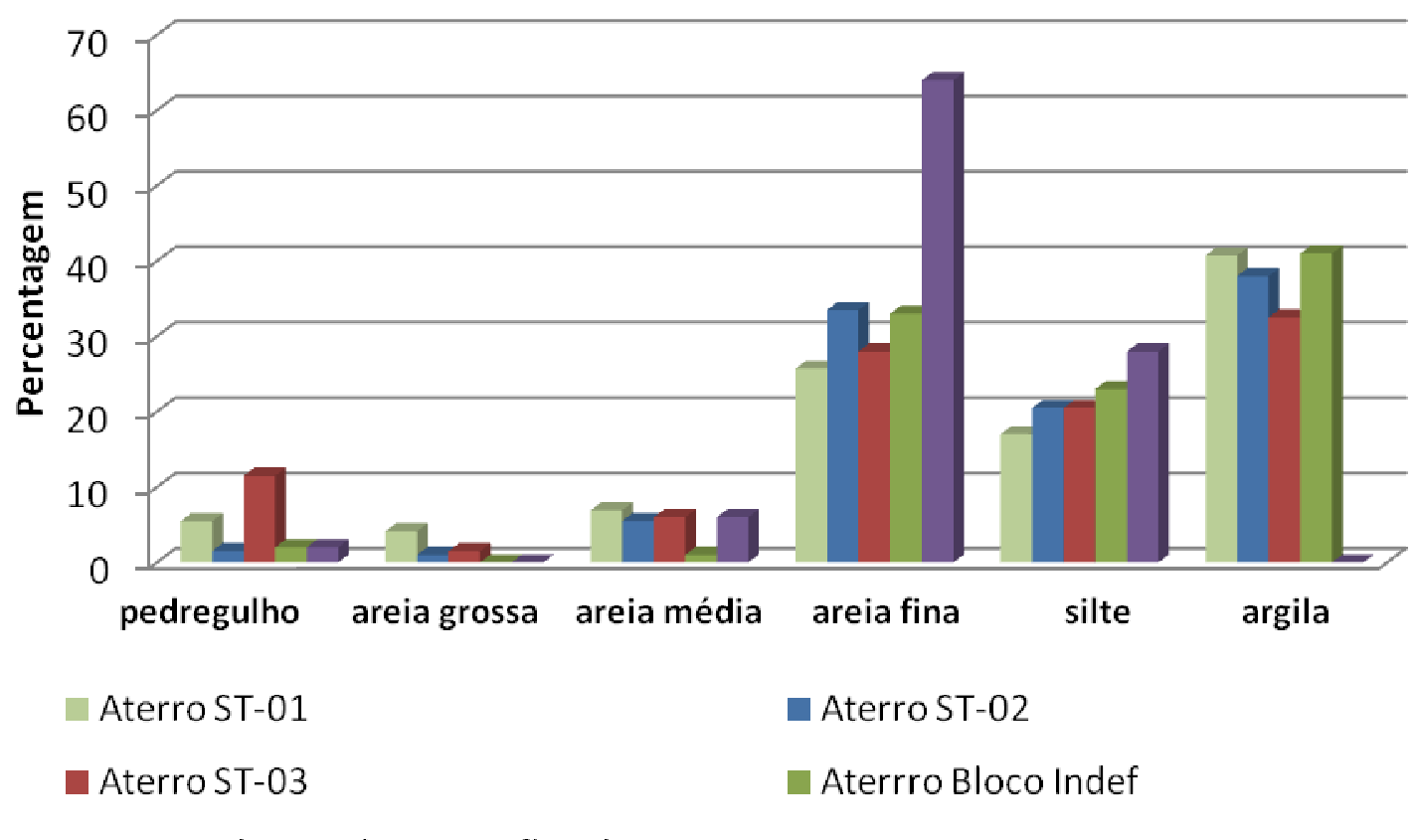

Aterro Bloco Ind. Sem Defloculante

Figura 4.14: Percentagem das frações granulométricas do aterro

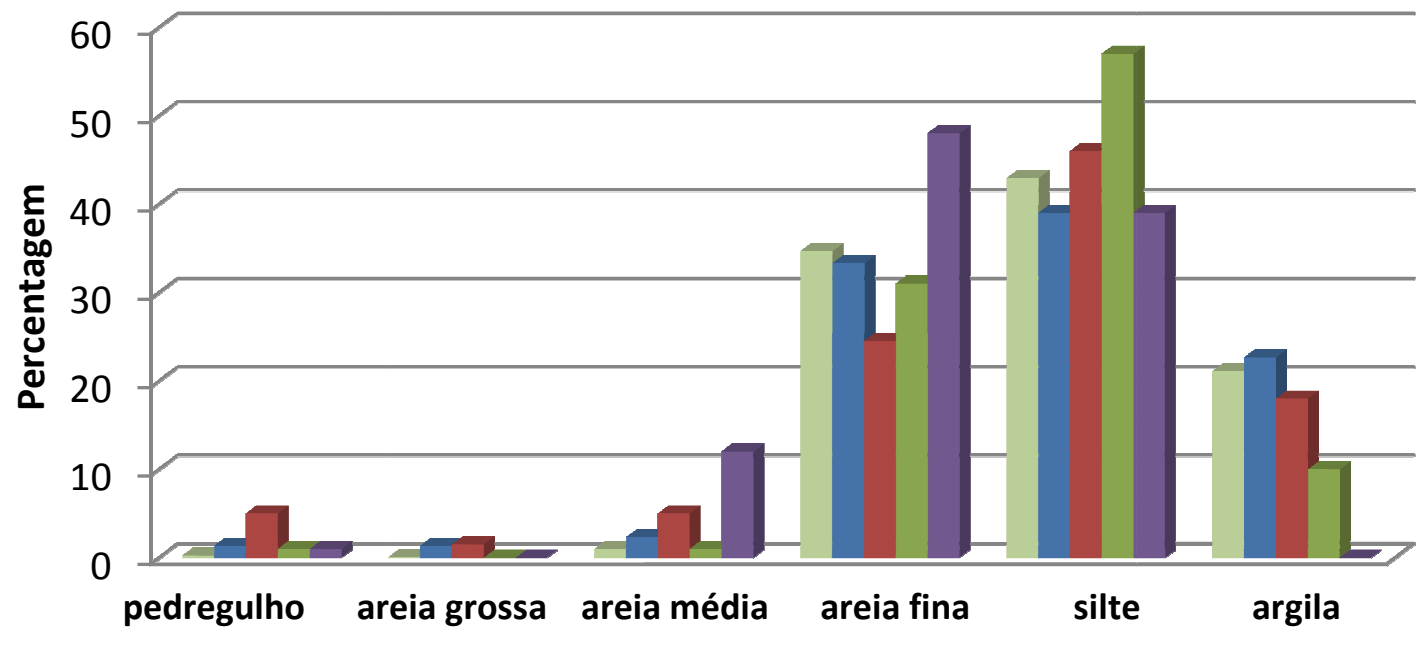

Solo Residual ST-01

- Solo Residual ST-02

- Solo Residual ST-03

Solo Residual Bloco Indef

- Solo Residual Bloco Ind. Sem Defloculante

Figura 4.15: Percentagem das frações granulométricas do solo residual 
Na sondagem a trado ST-1, localizada na crista do talude, a camada de argila com detritos vegetais de contato entre o aterro e o solo residual se dá a cerca de 3,0 m de profundidade, com $10 \mathrm{~cm}$ de espessura, conforme apresentado na Figura 4.16, que indica a variação da granulometria com a profundidade. Na ST-2, que está localizada 2,5 m abaixo da crista do talude, o contato também ocorre a 3,0 m de profundidade, e tem cerca de $20 \mathrm{~cm}$ de espessura; e na ST-3, localizada na metade da altura do talude, o contato localiza-se a 3,0 m de profundidade, e tem cerca de 20 $\mathrm{cm}$ de espessura.

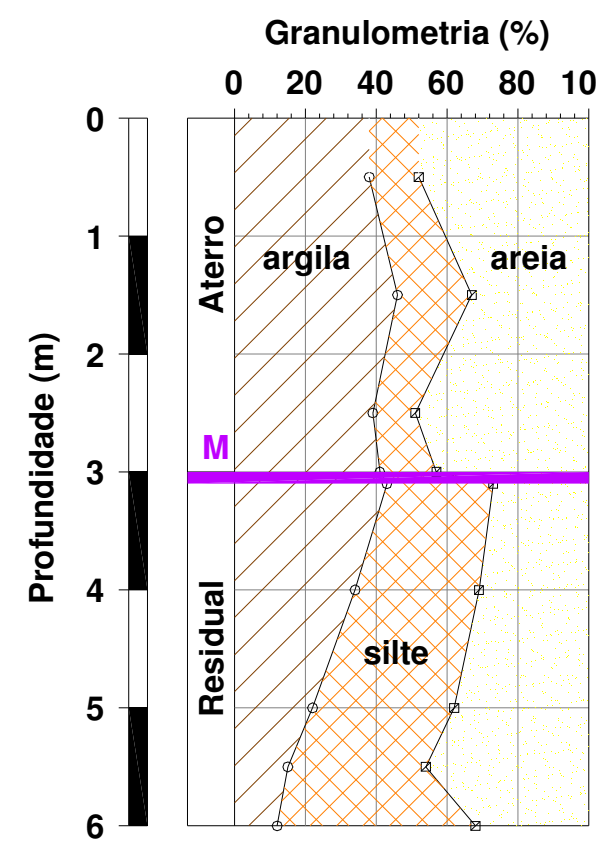

(a) ST-01
Granulometria (\%)

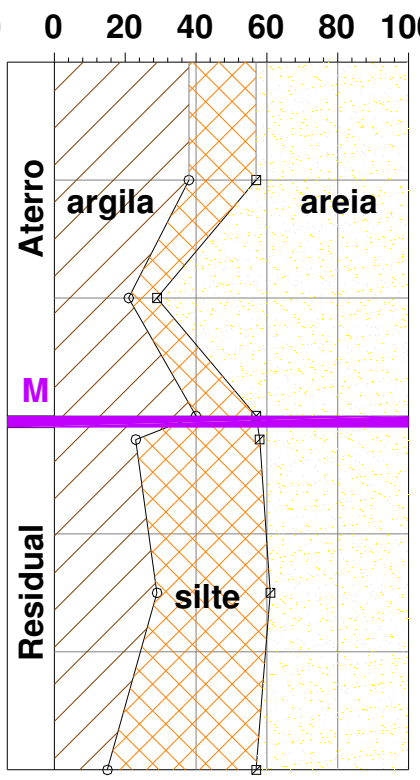

(b) ST-02
Granulometria (\%)

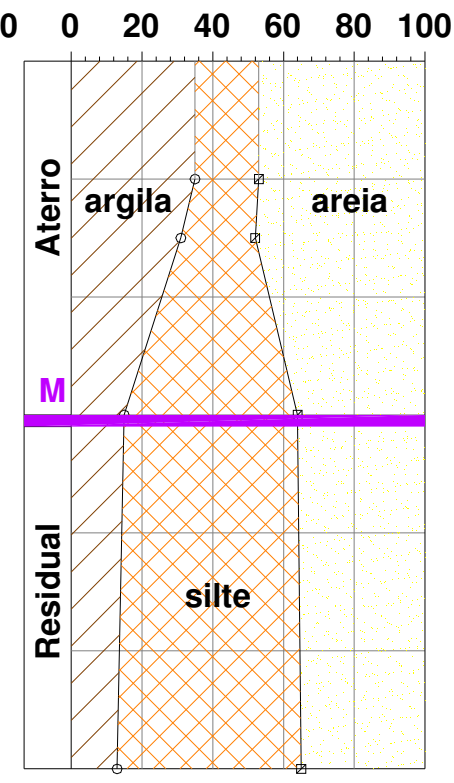

(c) ST-03

$\mathrm{M}$ - Contato com detritos vegetais

Figura 4.16: Granulometria das sondagens a trado (ST)

Os ensaios para determinação do peso específico dos grãos realizados com as amostras retiradas das sondagens a trado indicaram os resultados apresentados na Figura 4.17. O peso específico dos grãos médio do aterro argiloso é de $27,5 \mathrm{kN} / \mathrm{m}^{3}$ e do solo residual siltoso é de $27,3 \mathrm{kN} / \mathrm{m}^{3}$. Os desvios padrão dos resultados obtidos foram da ordem de $0,6 \mathrm{kN} / \mathrm{m}^{3}$ para o aterro e $0,5 \mathrm{kN} / \mathrm{m}^{3}$ para o solo residual. 


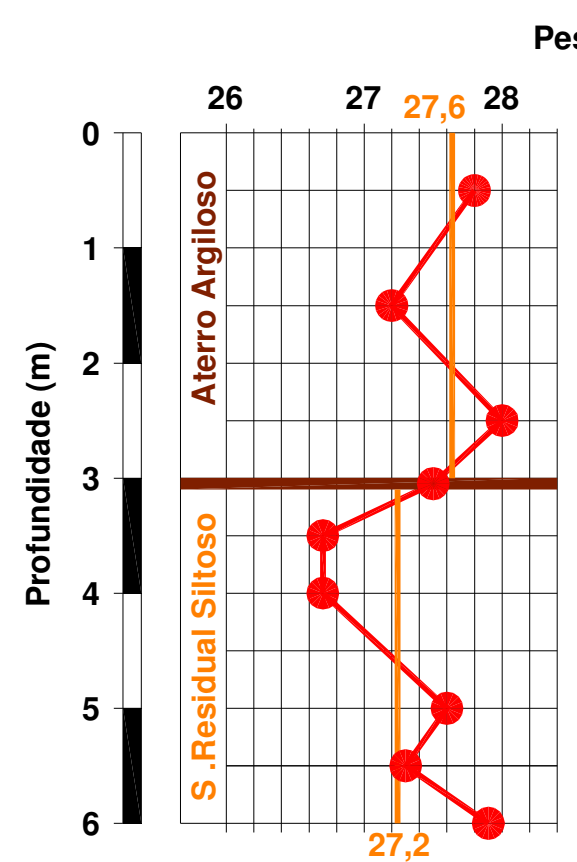

(a) ST-01

Peso Especifico dos Graos (kN/m3)

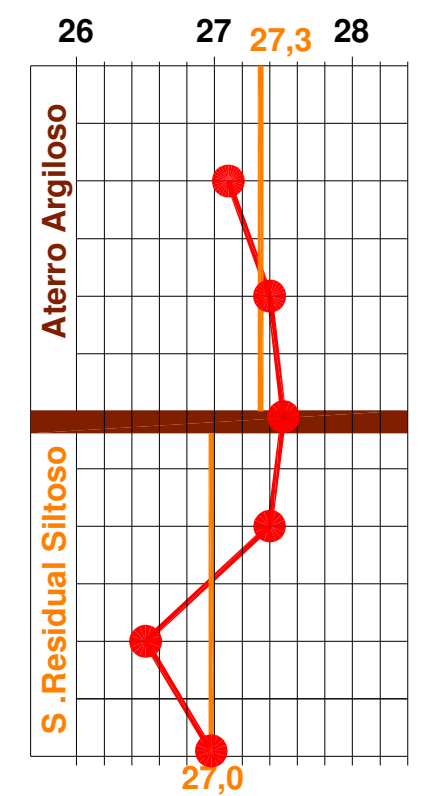

(b) ST-02

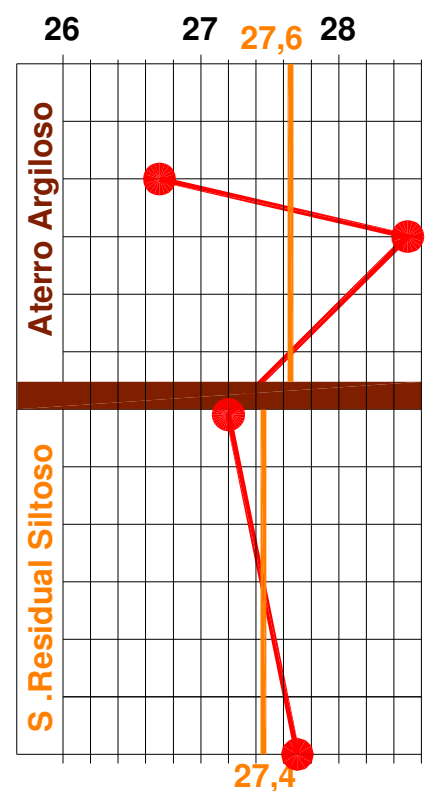

(c) ST-03

27,6 - valor medio do horizonte

Figura 4.17: Peso específico dos grãos $\mathrm{x}$ profundidade

Foram realizados ensaios para determinação dos índices físicos dos horizontes predominantes identificados. Foram utilizadas amostras retiradas dos blocos indeformados, coletados a um metro de profundidade.

A umidade natural determinada para a amostra do aterro (20,6\%) corresponde a um grau de saturação de $91,7 \%$, muito próximo da saturação, e para a amostra de solo residual o índice obtido foi de $15,5 \%$, que corresponde a um grau de saturação de $52,6 \%$ conforme mostrado na Tabela 4.3 .

O peso específico natural obtido para o aterro foi $20,5 \mathrm{kN} / \mathrm{m}^{3}$ e para o solo residual foi $17,8 \mathrm{kN} / \mathrm{m}^{3}$. O peso específico seco determinado para a amostra do aterro $(17,1$ $\mathrm{kN} / \mathrm{m}^{3}$ ) é elevado e corresponde a valor típico de um solo arenoso laterítico fino compactado, ou de uma areia silto-argilosa compactada (residual de granito), segundo dados de Pinto (2002). Ambas as caracterizações correspondem a solos compactados e podem se aplicar ao aterro ensaiado, o que corrobora a análise táctil visual feita em campo de que o aterro argiloso seria um solo compactado. 
Parece não haver dúvidas de que o aterro tem origem em ação antrópica, pois há um contato pouco espesso de solo argiloso com detritos vegetais, marrom escuro entre as duas camadas predominantes, encontrado nas três sondagens realizadas.

Tabela 4.3: Ensaios de caracterização com amostras dos blocos indeformados

\begin{tabular}{|c|c|c|c|c|c|c|c|c|c|c|}
\hline Material & $\mathrm{w}$ & $\mathrm{Sr}$ & $\gamma_{\text {nat }}$ & $\gamma_{\mathrm{d}}$ & $\gamma_{\mathrm{s}}$ & $\mathrm{e}$ & $\mathrm{w}_{\mathrm{L}}$ & $\mathrm{w}_{\mathrm{p}}$ & $\mathrm{I}_{\mathrm{P}}$ & Class. \\
\hline- & $(\%)$ & $(\%)$ & $(\mathrm{kN} / \mathrm{m} 3)$ & $(\mathrm{kN} / \mathrm{m} 3)$ & $(\mathrm{kN} / \mathrm{m} 3)$ & - & $(\%)$ & $(\%)$ & $(\%)$ & $\mathrm{USCS}$ \\
\hline Aterro & 20,6 & 91,7 & 20,5 & 17,1 & 27,5 & 0,60 & 43 & 29 & 14 & $\mathrm{ML} / \mathrm{CL}$ \\
\hline S.Residual & 15,5 & 52,6 & 17,8 & 15,5 & 27,3 & 0,76 & 40 & 36 & 4 & $\mathrm{ML}$ \\
\hline
\end{tabular}

Sendo: $w=$ umidade natural, $\gamma=$ peso específico natural, $\gamma_{\mathrm{s}}=$ massa específica dos sólidos, $\gamma_{d}=$ massa específica seca, e = índice de vazios, $\mathrm{Sr}=$ grau de saturação, $\mathrm{w}_{\mathrm{L}}$ $=$ limite de liquidez, $\mathrm{W}_{\mathrm{P}}=$ limite de plasticidade, $\mathrm{IP}=$ índice de plasticidade.

Os resultados dos ensaios para determinação dos Limites de Atterberg indicaram baixa plasticidade para ambos os solos analisados. $O$ aterro foi classificado como $\mathrm{CL}$ (argila de baixa plasticidade) e poderia ser classificado também como ML (silte de baixa plasticidade), pois está no limite entre os dois tipos de solo, conforme mostra a Figura 4.18. O solo residual é classificado como ML pela Classificação Unificada.

O baixo índice de plasticidade obtido para o aterro argiloso, $14 \%$, pode ser explicado pela elevada percentagem de areia, $47 \%$, presente no solo, e conforme visto anteriormente esse solo tem origem em sedimentos fluviais, incluindo argilitos, siltitos e arenitos, da Formação São Paulo. Pode-se supor, portanto, que o aterro argilo-arenoso analisado tenha origem predominante em arenitos da Formação São Paulo.

O índice de plasticidade obtido para o solo residual foi $4 \%$, valor esperado para um solo siltoso inorgânico de baixa compressibilidade. 


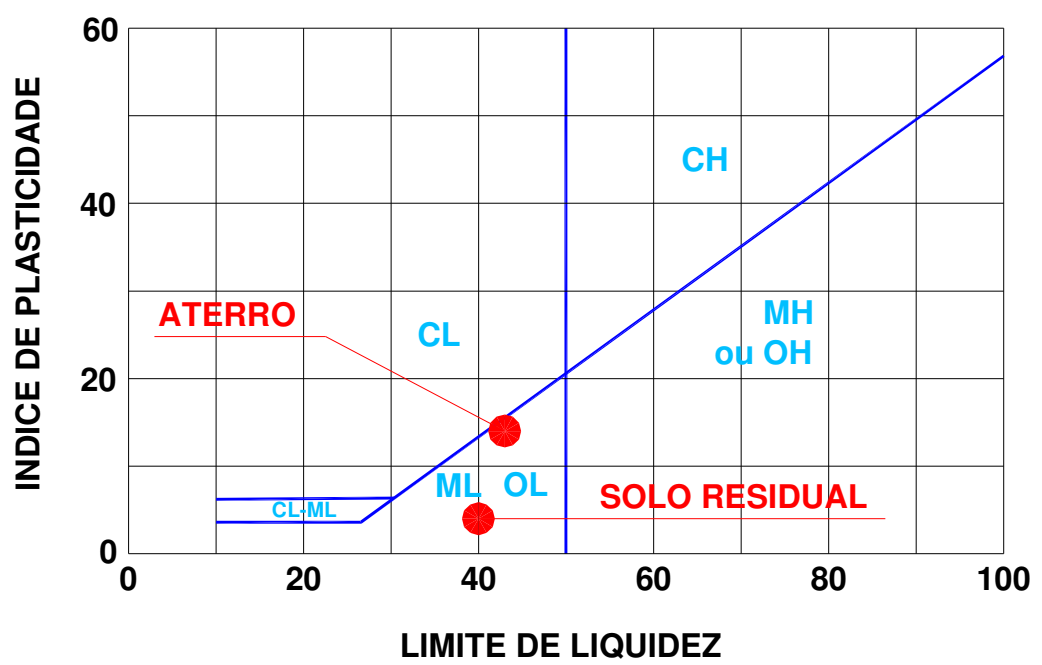

Figura 4.18: Carta de plasticidade

\subsubsection{Ensaios de permeabilidade}

\subsubsection{Em laboratório}

Foram realizados ensaios de permeabilidade em câmara Triflex com amostras indeformadas dos horizontes predominantes no talude cujos corpos de prova estão apresentados na Figura 4.19.

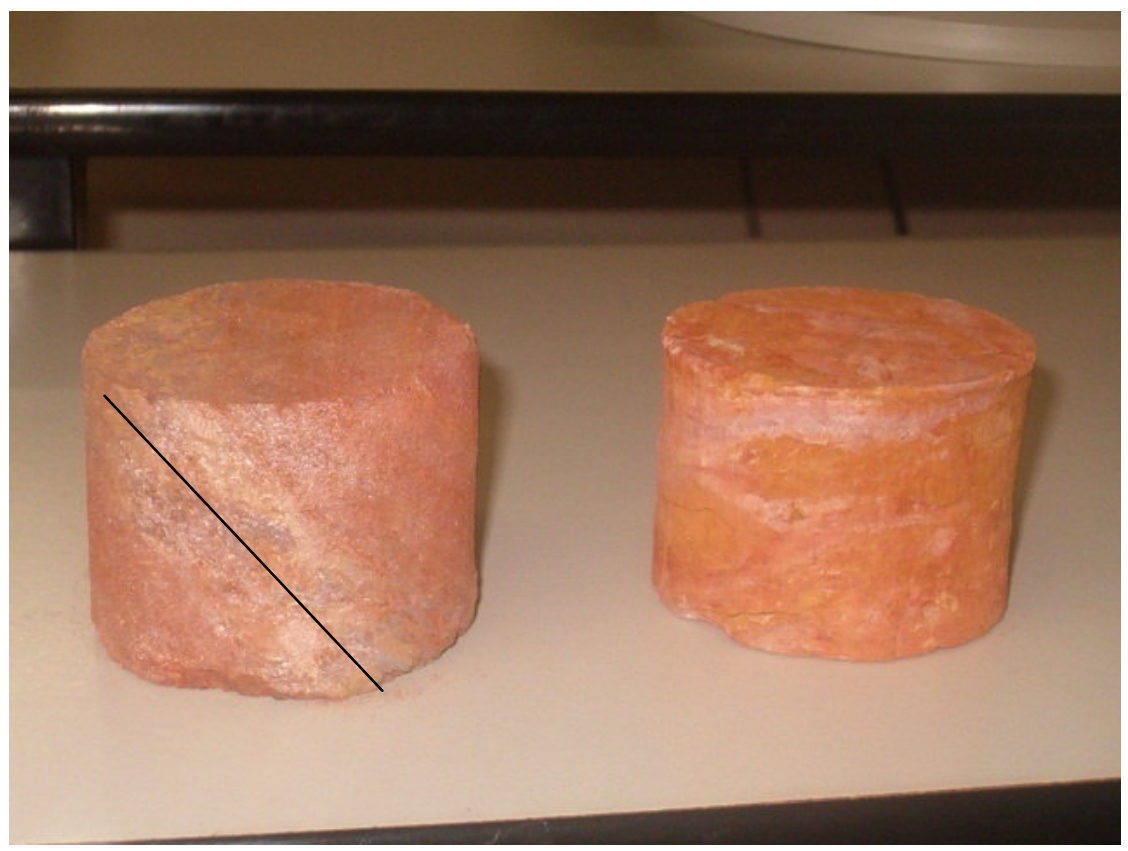

Figura 4.19: Fotos dos corpos de prova do solo residual (e), observar direção do plano de foliação indicada na figura, e do aterro (d). 
Os corpos de prova foram saturados e submetidos a diferentes pressões de confinamento. Para cada pressão de confinamento o coeficiente de permeabilidade foi determinado. $O$ ensaio foi repetido para diferentes posições de moldagem dos corpos de prova, verticalmente e horizontalmente para ambos os solos, e a $45^{\circ}$ para o solo residual, por se tratar de solo com plano de foliação bem definido nessa inclinação, conforme mostrado na Figura 4.19.

Observou-se que os valores de coeficiente de permeabilidade obtidos para as várias pressões de confinamento utilizadas variaram pouco, conforme mostrado na Figura 4.20. Isso indica que os solos ensaiados são pouco compressíveis e provavelmente "sobreadensados". As pressões de confinamento aplicadas nos ensaios foram: 50, 60,100 e $150 \mathrm{kPa}$, e para cada uma foi medido o coeficiente de permeabilidade do solo. A diferença de pressão entre a base e o topo dos corpos de prova utilizada no ensaio foi de $10 \mathrm{kPa}$.

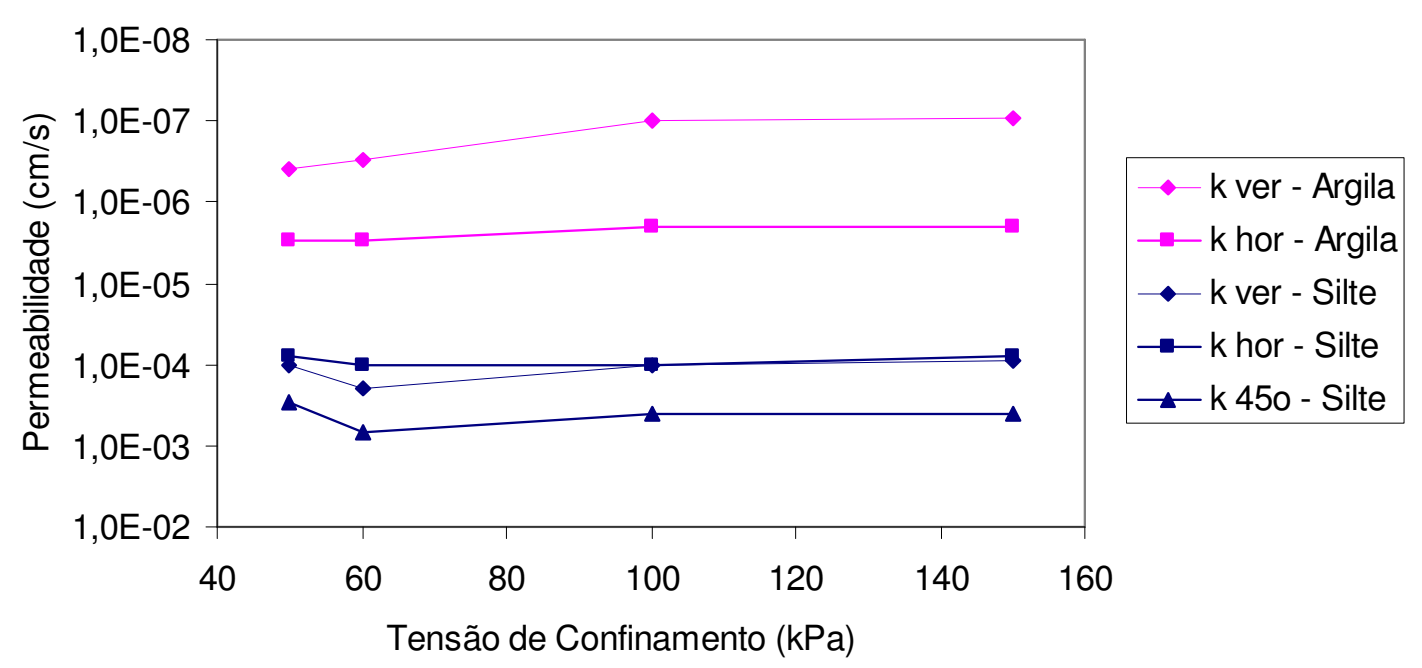

Figura 4.20: Variação do coeficiente de permeabilidade com a tensão confinante

A decisão de se determinar o coeficiente de permeabilidade em diferentes direções, conforme mostrado na Figura 4.21, foi tomada por se tratar de aterro supostamente compactado, para o qual se esperava um coeficiente de permeabilidade horizontal cerca de cinco a dez vezes maior que o vertical. E para o solo residual siltoso 
esperavam-se coeficientes de permeabilidade vertical e horizontal de valores próximos, e permeabilidade a $45^{\circ}$ maior que as demais, em função da existência do plano de foliação.

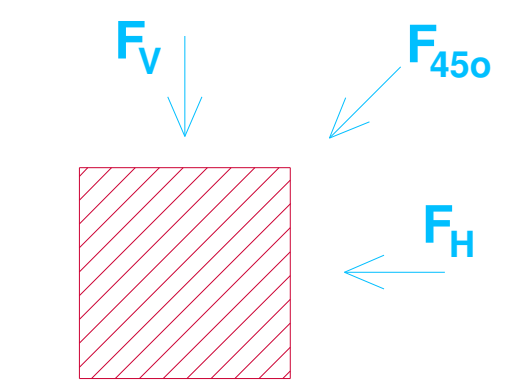

SOLO RESIDUAL

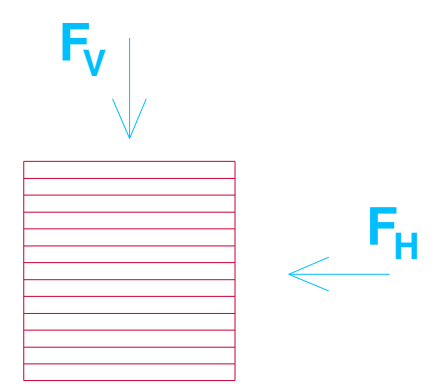

ATERRO

Figura 4.21: Direção dos fluxos $\left(F_{V}, F_{H}, F_{45^{\circ}}\right)$ aplicados a amostras retiradas dos blocos indeformados

Os resultados obtidos nos ensaios de permeabilidade são compatíveis com os esperados para solos com as granulometrias dos solos ensaiados. Os vetores permeabilidade que indicam sua direção e magnitude estão mostrados na Figura 4.12.

O coeficiente de permeabilidade vertical do silte $\left(1,2 \times 10^{-4} \mathrm{~cm} / \mathrm{s}\right)$ têm valor próximo de seu coeficiente de permeabilidade horizontal $\left(9,0 \times 10^{-5} \mathbf{c m} / \mathbf{s}\right)$, ou 1,4 vez maior. 0 coeficiente de permeabilidade a $45^{\circ}$ do silte $\left(4,5 \times 10^{-4} \mathrm{~cm} / \mathrm{s}\right)$ é cinco vezes maior que seu coeficiente de permeabilidade horizontal, por se tratar de fluxo na direção do plano de foliação do solo. O coeficiente de permeabilidade horizontal da argila $\left(2,5 \times 10^{-6} \mathrm{~cm} / \mathrm{s}\right)$ é 11,4 vezes maior que seu coeficiente de permeabilidade vertical $\left(2,2 \times 10^{-7} \mathrm{~cm} / \mathrm{s}\right)$, conforme esperado por se tratar de solo compactado.

O coeficiente de permeabilidade saturado da argila é significativamente menor que o do silte, conforme pode ser observado na Figura 4.12 onde os vetores permeabilidade do aterro argiloso praticamente somem quando desenhados na mesma escala dos vetores permeabilidade do solo residual siltoso. 
Observando-se os vetores dos coeficientes de permeabilidade apresentados na Figura 4.22 espera-se que os fluxos de águas de chuva no maciço do talude experimental ocorram preferencialmente na direção dos planos de foliação do solo residual, que fazem um ângulo de cerca de $45^{\circ} \mathrm{com}$ a horizontal.

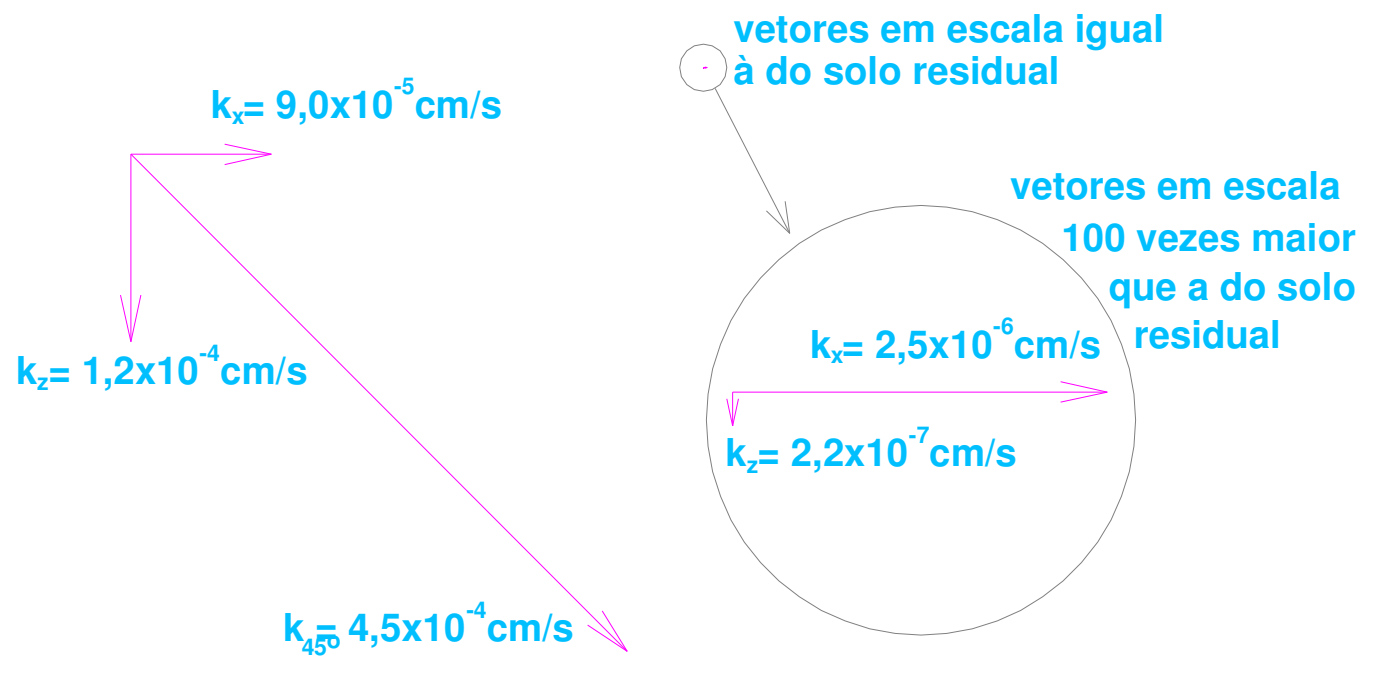

SOLO RESIDUAL

ATERRO

Figura 4.22: Vetores dos coeficientes de permeabilidade, indicando magnitude e direção.

\subsubsection{Em campo}

Os ensaios de permeabilidade Guelph consistiram em executar furos com 3,0 cm de diâmetro e $30 \mathrm{~cm}$ de profundidade no aterro argiloso e no solo residual siltoso, no campo experimental. A seguir foram feitos ensaios de infiltração com carga constante nos furos executados, conforme apresentado na Figura 4.23. Os resultados obtidos indicaram coeficientes de permeabilidade do aterro argiloso de $2,0 \times 10^{-7} \mathrm{~cm} / \mathrm{s}$ e do solo residual siltoso de $2,0 \times 10^{-4} \mathrm{~cm} / \mathrm{s}$. Os resultados obtidos são compatíveis com os obtidos nos ensaio realizados em laboratório: $2,2 \times 10^{-7} \mathrm{~cm} / \mathrm{s}$ para o coeficiente de permeabilidade horizontal do aterro e $9,0 \times 10^{-5} \mathrm{~cm} / \mathrm{s}$ para 0 coeficiente de permeabilidade horizontal do solo residual, conforme apresentado no item 4.2.2.1. 


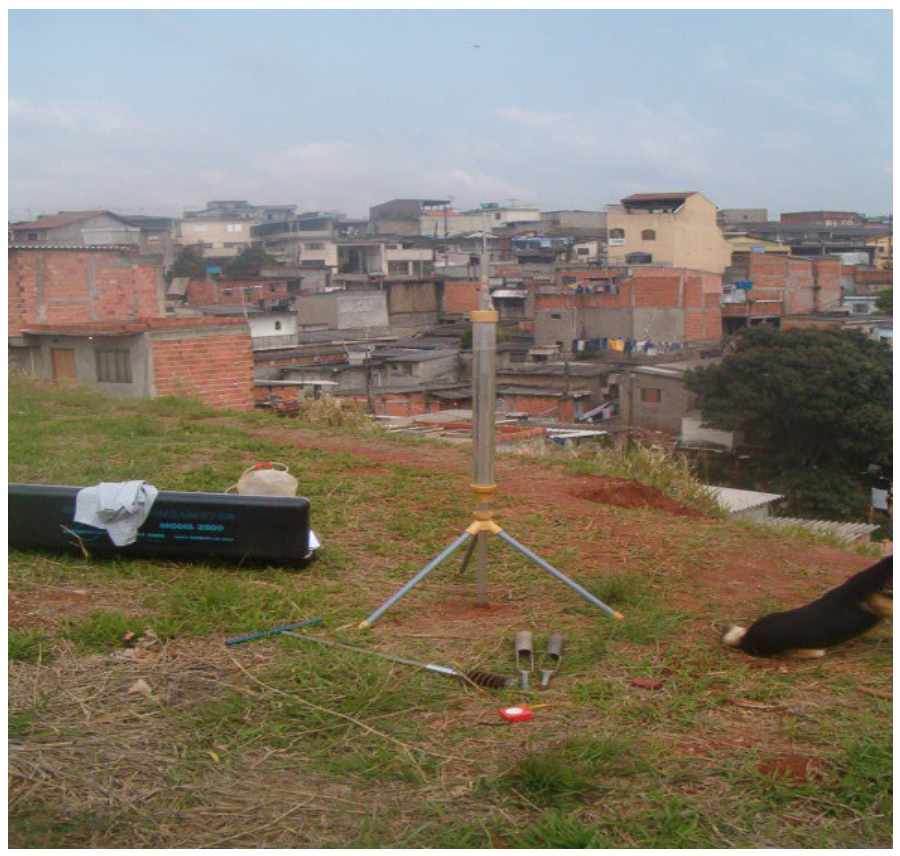

Figura 4.23: Ensaio de Permeabilidade Guelph

\subsubsection{Curva de retenção e função permeabilidade}

Foram moldados quatro corpos de prova de solo indeformado sendo dois do aterro argiloso e dois do solo residual siltoso com o objetivo de se determinar as curvas de retenção pelo caminho de secagem.

A moldagem foi feita concomitantemente à inserção dos corpos de prova em anéis de PVC de forma que suas faces cilíndricas estivessem encostadas nas superfícies internas dos anéis. As faces superior e inferior dos corpos de prova foram regularizadas no alinhamento das extremidades dos anéis.

Os corpos de prova foram colocados em placa de sucção de forma que o nível d'água do reservatório ficasse na metade da altura dos corpos de prova. Foram deixados por dez dias para saturar, até que seus pesos ficassem constantes.

O ensaio se iniciou com a aplicação de $1 \mathrm{Kpa}$ de sucção. Foram feitas pesagens diárias dos corpos de prova até que os pesos se estabilizassem, o que ocorreu doze 
dias após. O tempo de estabilização para a argila foi maior que para silte, devido à diferença de permeabilidade. O procedimento foi repetido para diversas sucções até $30 \mathrm{kPa}$, com tempo médio de estabilização de sete dias.

Em seguida os corpos de prova foram levados a uma placa de pressão para determinação da umidade em diversas pressões que variaram entre 50 e $300 \mathrm{kPa}$. O tempo médio de estabilização das leituras foi de dez dias. Para completar as curvas de retenção foram feitas medições de sucção pela técnica do papel filtro para diversas umidades.

As Figuras 4.24 e 4.25 apresentam as curvas de retenção do aterro argiloso e do solo residual siltoso, respectivamente, em três formas distintas:

(a) Sucção versus Umidade Volumétrica;

(b) Sucção versus Umidade Gravimétrica;

(c) Sucção versus Grau de Saturação; e,

(d) Sucção versus índice de vazios.

O valor de entrada de ar do aterro argiloso é $150 \mathrm{kPa}$ e do solo residual siltoso é 4 kPa conforme indicado nas Figuras 4.24 (a) e 4.25 (a), respectivamente.

Nas Figuras 4.24 (a) e 4.25 (a) são apresentados os ajustes das curvas de retenção em função da umidade volumétrica por meio das equações matemáticas propostas por Fredlund e Xing (1994) e por van Genuchten (1980), para o aterro argiloso e o solo residual siltoso, respectivamente. De uma maneira geral os ajustes se aproximaram dos valores obtidos em laboratório. 

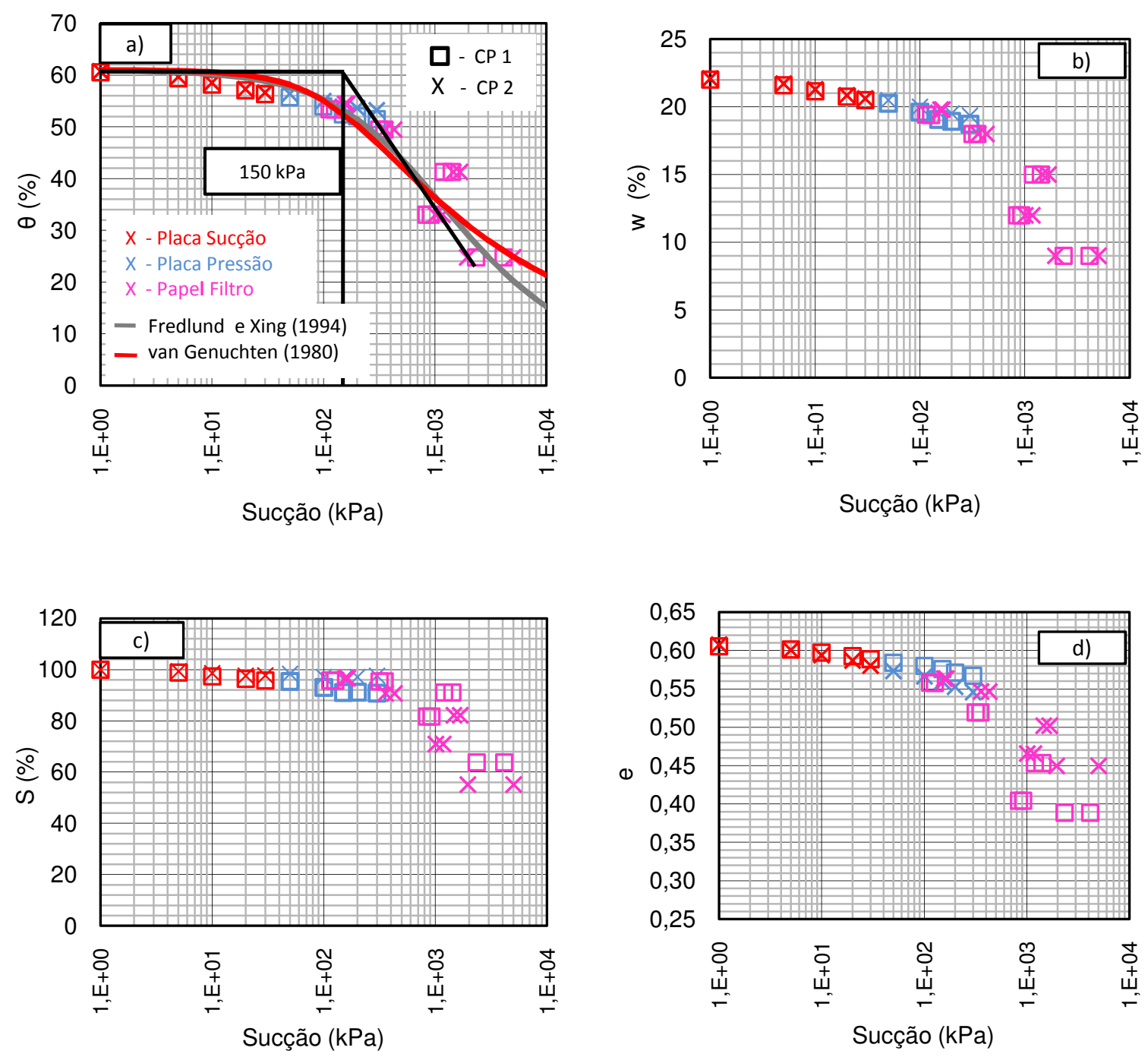

Figura 4.24: Curva de retenção para o aterro argiloso: a) relação entre umidade volumétrica e sucção; b) relação entre umidade gravimétrica e sucção; c) relação entre grau de saturação e sucção; e d) relação entre índice de vazios e sucção.

As constantes do ajuste a, $n$ e $m$, segundo Fredlund e Xing (1994), para o aterro argiloso são respectivamente 600, 0,867 e 1,355 e a umidade volumétrica saturada, $\theta$ s, $61 \%$. Para o solo residual sitoso as constantes do ajuste $a, n$ e $m$ são $16,1,315$ e 0,763 , respectivamente, e a umidade volumétrica saturada, $\theta$ s, $76 \%$.

As constantes do ajuste $\alpha, n$ e $m$, segundo van Genuchten (1980), para o aterro argiloso são respectivamente $0,007,1,288$ e 0,224. Para o solo residual sitoso as constantes do ajuste $\alpha, n$ e $m$ são $0,067,1,470$ e 0,320, respectivamente. 

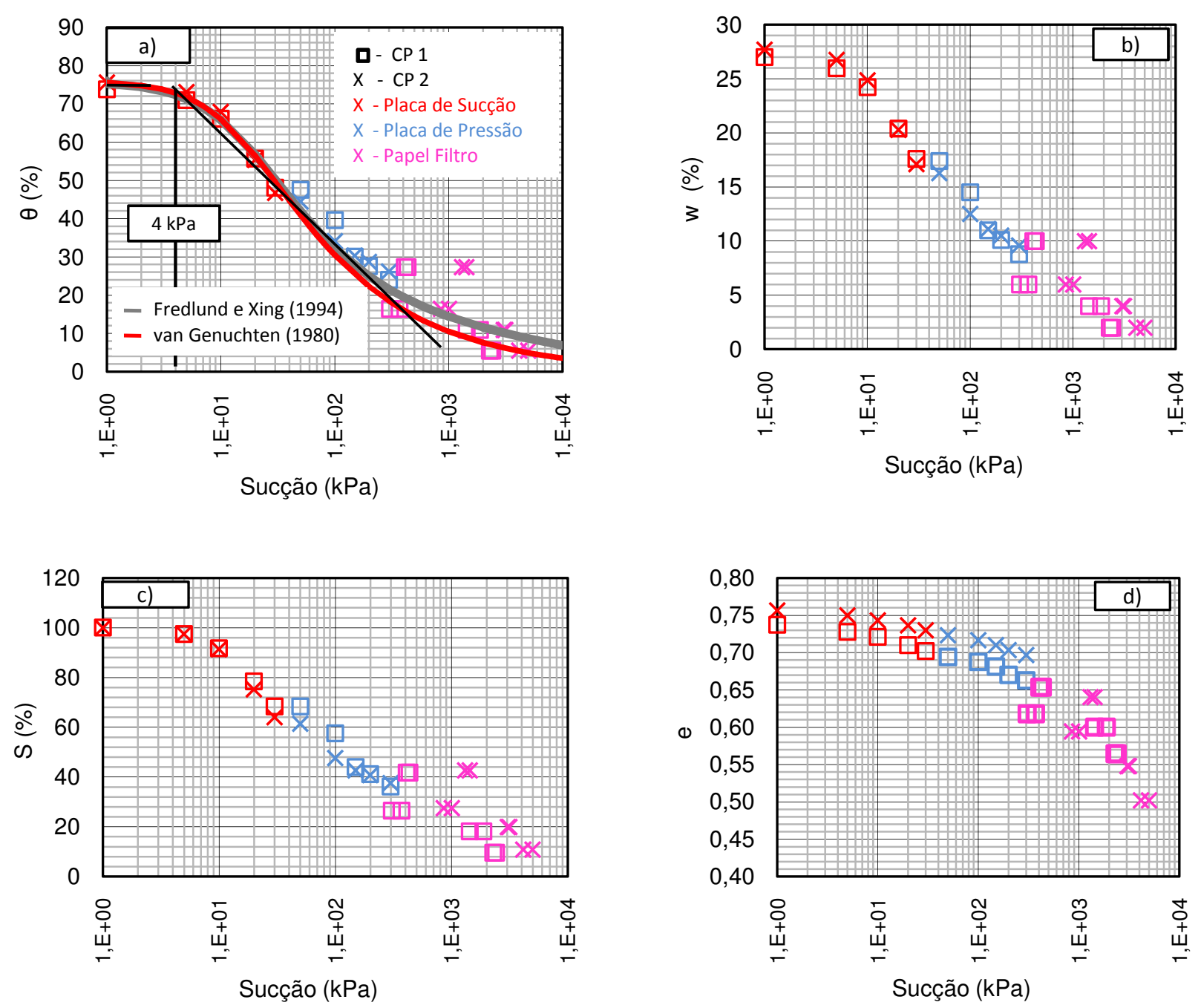

Figura 4.25: Curva de retenção para o solo residual siltoso: a) relação entre umidade volumétrica e sucção; b) relação entre umidade gravimétrica e sucção; c) relação entre grau de saturação e sucção; e d) relação entre índice de vazios e sucção.

A função condutividade hidráulica dos solos estudados foi obtida a partir de expressões analíticas desenvolvidas por van Genuchten (1980) que se baseiam em modelo de previsão de condutividade hidráulica relativa desenvolvido por Y. Mualem, e em parâmetros obtidos no ajuste da curva de retenção a dados experimentais. A função condutividade hidráulica obtida para 0 aterro argiloso indica condutividade hidráulica saturada até sucção de $150 \mathrm{kPa}$, conforme pode ser visto na Figura 4.26. Esse resultado está de acordo com o valor de entrada de ar do solo, de cerca de $150 \mathrm{kPa}$. Considerando que até esse valor pouco ou nenhum ar penetra nos poros 
do solo, seria de se esperar que sua condutividade hidráulica nessa faixa de poropressões fosse muito próxima da saturada. As formas das curvas função condutividade hidráulica obtidas para ambos os solos indicam, conforme esperado, redução da condutividade hidráulica com a elevação da sucção.

As condutividades hidráulicas saturadas dos solos estudados variam com a direção do fluxo, conforme apresentado no item anterior deste trabalho. A Figura 4.26 foi elaborada considerando as condutividades hidráulicas saturadas na direção a $45^{\circ}$ com a horizontal, $1,4 \times 10^{-6} \mathrm{~cm} / \mathrm{s}$ para a argila e $4,5 \times 10^{-4} \mathrm{~cm} / \mathrm{s}$ para o silte, considerando que é nessa direção, ou próximo dela que se esperam os maiores fluxos de água no talude experimental.

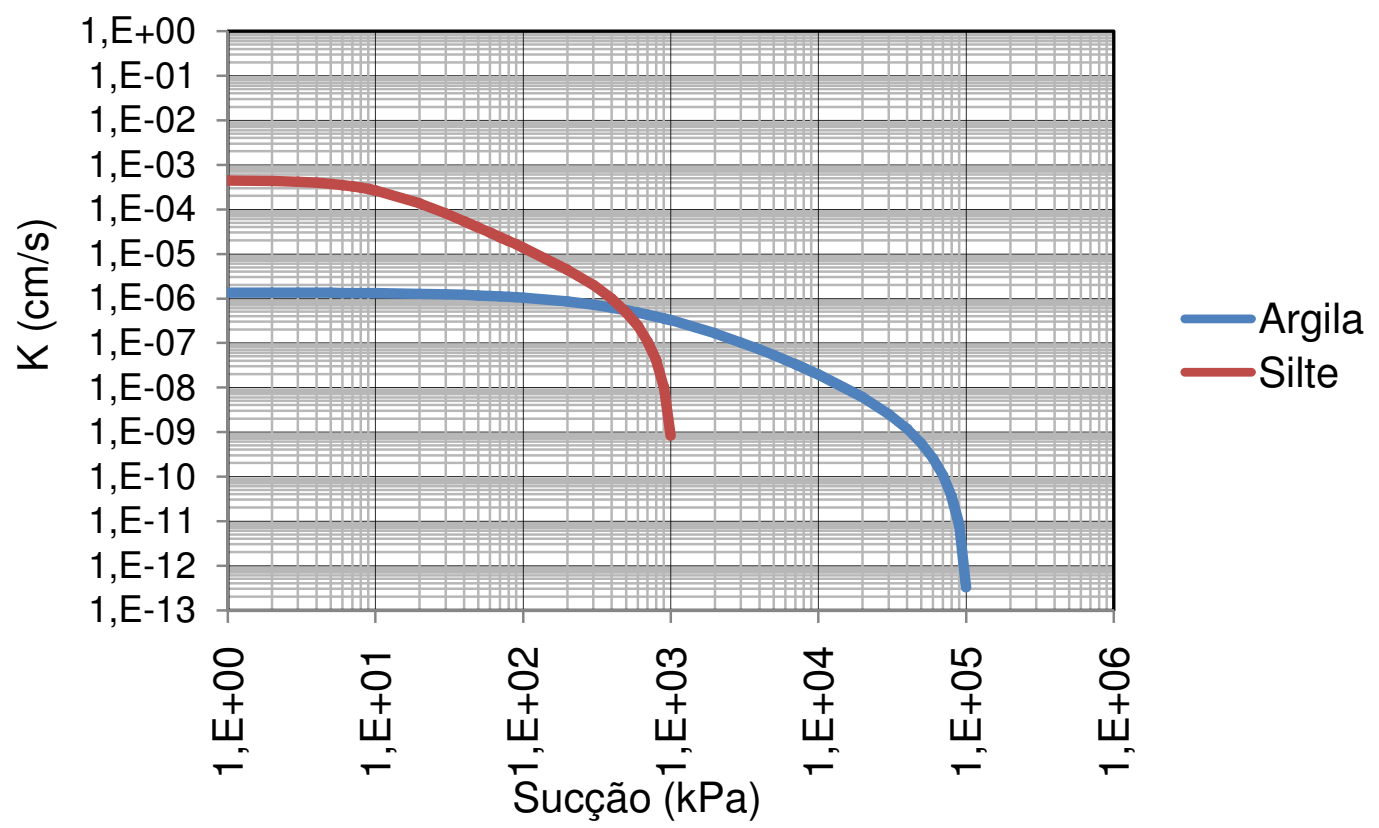

Figura 4.26: Função condutividade hidráulica do aterro argiloso e do solo residual siltoso, na direção $45^{\circ} \mathrm{com}$ a horizontal.

Observa-se na Figura 4.26 que a condutividade hidráulica do silte é maior que a da argila para sucções menores que $500 \mathrm{kPa}$, e para sucções maiores que $500 \mathrm{kPa} a$ condutividade da argila é maior que a do silte. Não se espera que ocorram sucções maiores que $500 \mathrm{kPa}$ em campo, conforme resultados de leituras a serem 
apresentadas mais à frente neste trabalho. Isso indica que o silte deve apresentar permeabilidade maior que a da argila, em campo, durante todo o ano inclusive nos períodos de estiagem.

\subsubsection{Ensaios para determinação da resistência não saturada}

Apresentam-se a seguir os resultados de ensaios de cisalhamento direto e compressão simples realizados no aterro argiloso e no solo residual siltoso.

\subsubsection{Aterro argiloso}

Foram realizados ensaios de cisalhamento direto com amostras do aterro argiloso nas condições inundada e não saturada, e ensaios de compressão simples com amostras não saturadas. Apresentam-se a seguir os resultados obtidos e análises desses resultados:

\section{Ensaios de cisalhamento direto}

Foram realizados ensaios de cisalhamento direto com amostras indeformadas do aterro argiloso, retiradas do campo experimental. Foram feitos três grupos de ensaios, sendo:

(a) inundados com tensões normais de 20,50, 100, 200 e $500 \mathrm{kPa}$;

(b) não saturados, com sucção ao final do experimento de $130 \mathrm{kPa}$ aproximadamente, com tensões normais de 20,50 e $200 \mathrm{kPa}$. O procedimento para a realização desses ensaios foi: (1) moldagem dos corpos de prova na umidade natural em que se encontravam no bloco indeformado; (2) execução do ensaio de cisalhamento direto padronizado; e (3) medição da sucção pelo método do papel filtro ao final do ensaio, tomando-se o cuidado de embalar as amostras em papel filme e papel alumínio para que não perdessem umidade para o ambiente. $O$ 
resultado obtido para a resistência ao cisalhamento do ensaio com tensão normal igual a 50 kPa não apresentou coerência com os demais e não foi apresentado; e,

(c) não saturados com tensão normal de $50 \mathrm{kPa}$, com sucções variadas de aproximadamente 50 e $200 \mathrm{kPa}$, e um terceiro ensaio foi realizado com o corpo de prova seco ao ar até que seu peso se estabilizasse. O tempo de secagem foi de cerca de 30 dias e a umidade residual foi de cerca de $1 \%$. Ao final da execução dos três ensaios a sucção dos corpos de prova foi medidas com tensiômetro de alta capacidade.

Analisou-se a variação dos deslocamentos horizontais ocorridos durantes os ensaios acima em função dos deslocamentos verticais, e verificou-se que os ensaios realizados com a argila inundada, com tensões normais iguais a 100, 200 e $500 \mathrm{kPa}$, apresentaram redução de volume do corpo de prova de cerca de 1,6 \% (Fig.4.27).

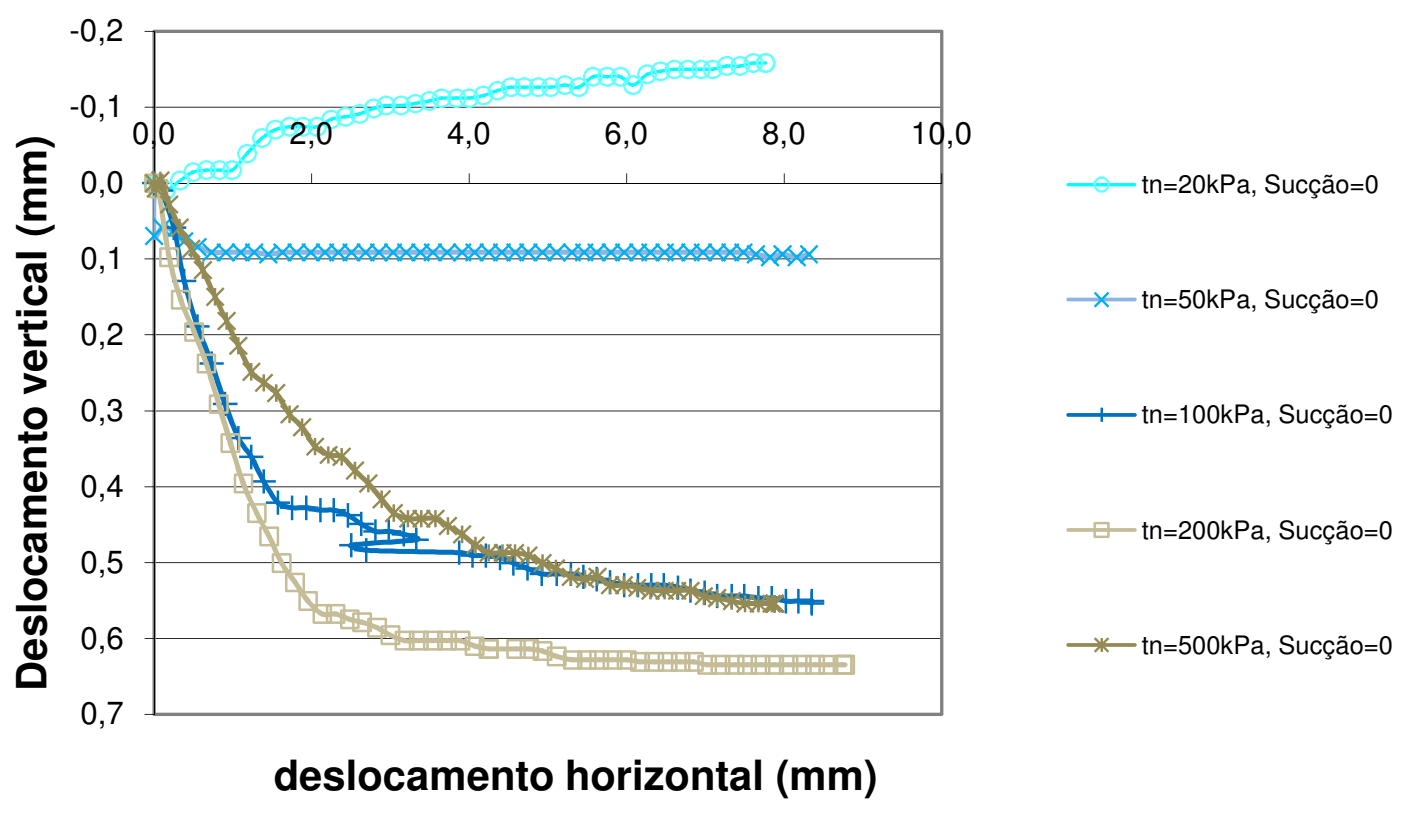

Figura 4.27: Gráfico do deslocamento vertical em função do deslocamento horizontal, nos ensaios com a argila inundada, de acordo com a tensão vertical aplicada 
O ensaio inundado com tensão normal igual $50 \mathrm{kPa}$ também apresentou comportamento compressivo, com variação de volume, menor, de cerca de $0,3 \%$. E o ensaio com tensão normal igual $20 \mathrm{kPa}$ apresentou dilatância com variação de volume de cerca de $0,4 \%$.

No gráfico da Figura 4.28 é apresentada a variação da tensão cisalhante em função do deslocamento horizontal durante os ensaios de cisalhamento direto realizados com a argila inundada. De uma maneira geral as tensões cisalhantes máximas foram tanto maiores quanto maiores as tensões normais aplicadas ao corpo de prova.

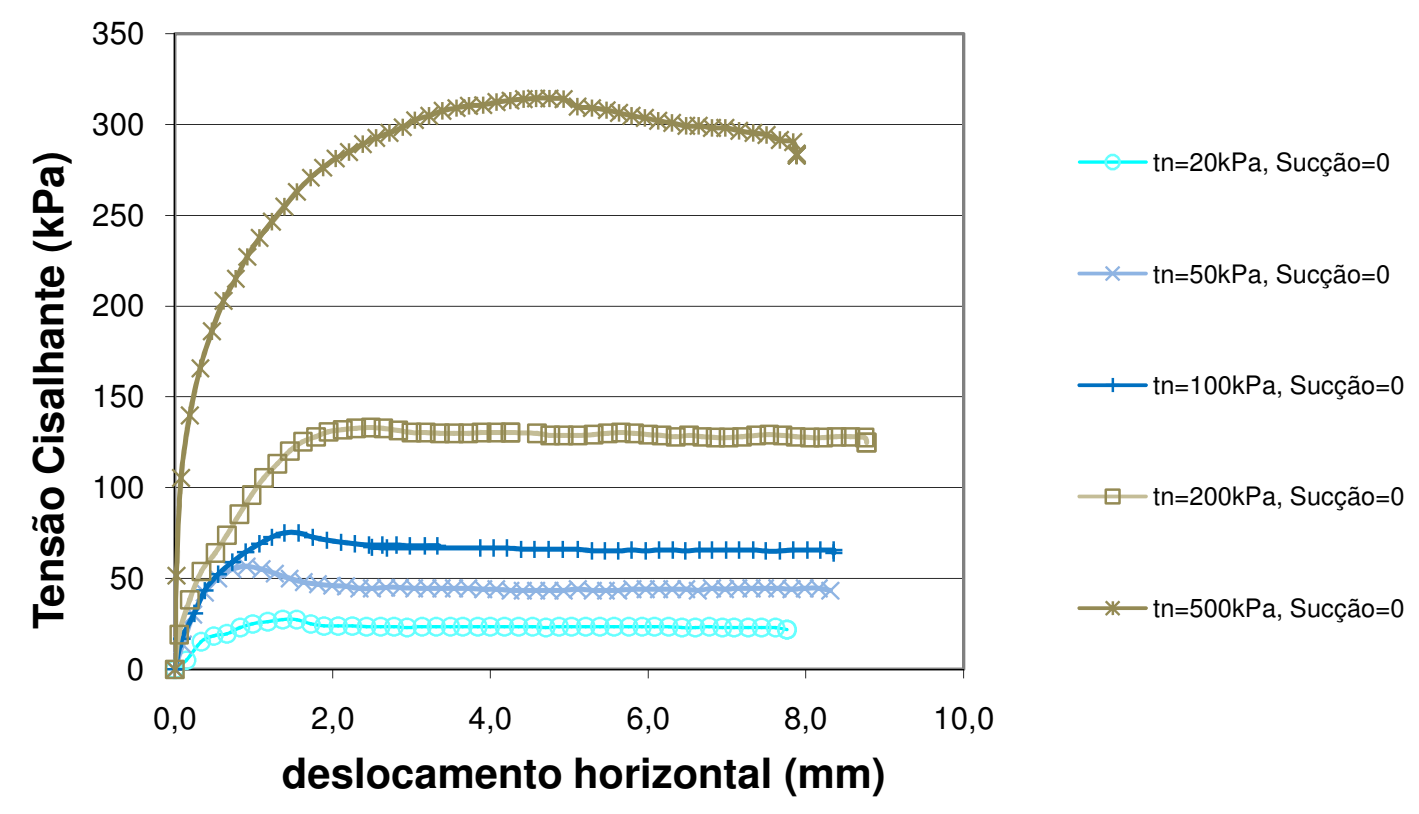

Figura 4.28: Gráfico da tensão cisalhante em função do deslocamento horizontal, nos ensaios com a argila inundada, de acordo com a tensão vertical aplicada

Os ensaios não saturados realizados em amostras da argila com mesma sucção, $130 \mathrm{kPa}$, indicaram dilatância para o ensaio com tensão normal igual a $20 \mathrm{kPa}$, e comportamento compressivo para o ensaio realizado com tensão normal igual a 200 $\mathrm{kPa}$, conforme pode ser visto na Figura 4.29. Os ensaios não saturados realizados com mesma tensão normal, $50 \mathrm{kPa}$, apresentaram dilatância crescente com a sucção do corpo de prova, 50 e $200 \mathrm{kPa}$. O corpo de prova seco ao ar apresentou 
redução da dilatância em relação ao corpo de prova ensaiado com sucção igual a $200 \mathrm{kPa}$.

Observa-se que o corpo de prova seco ao ar também apresentou redução da resistência de pico em relação ao corpo de prova ensaiado com tensão normal igual a $200 \mathrm{kPa}$, conforme pode ser visto na Figura 4.30. Esse resultado pode indicar que devido à pequena quantidade de água no solo, a sucção matricial não fosse aplicada a todas as partículas de solo, reduzindo sua resistência ao cisalhamento. A forma da curva da tensão cisalhante em função do deslocamento horizontal pode indicar também que houve efeito de perda de cimentação entre as partículas do solo, porém a curva deslocamento vertical em função do deslocamento horizontal indicou comportamento incomum nesses casos, isto é, continuidade da dilatância após a ruptura.

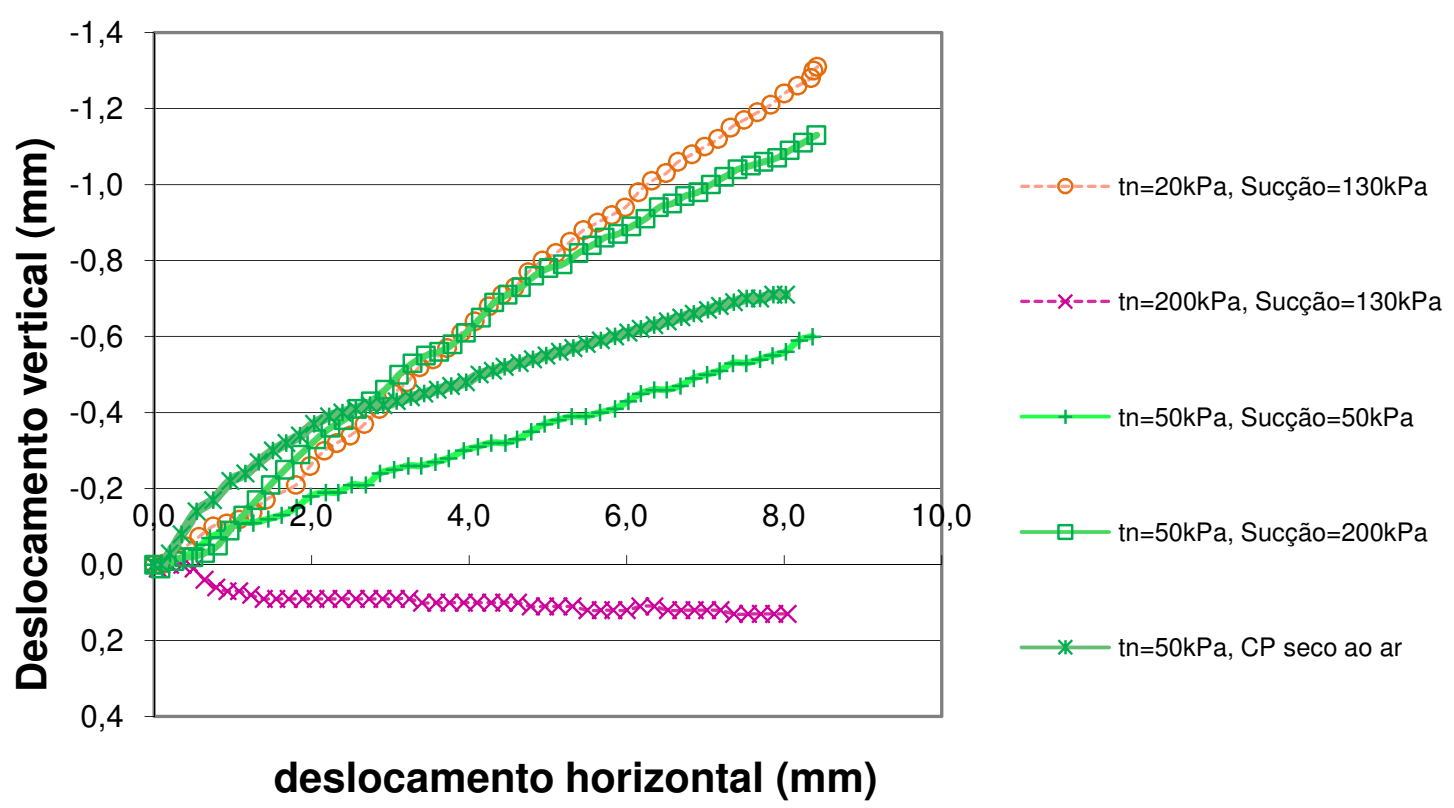

Figura 4.29: Gráfico do deslocamento vertical em função do deslocamento horizontal, nos ensaios com a argila não saturada, de acordo com a tensão vertical aplicada e com a sucção do corpo de prova ao final do ensaio

Os demais corpos de prova não saturados apresentaram tensões cisalhantes máximas tanto maiores quanto maiores as tensões normais aplicadas e quanto maior a sucção do corpo de prova. 


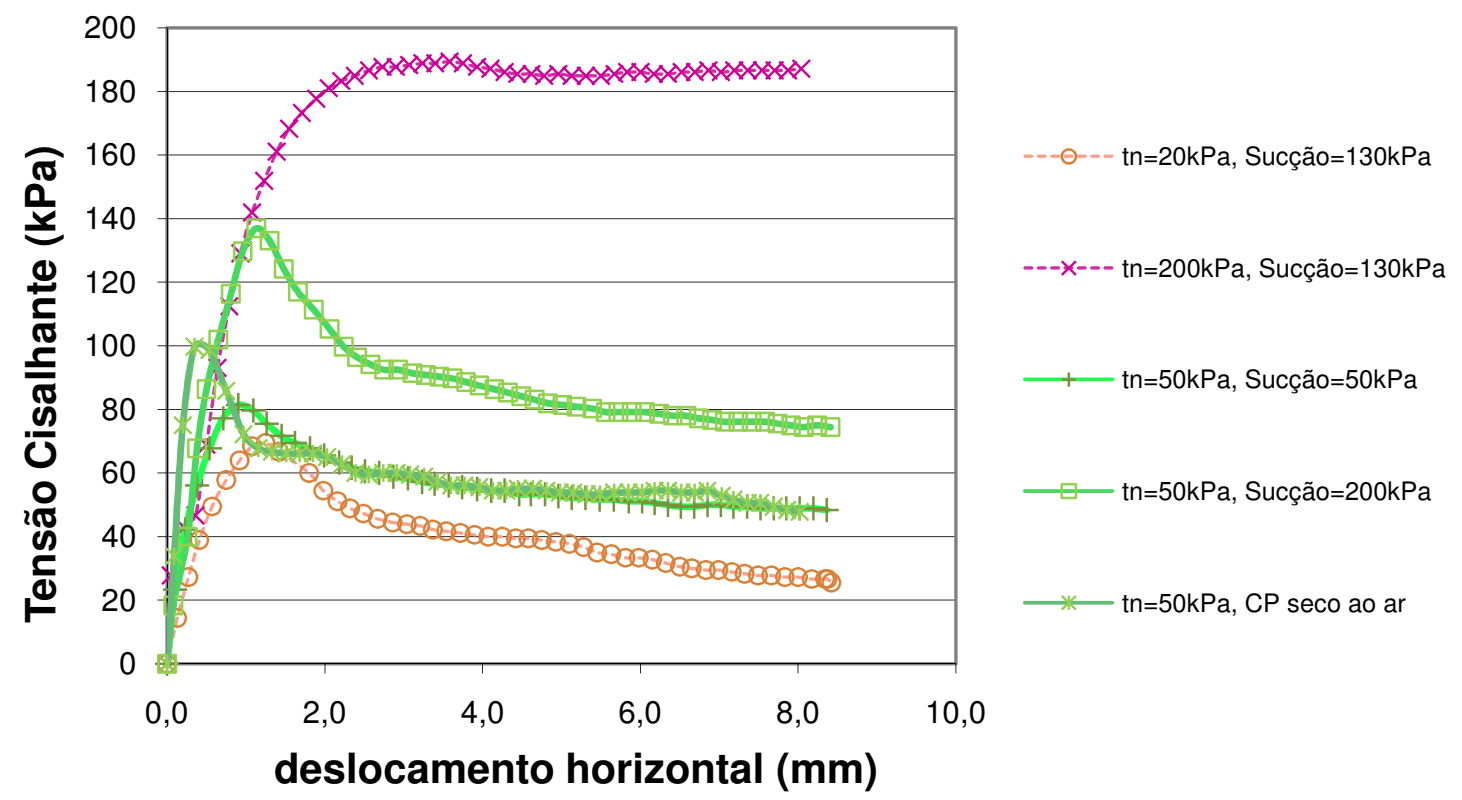

Figura 4.30: Gráfico da tensão cisalhante em função do deslocamento horizontal, nos ensaios com a argila não saturada, de acordo com a tensão vertical aplicada e com a sucção do corpo de prova ao final do ensaio

Os ensaios de cisalhamento direto no aterro argiloso apresentaram os seguintes resultados para a tensão de cisalhamento de pico, de acordo com a tensão normal aplicada e sucção medida após a ruptura (Tabela 4.4):

Tabela 4.4: Resistência ao cisalhamento do aterro argiloso medida em ensaios de cisalhamento direto inundado e não saturado

\begin{tabular}{|c|c|c|}
\hline $\begin{array}{c}\text { Tensão } \\
\text { Normal }\end{array}$ & $\begin{array}{c}\text { Sucção na } \\
\text { Ruptura }\end{array}$ & $\begin{array}{c}\text { Tensão de } \\
\text { Cisalhamento } \\
\text { na Ruptura }\end{array}$ \\
\hline$(\mathrm{kPa})$ & $(\mathrm{kPa})$ & $(\mathrm{kPa})$ \\
\hline 20 & 0 & 27 \\
\hline 50 & 0 & 57 \\
\hline 100 & 0 & 76 \\
\hline 200 & 0 & 133 \\
\hline 500 & 0 & 315 \\
\hline 20 & 130 & 70 \\
\hline 50 & 50 & 81 \\
\hline 50 & 200 & 137 \\
\hline 200 & 130 & 189 \\
\hline 50 & seco ao ar & 100 \\
\hline
\end{tabular}


A envoltória de resistência obtida para 0 aterro inundado resultou nos seguintes parâmetros geotécnicos: ângulo de atrito efetivo de $31^{\circ}$ e coesão efetiva de $15 \mathrm{kPa}$. São apresentadas na Figura 4.31 as envoltórias de resistência para sucções iguais a 0, 50, 130 e $200 \mathrm{kPa}$, além de envoltória para o solo seco ao ar.

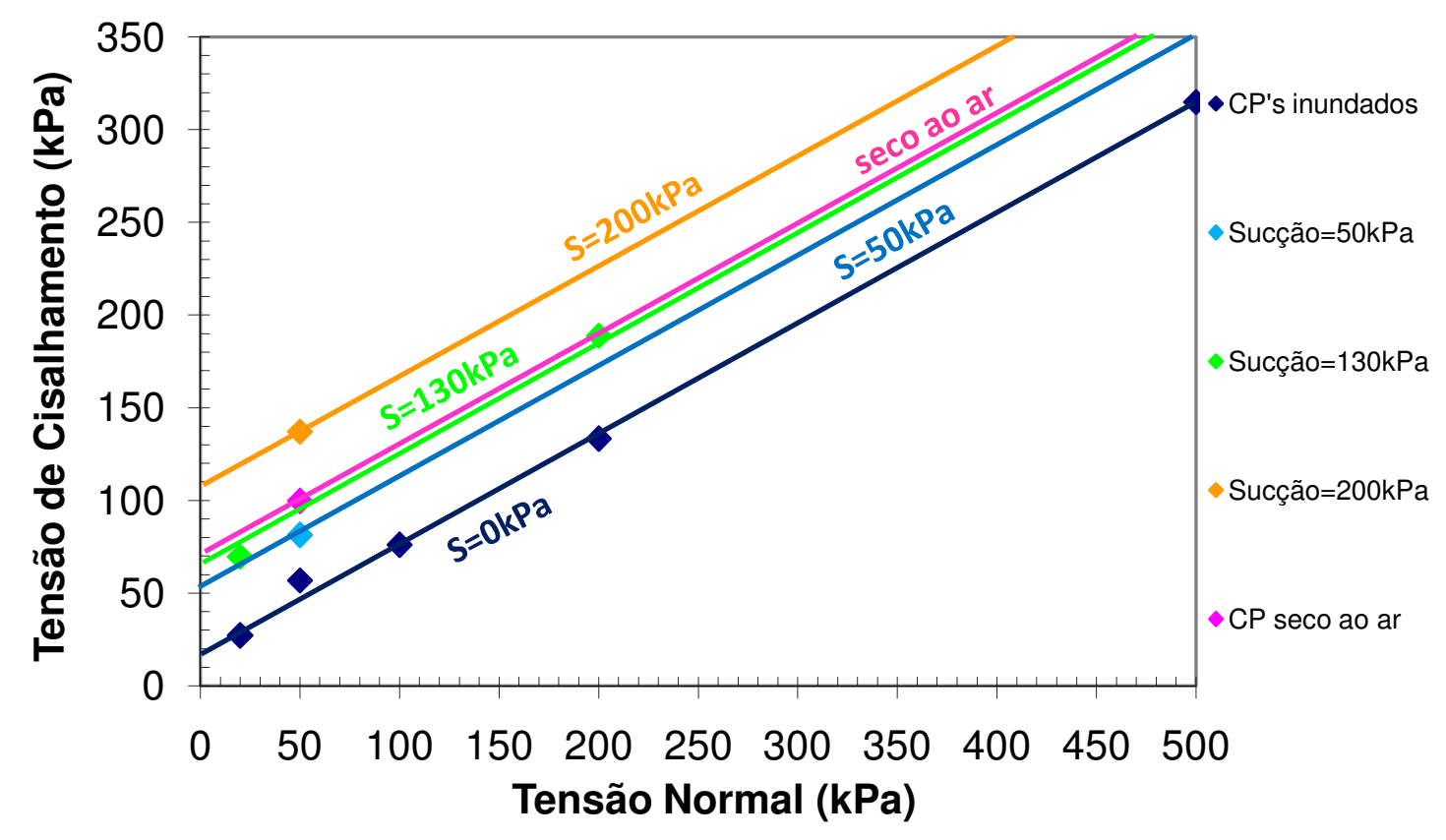

Figura 4.31.: Envoltórias de resistência da argila, para os ensaios de cisalhamento direto inundados e não saturados

Analisando-se os resultados obtidos segundo as equações propostas por Bishop (1959) e por Fredlund et al. (1978) para solos não saturados obteve-se os parâmetro $\phi^{b}$ e $\chi$ apresentados na Tabela 4.5.

Tabela 4.5.: Parâmetros de resistência ao cisalhamento do aterro argiloso não saturado obtidos em ensaios de cisalhamento direto não saturado

\begin{tabular}{|c|c|c|c|}
\hline $\begin{array}{c}\text { Tensão } \\
\text { Normal }\end{array}$ & Sucção & $\chi$ & $\phi^{b}$ \\
\hline$(\mathrm{kPa})$ & $(\mathrm{kPa})$ & & $\left(^{\circ}\right)$ \\
\hline 20 & 130 & 0,55 & 18 \\
\hline 50 & 50 & 1,21 & 36 \\
\hline 50 & 200 & 0,77 & 25 \\
\hline 200 & 130 & 0,69 & 22 \\
\hline
\end{tabular}


Interpretando-se os resultados dos ensaios de cisalhamento direto executados na argila, segundo Fredlund et al. (1978), verifica-se que o valor de $\phi^{b}$ obtido para a sucção de $50 \mathrm{kPa}, 36^{\circ}$, é maior que o valor obtido para as sucções entre 130 e 200 $\mathrm{kPa}$, cerca de $22^{\circ}$, variando entre 18 e $25^{\circ}$. Esses resultados estão em concordância com os resultados obtidos por Abramento e Pinto (1993) que verificaram que a relação entre o aumento da resistência ao cisalhamento do colúvio não saturado estudado e o incremento da sucção não foi linear para toda a faixa de sucções, conforme proposta apresentada por Fredlund et ali (1978). Aqueles autores verificaram que para baixas sucções, entre 0 e $60 \mathrm{kPa}$, a variação do intercepto de coesão total com a sucção ficou bem representada por uma equação exponencial.

Observou-se que o valor de $\phi^{b}\left(36^{\circ}\right)$ obtido para sucções menores que $60 \mathrm{kPa}$ é maior que o valor de $\phi^{\prime}\left(31^{\circ}\right)$, resultado já descrito na literatura porém pouco comum. Outras análises sobre a resistência ao cisalhamento da argila serão apresentadas em conjunto com os dados obtidos em ensaios de compressão simples.

\section{Ensaios de compressão simples}

Foram realizados ensaios de compressão simples com amostras indeformadas do aterro argiloso, retiradas do campo experimental, com sucções iniciais de 25, 50, 100 e $400 \mathrm{kPa}$. Essas sucções foram obtidas deixando-se amostras moldadas secando ao ar, ou acrescentando-se água por meio de aspersão.

Verificou-se que quanto maior a sucção inicial das amostras maior a tensão desviadora na ruptura, e maior a deformação axial específica na ruptura, conforme mostra a Figura 4.32. O resultado pode ser explicado considerando que maiores sucções resultam em maior coesão aparente do solo, e em maior resistência ao cisalhamento.

Os ensaios realizados com sucção inicial de 25 e $50 \mathrm{kPa}$ resultaram em crescimento da sucção ao longo do ensaio de compressão simples, e resultaram em sucções na ruptura de 37 e $81 \mathrm{kPa}$, respectivamente, conforme pode ser visto na Figura 4.33. 


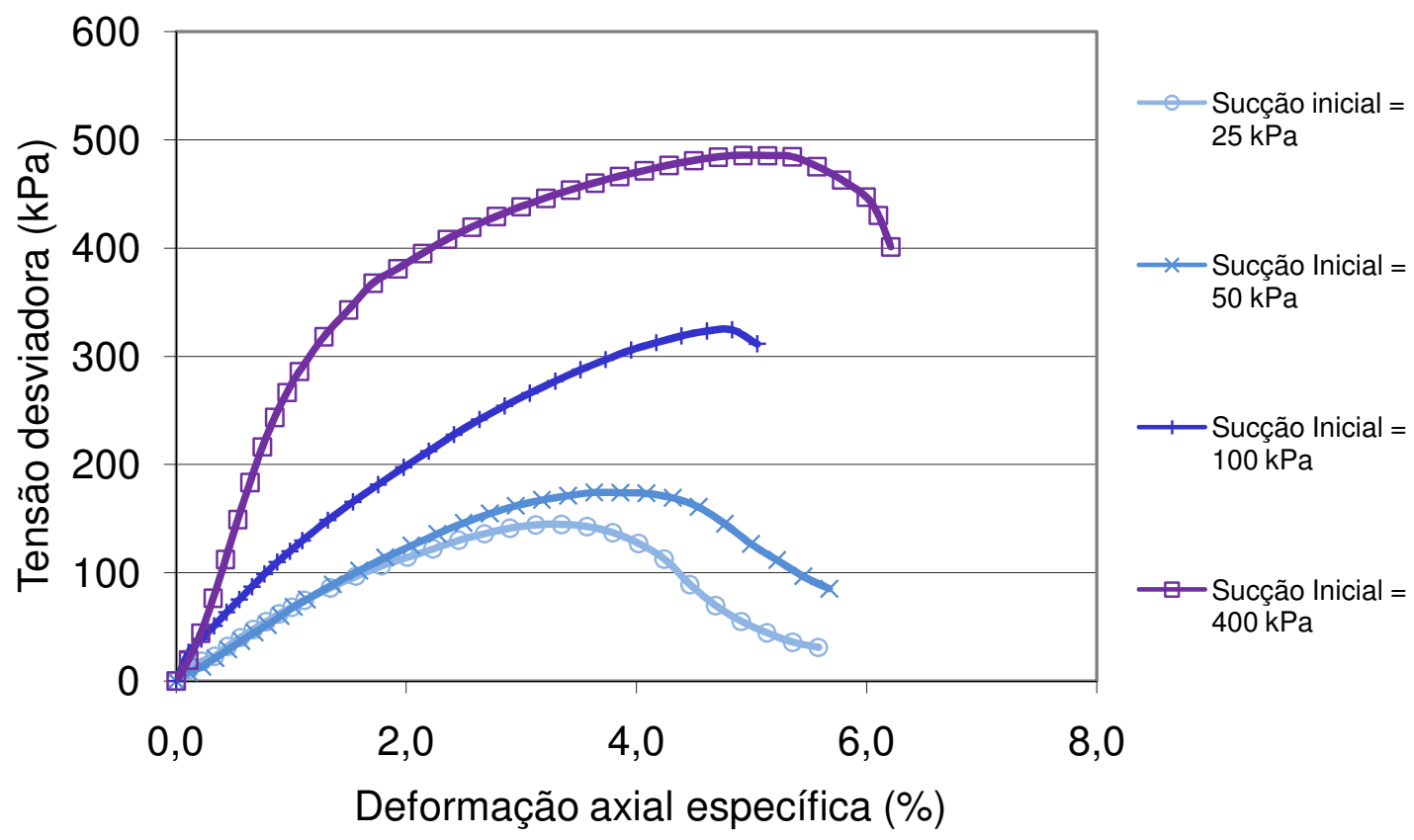

Figura 4.32: Tensão desviadora em função da deformação axial específica para os ensaios de compressão simples realizados no aterro argiloso, realizados com várias sucções iniciais

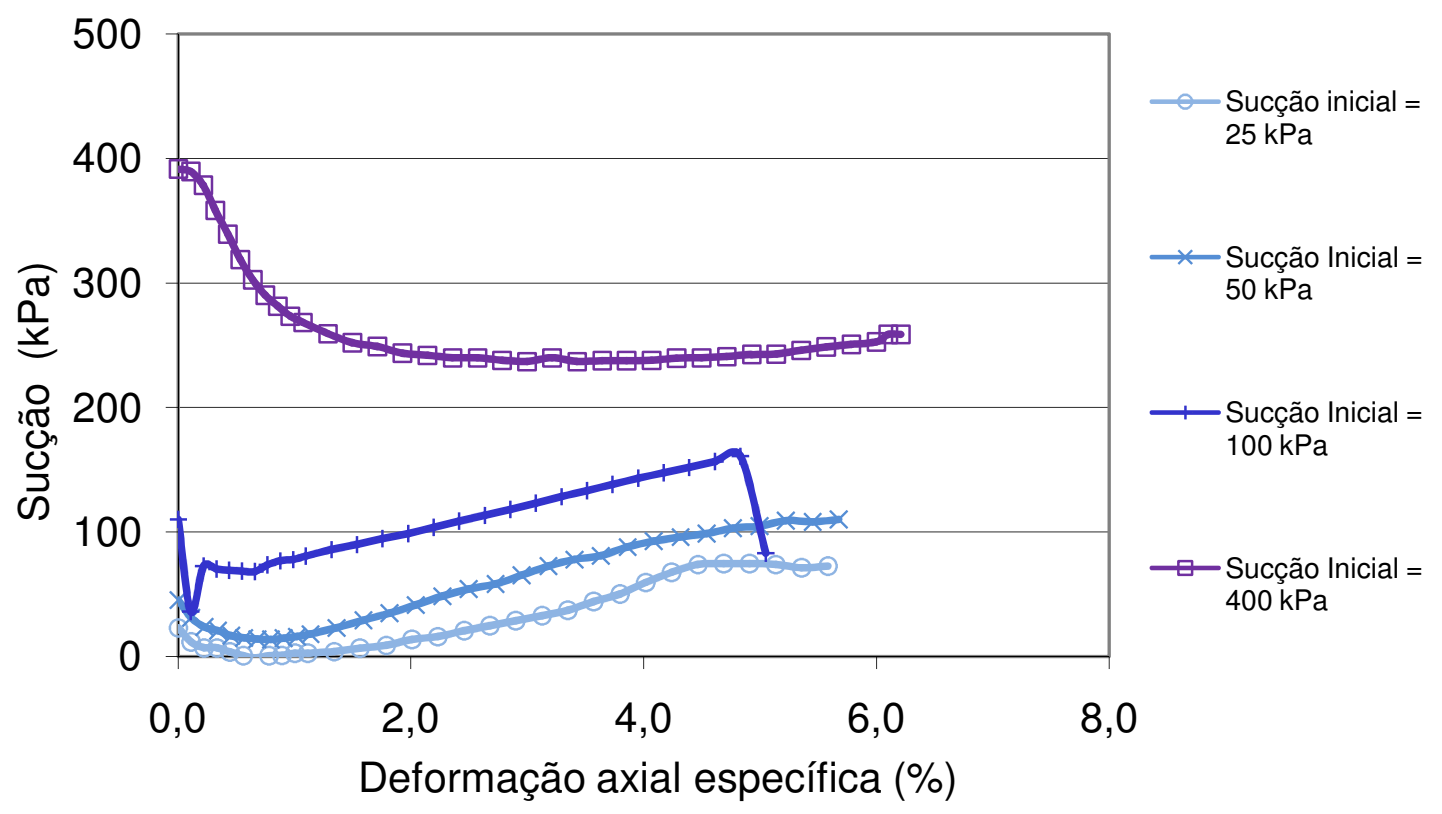

Figura 4.33: Sucção em função da deformação axial específica para os ensaios de compressão simples realizados no aterro argiloso, realizados com várias sucções iniciais 
O ensaio realizado com sucção inicial de $100 \mathrm{kPa}$ apresentou crescimento da sucção ao longo do ensaio de compressão simples, ruptura com sucção igual a 161 $\mathrm{kPa}$, e redução da sucção após a ruptura. O ensaio realizado com sucção inicial de $400 \mathrm{kPa}$ apresentou redução da sucção ao longo do ensaio de compressão simples, ruptura do corpo de prova com sucção igual a $242 \mathrm{kPa}$, e crescimento da sucção após a ruptura.

Na Figura 4.34 é apresentada uma "envoltória" da tensão desviadora em função da sucção na ruptura, para a argila ensaiada.

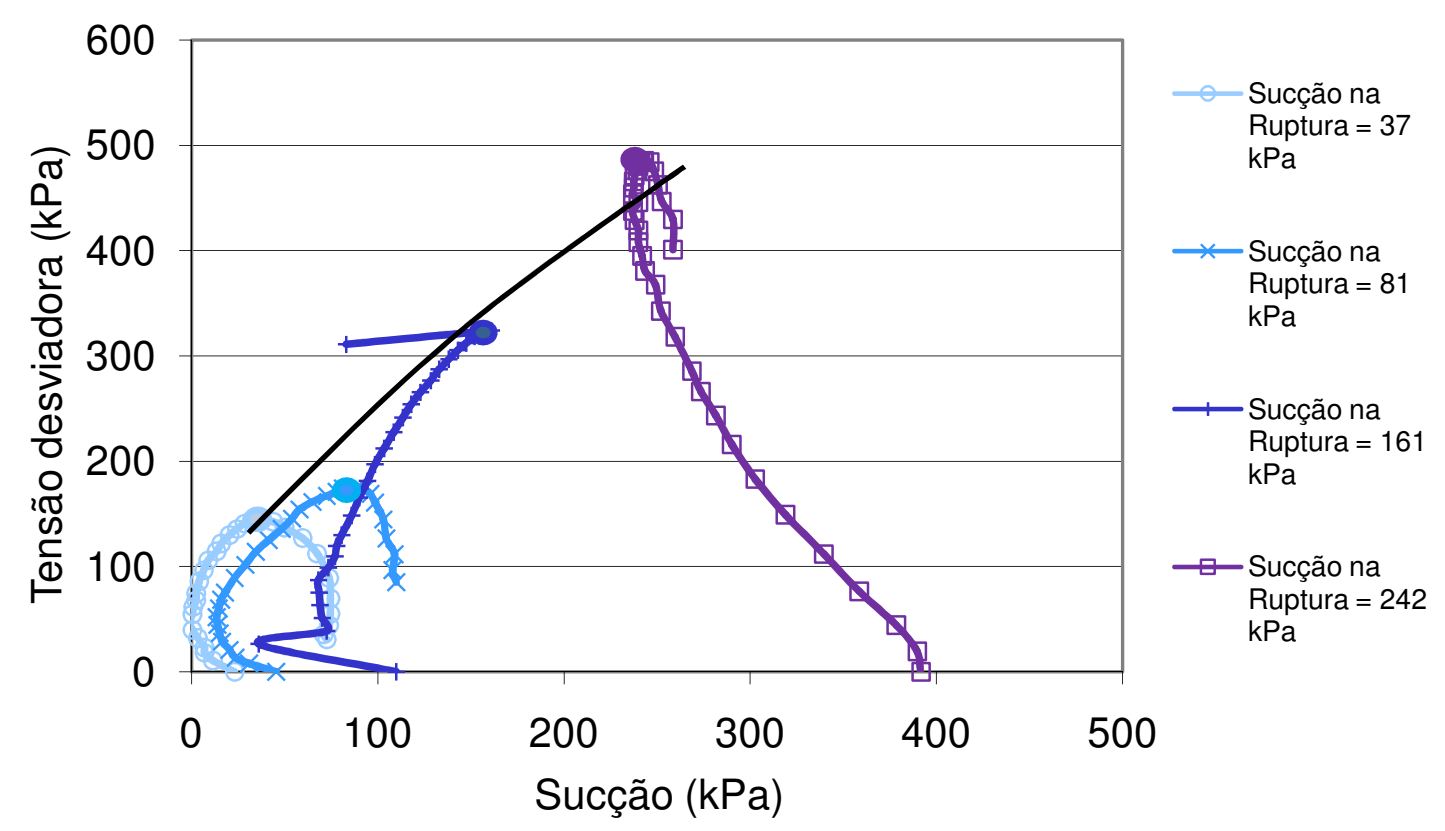

Figura 4.34: Tensão desviadora em função da sucção do corpo de prova para os ensaios de compressão simples realizados no aterro argiloso

Os ensaios de compressão simples no aterro argiloso apresentaram os seguintes resultados para a tensão de cisalhamento, de acordo com a sucção, conforme podem ser vistos na Tabela 4.6. 
Tabela 4.6: Resistência à compressão simples do aterro argiloso, em função das condições de ensaio

\begin{tabular}{|c|c|c|c|}
\hline $\begin{array}{c}\text { Sucção } \\
\text { Inicial }\end{array}$ & $\begin{array}{c}\text { Sucção na } \\
\text { Ruptura }\end{array}$ & $\begin{array}{c}\text { Tensão Normal } \\
\text { no Plano de } \\
\text { Ruptura }\end{array}$ & $\begin{array}{c}\text { Tensão de } \\
\text { Cisalhamento } \\
\text { no Plano de } \\
\text { Ruptura }\end{array}$ \\
\hline$(\mathrm{kPa})$ & $(\mathrm{kPa})$ & $(\mathrm{kPa})$ & $(\mathrm{kPa})$ \\
\hline 25 & 37 & 31 & 63 \\
\hline 50 & 81 & 37 & 75 \\
\hline 100 & 161 & 69 & 140 \\
\hline 400 & 242 & 104 & 209 \\
\hline
\end{tabular}

São apresentadas na Figura 4.35 as envoltórias de resistência ao cisalhamento da argila não saturada, para sucções na ruptura iguais 37, 81, 161 e $242 \mathrm{kPa}$, e para a argila inundada, obtida em ensaios de cisalhamento direto apresentados anteriormente.

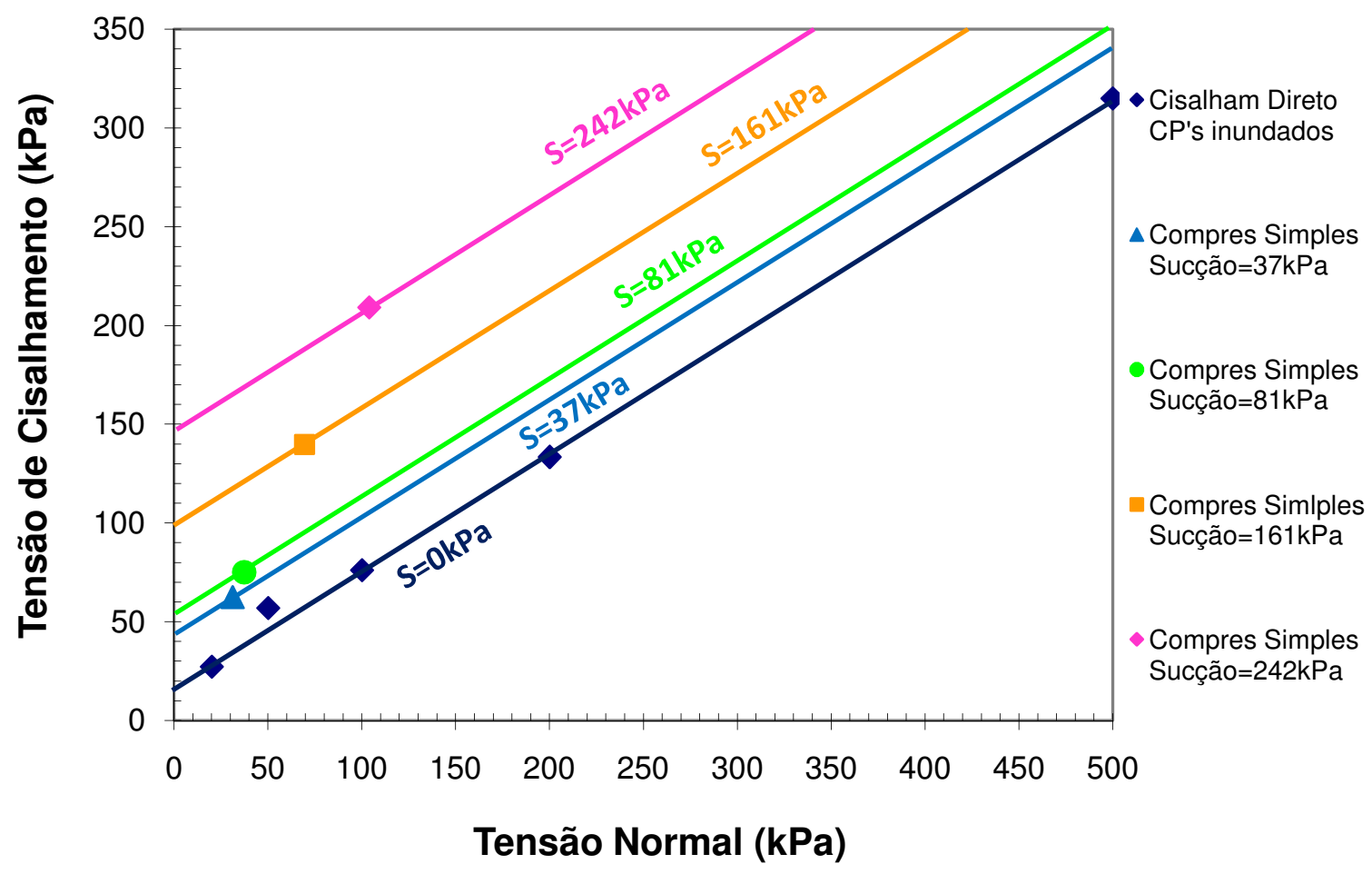

Figura 4.35: Envoltórias de resistência da argila, para os ensaios de compressão simples 
Os parâmetros $\chi$ e $\phi^{b}$ obtidos nos ensaios de compressão simples apresentados na Tabela 4.7, são pouco maiores que os obtidos nos ensaios de cisalhamento direto apresentados na Tabela 4.3. E, da mesma forma que os resultados dos ensaios de cisalhamento direto, os ensaios de compressão simples indicaram valores de $\chi$ e $\phi^{b}$ maiores, 1,30 e $38^{\circ}$, para sucções menores, $37 \mathrm{kPa}$; e em média menores, 0,84 e $27^{\circ}$, para sucções maiores, entre 81 e $242 \mathrm{kPa}$.

Tabela 4.7: Parâmetros de Bishop (1959) e por Fredlund et al. (1978) para ensaios de compressão simples

\begin{tabular}{|c|c|c|}
\hline Sucção & $\chi$ & $\boldsymbol{\phi}^{\boldsymbol{b}}$ \\
\hline$(\mathrm{kPa})$ & - & $\left(^{\circ}\right)$ \\
\hline 37 & 1,30 & 38 \\
\hline 81 & 0,77 & 25 \\
\hline 161 & 0,86 & 27 \\
\hline 242 & 0,91 & 29 \\
\hline
\end{tabular}

Os resultados dos ensaios de compressão simples não saturados podem ser visualizados, juntamente com os resultados dos ensaios de cisalhamento direto não saturados, no gráfico da Figura 4.36. Os resultados indicaram que a coesão aumenta com a sucção, até o limite dos valores ensaiados, e que há coerência entre os resultados obtidos nos dois tipos de ensaios realizados. Os valores de $\phi^{b}$ obtidos nos ensaios de cisalhamento direto e compressão simples para sucções menores ou iguais a $50 \mathrm{kPa}, 36^{\circ}$ e $38^{\circ}$, respectivamente, são coerentes entre si e maiores que os valores médios obtidos nos dois tipos de ensaio para sucções maiores que $80 \mathrm{kPa} e$ menores que $242 \mathrm{kPa}, 22^{\circ}$ e $27^{\circ}$, respectivamente. 


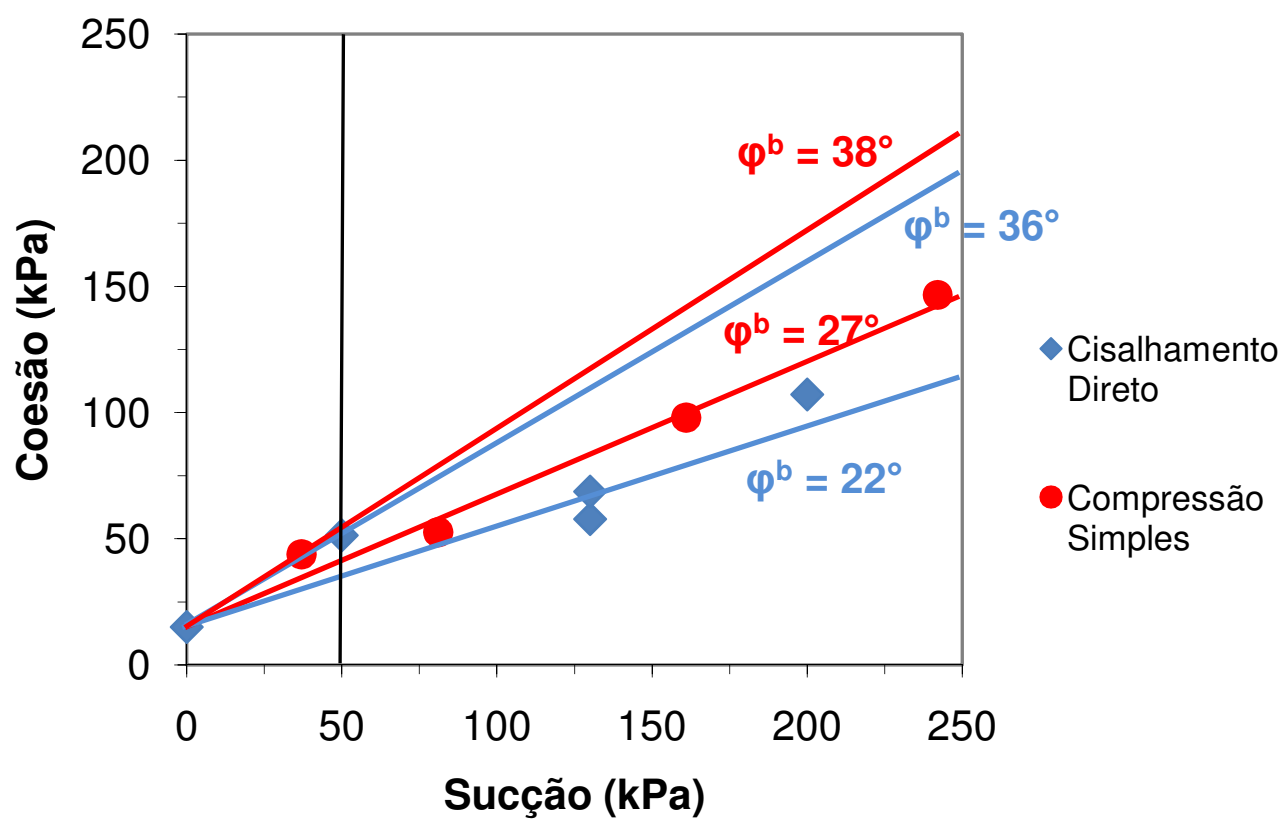

Figura 4.36: Interpretação dos ensaios de compressão simples e cisalhamento direto realizados no aterro não saturado

\section{Resistência ao cisalhamento adotada para a argila}

Considerando que a resistência ao cisalhamento a ser adotada para a argila neste trabalho será utilizada para cálculos de estabilidade do talude experimental em que foram registradas sucções variando entre 0 e $60 \mathrm{kPa}$ durante o período de monitoramento, adotar-se-á $36^{\circ}$ para o valor de $\phi^{b}$ e 1,21 para o valor de $\chi$.

Os parâmetros efetivos de resistência obtidos nos ensaios de cisalhamento direto inundados foram $15 \mathrm{kPa}$ para a coesão e $31^{\circ}$ para o ângulo de atrito. As equações adotadas segundo os modelos de Bishop (1959) e por Fredlund et al. (1978) são, respectivamente:

$$
\begin{aligned}
& s=15+\left[\left(\sigma-u_{a}\right)+1,21\left(u_{a}-u_{w}\right)\right] \operatorname{tg} 31^{\circ} \\
& s=15+\left(\sigma-u_{a}\right) \operatorname{tg} 31^{\circ}+\left(u_{a}-u_{w}\right) \operatorname{tg} 36^{\circ}
\end{aligned}
$$




\section{Ajuste dos parâmetros de resistência}

Foram realizados ajustes hiperbólicos dos parâmetros de resistência da argila não saturada de acordo com os modelos propostos por Futai (2004) e Vilar (2006), conforme pode ser visto na Figura 4.37. As equações dos ajustes são apresentadas no corpo dessa figura.

Foram feitos dois ajustes para cada modelo de estimativa da resistência com o objetivo de se obter uma faixa onde poderia estar situada a coesão da argila para sucções maiores que $250 \mathrm{kPa}$. As faixas obtidas com os modelos de Futai (2004) e Vilar (2006) indicam tendências de variação da coesão diversas. A coesão obtida para o corpo de prova seco ao ar no ensaio de cisalhamento direto (70 kPa), indicada na Figura 4.37, é menor do que as estimativas obtidas por ambos os modelos utilizados, também é menor do que a coesão obtida no ensaio com sucção igual a $200 \mathrm{kPa}(107 \mathrm{kPa})$, indicando queda de resistência conforme descrito anteriormente, e portanto deve ser desconsiderado.

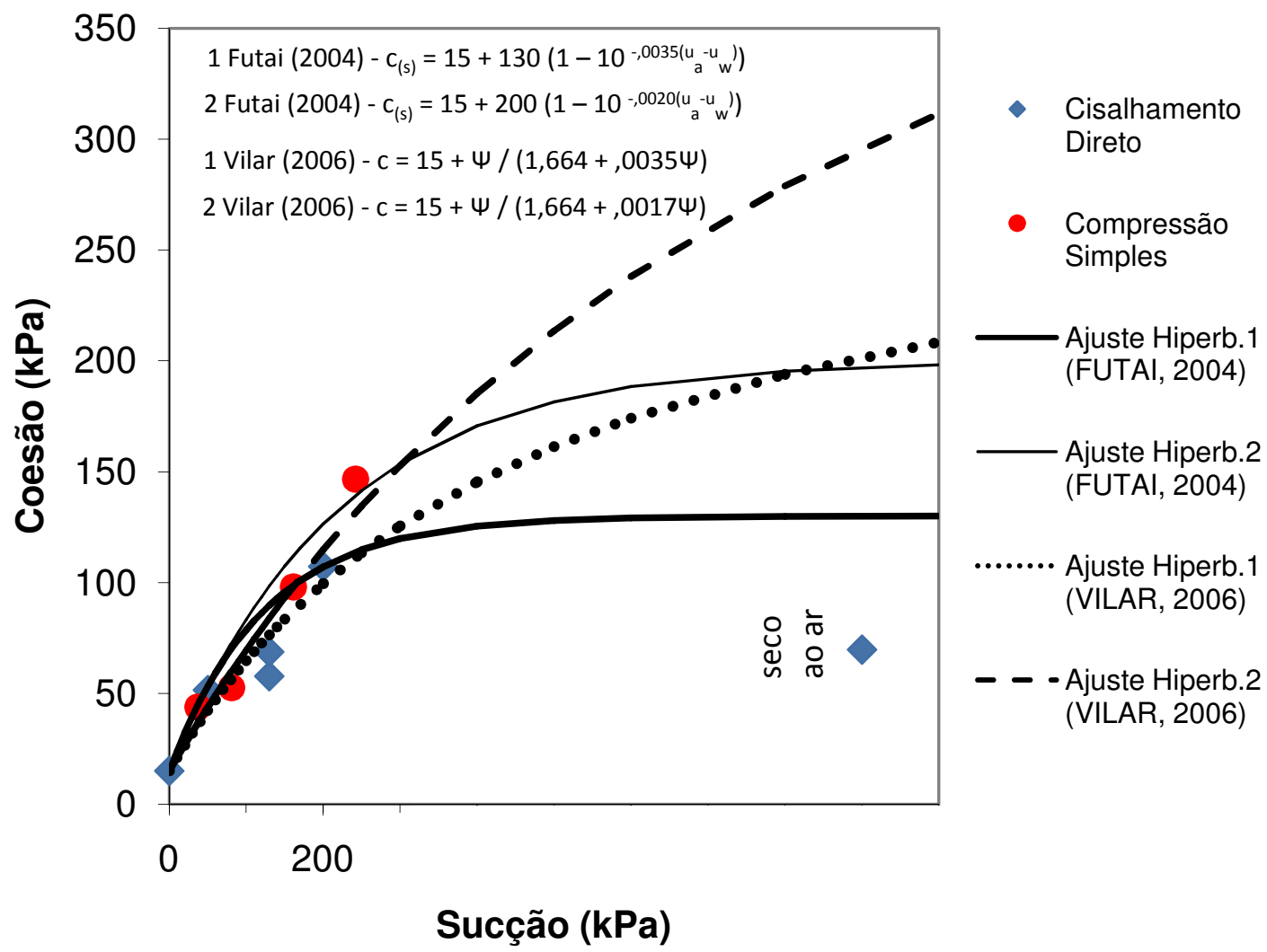

Figura 4.37: Ajustes do intercepto de coesão com ângulo de atrito constante, para os ensaios de cisalhamento direto e compressão simples não saturados, na argila 
Os ajustes apresentados fornecem estimativas da resistência ao cisalhamento da argila não saturada que devem ser consideradas válidas apenas na faixa de sucções em que foram realizados os ensaios, 0 a $240 \mathrm{kPa}$.

\subsubsection{Solo residual siltoso}

Foram realizados ensaios de cisalhamento direto e compressão simples com amostras do solo residual siltoso nas condições inundada e não saturada, considerando a mesma programação de ensaios que foi realizada com a argila exceto os valores de sucção das amostras. Apresentam-se a seguir os resultados obtidos e análises desses resultados:

\section{Ensaios de cisalhamento direto}

Os resultados dos ensaios de cisalhamento direto no silte inundado indicaram que maiores tensões normais de ensaio resultaram, de uma maneira aproximada, em maiores deslocamentos verticais durante o cisalhamento, conforme pode ser visto na Figura 4.38. Resultado, esse, similar ao obtido para a argila inundada, apresentado na Figura 4.27.

O ensaio inundado com tensão normal igual a $500 \mathrm{kPa}$ apresentou redução de volume do corpo de prova de cerca de $2 \%$. Os ensaios realizados com tensões normais iguais a 100 e $200 \mathrm{kPa}$ apresentaram variação de volume, menor, de cerca de $0,6 \%$. Os demais ensaios, em que foram aplicadas tensões normais iguais a $20 \mathrm{e}$ $50 \mathrm{kPa}$ apresentaram dilatância, com aumento de volume do corpo de prova de cerca de 0,3\%. Supõe-se que o silte ensaiado apresentava-se sobre-adensado em relação à tensão normal aplicada nos ensaios que indicaram aumento de volume $\mathrm{e}$ possivelmente nos ensaios que apresentaram pequenas reduções de volume, conforme ocorre em ensaios triaxiais.

No gráfico da Figura 4.39 é apresentada a variação da tensão cisalhante em função do deslocamento horizontal durante os ensaios de cisalhamento direto realizados com o silte inundado. As tensões cisalhantes máximas foram tanto maiores quanto 
maiores as tensões normais aplicadas ao corpo de prova, da mesma maneira em que ocorreu nos ensaios com a argila inundada.

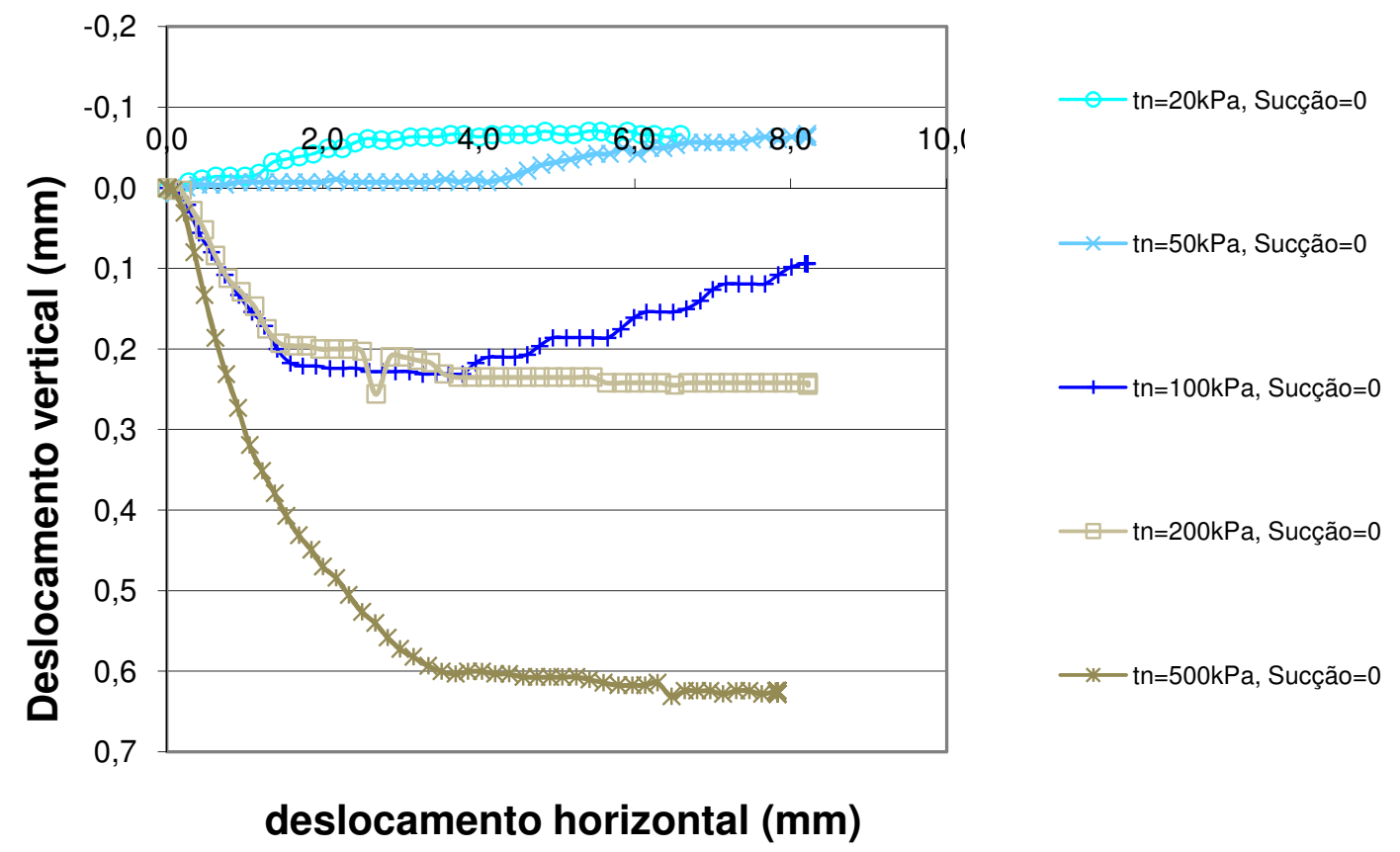

Figura 4.38: Gráfico do deslocamento vertical em função do deslocamento horizontal, no ensaio com o silte inundado, de acordo com a tensão normal aplicada

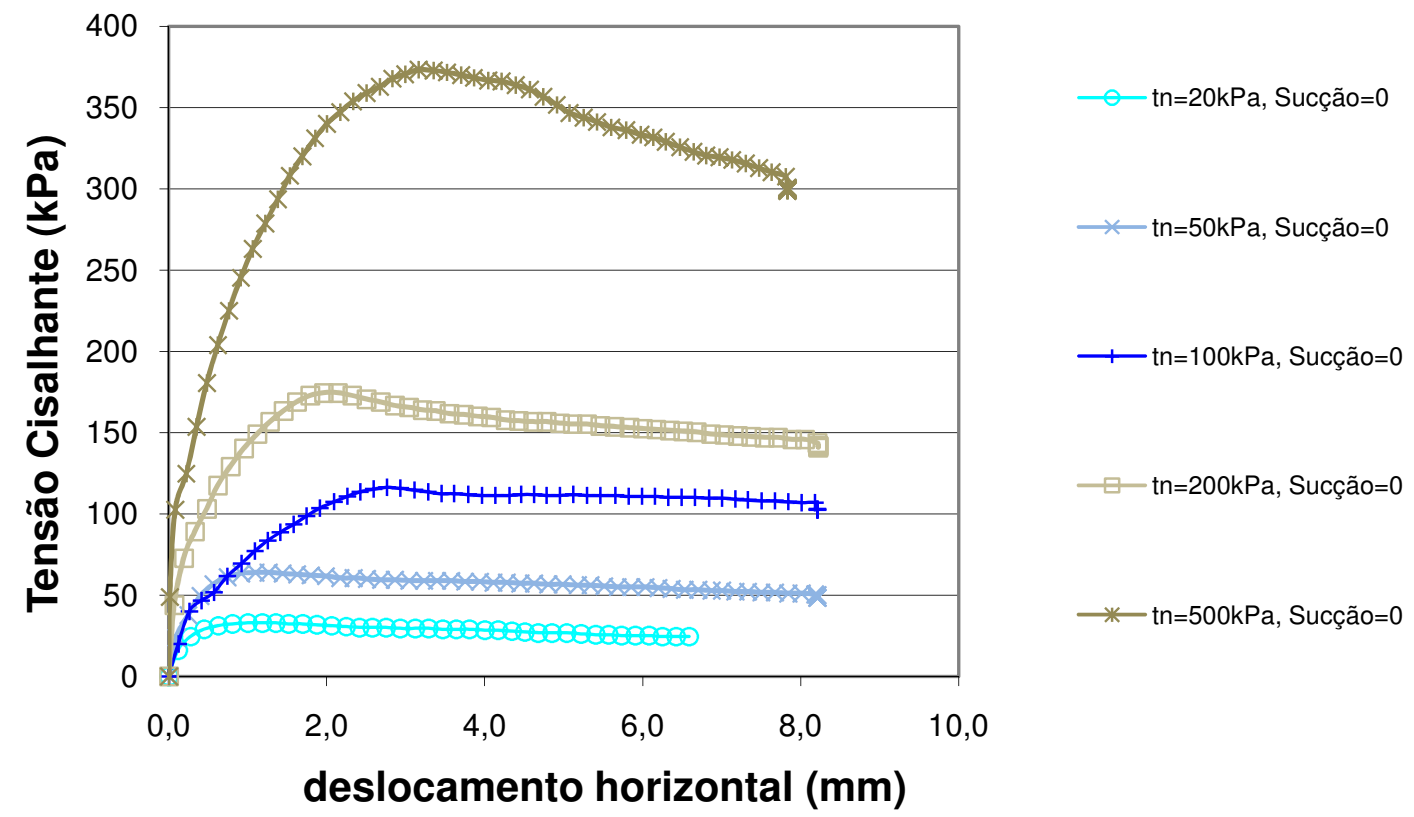

Figura 4.39: Gráfico da tensão cisalhante em função do deslocamento horizontal, no ensaio com o silte inundado, de acordo com a tensão normal aplicada 
Assim como nos ensaios com a argila não saturada (Fig. 4.29) os ensaios com o silte com mesma sucção, $130 \mathrm{kPa}$, indicaram dilatância para o ensaio com tensão normal igual a $20 \mathrm{kPa}$, e comportamento compressivo para o ensaio realizado com tensão normal igual a $200 \mathrm{kPa}$, conforme pode ser visto na Figura 4.40 .

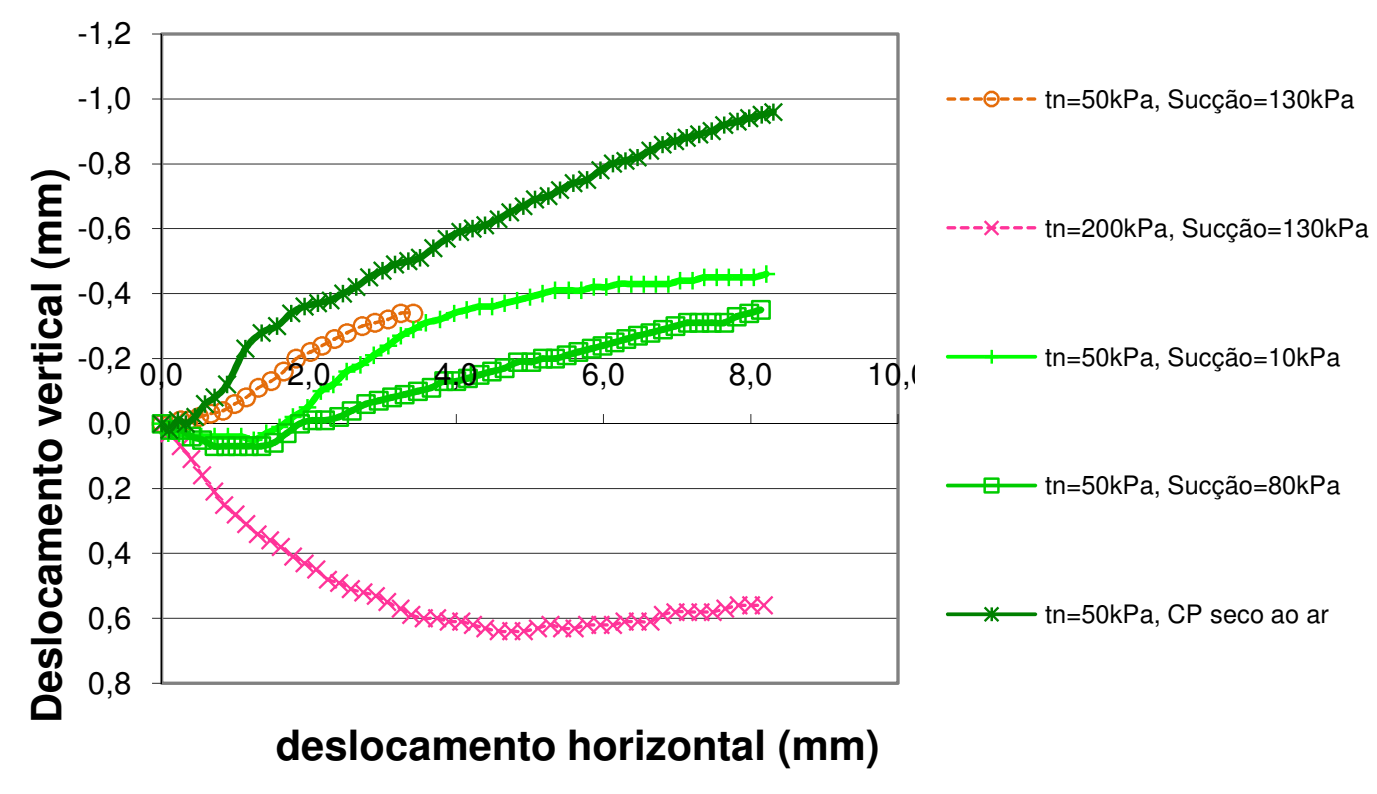

Figura 4.40: Gráfico do deslocamento vertical em função do deslocamento horizontal, no ensaio com o silte não saturado, de acordo com a tensão normal aplicada e com a sucção do corpo de prova ao final do ensaio

Os ensaios não saturados realizados com mesma tensão normal, $50 \mathrm{kPa}$, não apresentaram resultado conclusivo: dilatância decrescente com o aumento da sucção do corpo de prova, de $10 \mathrm{kPa}$ para $80 \mathrm{kPa}$; e dilatância crescente com o aumento da sucção de $80 \mathrm{kPa}$ para seco ao ar. Ao contrário do resultado com a argila, o corpo de prova do silte seco ao ar apresentou aumento da dilatância, e da resistência, em relação ao corpo de prova ensaiado com sucção igual a $80 \mathrm{kPa}$.

Os ensaios realizados com tensão normal igual a $50 \mathrm{kPa}$ e variadas sucções apresentaram resistências residuais iguais, de cerca de $50 \mathrm{kPa}$, conforme pode ser visto na Figura 4.41. As resistências de pico desses ensaios, 61, 76, 105 e $172 \mathrm{kPa}$, realizados com sucções iguais a 10,80 , e $130 \mathrm{kPa}$ e seco ao ar, respectivamente 
foram tanto maiores quanto maiores foram as sucções dos corpos de prova. E os deslocamentos horizontais na ruptura foram decrescentes com o aumento das sucções dos corpos de prova.

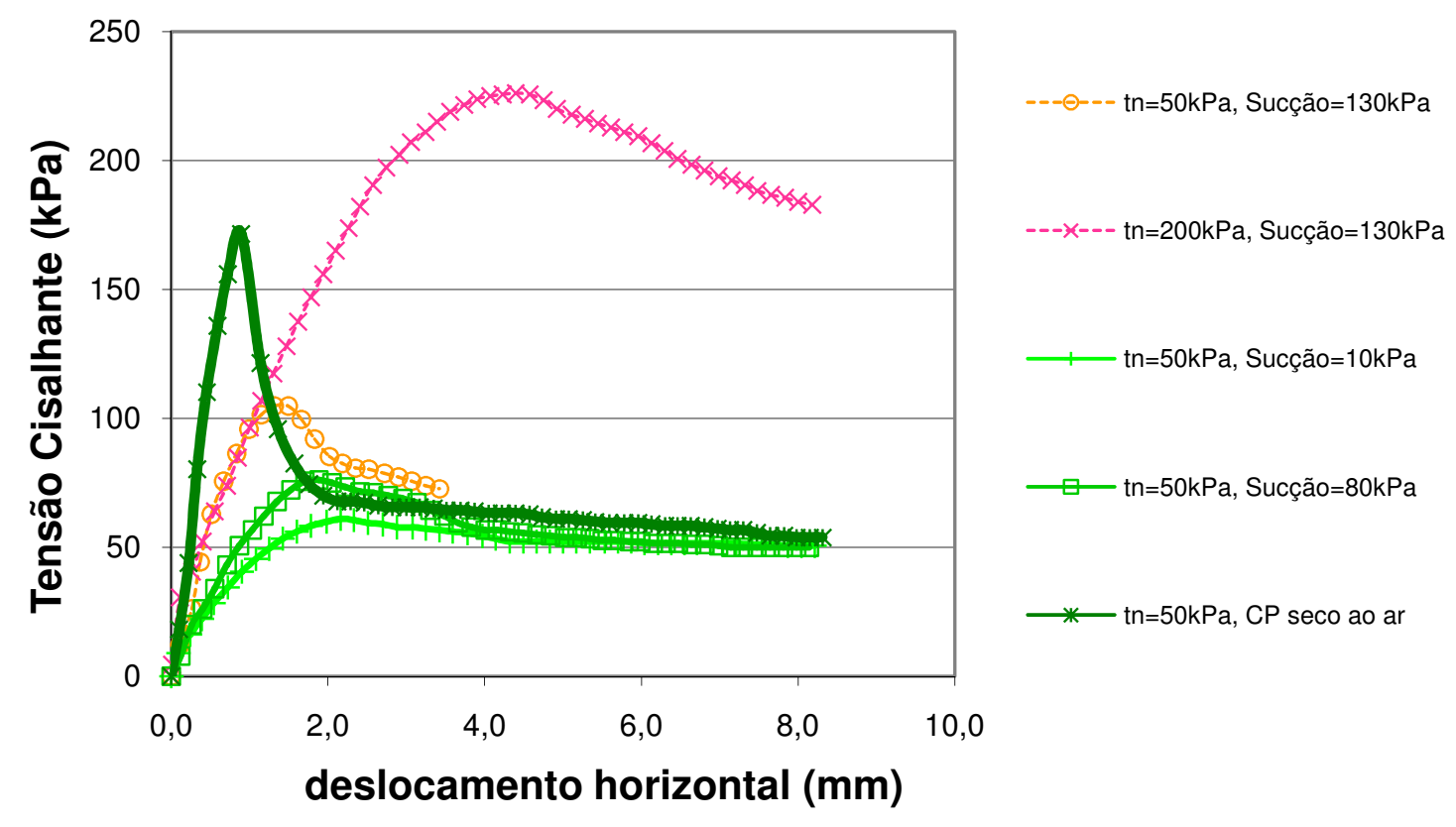

Figura 4.41: Gráfico da tensão cisalhante em função do deslocamento horizontal, no ensaio com o silte não saturado, de acordo com a tensão normal aplicada e com a sucção do corpo de prova ao final do ensaio

Os ensaios de cisalhamento direto com o solo residual siltoso apresentaram os resultados indicados na Tabela 4.8 para a tensão de cisalhamento, de acordo com a tensão normal aplicada e sucção medida após a ruptura. 
Tabela 4.8: Resistência ao cisalhamento do aterro argiloso medida em ensaios de cisalhamento direto inundado e não saturado

\begin{tabular}{|c|c|c|}
\hline $\begin{array}{c}\text { Tensão } \\
\text { Normal }\end{array}$ & $\begin{array}{c}\text { Sucção na } \\
\text { Ruptura }\end{array}$ & $\begin{array}{c}\text { Tensão de } \\
\text { Cisalhamento }\end{array}$ \\
\hline$(\mathrm{kPa})$ & $(\mathrm{kPa})$ & $(\mathrm{kPa})$ \\
\hline 20 & 0 & 33 \\
\hline 50 & 0 & 64 \\
\hline 100 & 0 & 116 \\
\hline 200 & 0 & 175 \\
\hline 500 & 0 & 374 \\
\hline 50 & 130 & 106 \\
\hline 200 & 130 & 226 \\
\hline 50 & 10 & 61 \\
\hline 50 & 80 & 76 \\
\hline 50 & seco ao ar & 172 \\
\hline
\end{tabular}

A envoltória de resistência obtida para o silte inundado resultou nos seguintes parâmetros geotécnicos: ângulo de atrito efetivo de $35^{\circ}$ e coesão efetiva de $19 \mathrm{kPa}$. São apresentadas na Figura 4.37 as envoltórias de resistência para o solo inundado e para sucções iguais 80 e $130 \mathrm{kPa}$, além da envoltória para a amostra seca ao ar.

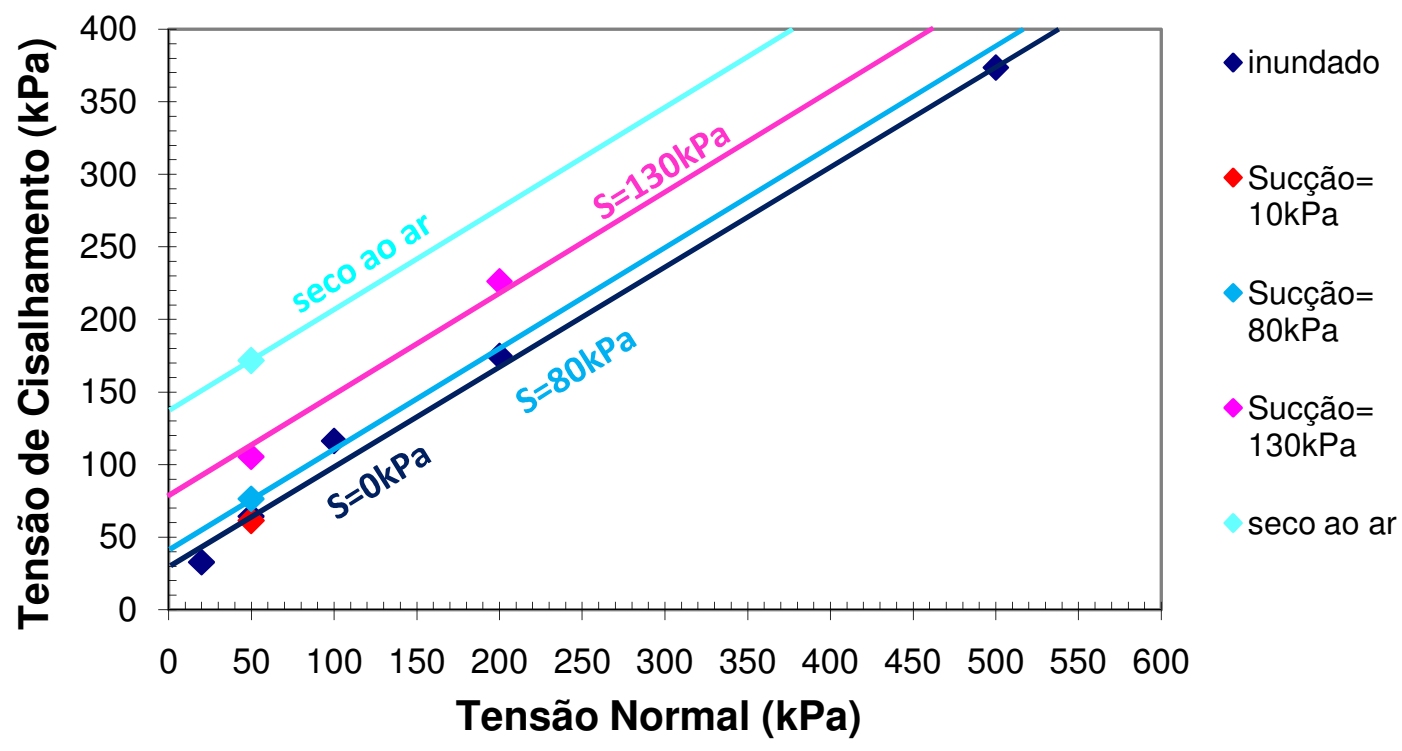

Figura 4.42: Envoltórias de resistência do silte, para os ensaios de cisalhamento direto 
Analisando-se os resultados obtidos segundo as equações propostas por Bishop (1959) e por Fredlund et al. (1978) para solos não saturados obteve-se os parâmetro $\chi$ e $\phi^{\mathrm{b}}$ apresentados na Tabela 4.9. Esses valores foram obtidos tomando-se por base os valores de coesão e ângulo de atrito efetivos obtidos nos ensaios de cisalhamento direto com corpos de prova inundados.

Tabela 4.9: Parâmetros de resistência ao cisalhamento do aterro argiloso não saturado obtidos em ensaios de cisalhamento direto não saturado

\begin{tabular}{|c|c|c|c|}
\hline $\begin{array}{c}\text { Tensão } \\
\text { Normal }\end{array}$ & Sucção & $\chi$ & $\phi^{\mathrm{b}}$ \\
\hline$(\mathrm{kPa})$ & $(\mathrm{kPa})$ & - & $\left(^{\circ}\right)$ \\
\hline 50 & 130 & 0,57 & 22 \\
\hline 50 & 10 & 1,00 & 35 \\
\hline 50 & 80 & 0,39 & 15 \\
\hline 200 & 130 & 0,74 & 27 \\
\hline
\end{tabular}

Interpretando-se os resultados dos ensaios de cisalhamento direto executados no silte, segundo Fredlund et al. (1978), verifica-se que o valor de $\phi^{\mathrm{b}}$ obtido para a sucção de $10 \mathrm{kPa}, 35^{\circ}$, é maior que os obtidos para sucções entre 130 e $200 \mathrm{kPa}$, cerca de $21^{\circ}$, variando entre 15 e $27^{\circ}$. Esses resultados estão em concordância com os resultados obtidos por Abramento e Pinto (1993), conforme observado anteriormente.

O valor de $\phi^{\mathrm{b}}$ obtido para sucção de $10 \mathrm{kPa}$ é igual ao valor obtido para $\phi^{\prime}, 35^{\circ}$, e o valor médio de $\phi^{\mathrm{b}}$ para sucções entre 130 e $200 \mathrm{kPa}, 21^{\circ}$, é menor que o valor de $\phi^{\prime}$. Outras análises sobre a resistência ao cisalhamento do silte serão apresentadas em conjunto com os dados obtidos em ensaios de compressão simples.

\section{Ensaios de compressão simples}

Foram realizados ensaios de compressão simples com amostras indeformadas do solo residual siltoso, retiradas do campo experimental, com sucções iniciais de 25 , 
50,100 e $450 \mathrm{kPa}$. Essas sucções foram obtidas deixando-se amostras moldadas secando ar ao ar, ou acrescentando-se água por meio de aspersão.

Verificou-se que quanto maior a sucção inicial das amostras maior a tensão desviadora na ruptura, e maior a deformação axial específica na ruptura, exceto para a amostra com sucção inicial de $400 \mathrm{kPa}$, conforme mostra a Figura 4.43.

Os quatro ensaios de compressão simples realizados resultaram em pequena variação da sucção ao longo do ensaio, isso é, de 25 para $27 \mathrm{kPa}$ para o primeiro ensaio, de 50 para $48 \mathrm{kPa}$ para o segundo ensaio, de 100 para $99 \mathrm{kPa}$ para o terceiro,e de 450 para 457 para o quarto ensaio, conforme pode ser visto na Figura 4.44 .

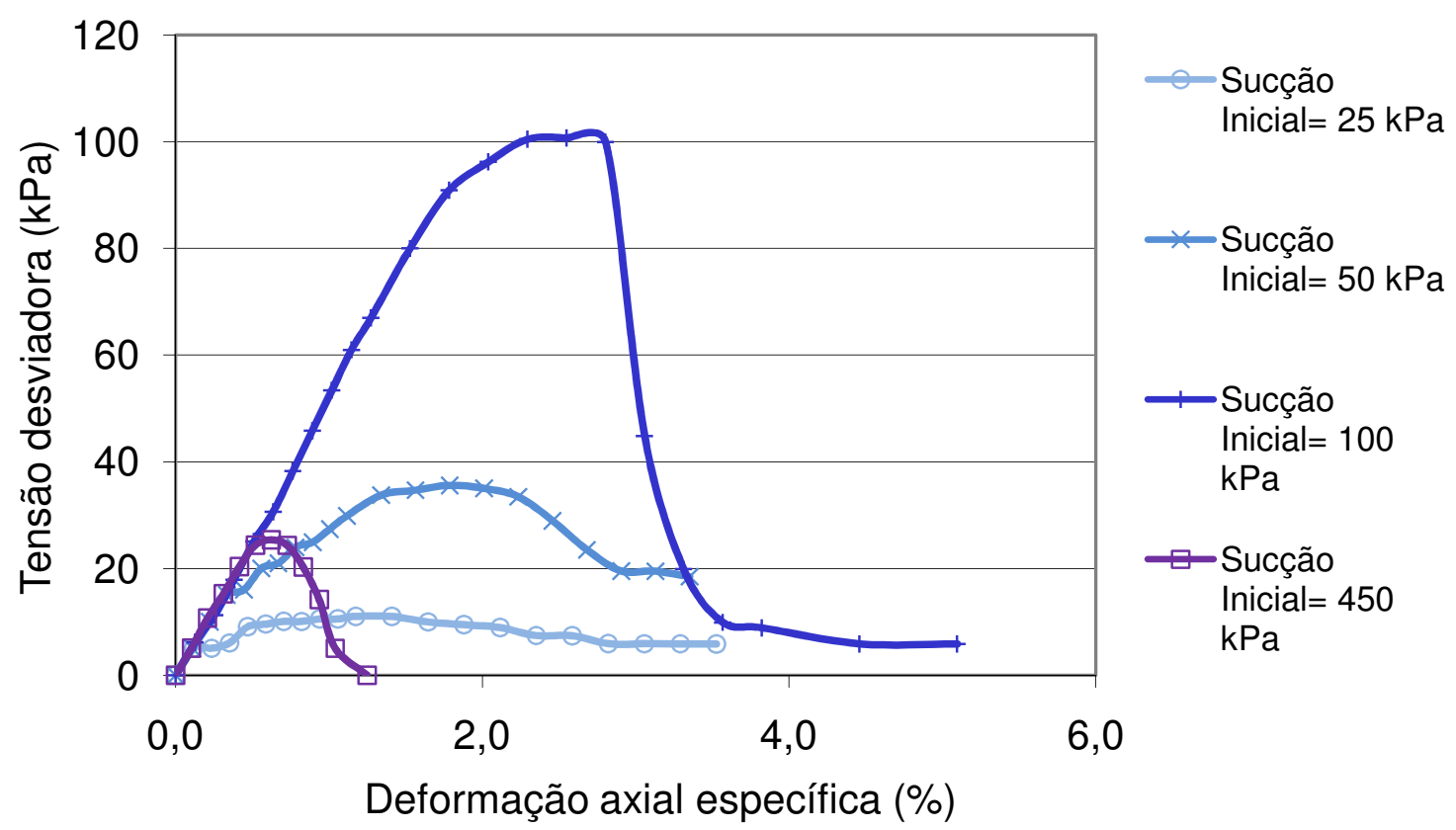

Figura 4.43: Tensão desviadora em função da deformação axial específica para os ensaios de compressão simples realizados no solo residual siltoso, realizados com variadas sucções iniciais 


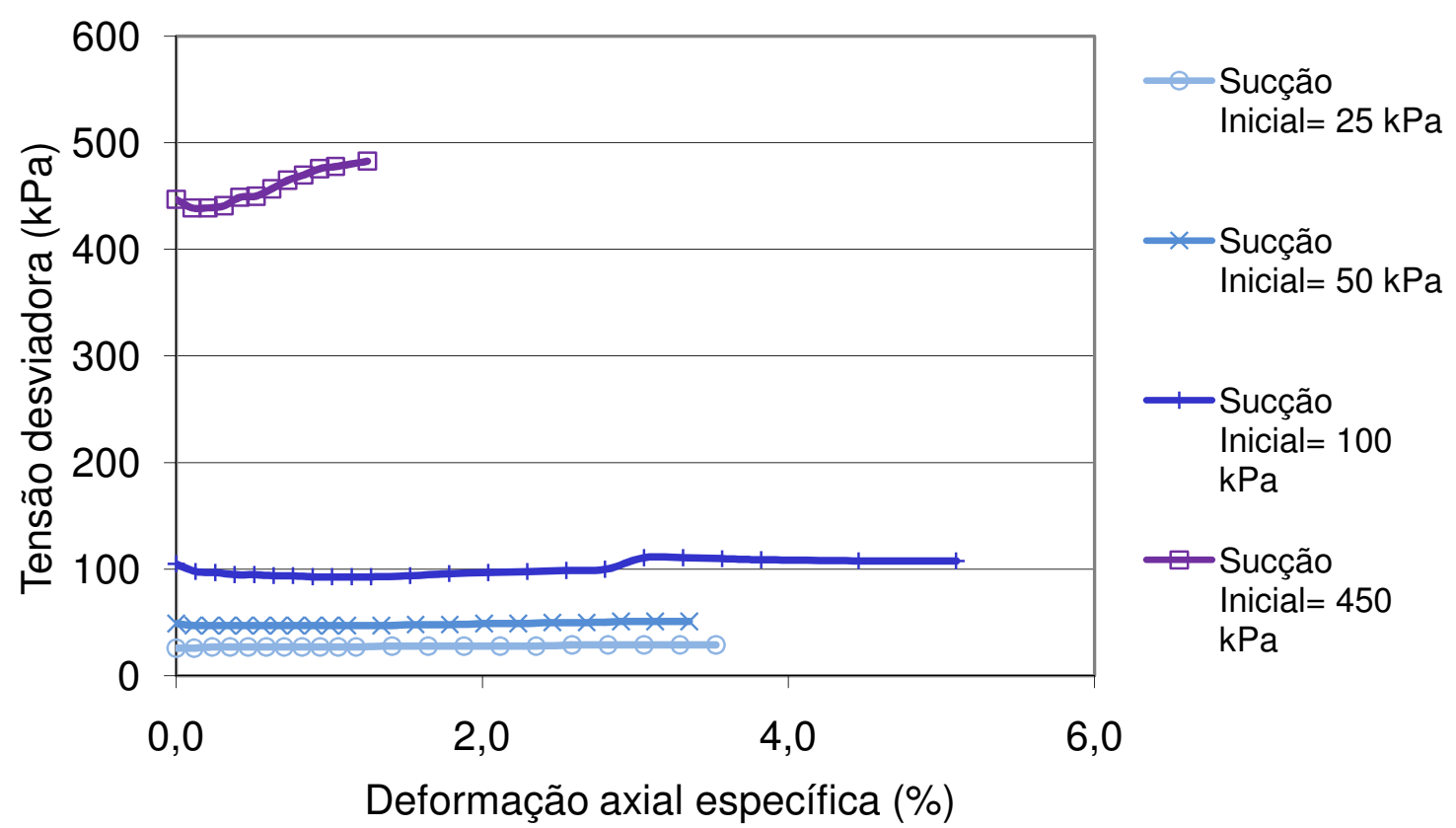

Figura 4.44: Sucção em função da deformação axial específica para os ensaios de compressão simples realizados no solo residual siltoso, realizados com variadas sucções iniciais

Na Figura 4.45 é apresentada uma "envoltória" da tensão desviadora em função da sucção na ruptura, para o silte ensaiado.

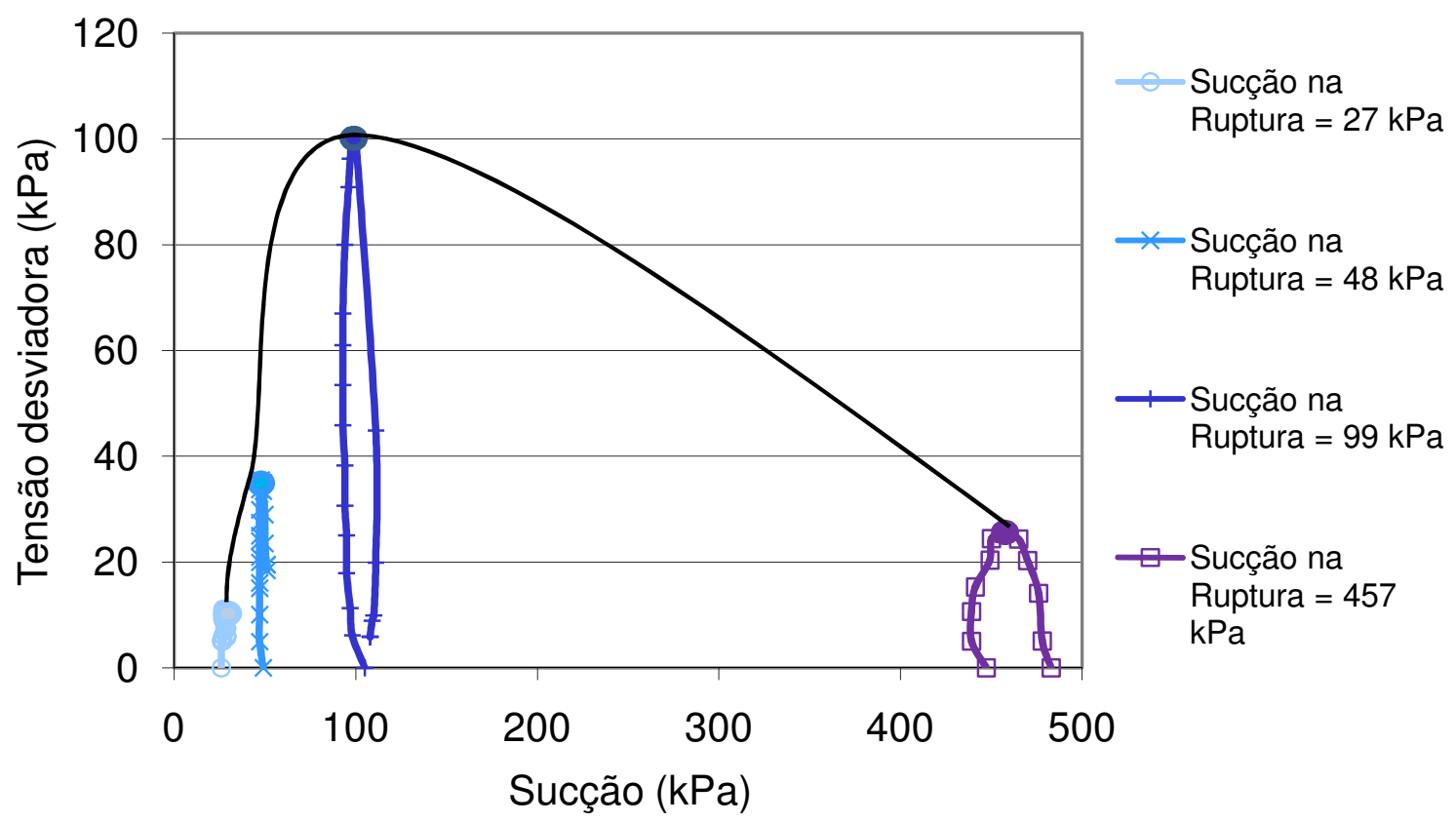

Figura 4.45: Tensão desviadora em função da sucção do corpo de prova para os ensaios de compressão simples realizados no solo residual siltoso 
Os ensaios de compressão simples no solo siltoso apresentaram os seguintes resultados para a resistência ao cisalhamento na ruptura (Tabela 4.10):

Tabela 4.10: Resistência à compressão simples do silte, em função das condições de ensaio

\begin{tabular}{|c|c|c|c|}
\hline $\begin{array}{c}\text { Sucção } \\
\text { Inicial }\end{array}$ & $\begin{array}{c}\text { Sucção na } \\
\text { Ruptura }\end{array}$ & $\begin{array}{c}\text { Tensão Normal } \\
\text { no Plano de } \\
\text { Ruptura }\end{array}$ & $\begin{array}{c}\text { Tensão de } \\
\text { Cisalhamento } \\
\text { no Plano de } \\
\text { Ruptura }\end{array}$ \\
\hline$(\mathrm{kPa})$ & $(\mathrm{kPa})$ & $(\mathrm{kPa})$ & $(\mathrm{kPa})$ \\
\hline 25 & 27 & 2 & 5 \\
\hline 50 & 48 & 7 & 14 \\
\hline 100 & 99 & 19 & 41 \\
\hline 450 & 457 & 5 & 10 \\
\hline
\end{tabular}

São apresentadas na Figura 4.46 as envoltórias de resistência ao cisalhamento do silte não saturado, para sucções na ruptura iguais 27, 48, 99 e $457 \mathrm{kPa}$.

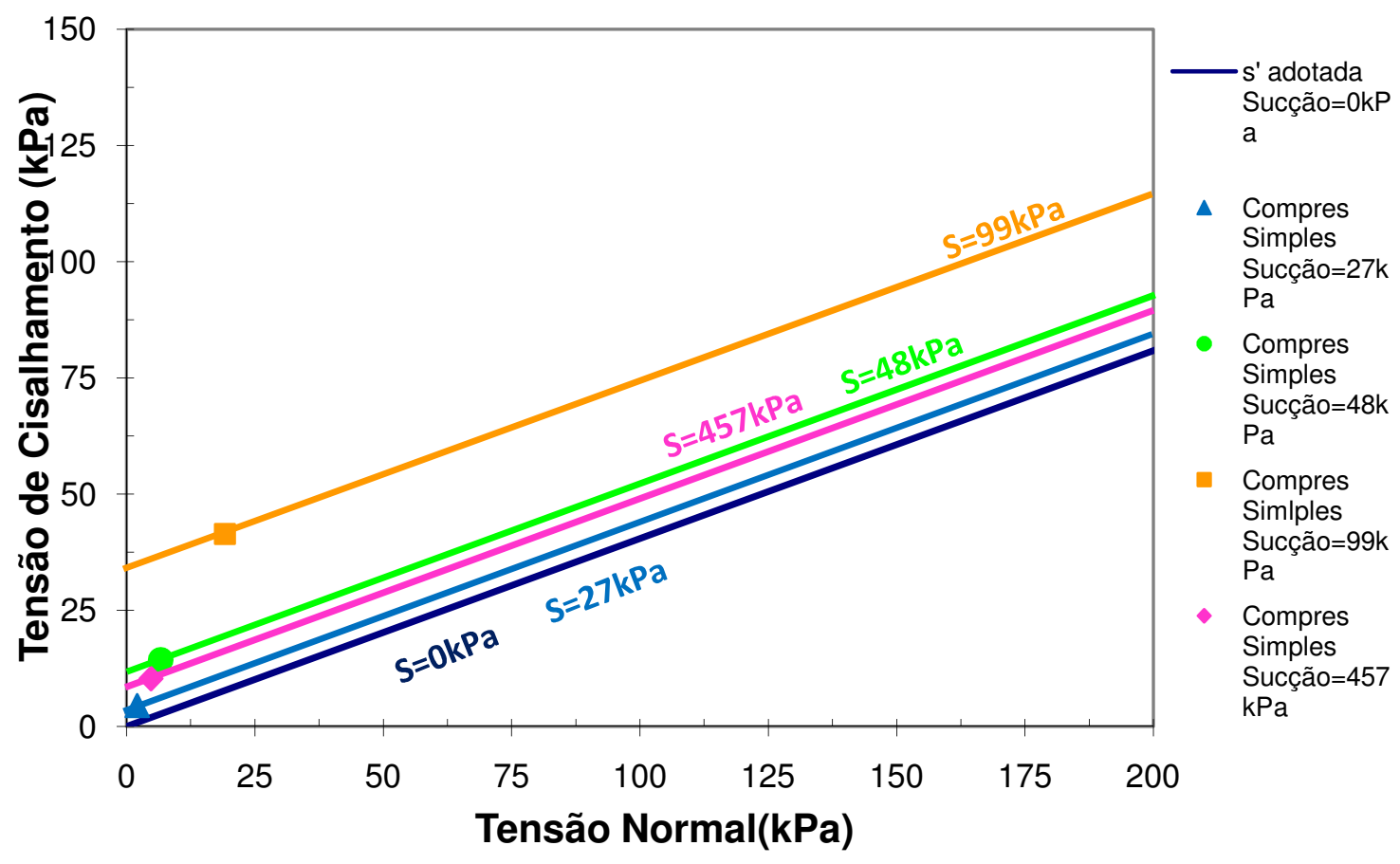

Figura 4.46: Envoltórias de resistência do silte não saturado, para os ensaios de compressão simples, e envoltória do silte saturado adotada 
Destaca-se que a resistência para essa última sucção (457 kPa) é menor que aquela para a sucção de $48 \mathrm{kPa}$ e maior que aquela para sucção de $27 \mathrm{kPa}$, indicando queda da resistência ao cisalhamento do silte para sucções maiores que $457 \mathrm{kPa}$, com tensão de confinamento igual a zero.

Destaca-se que a tensão de confinamento em campo é maior que zero e os resultados obtidos nos ensaios de compressão simples não se aplicam diretamente à situação de campo, em que a tensão de confinamento é crescente com a profundidade. A tensão normal no plano de ruptura para os ensaios de compressão simples (Tabela 4.10) realizados variou entre 2 e $19 \mathrm{kPa}$, valores muito inferiores às tensão normais médias nos planos de ruptura em campo.

As envoltórias de resistência do silte não saturado, apresentadas abaixo, foram traçadas a partir de uma envoltória de resistência saturada estimada, com os seguintes parâmetros geotécnicos efetivos: $c^{\prime}=0$ e $\varphi^{\prime}=22^{\circ}$, definidos com base em valores conservadores indicados na literatura. Não puderam ser utilizados os parâmetros efetivos obtidos nos ensaios de cisalhamento direto inundado, $c^{\prime}=19 \mathrm{kPa}$ e $\phi^{\prime}=35^{\circ}$, conforme se explica abaixo.

Conforme visto anteriormente neste trabalho, o silte apresenta um plano de foliação bem definido que faz ângulo de cerca de $45^{\circ} \mathrm{com}$ a horizontal. Considerando que é comum planos de foliação apresentarem resistência ao cisalhamento menor que os demais planos de ruptura em um dado solo, concluiu-se que os resultados dos ensaios de cisalhamento direto indicaram a resistência ao cisalhamento do silte em um plano imposto, diferente do plano de foliação, e os resultados dos ensaios de compressão simples indicaram a resistência ao cisalhamento do silte no plano de foliação.

Analisando-se os resultados obtidos nos ensaios de compressão simples segundo as equações propostas por Bishop (1959) e por Fredlund et al. (1978) para solos não saturados, verifica-se incoerência dos dados considerando que houve aumento dos valores de $\phi^{\mathrm{b}}$ com o aumento da sucção, isto é, relação inversa da obtida nos demais ensaios apresentados anteriormente com o silte e com a argila, conforme 
pode ser visto na Tabela 4.11. Verificou-se também que os valores de $\phi^{\mathrm{b}}$ obtidos nesse ensaio são inferiores aos obtidos nos ensaios de cisalhamento direto. Conforme visto anteriormente, esse resultado era esperado considerando que 0 plano de ruptura nos ensaios de compressão simples coincidiu com o plano de foliação, de menor resistência, o que não ocorreu nos ensaios de cisalhamento direto; e que as tensões normais aos planos de ruptura são menores nos ensaios de compressão simples (2 a $19 \mathrm{kPa}$ ) do que nos ensaios de cisalhamento direto (50 a $200 \mathrm{kPa})$.

Tabela 4.11: Parâmetros de Bishop (1959) e por Fredlund et al. (1978) para ensaios de compressão simples

\begin{tabular}{|c|c|c|}
\hline Sucção & $\chi$ & $\boldsymbol{\phi}^{\mathbf{b}}$ \\
\hline$(\mathrm{kPa})$ & - & $\left(^{\circ}\right)$ \\
\hline 27 & 0,34 & 8 \\
\hline 48 & 0,60 & 14 \\
\hline 99 & 0,84 & 19 \\
\hline 457 & 0,05 & 1 \\
\hline
\end{tabular}

Os resultados dos ensaios de compressão simples não saturados podem ser visualizados, juntamente com os resultados dos ensaios de cisalhamento direto não saturados, no gráfico da Figura 4.47. Os resultados dos ensaios de compressão simples indicaram que a coesão aumenta com a sucção até que esse valor atinja 99 $\mathrm{kPa}$, e que a coesão apresenta redução brusca (8 kPa) com sucção de $457 \mathrm{kPa}$. Esse resultado não será utilizado na definição do valor de $\phi^{b}$ e não foi indicado na Figura 4.47.

Os valores de $\phi^{b}$ obtidos nos ensaios de cisalhamento direto e compressão simples para sucções menores ou iguais a $50 \mathrm{kPa}, 35^{\circ}$ e $11^{\circ}$, respectivamente, não são coerentes entre si e isso se justifica por serem resultados de estruturas de solos diversas e que não podem ser comparadas, isto é, plano de foliação e demais planos de ruptura do solo siltoso. Para sucções maiores que $80 \mathrm{kPa}$ e menores que 
$130 \mathrm{kPa}$ os valores médios obtidos para $\phi^{b}$ nos dois tipos de ensaio foram $21^{\circ}$ e $19^{\circ}$, respectivamente.

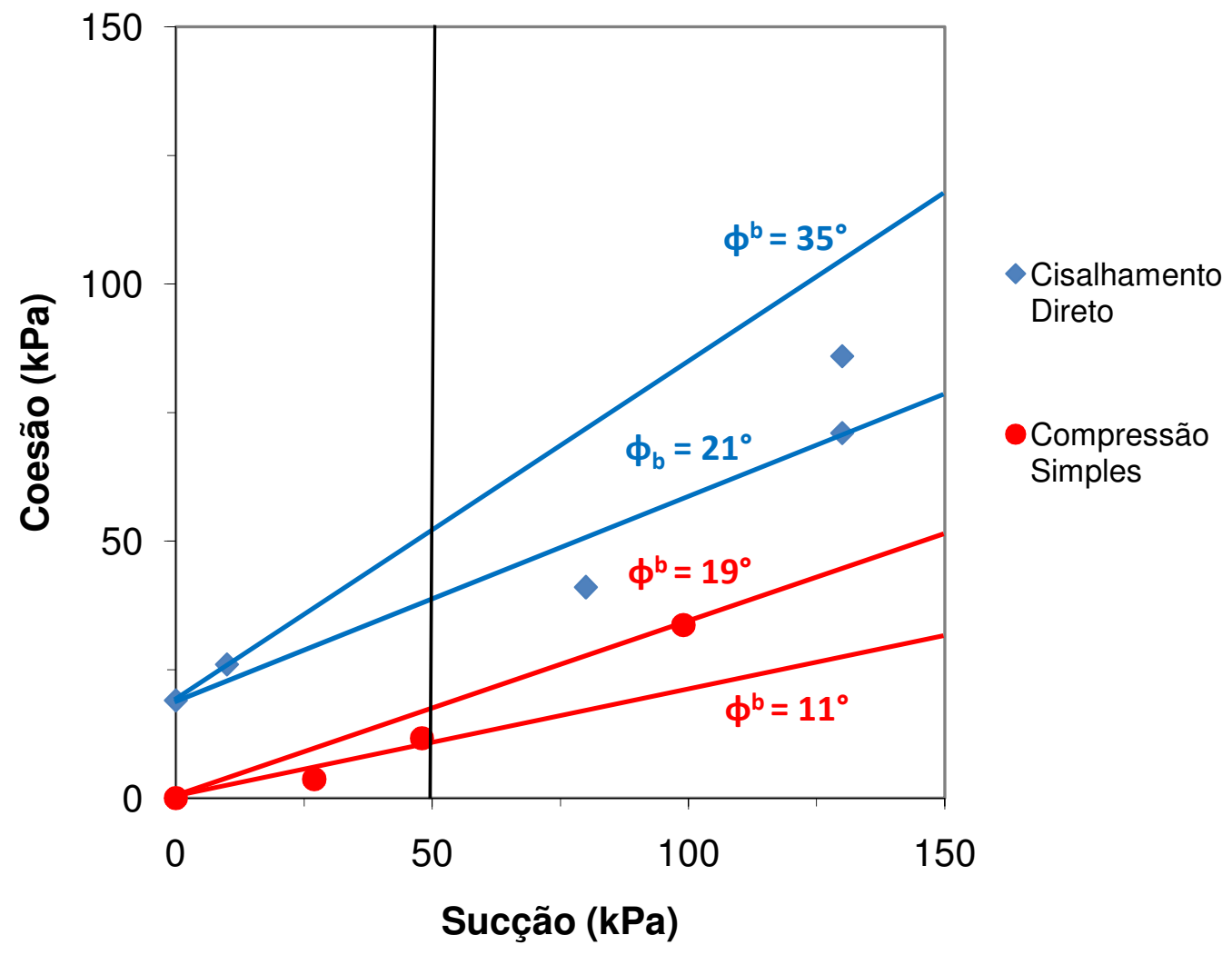

Figura 4.47: Interpretação dos ensaios de compressão simples realizados no silte não saturado

\section{Resistência ao cisalhamento adotada para o silte}

A resistência ao cisalhamento a ser adotada para o silte neste trabalho será utilizada para cálculos de estabilidade do talude experimental, em que foram registradas sucções variando entre 0 e $60 \mathrm{kPa}$ durante o período de monitoramento. Considerando que os valores de $\phi^{b}$ obtidos nos ensaios de cisalhamento direto e compressão simples para essa faixa de sucções são discrepantes, adotou-se o menor valor entre os dois obtidos $\left(\phi^{b}=11^{\circ}\right)$ por ser mais conservador.

Os parâmetros de resistência c' e $\phi^{\prime}$ a serem adotados serão valores médios entre os obtidos nos ensaios de cisalhamento direto $\left(c^{\prime}=19\right.$ e $\left.\phi^{\prime}=35^{\circ}\right)$ e os estimados para o plano de foliação do solo $\left(c^{\prime}=0\right.$ e $\left.\phi^{\prime}=22^{\circ}\right)$ considerando que rupturas em solos com 
plano de foliação normalmente ocorrem parte nesse plano e parte em planos diversos desse.

Os parâmetros efetivos de resistência adotados para o solo siltoso são c' $=5 \mathrm{kPa} e$ $\phi^{\prime}=25^{\circ}$. As equações adotadas segundo os modelos de Bishop (1959) e Fredlund et al. (1978) são, respectivamente:

$$
\begin{aligned}
& s=5+\left[\left(\sigma-u_{a}\right)+0,47\left(u_{a}-u_{w}\right)\right] \operatorname{tg} 25^{\circ} \\
& s=5+\left(\sigma-u_{a}\right) \operatorname{tg} 25^{\circ}+\left(u_{a}-u_{w}\right) \operatorname{tg} 11^{\circ}
\end{aligned}
$$

\section{Ajuste dos parâmetros de resistência}

Da mesma forma que apresentado para a argila foram feitos ajustes hiperbólicos para os parâmetros de resistência do silte não saturado de acordo com os modelos propostos por Futai (2004) e Vilar (2006).

Foram feitos dois ajustes para cada modelo de estimativa da resistência sendo um para cada tipo de ensaio realizado, cisalhamento direto e compressão simples. Os ajustes propostos por Futai (2004) e Vilar (2006) apresentaram resultado similar, para ambos os ensaios, conforme pode ser visto na Figura 4.48, juntamente com as respectivas equações.

Os resultados dos ensaios de cisalhamento direto incluem a coesão para o solo seco ao ar e, portanto os ajustes apresentados são válidos para a estimativa da resistência do silte não saturado, em planos diferentes do plano de foliação, em todas as faixas de sucção. Os resultados dos ensaios de compressão simples indicaram coesão muito abaixo da esperada para o ensaio com sucção igual a 457 $\mathrm{kPa}(8 \mathrm{kPa})$, que foi desconsiderada. Portanto os ajustes propostos por ambos os modelos para os resultados dos ensaios de compressão simples são válidos para se estimar a resistência no plano de foliação do silte, apenas para a faixa de sucção ensaiada, de 0 a $100 \mathrm{kPa}$. 


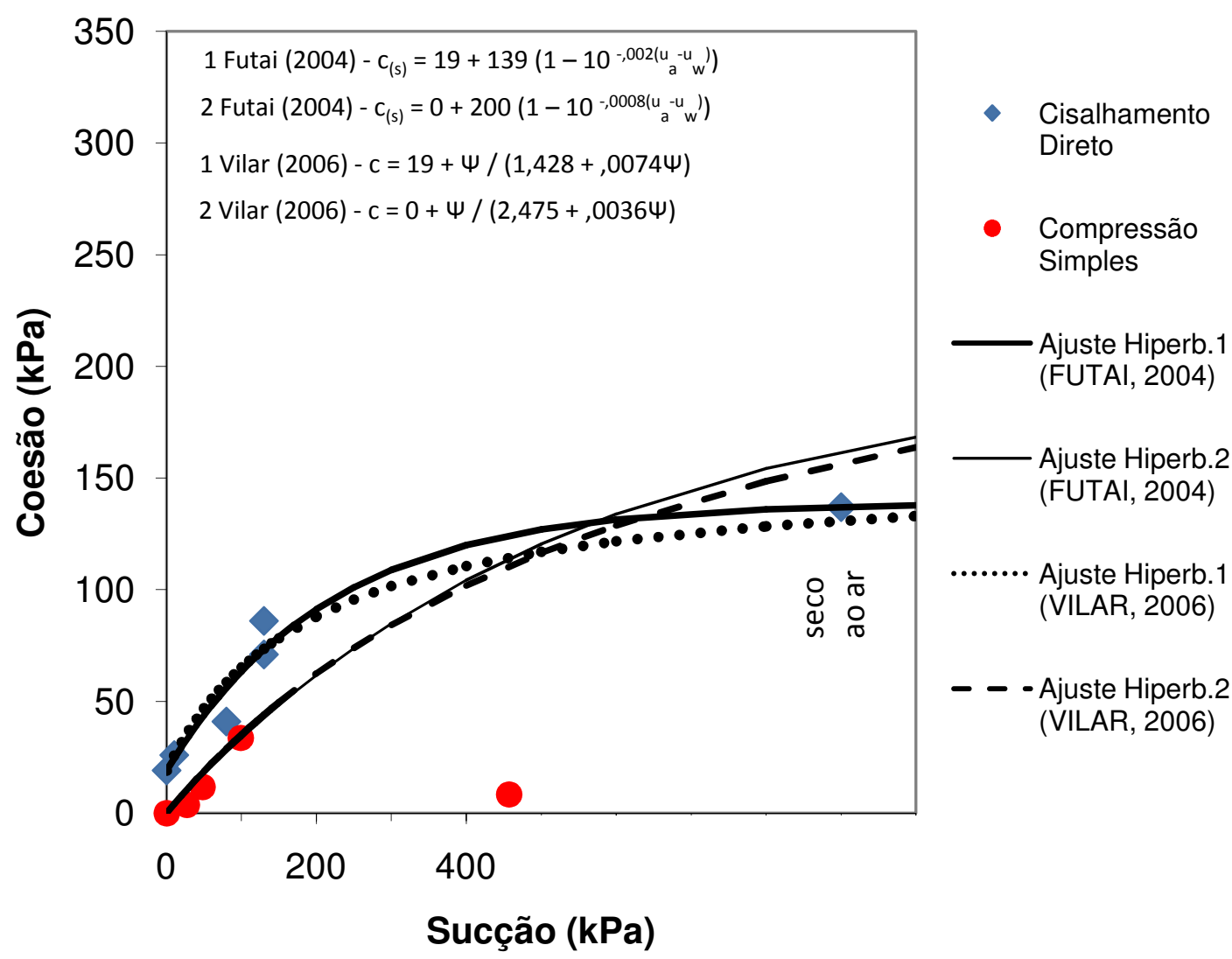

Figura 4.48: Ajustes do intercepto de coesão com ângulo de atrito constante, para os ensaios de cisalhamento direto e compressão simples não saturados, no silte

\subsection{Ensaio de permeabilidade com argamassa de revestimento}

Foram executados ensaios laboratoriais para a determinação do coeficiente de permeabilidade da argamassa de revestimento do talude experimental. Os ensaios foram realizados com carga variável, em quatro corpos de prova retirados de diferentes porções do talude.

Os corpos de prova ensaiados têm cerca de $25 \mathrm{~cm}$ de diâmetro com forma irregular e aproximadamente $1,5 \mathrm{~cm}$ de espessura. Foram lavados para remoção de solo aderido às suas superfícies, e após a secagem foram fixados à extremidade de maior diâmetro de funis de plástico, com uso de silicone de vedação. $\mathrm{Na}$ extremidade com menor diâmetro do funil foi fixada bureta graduada utilizando-se 
fita de vedação, conforme apresentado na Figura 4.49. Antes do ensaio os corpos de prova foram saturados e as buretas foram completadas com água.

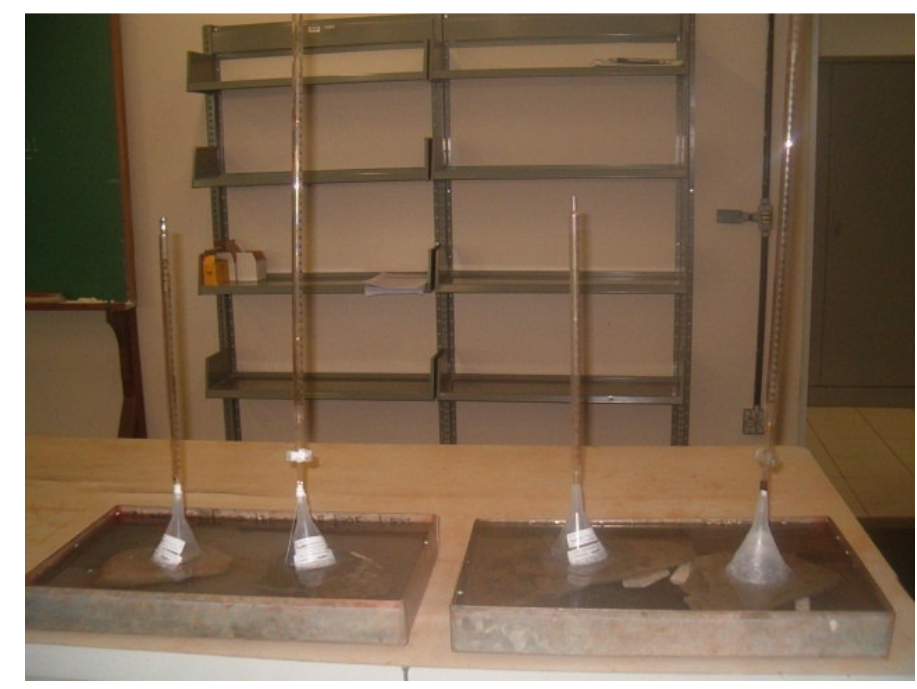

Figura 4.49: Ensaio de permeabilidade em argamassa

O ensaio consistiu em: colocar o corpo de prova em recipiente com água até recobrir as amostras; preencher a bureta com água; e fazer leituras do nível d'água e do tempo transcorrido a partir do preenchimento da bureta. Foram feitos diversos ensaios com os corpos de prova. A média dos resultados obtidos para o coeficiente de permeabilidade da argamassa nos ensaios realizados com os três corpos de prova foi de $2,8 \times 10^{-6} \mathrm{~cm} / \mathrm{s}$ conforme mostra a Figura 4.50 .

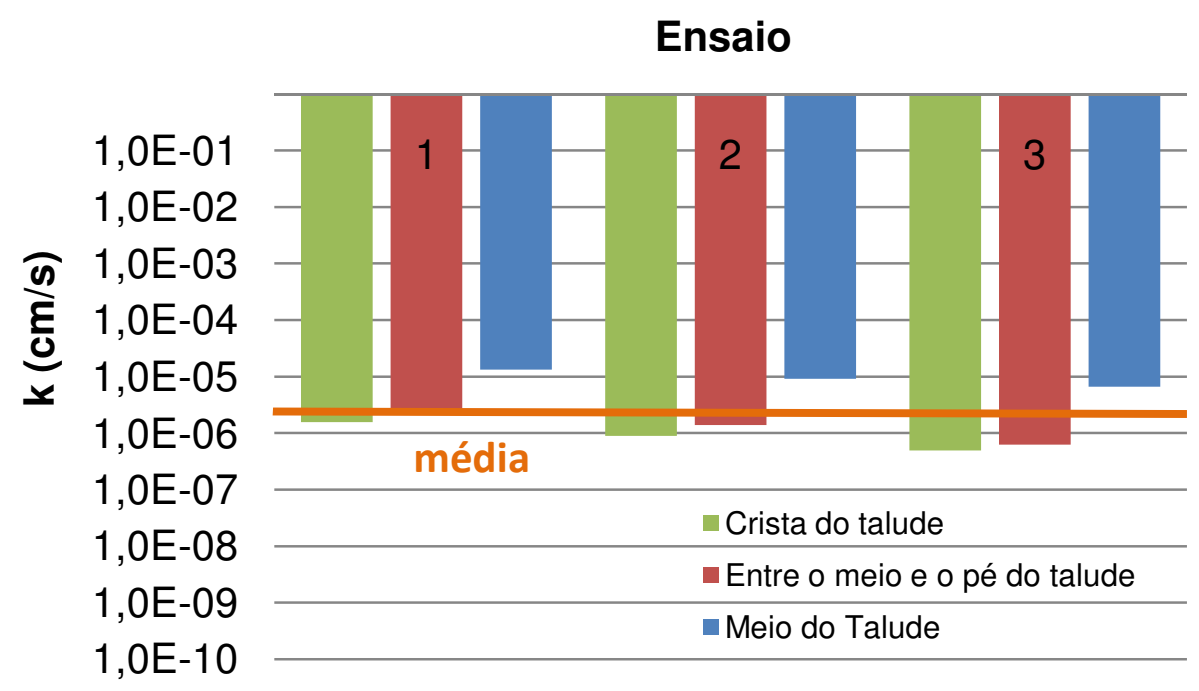

Figura 4.50: Resultados dos ensaios de permeabilidade: corpos de prova 1, 2 e 3 
O coeficiente de permeabilidade saturado da argamassa obtido nos ensaios descritos acima é coerente com o processo de mistura utilizado, por meio de enxada sobre masseira, e com o elevado fator água/cimento, consistência entre líquida e pastosa. É coerente também com os valores médios de coeficiente de permeabilidade do concreto, $10^{-9} \mathrm{~cm} / \mathrm{s}$, e do concreto fissurado, $10^{-4} \mathrm{~cm} / \mathrm{s}$, Segundo Cruz (1996), ficando entre os dois valores.

A permeabilidade da argamassa é maior que a permeabilidade vertical do aterro argiloso medido em ensaio com permeâmetro Triflex, apresentada neste trabalho, $2,2 \times 10^{-7} \mathrm{~cm} / \mathrm{s}$, e menor que a do solo residual siltoso, $1,2 \times 10^{-4} \mathrm{~cm} / \mathrm{s}$. Donde se conclui que a argamassa aplicada sobre $o$ aterro argiloso não funciona como uma barreira impermeabilizante, e que pode contribuir para a diminuição da infiltração de água de chuva no solo siltoso.

\subsection{Ensaio de infiltração em infiltrômetro de duplo-anel com medição de poro- pressão de água}

Ensaio de Infiltração em Infiltrômetro de Duplo-Anel com Medição de Poro-pressão de Água foi realizado na crista do talude experimental, em solo argiloso. Este ensaio foi programado com o objetivo de se conhecer: (a) a direção de maior infiltração de água considerando que o solo ensaiado tem característica anisotrópica com respeito à permeabilidade; (b) a velocidade de avanço da frente de umedecimento durante 0 ensaio; e (c) comparar os resultados obtidos com simulação do ensaio no software Seep/W.

Os resultados desses ensaios fornecem melhores informações sobre o avanço das frentes de umedecimento do que as medições diárias de campo, pois no dia a dia das leituras, diversas frentes de umedecimento (chuva) e secagem (evaporação e evapo-transpiração) interagem dificultando a interpretação dos resultados de campo.

O ensaio de infiltração em Infiltrômetro de Duplo-Anel foi realizado em dois anéis concêntricos medindo $75 \mathrm{~cm}$ e $150 \mathrm{~cm}$ de diâmetro cada, seguindo as orientações da norma ASTM D 3385-03, Standard Test Method for Infiltration Rate of Soils in 
Field Using Double-Ring Infiltrometer. Os anéis foram construídos em alvenaria de tijolos maciços revestidos com argamassa e tinta betuminosa, conforme pode ser visto na Figura 4.51. A implantação do experimento se deu na crista do talude experimental, onde há camada de 3 metros de espessura de aterro argiloso, e solo residual siltoso subjacente.

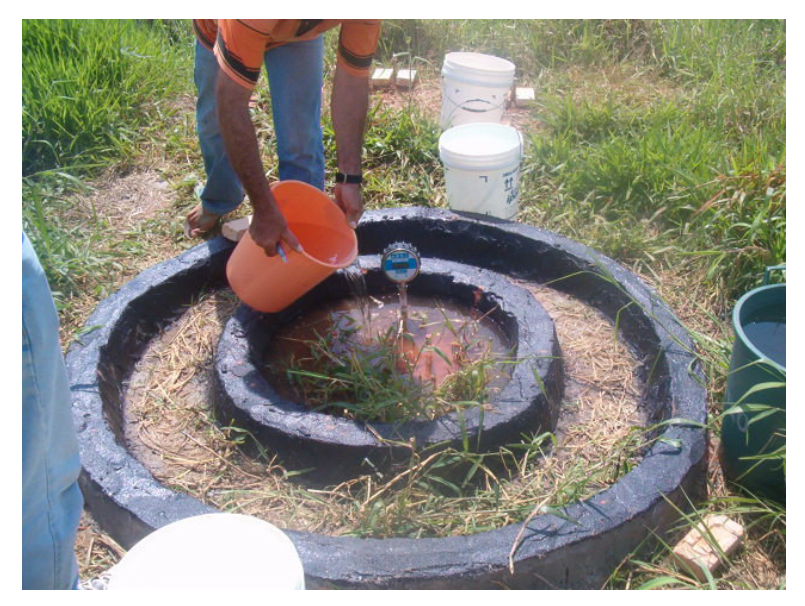

Figura 4.51: Ensaio Infiltração em Infiltrômetro de duplo-anel com medição de poropressão de água

Os dados de poro-pressão de água foram obtidos por meio 12 tubos tensiométricos instalados em três profundidades em relação ao nível do terreno $(0,5 \mathrm{~m}, 1,5 \mathrm{~m}$ e 3,0 $\mathrm{m})$ e em quatro distâncias em relação ao centro dos anéis de infiltração $(0,1 \mathrm{~m}, 1,5$ m, 2,5 m e 7,5 m) conforme pode ser visto na Figura 4.52, juntamente com o perfil de poro-pressão de água no terreno, no início do ensaio. Observa-se nessa figura que o talude apresentava em sua maior parte poro-pressões positivas, refletindo 0 período do ano (chuvoso) em que foi realizado o ensaio, novembro de 2005, e condição de lençol freático suspenso, verificado em grande parte do período de monitoramento nessa região do talude, a crista.

O ensaio consistiu no preenchimento dos anéis com água até uma altura de sete centímetros, e na manutenção do nível de água constante durante seis horas. A quantidade de água adicionada foi registrada a intervalos de tempo constantes para determinação da taxa de infiltração. Foram feitas leituras de poro-pressão de água antes, durante e após o término do ensaio de infiltração. A área experimental foi 
recoberta com lona plástica cinco dias antes do ensaio para que eventuais precipitações não interferissem no ensaio. O nível d'água "suspenso" na camada ensaiada, quando do início do ensaio encontrava-se a cerca de $1,0 \mathrm{~m}$ de profundidade conforme pode ser visto na Figura 4.52.

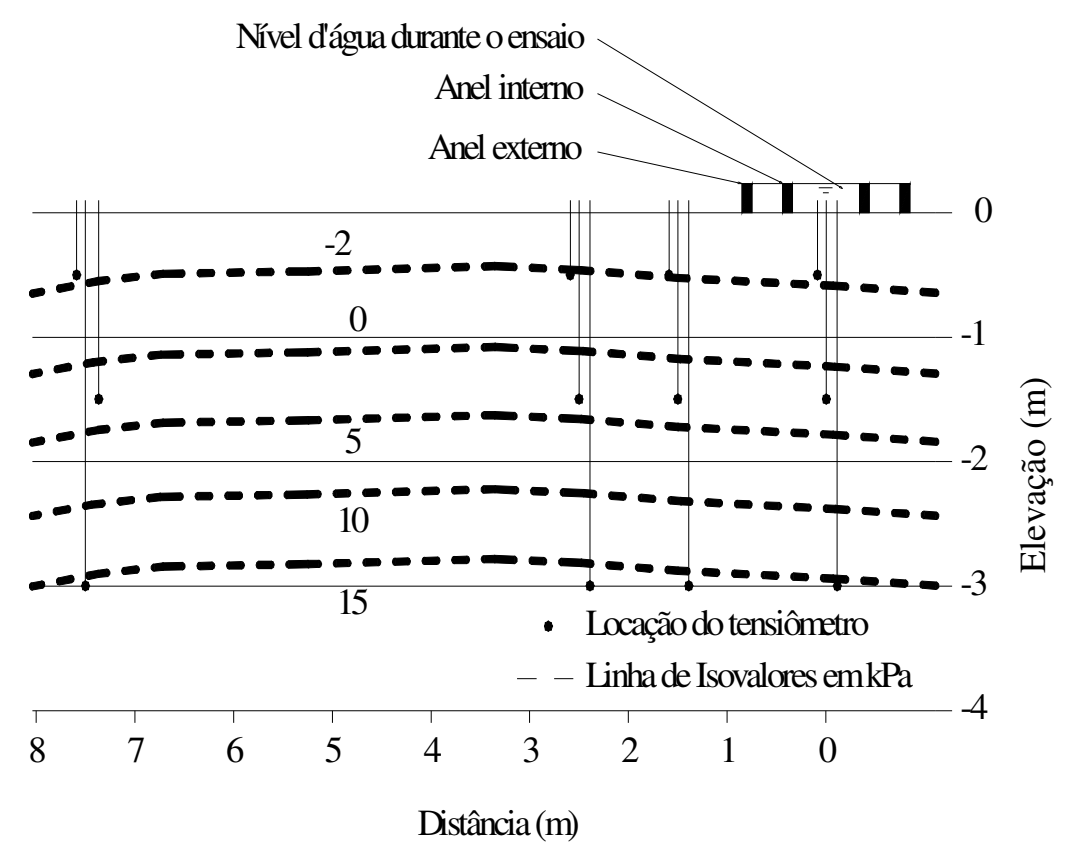

Figura 4.52: Secção esquemática da locação dos instrumentos; magnitude e distribuição de poro-pressão de água no terreno antes do início do ensaio de infiltração.

A taxa de infiltração obtida no Ensaio de Infiltração em Duplo-Anel foi $3,0 \times 10^{-3}$ $\mathbf{c m} / \mathbf{s}$, muito superior ao coeficiente de permeabilidade vertical saturado do solo medida em laboratório $\left(2,2 \times 10^{-7} \mathrm{~cm} / \mathrm{s}\right)$, que seu coeficiente de permeabilidade horizontal saturado $\left(2,5 \times 10^{-6} \mathrm{~cm} / \mathrm{s}\right)$, e que o coeficiente de permeabilidade medido em campo com $\circ$ Permeâmetro de Guelph, que registrou $2,0 \times 10^{-7} \mathrm{~cm} / \mathrm{s}$. O coeficiente de permeabilidade do solo durante o ensaio de infiltração corresponde ao coeficiente de permeabilidade saturado, considerando que o solo apresenta elevado ponto de entrada de ar. Durante o ensaio ocorreu surgência de água na superfície do terreno próximo dos anéis de infiltração, em grande quantidade. Supõe-se que esse fato explique a elevada taxa de infiltração obtida no ensaio. 
As leituras de poro-pressão de água nos tensiômetros indicaram uma resposta coerente com a realização do ensaio de infiltração. Isto é, as leituras que vinham caindo nas horas que precederam a realização do ensaio passaram a crescer após um intervalo de tempo variável. Após o período de crescimento de poro-pressão de água as leituras passaram a cair refletindo o final da infiltração. Nas Figuras 4.53 a 4.56 são apresentadas as leituras de poro-pressão de água antes, durante e após o ensaio que durou 6 horas, nos quatro pontos instrumentados. Os afastamentos desses pontos até o centro dos anéis são: $0,1 \mathrm{~m}, 1,5 \mathrm{~m}, 2,5 \mathrm{~m}$ e 7,5 m. Os pontos escuros indicados nessas figuras representam o momento em que foi registrada elevação das poro-pressões de água, em cada profundidade instrumentada.

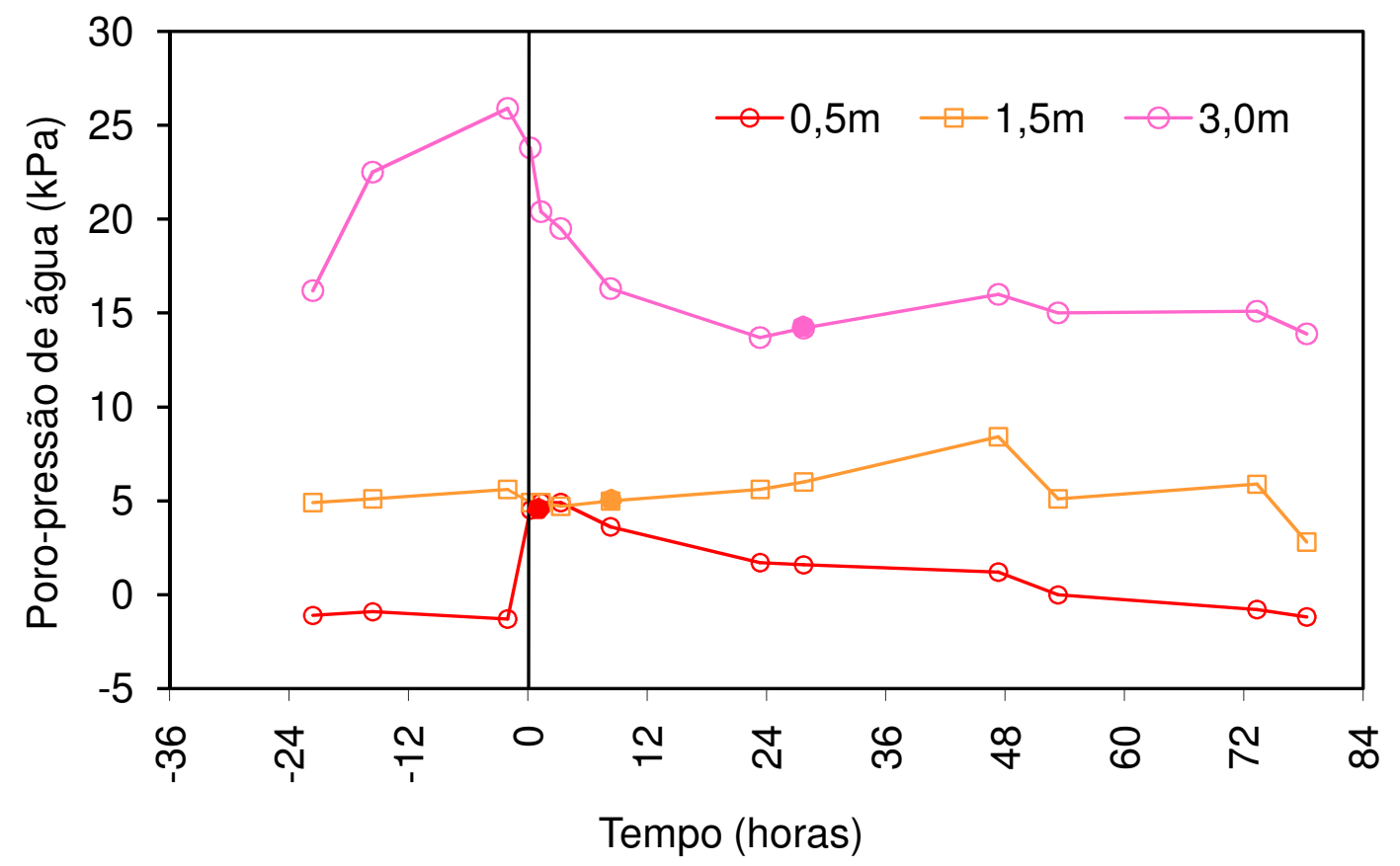

Figura 4.53: Variação da poro-pressão medido antes, durante e após o término do ensaio, no centro dos anéis de infiltração 


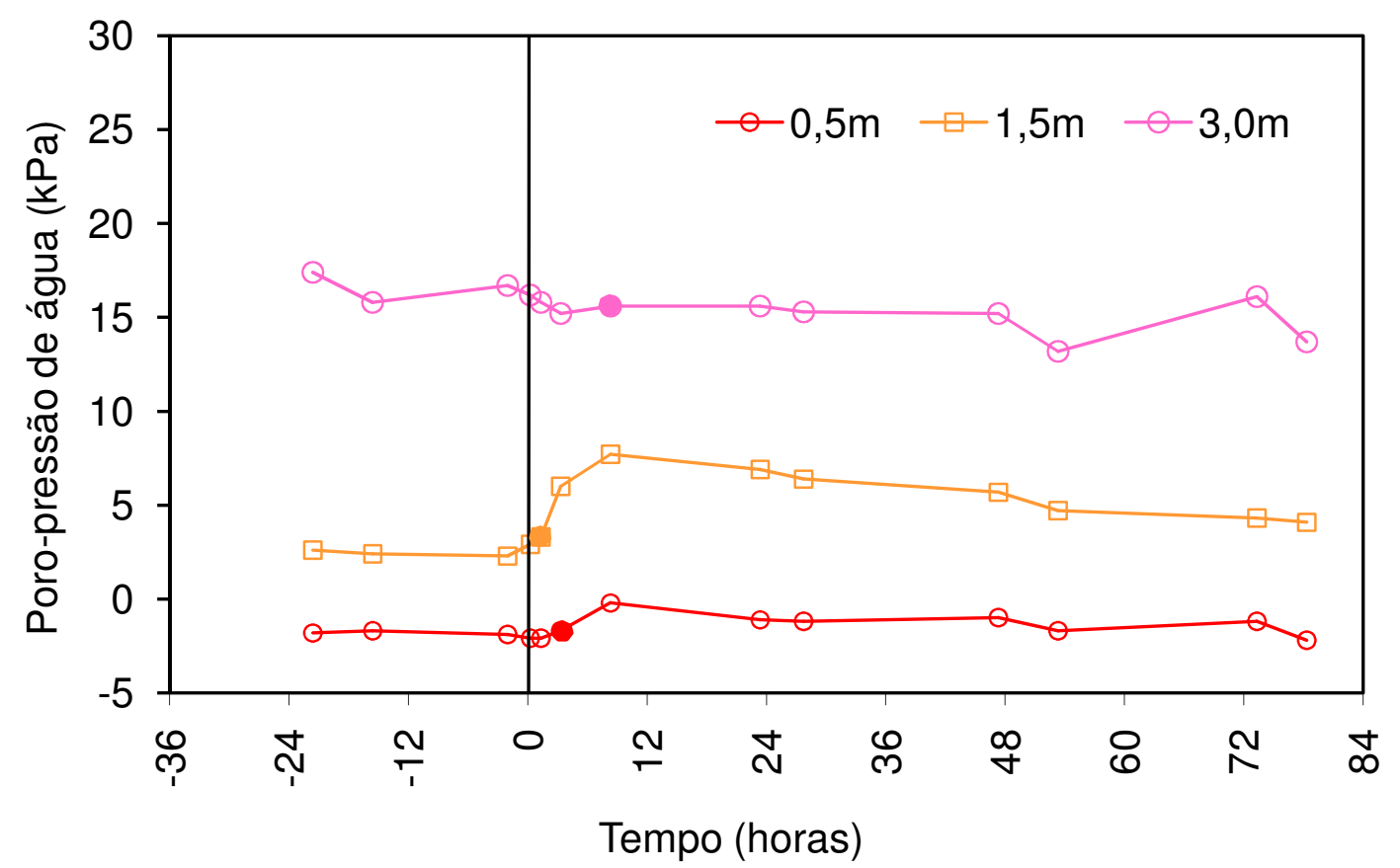

Figura 4.54: Variação da poro-pressão medido antes, durante e após o término do ensaio, a 1,5 metros de distância (horizontal) do centro dos anéis de infiltração

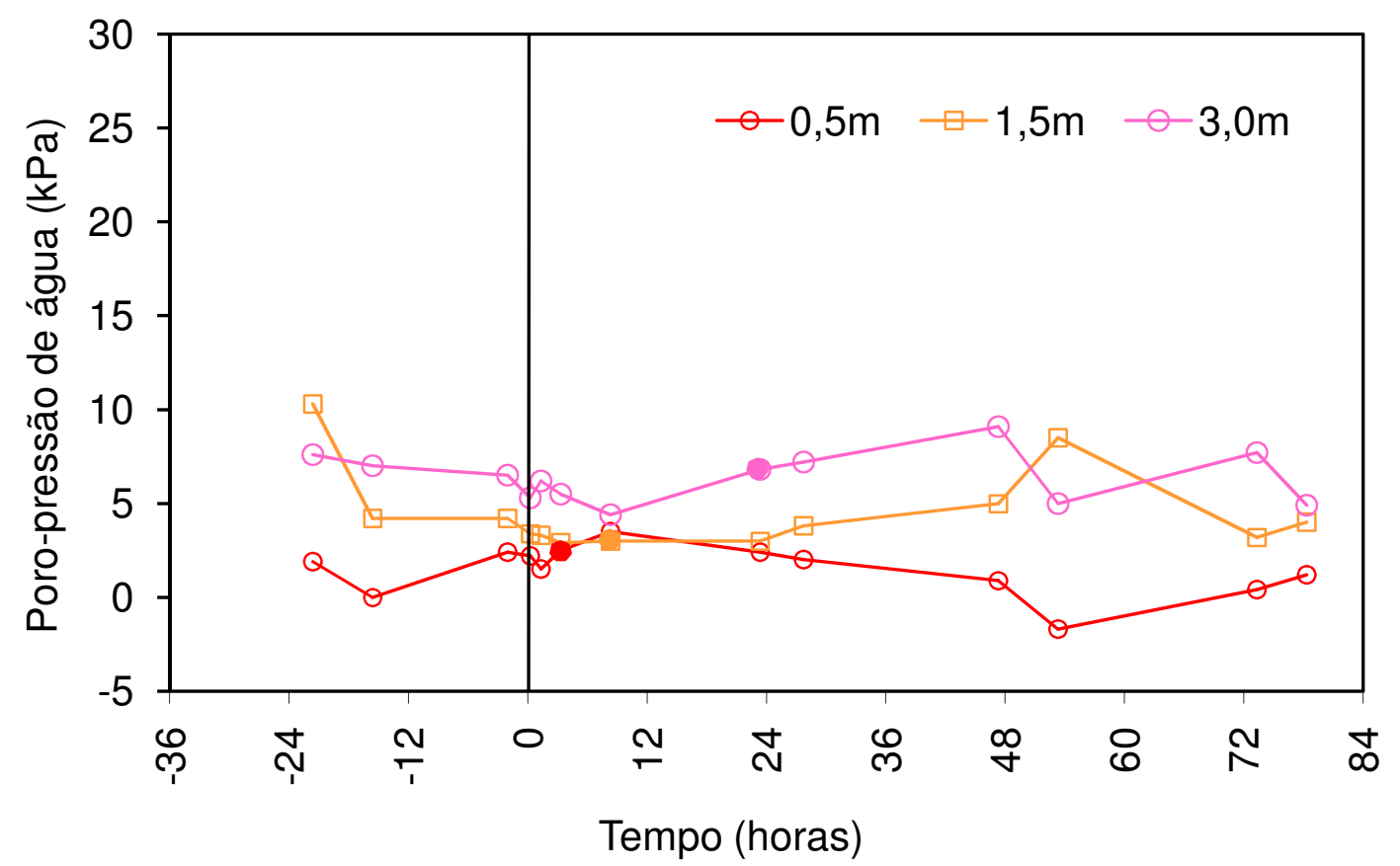

Figura 4.55: Variação da poro-pressão medido antes, durante e após o término do ensaio, a 2,5 metros de distância (horizontal) do centro dos anéis de infiltração 


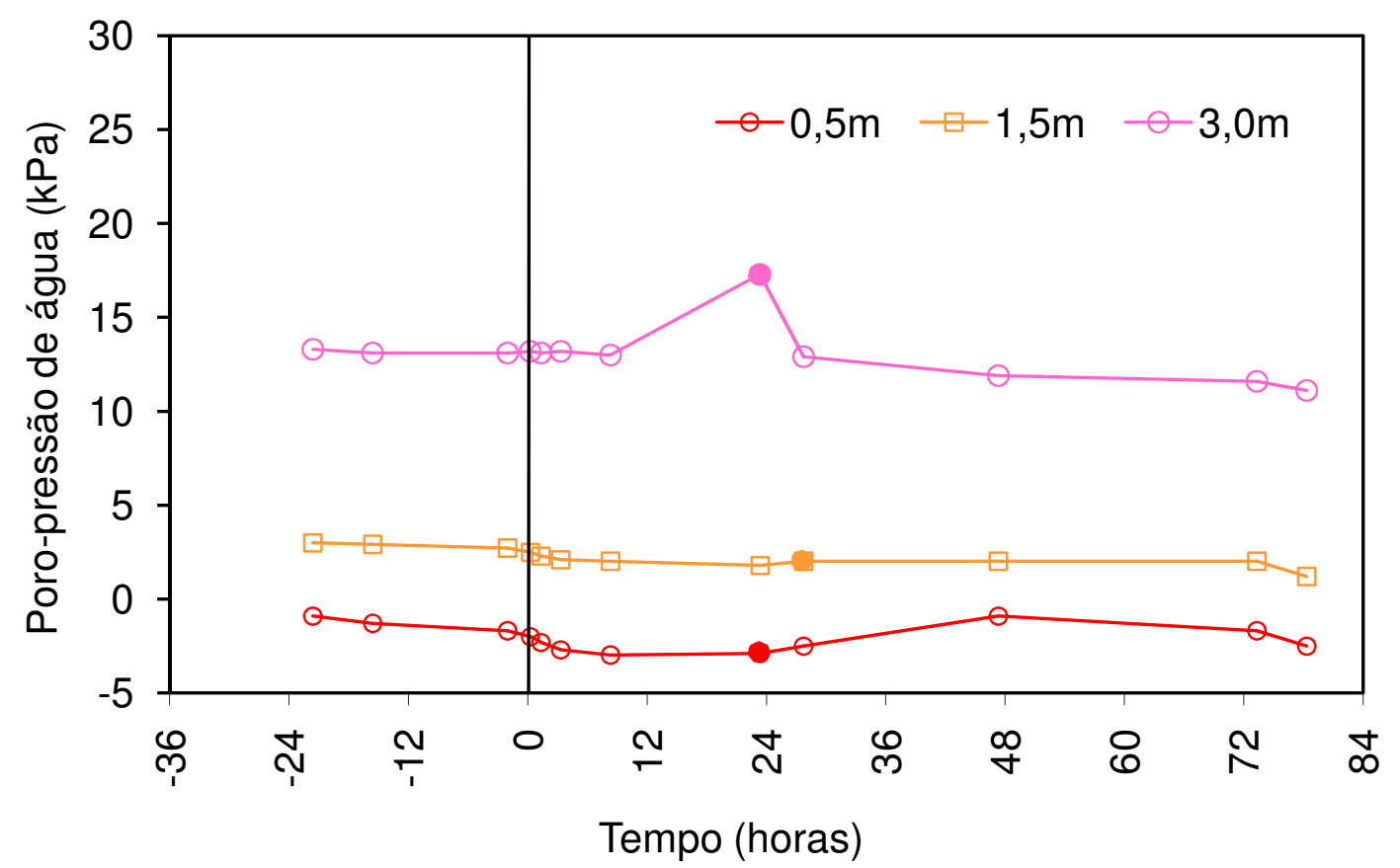

Figura 4.56: Variação da poro-pressão medido antes, durante e após o término do ensaio, a 7,5 metros de distância (horizontal) do centro dos anéis de infiltração

O ensaio de infiltração provocou elevação das leituras de poro-pressão de água nos tensiômetros localizados até $7,5 \mathrm{~m}$ de distância do centro dos anéis de infiltração e nos tensiômetros instalados até $3,0 \mathrm{~m}$ de profundidade.

Verificou-se também que o acréscimo de poro-pressão de água, na região instrumentada, provocado pelo ensaio de infiltração, variou entre $0,4 \mathrm{kPa}$ a $6,2 \mathrm{kPa}$, conforme a localização do tensiômetro. Os maiores acréscimos localizaram-se ao longo de uma linha que parte do centro dos anéis de infiltração e que faz $30^{\circ} \mathrm{com}$ a horizontal. Supõe-se que isso pode ser explicado pela anisotropia do solo em relação à permeabilidade.

Conforme pode ser visto na Figura 4.53, houve variação da poro-pressão de água a 3,0 $\mathrm{m}$ de profundidade no centro dos anéis 28 horas após o inicio do ensaio, passando de 13,7 kPa para 14,2 $\mathrm{kPa}$. Verificou-se que houve uma variação rápida da poro-pressão de água nesse e em outros pontos instrumentadas, considerando a 
permeabilidade da argila. Esse tipo de resultado foi descrito na literatura e foi justificado pela possibilidade de ocorrer infiltração em "fingers" ou outras macroestruturas, conforme apresentado na revisão bibliográfica deste trabalho, resultando em coeficiente de permeabilidade em campo maior do que o medido em laboratório.

Descarta-se a possibilidade de que o coeficiente de permeabilidade da argila medido em ensaios laboratoriais não represente a permeabilidade de campo, pois foi confirmado por ensaio realizado em campo com Permeâmetro de Guelph. Supõe-se que as hipóteses propostas por Carvalho (1989) de que ocorra fluxo em fendas ou trincas no solo, e por Santos (2004), infiltração em "fingers", possam ser desconsideradas para explicar os resultados aqui apresentados.

Com o objetivo de auxiliar a interpretação das leituras de poro-pressão de água obtidas em campo, fez-se uma simulação do ensaio de infiltração no programa Seep/W. A simulação do ensaio considerou como dados de entrada o perfil inicial de poro-pressão de água obtido em campo duas horas antes do início do ensaio, a curva de retenção do solo ensaiado (argila), a função permeabilidade do solo, as permeabilidades vertical e horizontal do solo, e a infiltração radial de água (raio igual a $75 \mathrm{~cm}$ ) com duração de seis horas.

Os resultados obtidos na simulação são apresentados na Figura 4.51. O avanço da frente de infiltração pode ser analisado nesta figura considerando três intervalos de tempo: três horas, seis horas e sete horas e meia após o início do ensaio. A frente de infiltração atingiu uma distância máxima na horizontal de aproximadamente 3,0m e na vertical de apenas $1,0 \mathrm{~m}$ no centro dos anéis de infiltração. $A$ análise numérica mostrou que o avanço da frente de infiltração não provocou variação de poropressão de água nos tensiômetros situados a $7,5 \mathrm{~m}$ do centro do ensaio, e nos tensiômetros instalados a $1,5 \mathrm{~m}$ e 3,0 $\mathrm{m}$ de profundidade.

Comparando-se os resultados obtidos em campo com os resultados da análise numérica, verifica-se que o aumento da poro-pressão de água no solo, medido em campo, atinge profundidades significativamente maiores $(3,0 \mathrm{~m})$ do que as 
verificadas na simulação em computador (1,0 m). Há indícios de que as equações de fluxo utilizadas pelo software não resultem em variações de poro-pressão de água similares às obtidas experimentalmente, que ocorreriam por meio de outro fenômeno, além do fluxo de água.

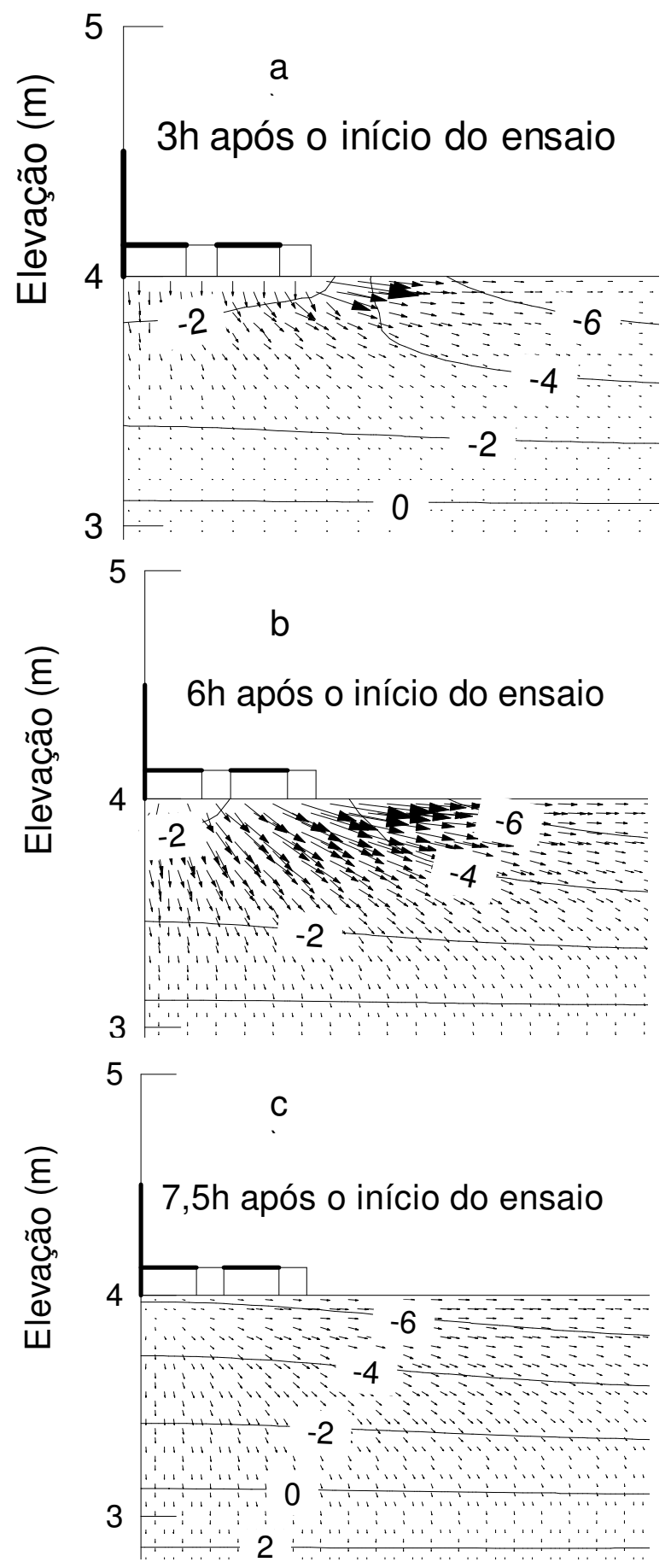

Figura 4.57: Resultados da análise numérica obtidos em três intervalos de tempo, apresentando a variação dos valores de poro-pressão da água em $\mathrm{kPa}$ : a) três horas; b) seis horas e c) sete horas e meia após o início do ensaio 


\section{MONITORAMENTO DO TALUDE EXPERIMENTAL}

O monitoramento do talude experimental foi realizado com: pluviômetro, medidor de nível d'água e tensiômetros. O período de monitoramento foi de janeiro a setembro de 2005, durante 261 dias. De janeiro a abril (período chuvoso) as leituras dos instrumentos foram feitas diariamente, e de maio a setembro (período de estiagem) semanalmente, com aumento da freqüência das leituras (diárias) quando da ocorrência de chuvas intensas.

As leituras de poro-pressão de água foram feitas com tensímetro digital fornecido pelo fabricante 1 , durante 56 dias, no período de três de janeiro a 28 de fevereiro. Nesse período o tensímetro digital quebrou por três vezes e foi sendo substituído a cada vez. Optou-se então por tensímetro analógico de punção fornecido pelo mesmo fabricante. De primeiro de março a oito de abril (38 dias) as leituras nos tubos tensiométricos foram feitas com tensímetro analógico, cujos resultados foram incoerentes e não foram incluídos neste trabalho. As demais leituras (167 dias) foram feitas com tensímetro digital fornecido por um segundo fabricante, que não apresentou defeitos até o final do experimento.

A manutenção dos tubos tensiométricos foi feita semanalmente retirando-se a tampa de silicone e preenchendo-os com água filtrada. A leitura dos instrumentos foi realizada por uma auxiliar treinada para a execução dos serviços. A inspeção foi realizada pelo autor semanalmente visando analisar a coerência dos dados obtidos no período, orientar a anotação das leituras, solucionar dificuldades encontradas e enviar instrumentos para a assistência técnica, quando necessário. Na Figura 5.1 pode-se ver o tensímetro inserido no tubo tensiométrico com bloco de concreto de proteção sobre a parte externa do tubo. 


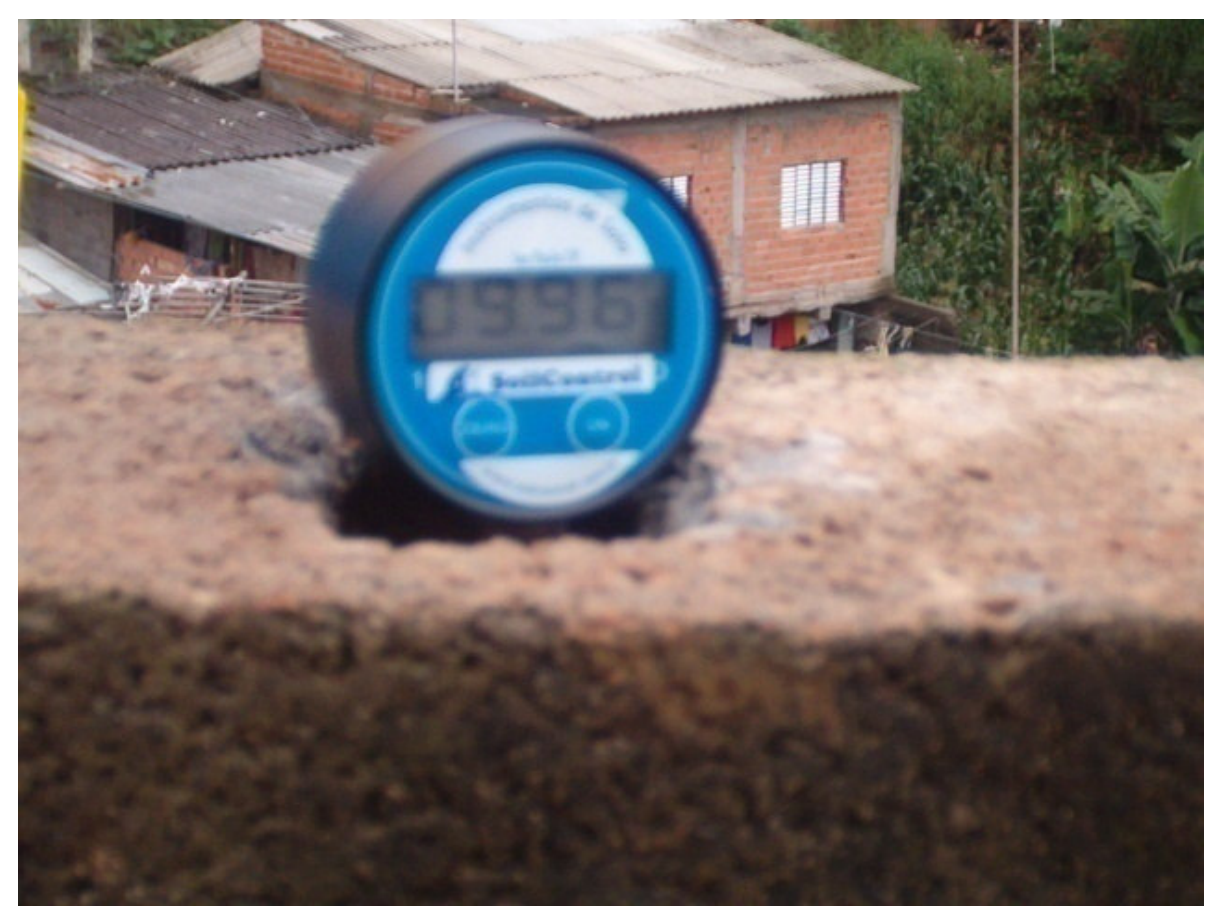

Figura 5.1: Tensímetro inserido em tubo tensiométrico, com proteção em bloco de concreto da extremidade superior do tubo

Nas Figuras 5.2 e 5.3 abaixo são apresentadas as seções geotécnicas do talude experimental nas porções com revestimento em argamassa e em vegetação, respectivamente. Nas seções são indicadas as posição relativas e o arranjo da instrumentação, em cinco linhas de tubos tensiométricos localizadas na crista do talude (Linha 1), entre a crista e o meio do talude (Linha 2), no meio do talude (Linha 3), entre o meio e o pé do talude (Linha 4), e no pé do talude (Linha 5). Os tensiômetros foram identificados em função da porção do talude em que se encontram: argamassada $(A)$, vegetação $(V)$, e da linha em que se encontram (1 a 5), sendo A1 a A5 e V1 a V5. O medidor de nível d'água localiza-se no pé do talude, em seu trecho argamassado.

A crista do talude encontra-se na cota $835,35 \mathrm{~m}$ e o pé do talude localiza-se nas cotas 820,35 m (porção argamassada) e 821,15 m (porção com vegetação), ou 80 $\mathrm{cm}$ mais elevado na porção com vegetação. Na porção argamassada o pé do talude fica mais próximo do nível d'água, 2,9 m em 07/01/05, que na porção com vegetação, 3,7 m na mesma data. 


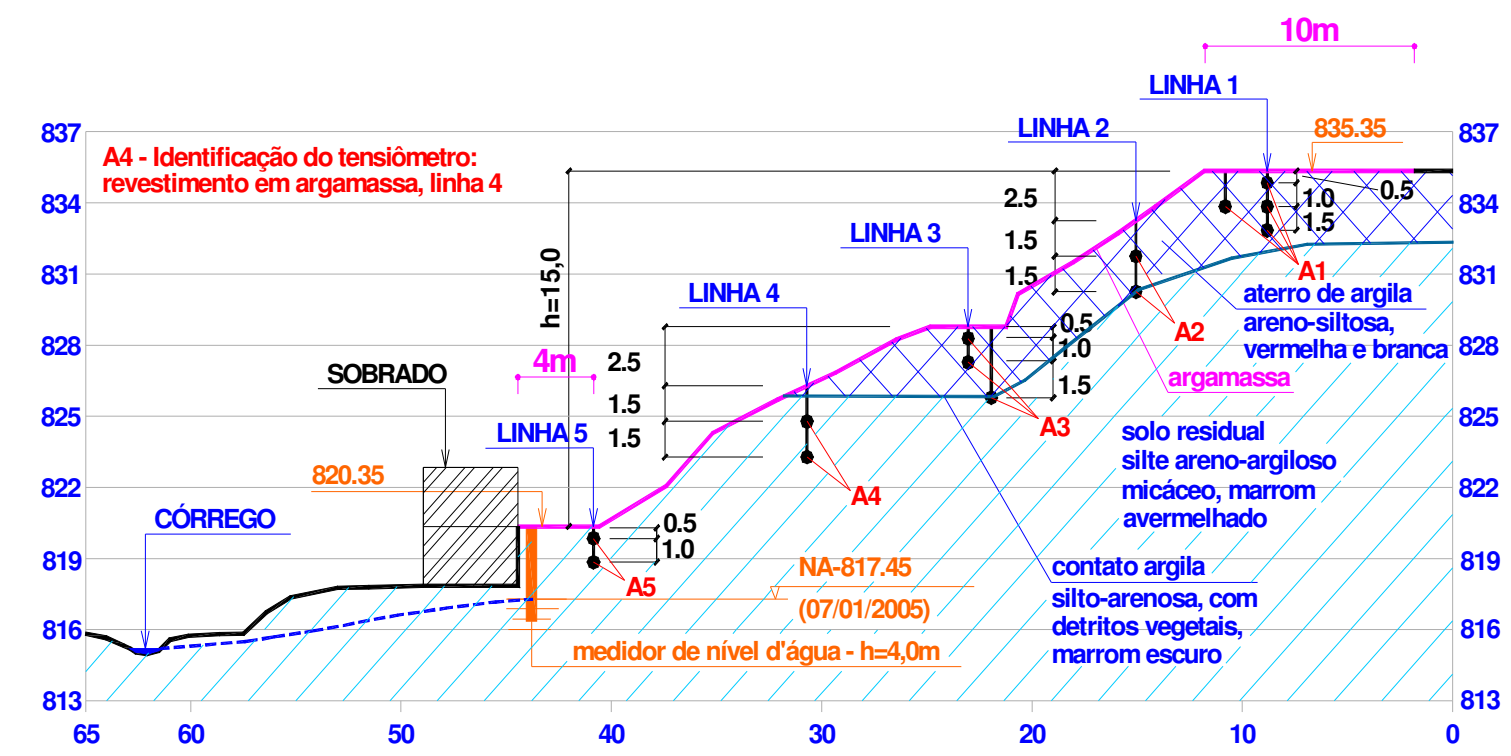

Figura 5.2: Seção 1 - Diagrama esquemático da posição relativa e arranjo da instrumentação de campo, e perfil geotécnico, na porção argamassada do talude

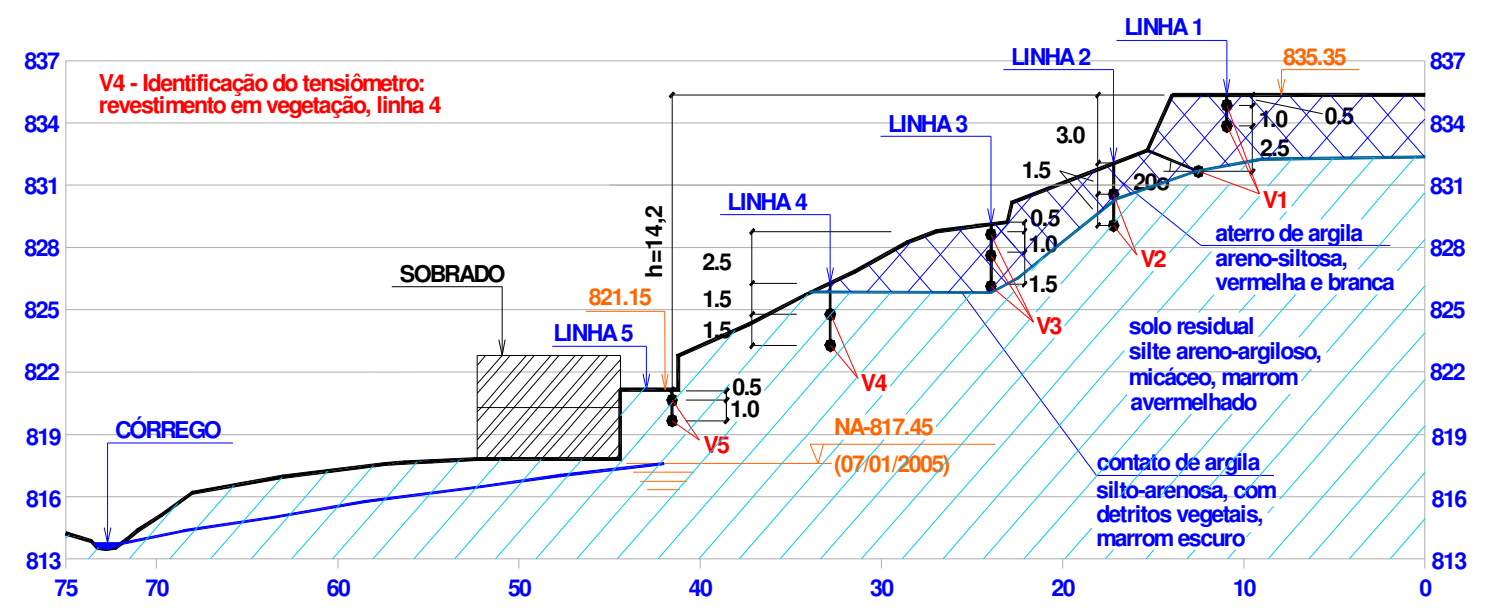

Figura 5.3: Seção 2 - Diagrama esquemático da posição relativa e arranjo da instrumentação de campo, e perfil geotécnico, na porção do talude com vegetação

Os tensiômetros encontram-se instalados em argila areno-siltosa e silte arenoargiloso. Na Tabela 5.1 são indicadas a localização e a identificações dos tensiômetros, e o tipo de solo em que se encontram instalados. 
Tabela 5.1: Posição relativa dos tensiômetros em relação aos solos existentes no talude

\begin{tabular}{|c|c|c|c|c|}
\hline Linha & $\begin{array}{r}\text { Prof. } \\
\text { (m) }\end{array}$ & $\begin{array}{l}\text { Revesti- } \\
\text { mento }\end{array}$ & $\begin{array}{l}\text { Identificação } \\
\text { Tensiômetro }\end{array}$ & Solo \\
\hline \multirow{3}{*}{$\begin{array}{c}1 \\
\text { (Crista) }\end{array}$} & 0,5 & Vegetação & V1-0,5 & \multirow{7}{*}{ Argila } \\
\hline & 1,5 & Vegetação & $\mathrm{V} 1-1,5$ & \\
\hline & 4,0 & Vegetação & V1-4,0 & \\
\hline \multirow{3}{*}{$\begin{array}{c}1 \\
\text { (Crista) }\end{array}$} & 0,5 & Argamassa & $A 1-0,5$ & \\
\hline & 1,5 & Argamassa & A1-1,5 & \\
\hline & 3,0 & Argamassa & $\mathrm{A} 1-3,0$ & \\
\hline \multirow{2}{*}{2} & 1,5 & Vegetação & V2-1,5 & \\
\hline & 3,0 & Vegetação & V3-3,0 & Silte \\
\hline \multirow{2}{*}{2} & 1,5 & Argamassa & A2-1,5 & \multirow{8}{*}{ Argila } \\
\hline & 3,0 & Argamassa & A2-3,0 & \\
\hline \multirow{3}{*}{3 (Meio) } & 0,5 & Vegetação & V3-0,5 & \\
\hline & 1,5 & Vegetação & V3-1,5 & \\
\hline & 3,0 & Vegetação & V3-3,0 & \\
\hline \multirow{3}{*}{3 (Meio) } & 0,5 & Argamassa & A3-0,5 & \\
\hline & 1,5 & Argamassa & A3-1,5 & \\
\hline & 3,0 & Argamassa & A3-3,0 & \\
\hline \multirow{2}{*}{4} & 1,5 & Vegetação & V4-1,5 & \multirow{8}{*}{ Silte } \\
\hline & 3,0 & Vegetação & V4-3,0 & \\
\hline \multirow{2}{*}{4} & 1,5 & Argamassa & A4-1,5 & \\
\hline & 3,0 & Argamassa & $A 4-3,0$ & \\
\hline \multirow{2}{*}{5} & 0,5 & Vegetação & V5-0,5 & \\
\hline & 1,5 & Vegetação & V5-1,5 & \\
\hline \multirow{2}{*}{5} & 0,5 & Argamassa & A5-0,5 & \\
\hline & 1,5 & Argamassa & A5-1,5 & \\
\hline
\end{tabular}

\subsection{Pluviometria}

Os resultados da medição da pluviometria no campo experimental durante 0 ano de 2005 indicaram meses menos chuvosos que a média histórica do Posto 
Pluviométrico da Luz (período de retorno de 100 anos) localizado no centro de São Paulo, capital. Choveu $15 \%$ menos no período do experimento, janeiro a setembro, $819 \mathrm{~mm}$, do que a média histórica do Posto da Luz para o mesmo período, $960 \mathrm{~mm}$. Comparando-se a pluviometria do campo experimental com os dados pluviométricos do Posto Jd. Centenário na Bacia do Rio Aricanduva (período de retorno de 20 anos), a queda foi de $20 \%$.

No mês de fevereiro a precipitação no campo experimental foi de $74 \mathrm{~mm}$, muito abaixo das médias históricas dos postos analisados, cerca de $200 \mathrm{~mm}$ nos dois postos pluviométricos analisados. O mês de maio foi exceção, com chuvas significativamente maiores que as médias históricas, $158 \mathrm{~mm}$ contra cerca de 75 $\mathrm{mm}$, conforme apresentado na Figura 5.4.

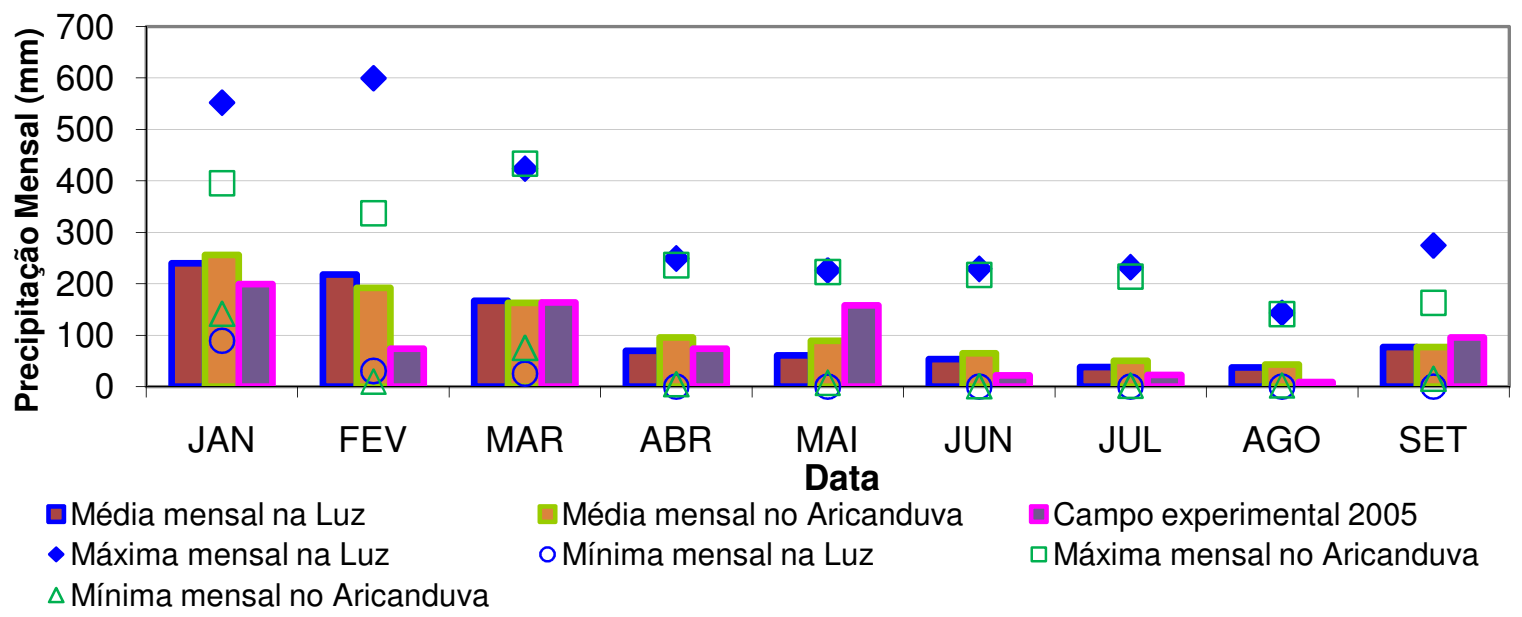

Figura 5.4: Pluviometria mensal no campo experimental comparada com a média de postos pluviométricos

Em um único dia de maio (24/05/2005) choveu 127 mm, maior leitura diária durante o experimento. Essa precipitação diária é maior que a máxima em 20 anos (1973 a 1992) de registros do Posto Jd. Centenário, $115 \mathrm{~mm}$. É também a quarta maior precipitação diária em cem anos de registros do Posto da Luz, que registrou máxima de $147 \mathrm{~mm}$. Esses dados estão apresentados na Figura 5.5. Observa-se também 
nessa figura que houve um longo período de estiagem após as chuvas excepcionais do final de maio, que durou até o fim de agosto.

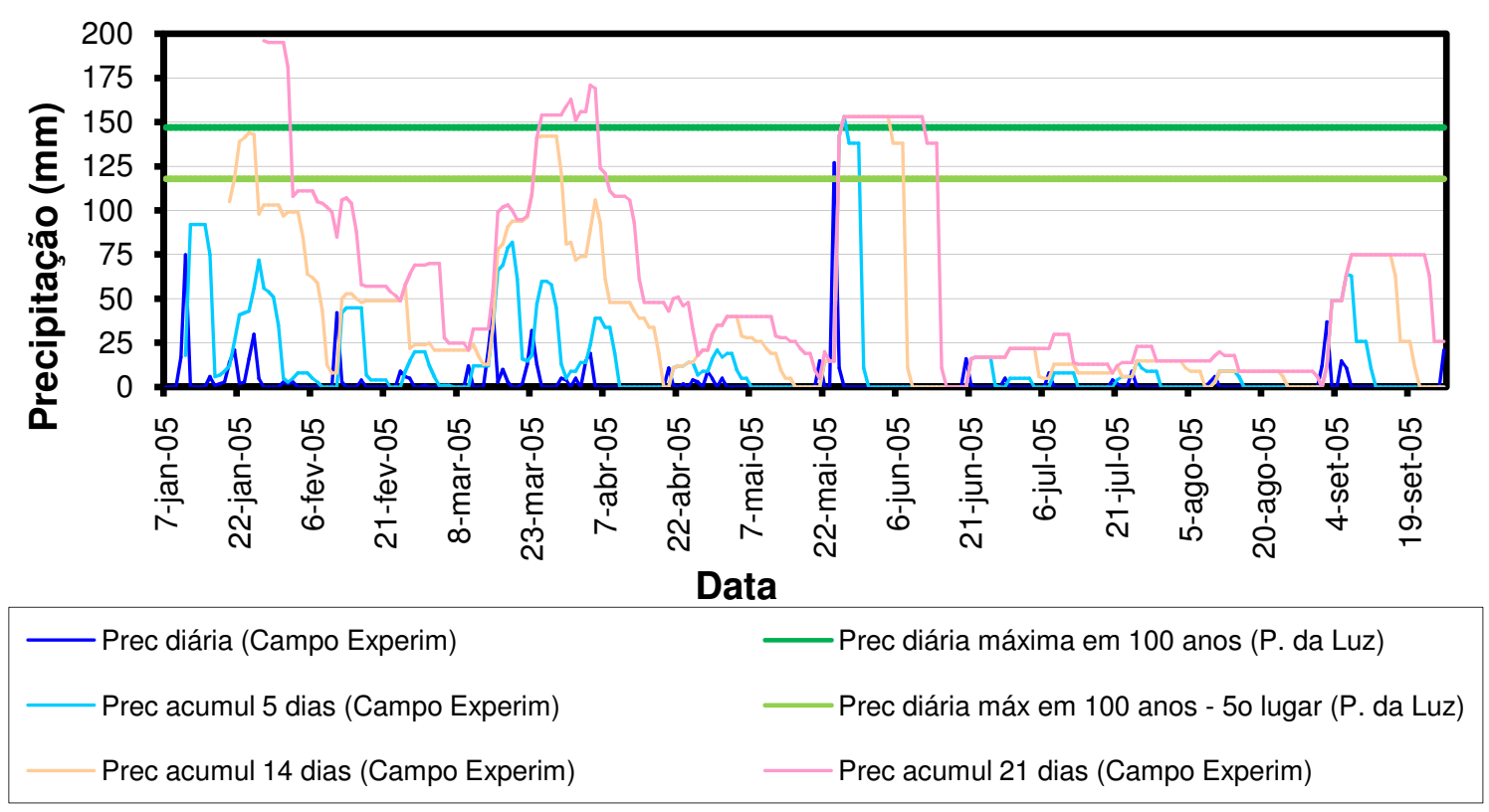

Figura 5.5: Pluviometria diária e acumulada em 5, 14 e 21 dias no campo experimental comparada com precipitações máximas no Posto da Luz

\subsection{Variação do nível d'água do terreno}

Há um córrego que passa a cerca de $25 \mathrm{~m}$ de distância do pé do talude, conforme pode ser visto nas Figuras 5.2 e 5.3. Nessas figuras são apresentadas linhas indicativas da superfície freática prevista em 07/01/2005. Considerando que a área estudada é uma cabeceira de drenagem onde o córrego nasce, constata-se que o nível d'água do córrego é abastecido pelo lençol freático do terreno.

As oscilações verificadas no nível d'água acompanharam as precipitações, conforme indicado na Figura 5.6. O nível d'água subiu durante períodos chuvosos e caiu quando as precipitações cessaram. 


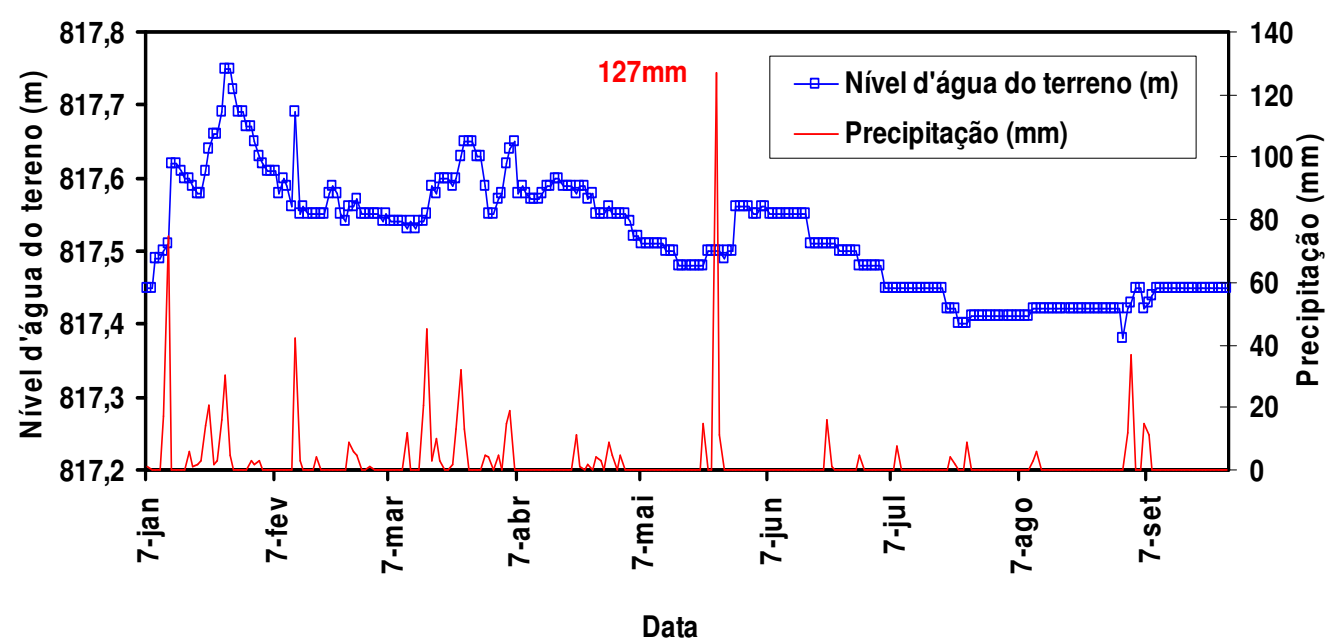

Figura 5.6: Relação entre o nível d'água e a precipitação

Considerando que um evento chuvoso corresponde a um número indeterminado de dias em que ocorrem precipitações intensas e de menor intensidade, até que ocorra um período prolongado de estiagem, apresenta-se a seguir uma correlação entre eventos chuvosos e elevação do nível d'água do terreno.

Os três principais eventos de chuva do período de estudo indicaram as seguintes precipitações e variações do nível d'água: a precipitação do dia 12 de janeiro, de $75 \mathrm{~mm}$, resultou em aumento de $11 \mathrm{~cm}$ no nível d'água; as chuvas que ocorreram entre os dias 17 de janeiro e 26 de janeiro somaram 98mm e resultaram em um aumento do nível d'água de $15 \mathrm{~cm}$; e as precipitações dos dias 15 de março a 25 de março de $142 \mathrm{~mm}$ elevaram o nível em $11 \mathrm{~cm}$.

A relação entre variação do nível d'água e precipitação acumulada para os três eventos acima, que ocorreram no período chuvoso do ano, foi de 1,$5 ; 1,5$ e 0,8 ; respectivamente. As relações maiores que 1,0 indicam que o nível d'água teve variação maior que a altura de chuva do período. Esse parâmetro pode fornecer uma idéia de grandeza da variação do NA no maciço estudado, em solo residual silto-arenoso, durante um evento chuvoso. 
Verificou-se também que a elevação do nível d'água ocorreu em média dois dias após a ocorrência de precipitação intensa. Como exemplo cita-se o dia 11 de janeiro quando choveu $75 \mathrm{~mm}$, e 2 dias depois o nível subiu $11 \mathrm{~cm}$; e o dia 15 de março quando choveu $45 \mathrm{~mm}$ e dois dias depois o NA subiu $4 \mathrm{~cm}$.

Exceção ocorreu em 24 de maio, período de estiagem, quando houve precipitação de $127 \mathrm{~mm}$ e o nível d'água do terreno manteve-se estável durante 5 dias, e no sexto dia elevou-se em $6 \mathbf{c m}$. Pode-se explicar o fato do nível d'água ter levado maior tempo para ter menor elevação, considerando que o solo se encontrava com menor umidade em 24 de maio, período de estiagem, portanto com menor permeabilidade, contribuindo para um fluxo mais lento e maior tempo para a elevação do nível d'água. A menor elevação do NA em relação a outras datas citadas pode ser explicada por dois fatores: menor infiltração de água, durante a precipitação, na superfície do terreno, mais seco e com menor permeabilidade; e maior retenção de água nos vazios do solo mais seco.

Durante o período de monitoramento o nível d'água variou apenas $37 \mathrm{~cm}$. Atingiu cota máxima $817,75 \mathrm{~m}$ no dia 26 de janeiro e cota mínima $817,38 \mathrm{~m}$ em $1^{\circ}$ de setembro. A distância do NA até o pé do talude variou de 2,97 m a 2,60 m na porção argamassada do talude, e de $3,77 \mathrm{~m}$ a 3,40 m na porção com vegetação do talude. A cota do pé do talude na porção argamassada do talude é $820,35 \mathrm{~m}$, abaixo da cota do pé do talude na porção vegetada, $821,15 \mathrm{~m}$.

A pequena variação do nível freático registrada no talude experimental pode ser explicada em parte pela camada de argila, de baixa permeabilidade, existente sobre o solo residual siltoso em uma extensa área no entorno do campo experimental, que impede a passagem de um fluxo significativo de água de chuva para o interior do maciço. Destaca-se que seu coeficiente de permeabilidade, $2,2 \times 10^{-7} \mathrm{~cm} / \mathrm{s}$, corresponde em outra unidade a 0,06 m/ano e que para um gradiente igual a 1,0 o fluxo (saturado) anual por $\mathrm{m}^{2}$ seria de apenas $0,06 \mathrm{~m}^{3}$. 
A melhor relação entre a variação e do nível d'água e a precipitação acumulada, durante o período de monitoramento, foi obtida com a pluviometria acumulada de 20 dias até 3 dias antes da data, conforme é apresentado na Figura 5.7.

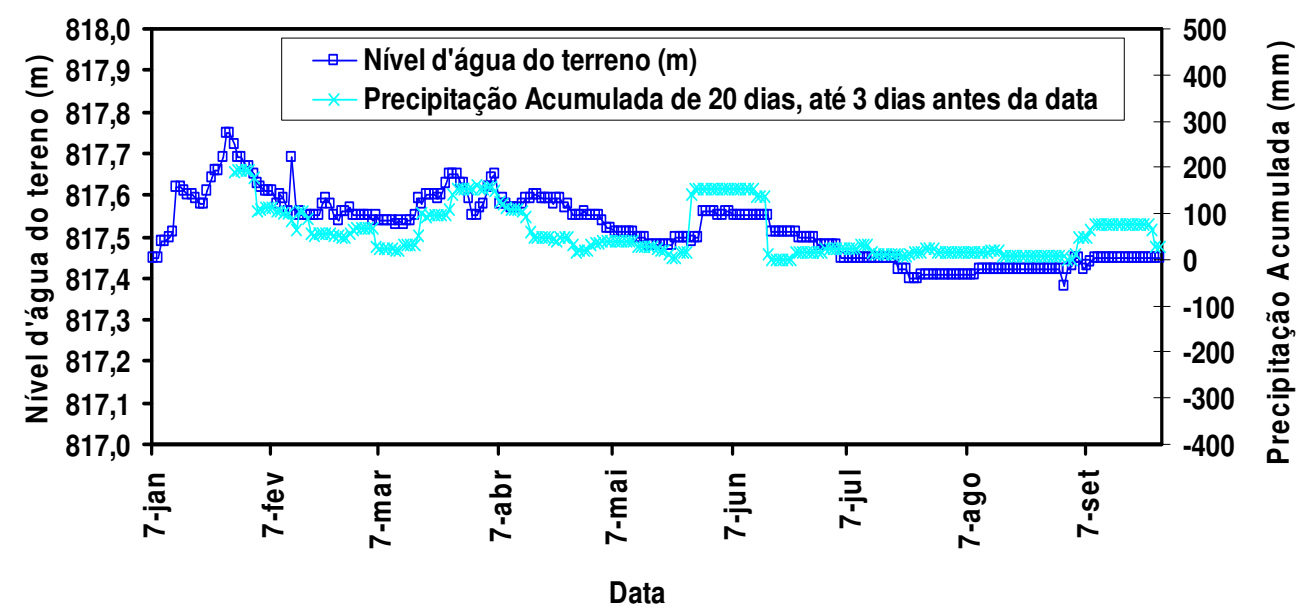

Figura 5.7: Relação entre o nível d'água e a precipitação acumulada de 20 dias, até 3 dias antes da data

Correlacionando-se o nível d'água com a precipitação acumulada de 20 dias até 3 dias antes da data, para todos os dias do período de monitoramento em que foi possível fazer a correlação, encontrou-se a equação indicada na Figura 5.8.

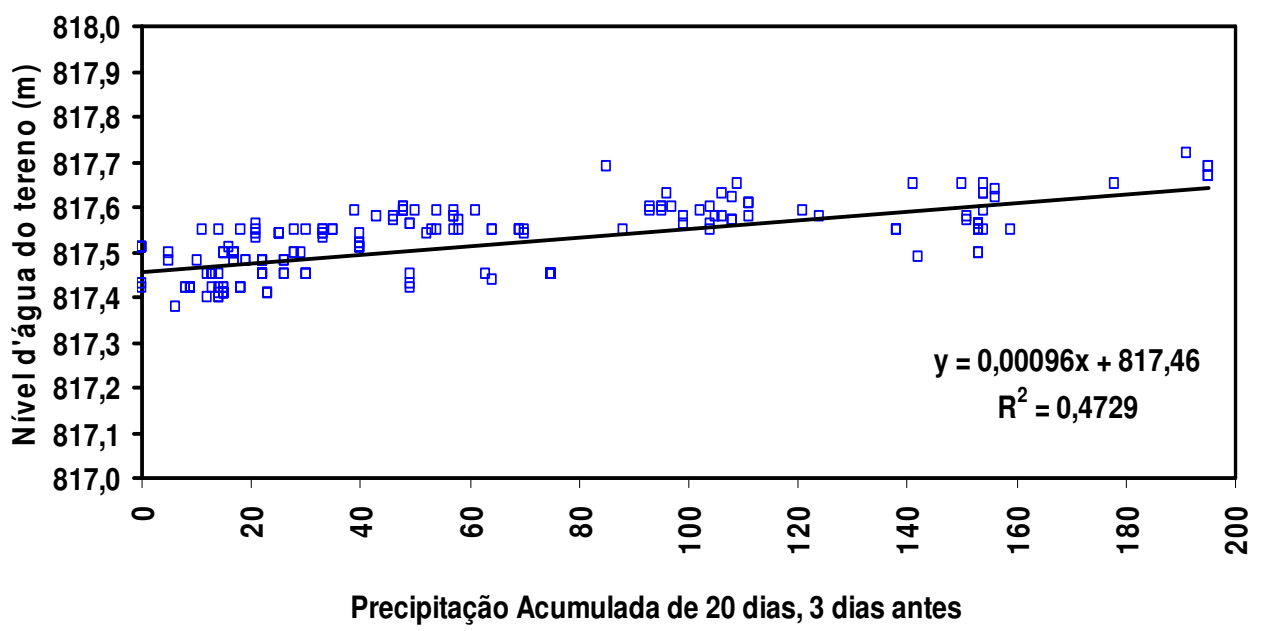

Figura 5.8: Correlação entre o nível d'água e a precipitação acumulada de 20 dias, até 3 dias antes da data 


\subsection{Resposta hidrológica do talude}

Apresenta-se a seguir a resposta hidrológica do talude experimental no período de monitoramento. Serão comparadas as leituras de poro-pressão de água na porção do talude com vegetação com as leituras na porção com revestimento em argamassa, objetivando estudar o efeito do revestimento superficial no fluxo não saturado.

Esse estudo levará em consideração que o solo superficial nas linhas 1, 2 e 3 do talude é o aterro argiloso, e que nas linhas 4 e 5 é o solo residual siltoso. Portanto, as análises do efeito do revestimento superficial no fluxo não saturado e, por conseguinte na variação das poro-pressões de água no solo serão feitas em separado para cada tipo de solo superficial. Apresenta-se na Tabela 5.2 os coeficientes de permeabilidade dos materiais envolvidos no fluxo e pontos de entrada de ar.

Tabela 5.2: Características hidráulicas dos materiais onde ocorre fluxo em $\mathrm{cm} / \mathrm{s}$

\begin{tabular}{|l|l|l|l|l|l|}
\hline Material & $\begin{array}{l}\mathrm{k}_{\text {ver }} \\
(\text { Labor })\end{array}$ & $\begin{array}{l}\mathrm{K}_{\text {hor }} \\
(\text { Labor })\end{array}$ & $\begin{array}{l}\mathrm{K}_{45}{ }^{0} \\
(\text { Labor })\end{array}$ & $\begin{array}{l}\mathrm{k}_{\text {guelph }} \\
(\text { Campo })\end{array}$ & $\begin{array}{l}\text { Ponto Entrada } \\
\text { de } \operatorname{Ar}(\mathrm{kPa})\end{array}$ \\
\hline Aterro Argiloso & $2,2 \cdot 10^{-7}$ & $2,5 \cdot 10^{-6}$ & - & $2,0 \cdot 10^{-7}$ & 150 \\
\hline Argamassa & $2,8 \cdot 10^{-6}$ & - & - & - & - \\
\hline Solo Res.Siltoso & $1,2 \cdot 10^{-4}$ & $9,0 \cdot 10^{-5}$ & $4,5 \cdot 10^{-4}$ & $2,0 \cdot 10^{-4}$ & 4 \\
\hline
\end{tabular}

O coeficiente de permeabilidade da argamassa de revestimento é maior que o do aterro argiloso, e o coeficiente de permeabilidade do solo residual siltoso é maior que $\mathrm{o}$ da argamassa. Espera-se que a argamassa tenha um efeito redutor na infiltração de água de chuva no solo residual siltoso, e que não afete de forma significativa a infiltração no aterro argiloso.

Os coeficientes de permeabilidade apresentados acima não levam em consideração o efeito do sistema radicular do capim que recobre a porção do talude com vegetação. Esse sistema tende a reduzir a permeabilidade do solo nu, em que foram medidos os coeficientes de permeabilidade em campo e em laboratório. 
O valor de entrada de ar do aterro argiloso é elevado, $150 \mathrm{kPa}$, podendo indicar que esse solo poderá estar saturado na maior parte do ano, o mesmo não ocorre com o solo residual porque seu valor de entrada de ar é $4 \mathrm{kPa}$.

A análise das cerca de 1.600 leituras de poro-pressão de água no talude realizadas durante o período experimental será apresentada de três formas:

(a) por meio de séries temporais de poro-pressões de água, durante o período de estudo, nas porções argamassada e com vegetação em uma mesma profundidade e região do talude;

(b) por meio de perfis de poro-pressão de água em que se pode visualizar o avanço de frentes de umedecimento ou secagem ao longo do tempo;

(c) por meio de seções transversais do talude com indicação da distribuição de poropressões de água em datas selecionadas.

\subsubsection{Série temporal de poro-pressões de água e precipitações}

As leituras fornecidas pelos tensiômetros instalados ao longo do talude, em suas 5 linhas e três profundidades, são apresentadas duas a duas, comparando-se o comportamento nas porções revestidas com argamassa e com vegetação. Juntamente com esses dados são apresentadas as leituras de precipitação.

Não serão apresentados os resultados de medições de poro-pressão de água entre 25 de fevereiro e oito de abril, pois o tensímetro analógico utilizado apresentou leituras incoerentes.

Na linha 1 a 0,5 $\mathrm{m}$ de profundidade, até o mês de abril, as leituras em ambas as porções do talude mantiveram-se próximas, em um patamar entre 0 e $-10 \mathrm{kPa}$. Durante o período seco do ano as poro-pressões de água decresceram substantivamente na porção com vegetação atingindo $-64 \mathrm{kPa}$ em 26 de julho em 
comparação com -10 kPa na porção com argamassa (Fig. 5.9-A). Os dados indicam, provavelmente, que a vegetação teve importante papel na redução de umidade do solo por meio de evapo-transpiração.

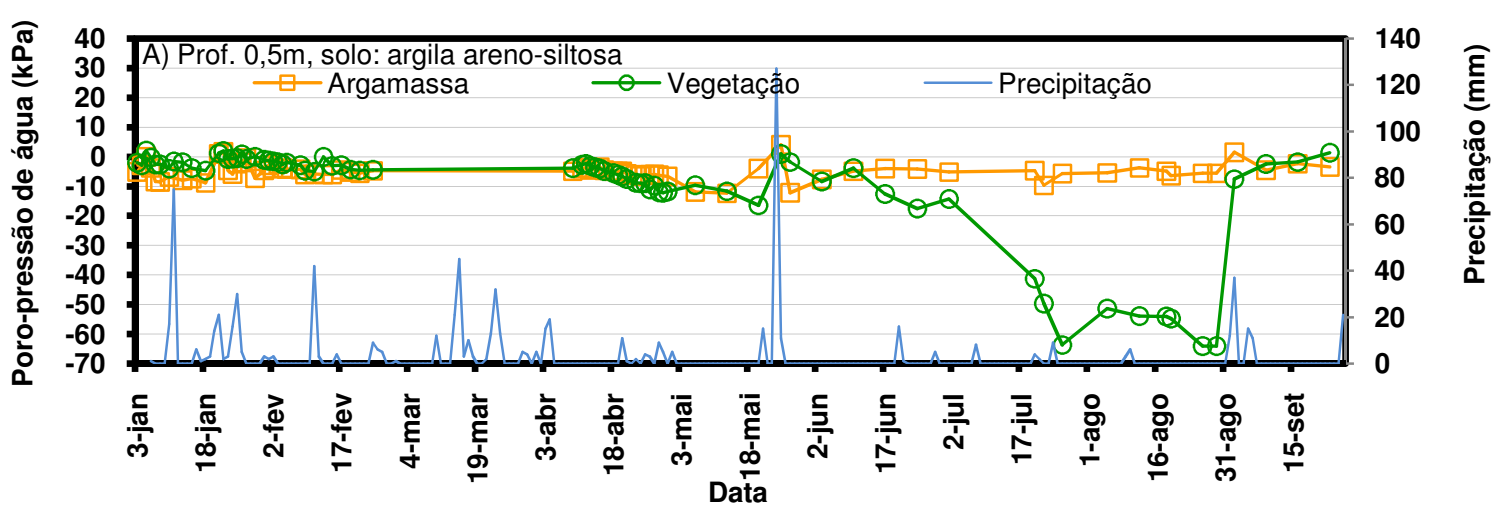

Figura 5.9-A): Série temporal de poro-pressão de água e precipitação na Linha 1 em ambos os revestimentos superficiais na profundidade de $0,5 \mathrm{~m}$

Em 25 de maio as poro-pressões de água a $1,5 \mathrm{~m}$ de profundidade na porção com revestimento em argamassa elevaram-se a 13,4 kPa (Fig. 5.10-B), próximo da pressão hidrostática, como decorrência das fortes chuvas $(127 \mathrm{~mm})$ ocorridas no dia anterior. Na porção do talude com vegetação o valor registrado foi $6,0 \mathrm{kPa}$, menor que na porção com argamassa. Esse resultado pode ter sido influenciado pelo momento em que foram feitas as leituras, e portanto não se pode saber se foram as poro-pressões máximas nessa profundidade. Destaca-se que as poro-pressões passaram a valores positivos na manhã seguinte ao evento chuvoso, indicando variação "rápida" de poro-pressão de água, com reduzido intervalo de tempo entre precipitação e a variação de poro-pressão de água.

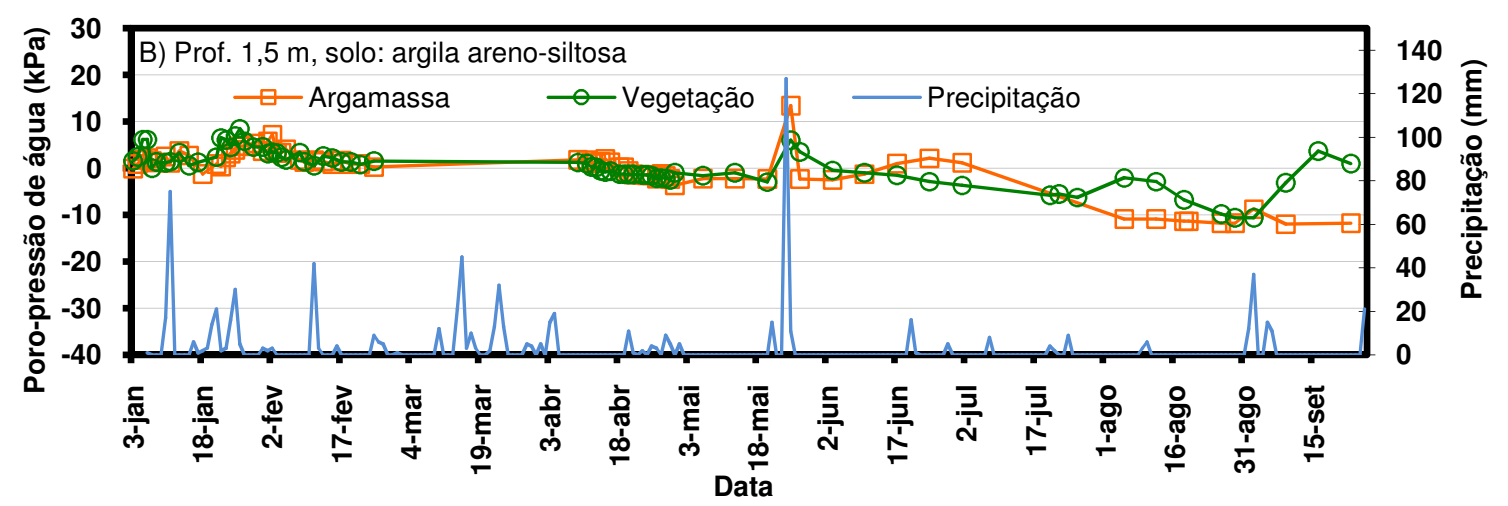

Figura 5.10-B): Série temporal de poro-pressão de água e precipitação na Linha 1 em ambos os revestimentos superficiais na profundidade de $1,5 \mathrm{~m}$ 
As medições de poro-pressão de água a 4,0 $\mathrm{m}$ de profundidade na porção com vegetação foram feitas com um tubo tensiométrico instalado com um ângulo de $20^{\circ}$ com a horizontal (indicado na Fig. 5.3), diferentemente dos demais tubos que foram instalados na vertical. A pedra porosa do tubo foi instalada próximo do contato entre 0 aterro argiloso e o solo residual siltoso. As leituras nesse tubo indicaram pequena variação durante o ano, entre 5 e $-10 \mathrm{kPa}$ (Fig. 5.11-C), podendo indicar algum defeito de funcionamento.

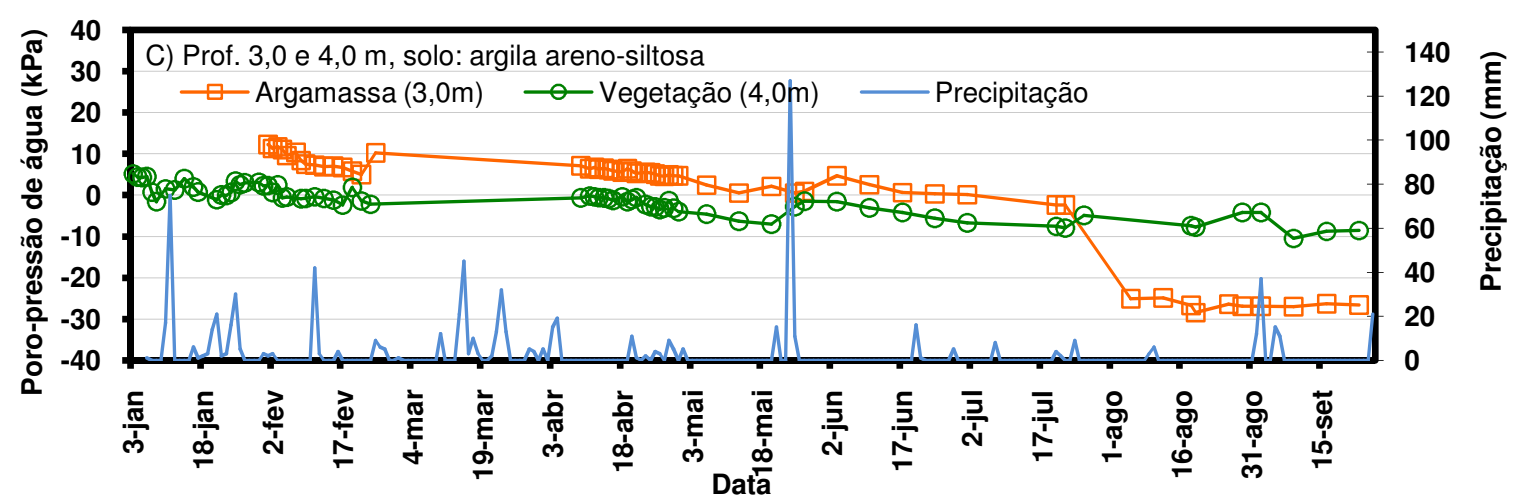

Figura 5.11-C): Série temporal de poro-pressão de água e precipitação na Linha 1 em ambos os revestimentos superficiais nas profundidades de 3,0 e 4,0 m

Entre julho e setembro as poro-pressões na linha 2 a 1,5 $\mathrm{m}$ de profundidade com revestimento em vegetação caíram de -10 para $-30 \mathrm{kPa}$ (Fig. 5.12-A) em função da redução das chuvas, o que não ocorreu com a porção revestida com argamassa. Conforme observado anteriormente a vegetação pode ter provocado essa diferença de comportamento por meio da evapo-transpiração.

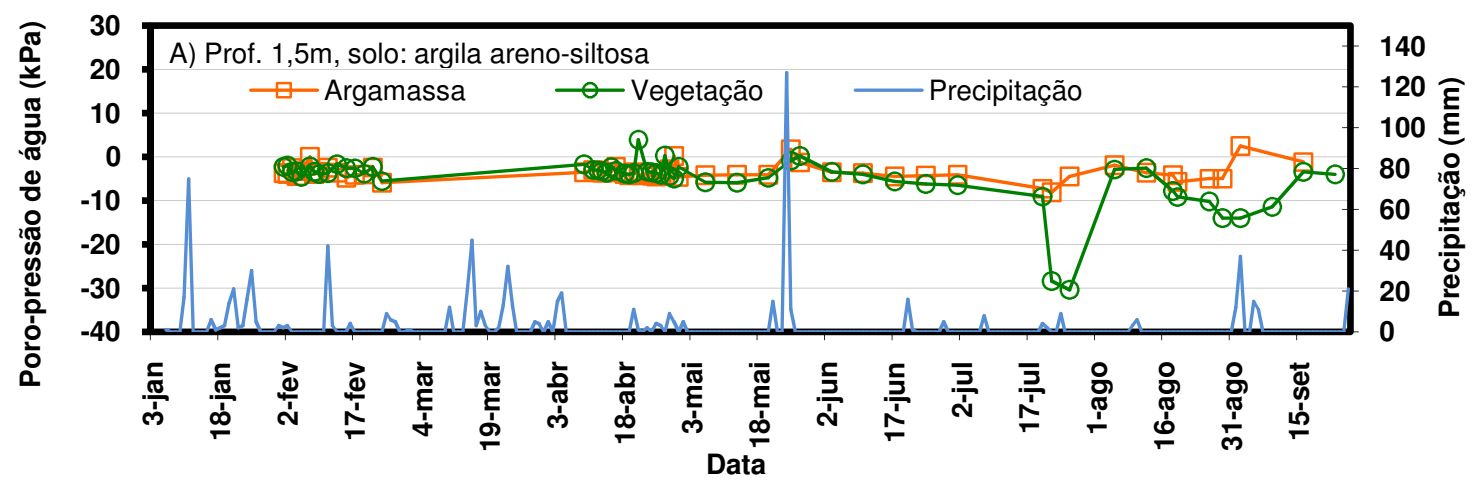

Figura 5.12-A): Série temporal de poro-pressão de água e precipitação na Linha 2 em ambos os revestimentos superficiais na profundidade de $1,5 \mathrm{~m}$ 
$\mathrm{Na}$ linha 2 a 3,0 $\mathrm{m}$ de profundidade (Fig. 5.13-B) até a metade do período do experimento a porção com vegetação e silte areno-argiloso registrou poro-pressões de água maiores que a porção argamassada e argila areno-siltosa. Seria de se esperar que ocorresse o contrário, em função das curvas de retenção dos solos. Não foi determinada a causa desse comportamento. É um aspecto que fica para ser examinado.

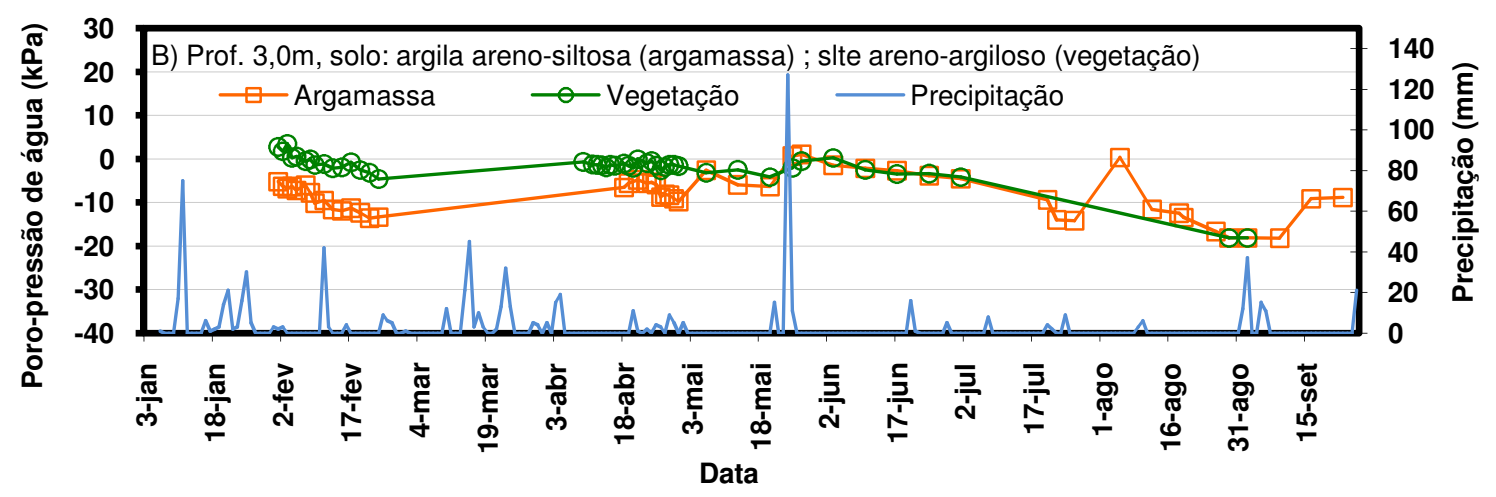

Figura 5.13-B): Série temporal de poro-pressão de água e precipitação na Linha 2 em ambos os revestimentos superficiais na profundidade de $3,0 \mathrm{~m}$

$\mathrm{Na}$ linha 3 a 0,5 m de profundidade (Fig. 5.14-A), destaca-se o comportamento diferenciado dos revestimentos em relação aos períodos chuvosos e de estiagem. Isto é, nos períodos chuvosos a porção revestida com argamassa apresentou menores poro-pressões de água do que a porção com vegetação, o que pode indicar que a argamassa reduziu a infiltração de água de chuva, em relação à porção com vegetação.

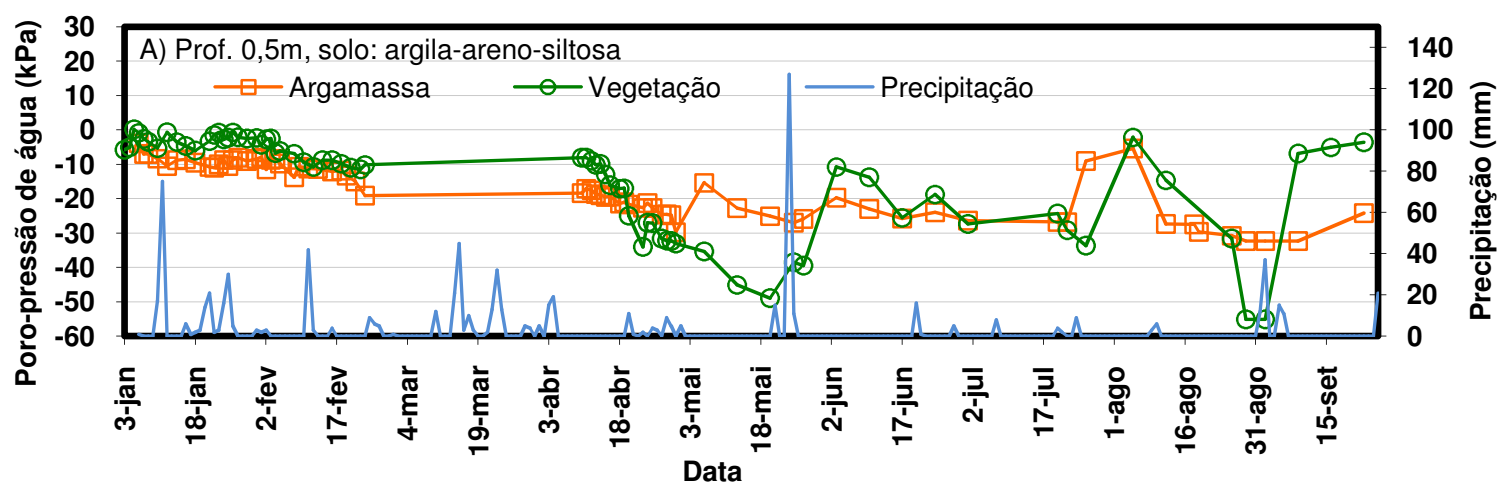

Figura 5.14-A): Série temporal de poro-pressão de água e precipitação na Linha 3 em ambos os revestimentos superficiais na profundidade de $0,5 \mathrm{~m}$ 
E nos períodos de estiagem, a porção argamassada apresentou maiores poropressões de água que a porção com vegetação, indicando que a vegetação retirou água do solo por meio de evapo-transpiração. Esse comportamento também pode ser observado nas demais profundidades monitoradas, 1,5 m (Fig. 5.15-B) e 3,0 m (Fig. 5.16-C), desta linha.

$\mathrm{Na}$ linha 3 a $1,5 \mathrm{~m}$ de profundidade (Fig. 5.15-B), com presença de argila arenosiltosa, a porção argamassada do talude registrou poro-pressões de água menores que a porção com vegetação (aproximadamente $10 \mathrm{kPa}$ ), ao longo de todo o ano.

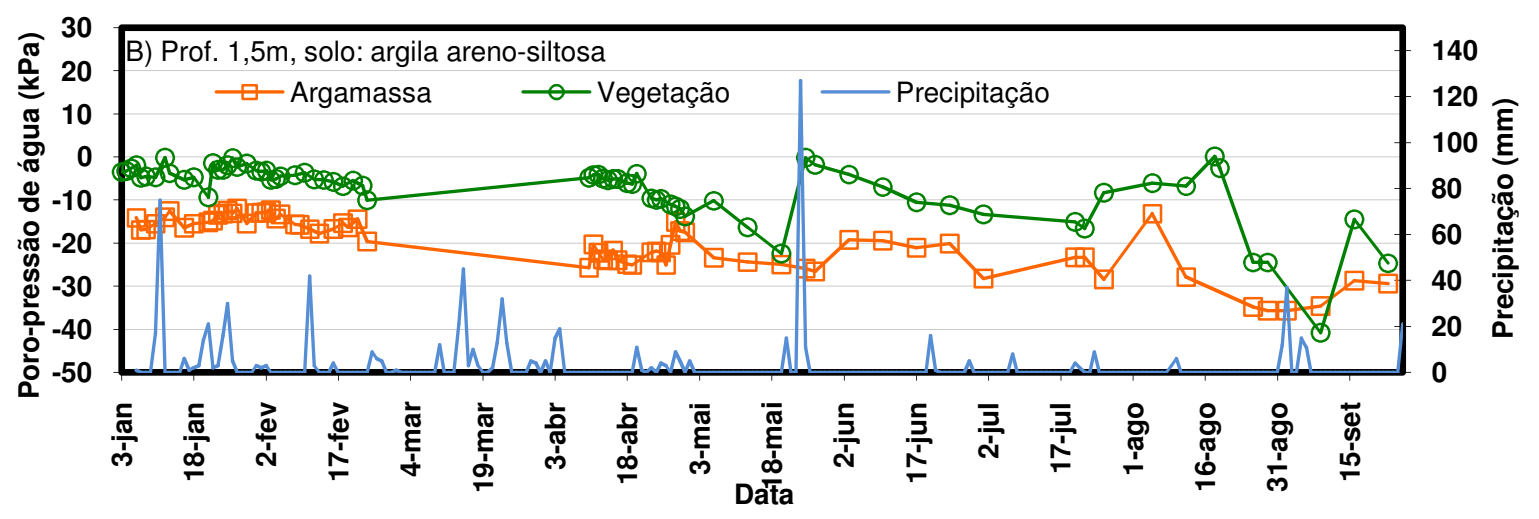

Figura 5.15-B): Série temporal de poro-pressão de água e precipitação na Linha 3 em ambos os revestimentos superficiais na profundidade de $1,5 \mathrm{~m}$

No evento chuvoso de 25 de maio, quando houve precipitação de $127 \mathrm{~mm}$, as poropressões de água mantiveram-se estáveis na porção argamassada do talude, nas três profundidades monitoradas da linha 3 . E a porção com vegetação apresentou elevação das poro-pressões de água nas três profundidades, chegando a atingir 12 $\mathrm{kPa}$ (positivo) na profundidade de 3,0 m (Fig. 5.16-C). 


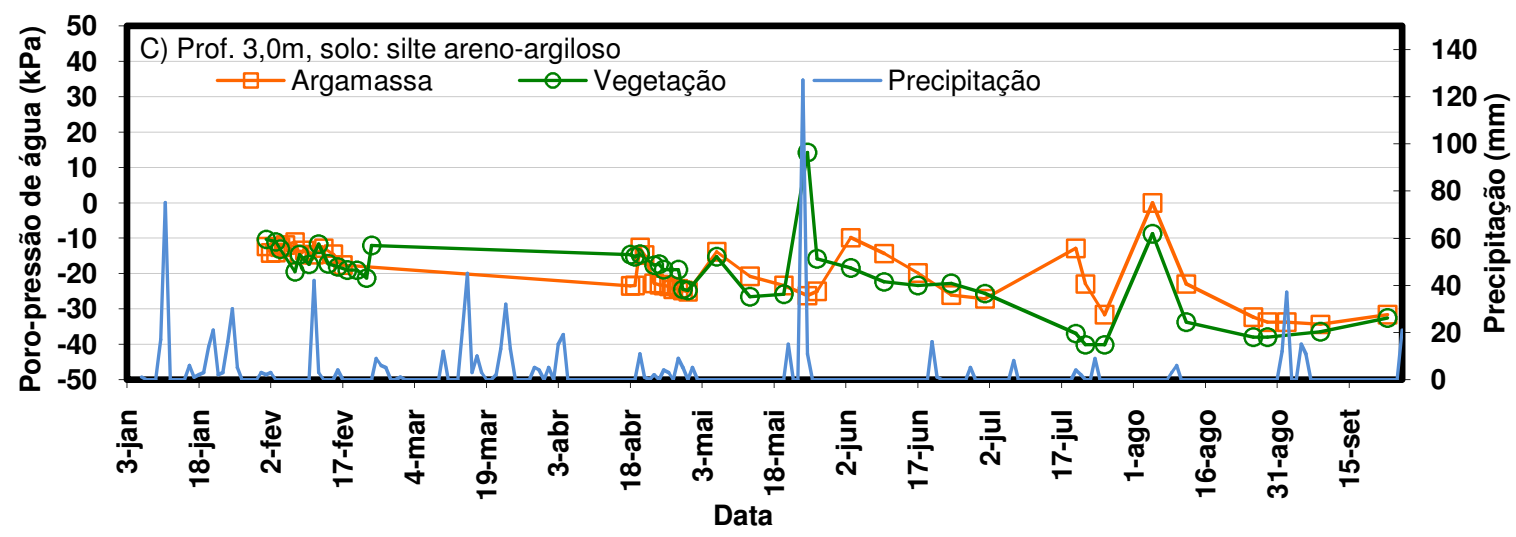

Figura 5.16-C): Série temporal de poro-pressão de água e precipitação na Linha 3 em ambos os revestimentos superficiais na profundidade de $3,0 \mathrm{~m}$

Os resultados do monitoramento da linha 4 (Figs. 5.17-A e 5.18-B) na porção com vegetação são similares aos da porção argamassada.

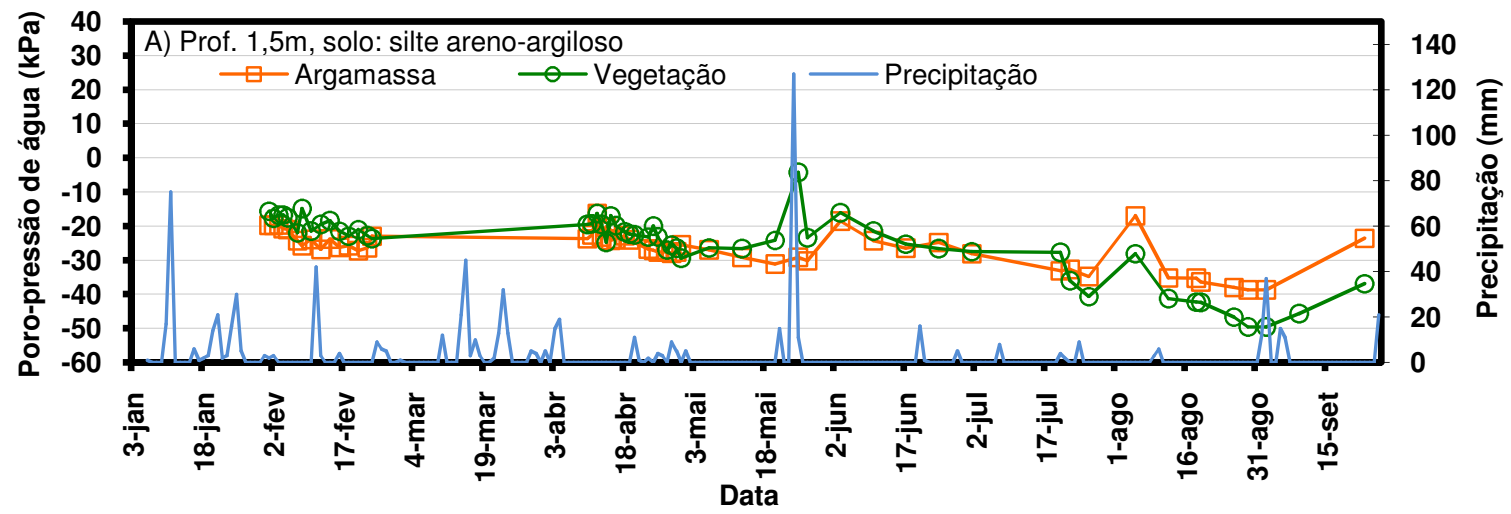

Figura 5.17-A): Série temporal de poro-pressão de água e precipitação na Linha 4 em ambos os revestimentos superficiais na profundidade de $1,5 \mathrm{~m}$

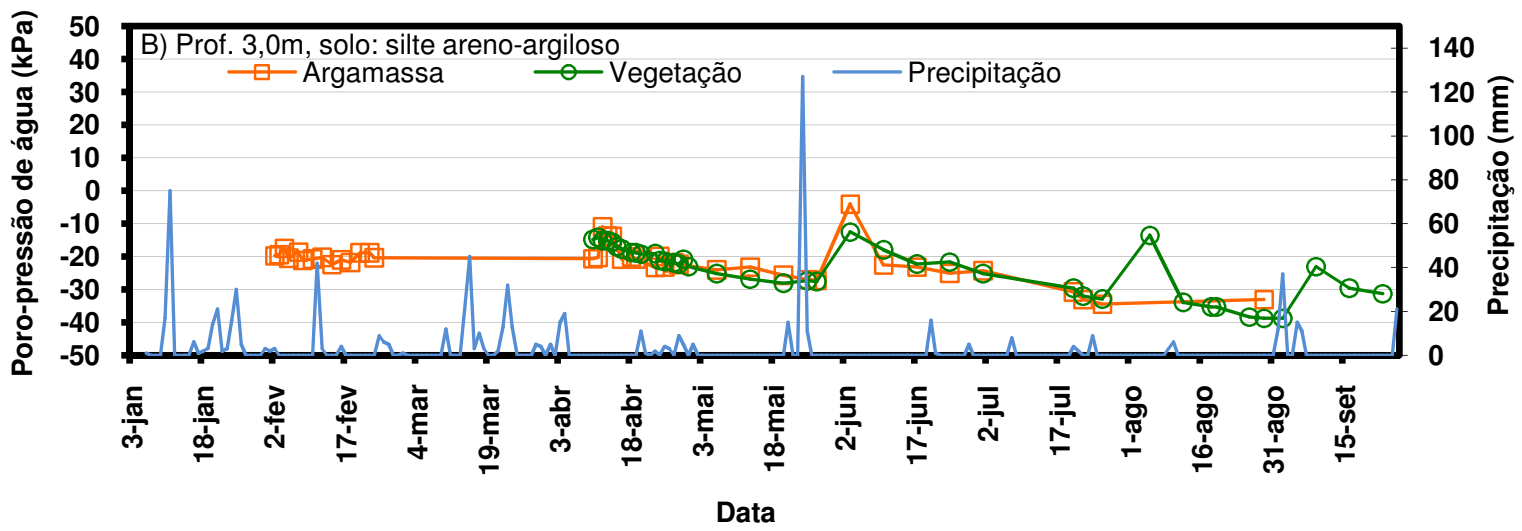

Figura 5.18-B): Série temporal de poro-pressão de água e precipitação na Linha 4 em ambos os revestimentos superficiais na profundidade de $3,0 \mathrm{~m}$ 
Os tensiômetros instalados na porção revestida com argamassa da linha 5 encontram-se instalados em cota inferior aos instalados na porção com vegetação, $0,8 \mathrm{~m}$ abaixo. Aqueles tensiômetros estão mais próximos do nível d'água do terreno e apresentam leituras cerca de $10 \mathrm{kPa}$ maiores (Figs. 5.19-A e 5.20-B), provavelmente influenciados pela proximidade do nível d’água.

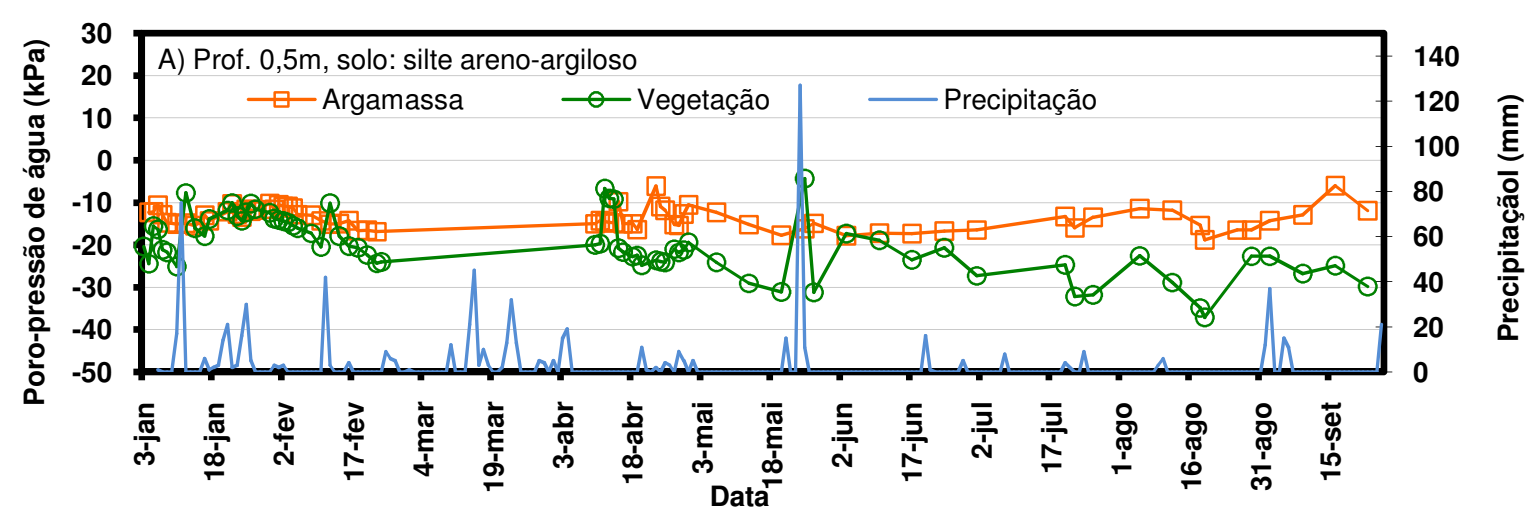

Figura 5.19-A): Série temporal de poro-pressão de água e precipitação na Linha 5 em ambos os revestimentos superficiais na profundidade de $0,5 \mathrm{~m}$

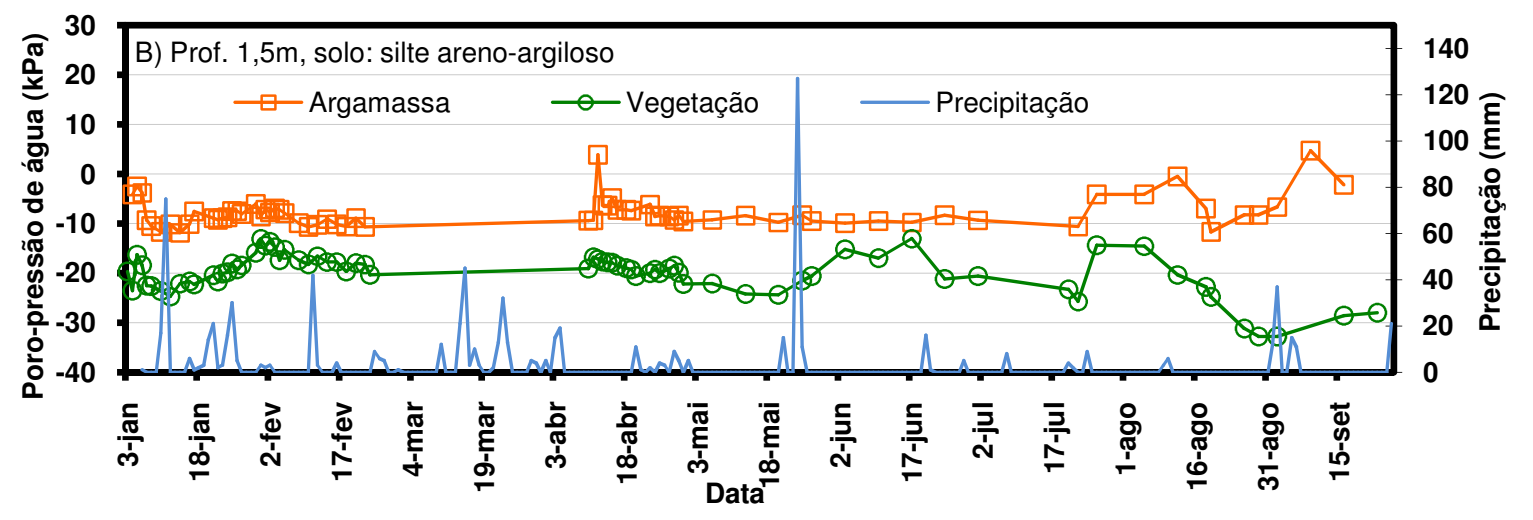

Figura 5.20-B): Série temporal de poro-pressão de água e precipitação na Linha 5 em ambos os revestimentos superficiais na profundidade de $1,5 \mathrm{~m}$

De maneira geral os tensiômetros na área experimental apresentaram resultados coerentes, registraram elevação de poro-pressão de água nos dias chuvosos ou nos dias subseqüentes aos dias chuvosos, e redução ou manutenção de poro-pressões de água nos períodos de estiagem. 
Há uma tendência de nos períodos secos do ano ocorrer maior redução de poropressão de água na porção com vegetação do que na porção argamassada do talude. Provavelmente devido ao efeito da evapo-transpiração realizada pela vegetação. Há uma tendência de nos períodos de chuvas intensas a argamassa reduzir a infiltração de água no solo, ou aumentar o "run-off", e manter a poropressão de água menor nesta região do que na porção com vegetação.

\subsubsection{Perfis de poro-pressão de água}

Os perfis de poro-pressão de água permitem a visualização das frentes de umedecimento e secagem do solo durante períodos chuvosos e de estiagem. Por meio dos perfis serão comparados os comportamentos dos tipos de revestimento superficial do talude e dos tipos de solos existentes.

Análises a seguir serão comparadas com os resultados obtidos anteriormente neste trabalho a fim de se confirmar as tendências de menores poro-pressões de água no silte do que na argila, e menores poro-pressões de água na porção com vegetação do que na porção argamassada nos períodos de estiagem, e maiores poro-pressões de água na porção com vegetação do que na porção argamassada nos períodos de chuvas intensas.

\subsubsection{Período de estiagem}

Os perfis de poro-pressões de água apresentados a seguir indicaram o avanço de frente de secagem no período de 10 de junho a 26 de julho. Período de estiagem em que houve poucos dias com chuva e de pequena intensidade. As precipitações que ocorreram no período foram: $16 \mathrm{~mm}$ em 20/06; $5 \mathrm{~mm}$ em 28/06; $8 \mathrm{~mm}$ em 07/07; 4 $\mathrm{mm}$ em 20/07; $2 \mathrm{~mm}$ em 21/07; e $9 \mathrm{~mm}$ em 24/07, conforme pode ser verificado na Figura 5.6. Essas precipitações totalizaram $47 \mathrm{~mm}$, e a precipitação média do período foi de $1,3 \mathrm{~mm}$ por dia. 
Para a elaboração dos perfis foram utilizadas as leituras de poro-pressão de água na Linha 1 com profundidades de 0,5 m e 1,5 m, e solo argiloso; e na Linha 4 com profundidades de $1,5 \mathrm{~m}$ e 3,0 $\mathrm{m}$ e na Linha $5 \mathrm{com}$ profundidade de $0,5 \mathrm{~m}$, onde há solo siltoso, que podem ser vistos, em planta, na Figura 3.13, e em seções, nas Figuras 3.14 e 3.15 .

\section{Comparação entre revestimentos}

Nas Figuras 5.21 e 5.22 são apresentados os avanços das frentes de secagem nas porções do talude revestidas em vegetação e argamassa, respectivamente, ambas em solo argiloso. Observa-se que a $0,5 \mathrm{~m}$ de profundidade as poro-pressões de água reduziram-se significativamente na porção com vegetação, $59 \mathrm{kPa}$, de $-3,9 \mathrm{kPa}$ para $-63,3 \mathrm{kPa}$, e praticamente não se alterou na porção argamassada. $\mathrm{Na}$ profundidade de $1,5 \mathrm{~m}$ a variação em ambas as porções do talude foi pequena.

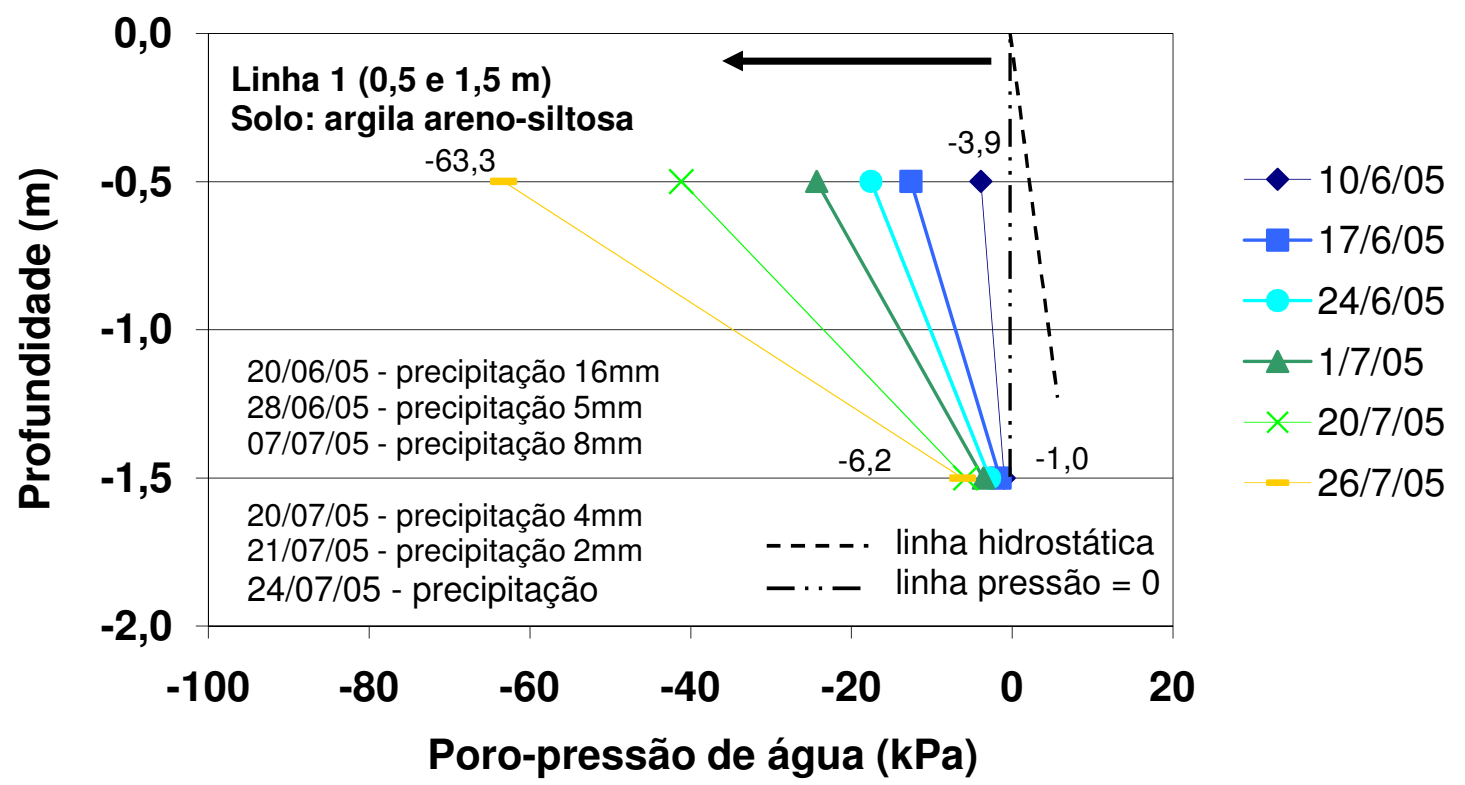

Figura 5.21: Perfis de poro-pressão de água durante estiagem de 10 de junho a 26 de julho, em área com solo argiloso e revestimento superficial em vegetação 


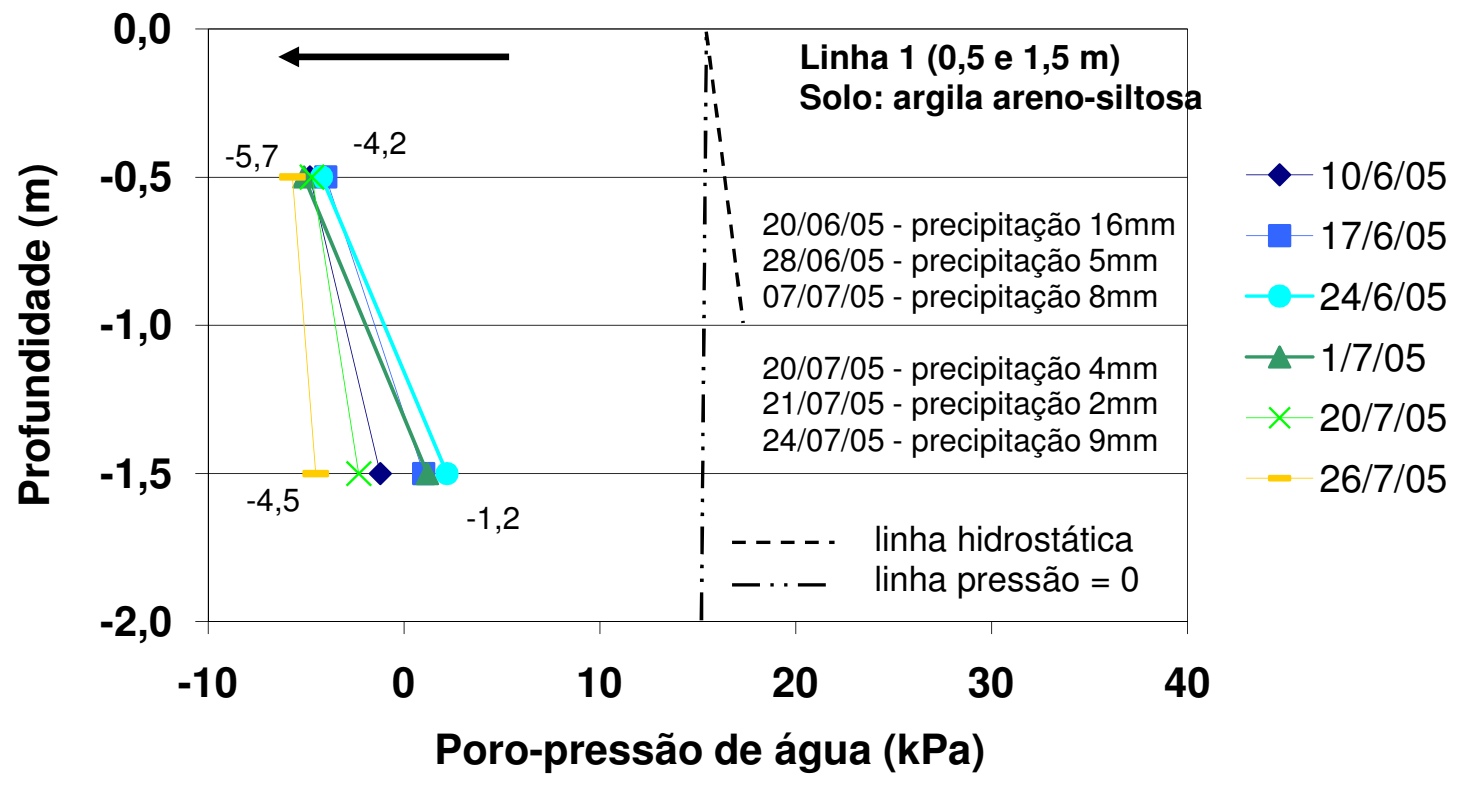

Figura 5.22: Perfis de poro-pressão de água durante a estiagem de 10 de junho a 26 de julho, em área com solo argiloso e revestimento superficial em argamassa

Nas Figuras 5.23 e 5.24 são apresentados os avanços das frentes de secagem nas porções do talude revestidas em vegetação e argamassa, respectivamente, ambas em solo siltoso.

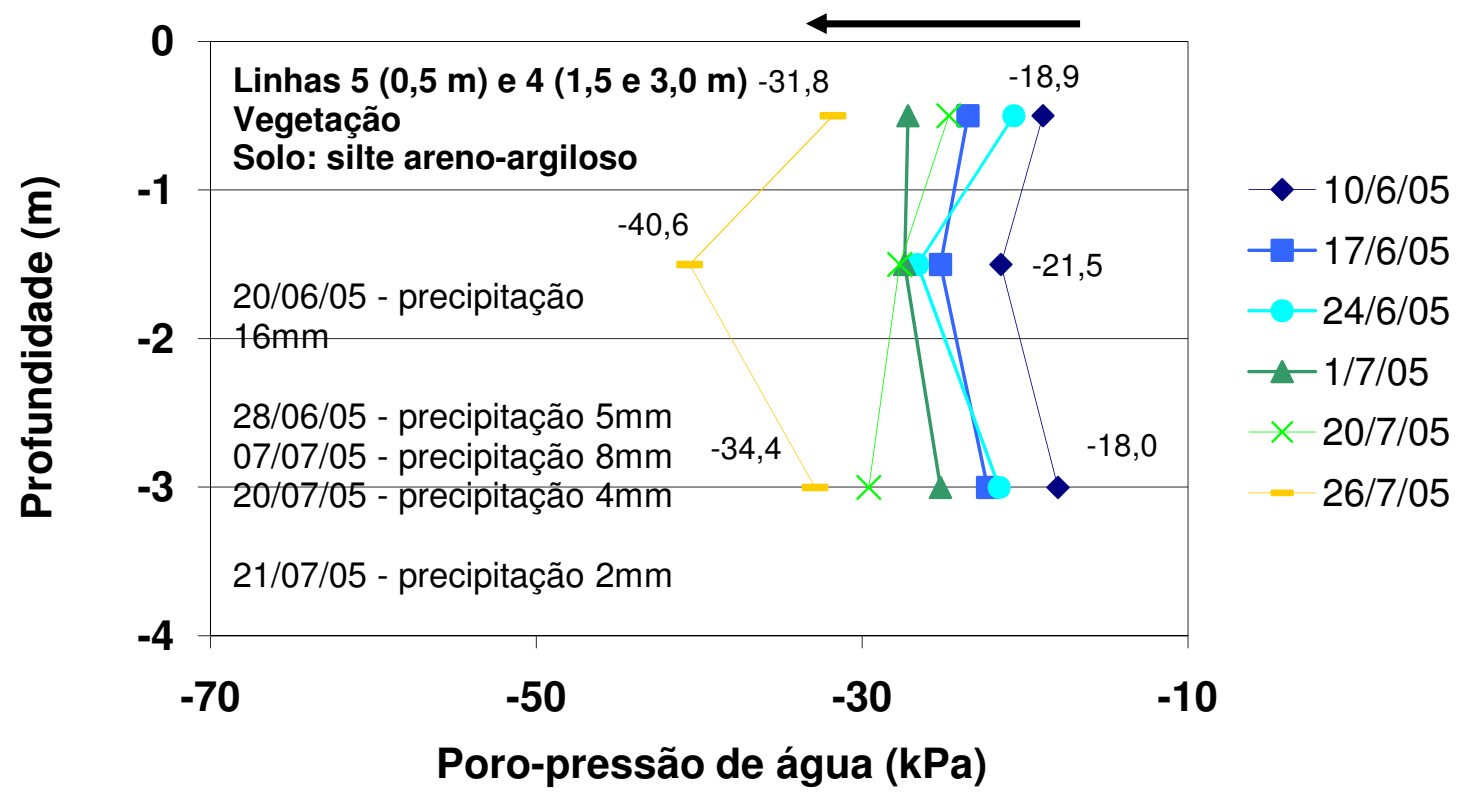

Figura 5. 23: Perfis de poro-pressão de água durante estiagem de 10 de junho a 26 de julho, em área com solo siltoso e revestimento superficial em vegetação 


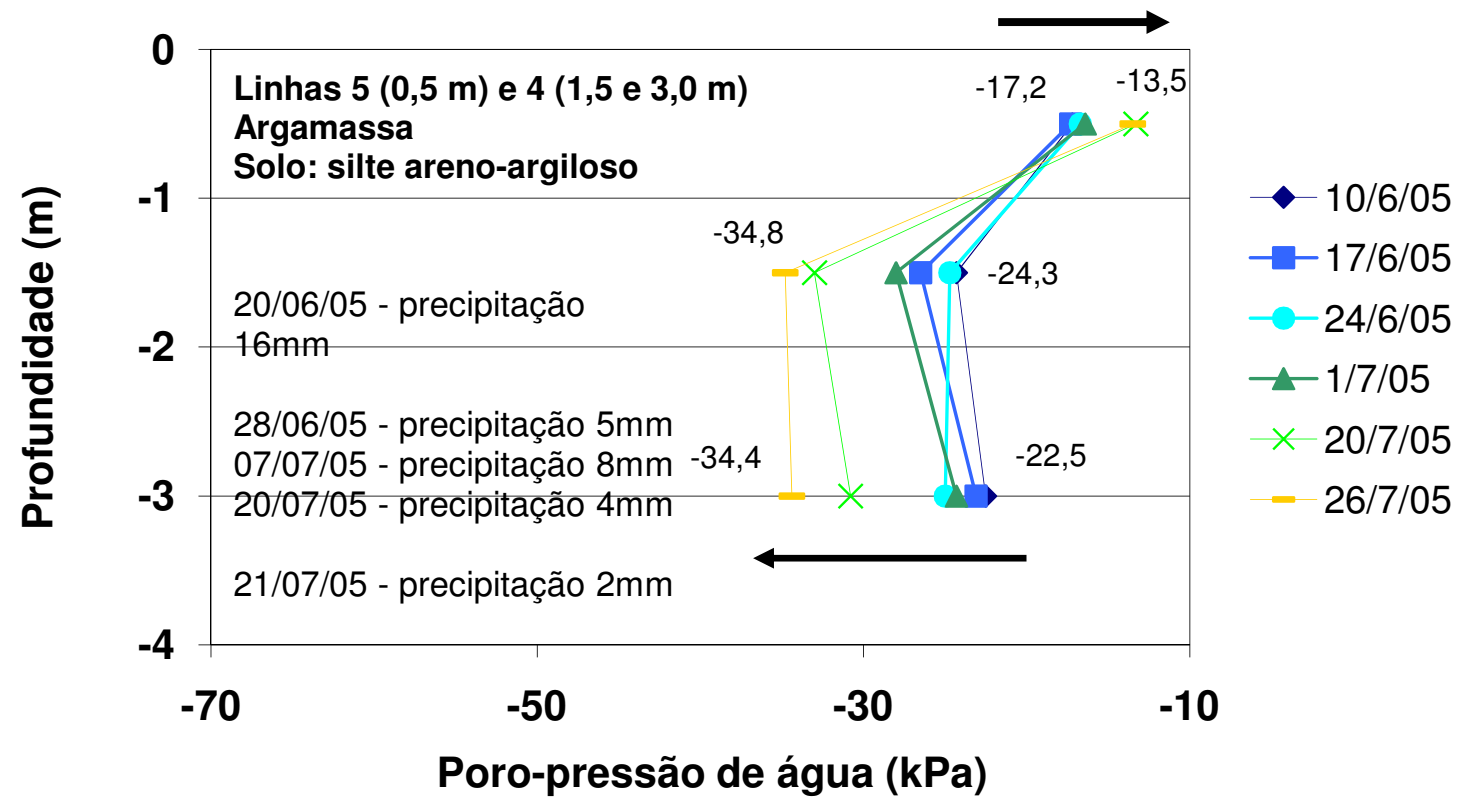

Figura 5. 24: Perfis de poro-pressão de água durante a estiagem de 10 de junho a 26 de julho, em área com solo siltoso e revestimento superficial em argamassa

Observa-se que a 0,5 $\mathrm{m}$ de profundidade as poro-pressões de água reduziram-se na porção com vegetação $(12 \mathrm{kPa})$ e praticamente não se alteraram na porção argamassada. A 1,5 $\mathrm{m}$ de profundidade as reduções de poro-pressão foram maiores na porção vegetada (19 Kpa) do que na porção revestida de argamassa (11 kPa), assim como na profundidade de 3,0 m, com redução de $16 \mathrm{kPa}$ na área vegetada contra $11 \mathrm{kPa}$ na argamassada.

Verificou-se uma tendência da porção com vegetação apresentar maiores quedas médias de poro-pressões de água $(22 \mathrm{kPa})$ no período de estiagem analisado do que a porção com revestimento superficial em argamassa $(7 \mathrm{kPa})$ em ambos os tipos de solo, ou seja, uma diferença de $15 \mathrm{kPa}$ nas quedas das duas porções do talude, conforme apresentado na Tabela 5.3. 
Tabela 5.3: Redução de poro-pressão de água durante estiagem entre os dias $10 \mathrm{e}$ 26 de junho

\begin{tabular}{|c|c|c|c|c|}
\hline \multirow{2}{*}{ Linha } & $\begin{array}{c}\text { Profundidade }(\mathrm{m}) \\
\text { Tipo de Solo }\end{array}$ & \multicolumn{3}{|c|}{ Período de Estiagem } \\
\cline { 3 - 5 } & Vegetação & Argamassa & Veg - Arg \\
\hline 1 & 0,5 argila & -59 & -2 & -57 \\
1 & 1,5 argila & -5 & -3 & -2 \\
3 & 3,0 argila & -18 & -18 & 0 \\
\hline 5 & 0,5 silte & -12 & +3 & -15 \\
4 & 1,5 silte & -19 & -11 & -8 \\
4 & 3,0 silte & -16 & -11 & -5 \\
\hline- & Média das reduções & -22 & -7 & -15 \\
\hline
\end{tabular}

\section{Comparação entre tipos de solo}

Analisando-se as poro-pressões de água no início (10/06) e ao final do período de estiagem (26/07), em ambos os tipos de solo e revestimentos, verifica-se que há uma tendência do silte apresentar menores poro-pressões de água do que a argila revestida, conforme pode ser visto na Tabela 5.4.

Tabela 5.4: Poro-pressão de água no início e ao final da estiagem, em $\mathrm{kPa}$

\begin{tabular}{|c|c|c|c|c|c|}
\hline \multirow{2}{*}{ Linha } & Profund $(\mathrm{m})$ & \multicolumn{2}{|c|}{ Vegetação } & \multicolumn{2}{c|}{ Argamassa } \\
\cline { 3 - 6 } & Tipo de Solo & $10 / 06$ & $26 / 07$ & $10 / 06$ & $26 / 07$ \\
\hline 1 & 0,5 argila & -4 & -63 & -5 & -6 \\
1 & 1,5 argila & -1 & -6 & -1 & -5 \\
3 & 3,0 argila & -22 & -40 & -14 & -32 \\
\hline- & Valores médios & -9 & -36 & -7 & -14 \\
\hline 5 & 0,5 silte & -19 & -32 & -17 & -14 \\
4 & 1,5 silte & -22 & -41 & -24 & -35 \\
4 & 3,0 silte & -18 & -34 & -23 & -34 \\
\hline- & Valores médios & -19 & -35 & -21 & -28 \\
\hline
\end{tabular}


Por exemplo, em 10/06 a argila revestida com vegetação apresentava poro-pressão média, nas três profundidades monitoradas de $-9 \mathrm{kPa}$ e o silte $-19 \mathrm{kPa}$. A argila revestida com argamassa apresentava poro-pressão média em 10/01 de -7 kPa e o silte -21 kPa; e em 26/07 a argila apresentava -14 kPa e o silte -28 kPa. Exceção a essa tendência são os resultados obtidos para a porção com vegetação no final do período de estiagem, 26/07, que conforme visto anteriormente sofreu influência de gradientes de potencial hidráulico gerados pelas raízes da vegetação, principalmente na profundidade de $0,5 \mathrm{~m}$.

Será analisado a seguir porque o silte apresenta menores poro-pressões de água do que a argila. As variáveis que regem o fluxo de água no solo são permeabilidade e potencial hidráulico. O coeficiente de permeabilidade médio a $45^{\circ}$ saturada do silte, que é a direção preferencial do fluxo $\left(5 \times 10^{-4} \mathrm{~cm} / \mathrm{s}\right)$ durante o período analisado acima, é maior que o coeficiente de permeabilidade médio a $45^{\circ}$ da argila $\left(1 \times 10^{-6}\right.$ $\mathrm{cm} / \mathrm{s}$ ) no período analisado.

Os coeficientes de permeabilidade acima foram obtidos a partir do levantamento dos coeficientes de permeabilidades no início e no final do período de estiagem analisado para as respectivas poro-pressões de água indicadas na Tabela 5.4. Os resultados desse levantamento são apresentadas na Tabela 5.5, e foram determinados a partir da Figura 4.59: função condutividade hidráulica do aterro argiloso e do solo residual siltoso, na direção $45^{\circ} \mathrm{com}$ a horizontal, para o silte e para a argila.

Os resultados indicaram que a permeabilidade da argila manteve-se igual à sua permeabilidade saturada e a do silte caiu significativamente, durante o período analisado. Isto ocorreu, porque a argila tem elevado valor de entrada de ar e, portanto sua permeabilidade somente se reduz a partir de cerca de $150 \mathrm{kPa}$, sendo assim esse solo manteve-se saturado durante o período, e sua permeabilidade não se reduziu. De outro lado, o silte apresentou redução de permeabilidade durante o período devido à redução de poro-pressão de água. 
Tabela 5.5: Coeficientes de permeabilidade no início e ao final da estiagem, em cm/s

\begin{tabular}{|l|l|l|l|l|l|}
\hline Linha & Profund (m) & \multicolumn{2}{|c|}{ Vegetação } & \multicolumn{2}{c|}{ Argamassa } \\
\cline { 3 - 6 } & Tipo de Solo & $10 / 06$ & $26 / 07$ & $10 / 06$ & $26 / 07$ \\
\hline 1 & 0,5 argila & $1 \times 10^{-6}$ & $1 \times 10^{-6}$ & $1 \times 10^{-6}$ & $1 \times 10^{-6}$ \\
1 & 1,5 argila & $1 \times 10^{-6}$ & $1 \times 10^{-6}$ & $1 \times 10^{-6}$ & $1 \times 10^{-6}$ \\
3 & 3,0 argila & $1 \times 10^{-6}$ & $1 \times 10^{-6}$ & $1 \times 10^{-6}$ & $1 \times 10^{-6}$ \\
\hline- & Valores médios & \multicolumn{5}{|c|}{$1 \times 10^{-6}$} \\
\hline 5 & 0,5 silte & $1 \times 10^{-4}$ & $1 \times 10^{-4}$ & $2 \times 10^{-4}$ & $2 \times 10^{-4}$ \\
4 & 1,5 silte & $1 \times 10^{-4}$ & $5 \times 10^{-5}$ & $1 \times 10^{-4}$ & $7 \times 10^{-5}$ \\
4 & 3,0 silte & $2 \times 10^{-4}$ & $7 \times 10^{-5}$ & $1 \times 10^{-4}$ & $7 \times 10^{-5}$ \\
\hline- & Valores médios & \multicolumn{5}{|c|}{$5 \times 10^{-4}$} \\
\hline
\end{tabular}

O potencial hidráulico médio na argila no período analisado foi 1,8 . Sendo 1,0 a parcela devido ao potencial gravitacional e 0,8 a parcela devido ao potencial de pressão: $18 \mathrm{kPa} /\left(10 \mathrm{kN} / \mathrm{m}^{3} \times 2,5 \mathrm{~m}\right)$, onde $18 \mathrm{kPa}$ é a diferença média entre as poro-pressões a $0,5 \mathrm{~m}$ de profundidade e $3,0 \mathrm{~m}$ de profundidade, durante o período analisado, e 2,5 m é a distância entre os dois pontos analisados. Seguindo o mesmo raciocínio, o silte apresentou potencial hidráulico médio igual a 1,2, sendo 1,0 devido ao potencial gravitacional e 0,2 devido ao potencial de pressão: $5 \mathrm{kPa} /\left(10 \mathrm{kN} / \mathrm{m}^{3} \mathrm{x}\right.$ $2,5 \mathrm{~m})$.

Analisando-se as duas variáveis que interferem no fluxo não saturado nos solos: permeabilidade significativamente maior do silte do que da argila e potencial hidráulico 50 \% maior na argila, é esperado maior fluxo de água em direção ao lençol freático no silte do que na argila e, portanto, maiores variações de poropressão de água no silte do que na argila. 


\subsubsection{Período chuvoso}

Os perfis de poro-pressões de água apresentados abaixo indicam o avanço de frente de umedecimento no período entre 18 e 25 de janeiro. Período chuvoso do ano em que houve aumento do volume de chuvas, com as seguintes intensidades diárias: $6 \mathrm{~mm}$ em 16/01, $1 \mathrm{~mm}$ em 17/01, 2 mm em 18/01, 3 mm em 19/01, 14 mm em 20/01 e $21 \mathrm{~mm}$ em 21/01, totalizando $47 \mathrm{~mm}$ de precipitação, ou 7,8 $\mathrm{mm}$ por dia, conforme pode ser visto nas Figuras 5.25, 5.26, 5.27 e 5.28.

Para a elaboração dos perfis foram utilizadas as leituras na Linha 1 com profundidades de $0,5 \mathrm{~m}$ e $1,5 \mathrm{~m}$, onde há argila areno-siltosa; e na Linha $5 \mathrm{com}$ profundidades de $0,5 \mathrm{~m} \mathrm{e} 1,5 \mathrm{~m}$, onde há silte areno-argiloso.

\section{Comparação entre revestimentos}

Nas Figuras 5.25 e 5.26 são apresentados os perfis de poro-pressão de água nas porções do talude revestidas em vegetação e argamassa, respectivamente, ambas em solo argiloso. Observa-se que a $0,5 \mathrm{~m}$ de profundidade as poro-pressões de água elevaram-se pouco menos na porção com vegetação $(7 \mathrm{kPa})$ do que na porção com revestimento em argamassa (10 kPa). Ao contrário, a 1,5 m de profundidade as elevações de poro-pressão cresceram pouco menos na porção com revestimento em argamassa ( $3 \mathrm{kPa})$ do que na porção vegetada ( $6 \mathrm{Kpa})$.

Destaca-se na Figura 5.25 os valores positivos de poro-pressão de água na crista do talude em 22 de janeiro. Provavelmente o perfil de poro-pressão de água próximo do perfil da linha hidrostática se deve ao fluxo constante de água para essa região do talude. Esse fluxo pode ter sido causado por abastecimento constante de água empoçada nas áreas adjacentes, e também pela permeabilidade horizontal da argila ser significativamente maior que a vertical, mantendo a região com elevadas poropressões de água. 


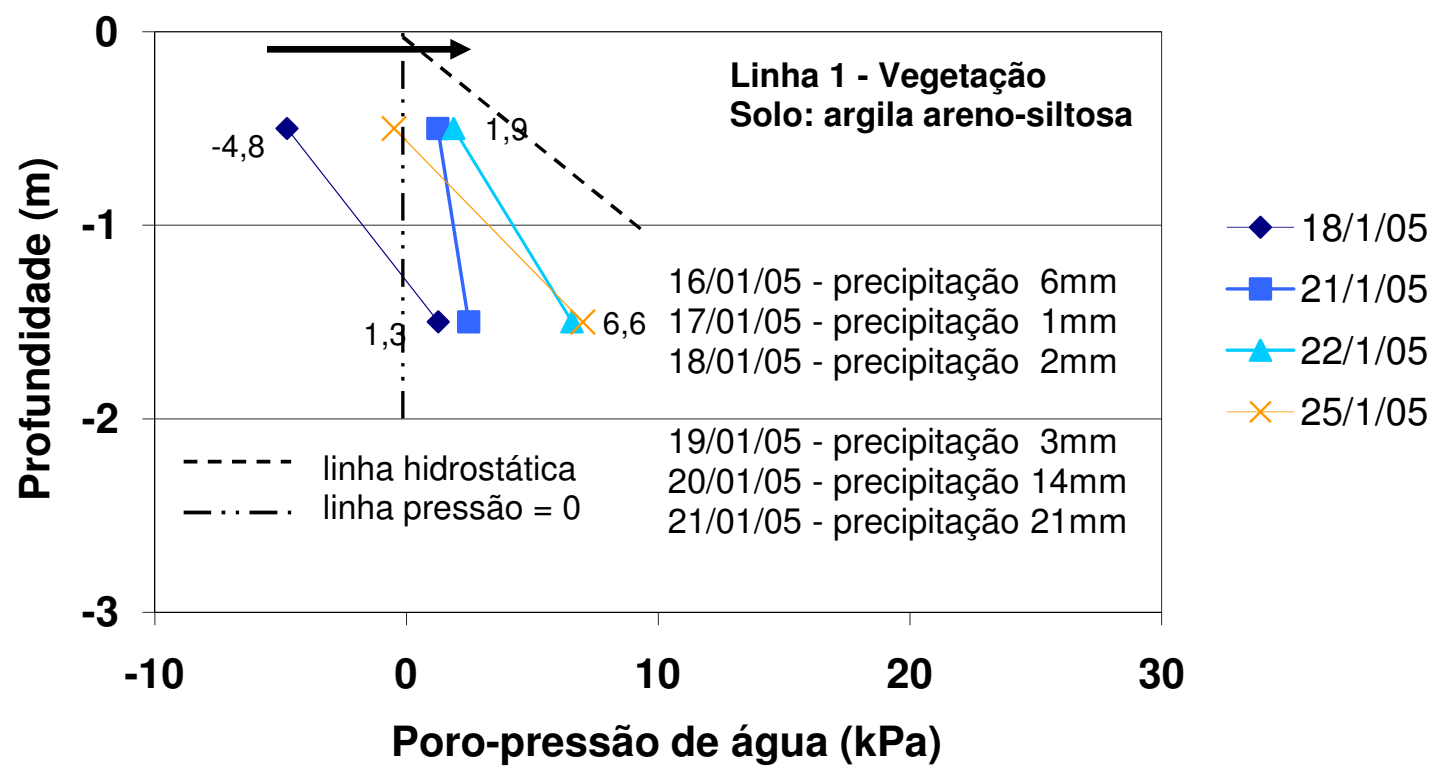

Figura 5.25: Perfis de poro-pressão de água durante período chuvoso de 18 a 25 de janeiro, em área com solo argiloso e revestimento superficial em vegetação

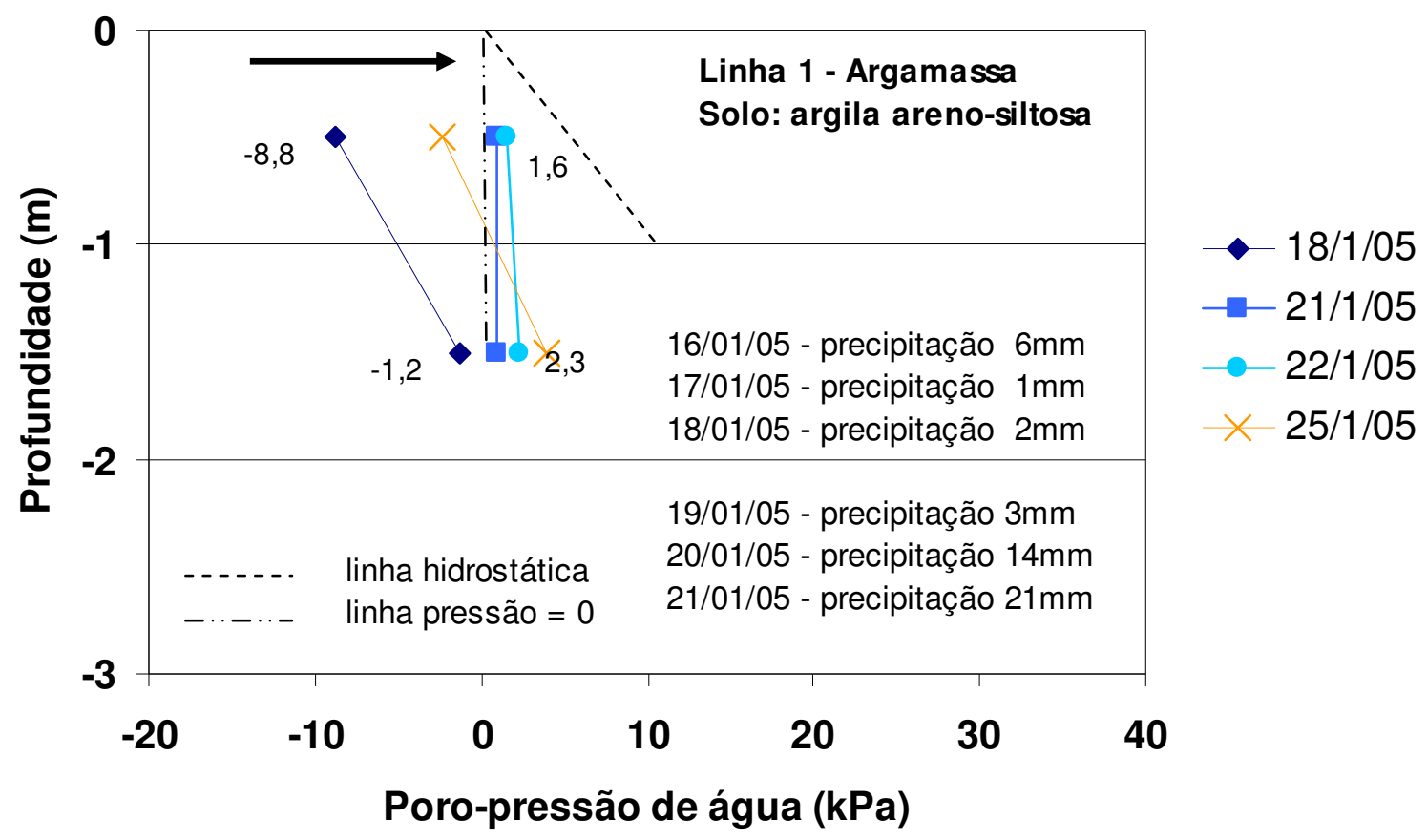

Figura 5.26: Perfis de poro-pressão de água durante período chuvoso de 18 a 25 de janeiro, em área com solo argiloso e revestimento superficial em argamassa

Nas Figuras 5.27 e 5.28 são apresentados os avanços das frentes de umedecimento nas porções do talude revestidas em argamassa e vegetação, respectivamente, 
ambas em solo siltoso. Observa-se que a 0,5 m de profundidade as poro-pressões de água reduziram-se igualmente nas porções com revestimento em argamassa e vegetação $(4 \mathrm{kPa})$.

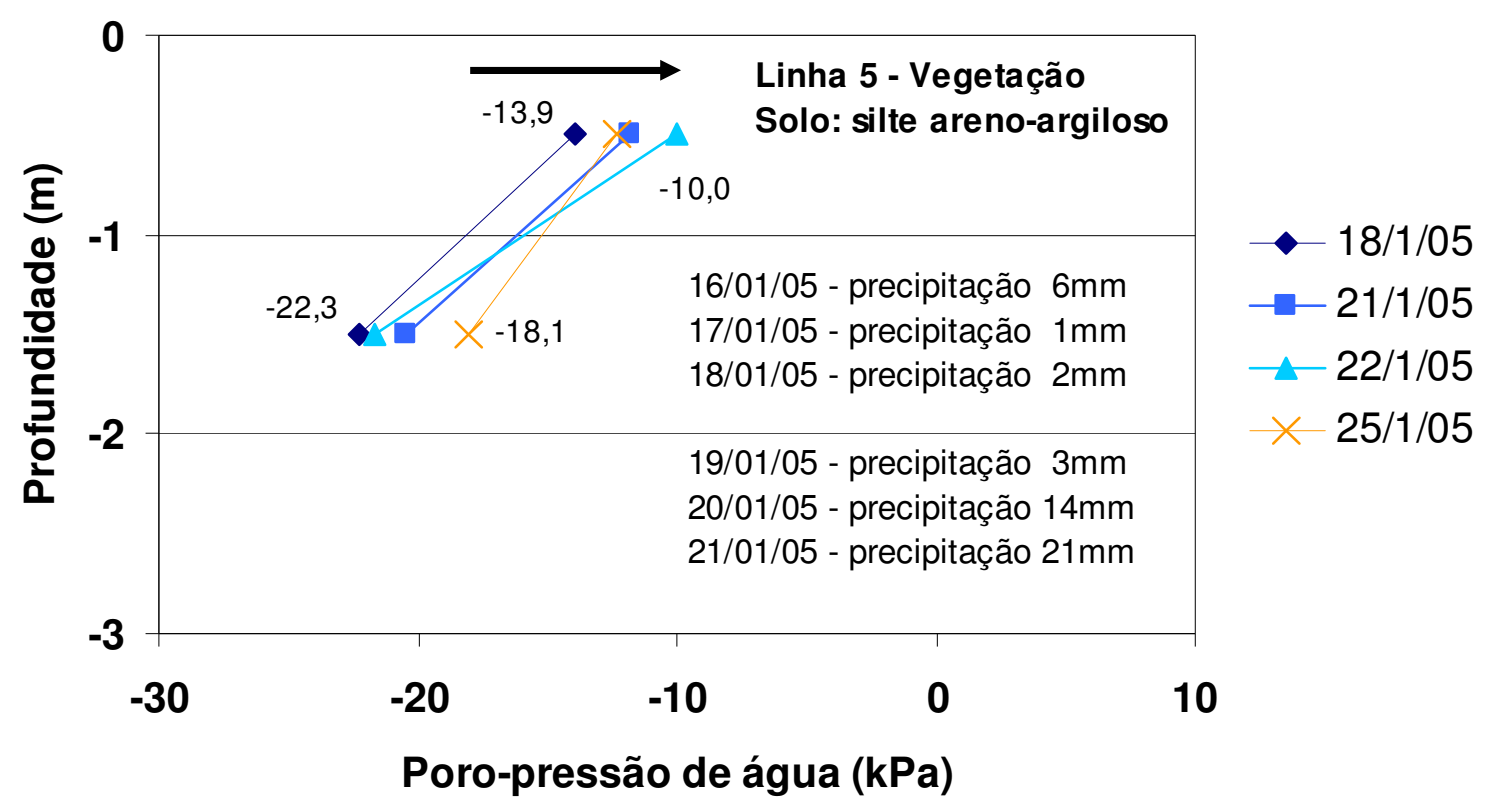

Figura 5.27: Perfis de poro-pressão de água durante período chuvoso de 18 a 25 de janeiro, em área com solo siltoso e revestimento superficial em vegetação

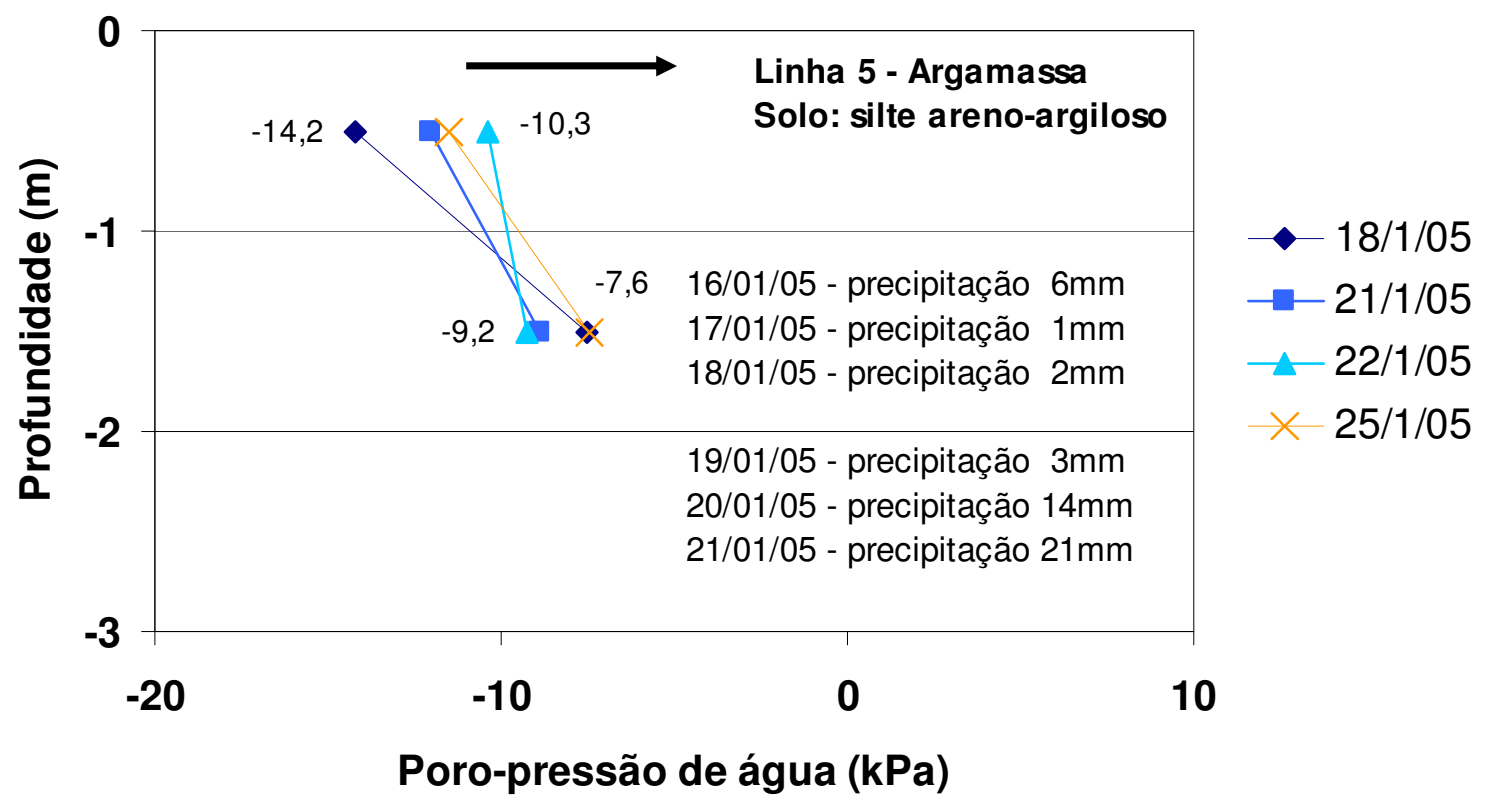

Figura 5.28: Perfis de poro-pressão de água durante período chuvoso de 18 a 25 de janeiro, em área com solo siltoso e revestimento superficial em argamassa 
A 1,5 m de profundidade as elevações de poro-pressão foram pouco menores na porção argamassada (1 Kpa) do que na porção com vegetação $(4 \mathrm{kPa})$.

De uma maneira geral as variações de poro-pressão de água no período chuvoso de uma semana iniciado em 18 de janeiro de 2005 foram pequenas, entre 1 e $10 \mathrm{kPa}$, conforme pode ser visto na Tabela 5.6. Comparando-se o comportamento da porção argamassada com a da revestida com vegetação verifica-se que as elevações de poro-pressão de água foram semelhantes.

Tabela 5.6: Elevação de poro-pressão de água durante período chuvoso, em kPa

\begin{tabular}{|c|c|c|c|c|}
\hline \multirow{2}{*}{ Linha } & Profundidade $(\mathrm{m})$ & \multicolumn{3}{|c|}{ Período Chuvoso } \\
\cline { 3 - 5 } & Tipo de Solo & Vegetação & Argamassa & Veg - Arg \\
\hline 1 & 0,5 argila & +7 & +10 & -4 \\
1 & 1,5 argila & +6 & +3 & +3 \\
\hline 5 & 0,5 silte & +4 & +4 & 0 \\
5 & 1,5 silte & +4 & +1 & +3 \\
\hline
\end{tabular}

\section{Comparação entre tipos de solo}

Analisando-se as poro-pressões de água em 18/01 e 22 a 25/01, início e final do período chuvoso analisado, em ambos os tipos de solo e revestimentos, verifica-se que há uma tendência do silte areno-argiloso apresentar menores leituras em ambos os revestimentos e datas analisadas, conforme pode ser observado na Tabela 5.7.

Tabela 5.7: Poro-pressões de água durante período chuvoso, em $\mathrm{kPa}$

\begin{tabular}{|l|l|l|l|l|l|}
\hline Linha & Prof. $(\mathrm{m})$ & Veget & Argam & Veget & Argam \\
\cline { 3 - 6 } & Tipo Solo & $18 / 01$ & $18 / 01$ & $22-25 / 01$ & $22-25 / 01$ \\
\hline 1 & 0,5 argila & -5 & -9 & +2 & +2 \\
\cline { 3 - 6 } 1 & 1,5 argila & +1 & -1 & +7 & +4 \\
\hline 5 & 0,5 silte & -14 & -14 & -10 & -10 \\
\cline { 3 - 6 } 5 & 1,5 silte & -22 & -8 & -18 & -7 \\
\hline
\end{tabular}


Esse resultado é compatível com as características de permeabilidade dos solos e com os gradientes de pressão hidráulica atuantes no período chuvoso analisado.

\subsubsection{Distribuição de poro-pressão d'água no talude}

Leituras dos 25 tensiômetros instalados em todas as linhas e profundidades, e ambos os revestimentos superficiais do talude experimental foram usadas para produzir o contorno de iso-valores de poro-pressões de água no talude em seis datas escolhidas: $1^{\circ}$ de Fevereiro, 12 de Abril, 20 de Maio, 25 de Maio, 22 de Julho e 31 de Agosto. As figuras a serem apresentadas ilustram a magnitude e a distribuição de poro-pressão de água nas porções do talude revestidas com argamassa e com vegetação e identificam o regime de movimentação de água na sub-superfície do terreno.

Os seis eventos específicos escolhidos, indicados acima, foram selecionados por apresentar as três maiores e três menores poro-pressões de água médias do talude, considerando todos os tensiômetros instalados, após períodos de chuvas intensas e períodos de estiagem, respectivamente. As datas selecionadas são apresentados na Tabela 5.8 associadas às respectivas poro-pressões de água médias no talude, e às precipitações prévias acumuladas até o dia anterior da data do evento.

Tabela 5.8: Três datas com maiores e menores poro-pressões de água médias

\begin{tabular}{|c|c|c|c|c|c|}
\hline \multirow{2}{*}{$\begin{array}{c}\text { Data do } \\
\text { Evento }\end{array}$} & $\begin{array}{c}\text { Poro-Pressões } \\
\text { de Água } \\
\text { Médias }(\mathrm{kPa})\end{array}$ & \multicolumn{4}{|c|}{$\begin{array}{c}\text { Precipitação Acumulada antes } \\
\text { do Evento }(\mathrm{mm})\end{array}$} \\
\cline { 3 - 6 } & 3 dias & 7 dias & 14 dias & 28 dias \\
\hline 1 o de Fever & -5 & 3 & 38 & 99 & 199 \\
\hline 12 de Abril & -7 & 0 & 0 & 48 & 169 \\
\hline 25 de Maio & -9 & 127 & 142 & 142 & 161 \\
\hline 20 de Maio & -17 & 0 & 0 & 0 & 28 \\
\hline 22 de Julho & -22 & 0 & 0 & 0 & 13 \\
\hline 31 de Agosto & -26 & 0 & 0 & 0 & 9 \\
\hline
\end{tabular}




\subsubsection{Períodos de Estiagem}

\section{Distribuição de poro-pressão de água no talude em 20 de maio}

Na Figura 5.29 é apresentada a distribuição de poro-pressão de água no talude, em 20 de maio. Os contornos de poro-pressão de água foram traçados pela interpolação dos dados de medição nos tensiômetros instalados em campo, cujos valores são apresentados na tabela localizada do lado esquerdo da figura, juntamente com o potencial total do ponto onde está localizado o tensímetro. As interpolações foram feitas descartando-se dados incoerentes com a forma esperada do avanço de secagem do solo.

\begin{tabular}{|c|c|c|}
\hline Tens. & $\mathbf{u}(\mathbf{k P a})$ & $\mathbf{h}_{\mathbf{T}}(\mathbf{m})$ \\
\hline $\mathrm{A}$ & -31 & $-2,2$ \\
\hline $\mathrm{B}$ & -24 & $-2,4$ \\
\hline $\mathrm{C}$ & -24 & 2,7 \\
\hline $\mathrm{D}$ & -28 & $\mathbf{0 , 8}$ \\
\hline $\mathrm{E}$ & -49 & 4,0 \\
\hline $\mathrm{F}$ & -22 & $\mathbf{5 , 8}$ \\
\hline $\mathrm{G}$ & -26 & $\mathbf{3 , 8}$ \\
\hline $\mathrm{H}$ & -5 & 10,4 \\
\hline $\mathrm{I}$ & -4 & 9,0 \\
\hline $\mathrm{J}$ & -16 & 13,6 \\
\hline $\mathrm{L}$ & -3 & 13,9 \\
\hline $\mathrm{M}$ & -7 & 11,3 \\
\hline
\end{tabular}

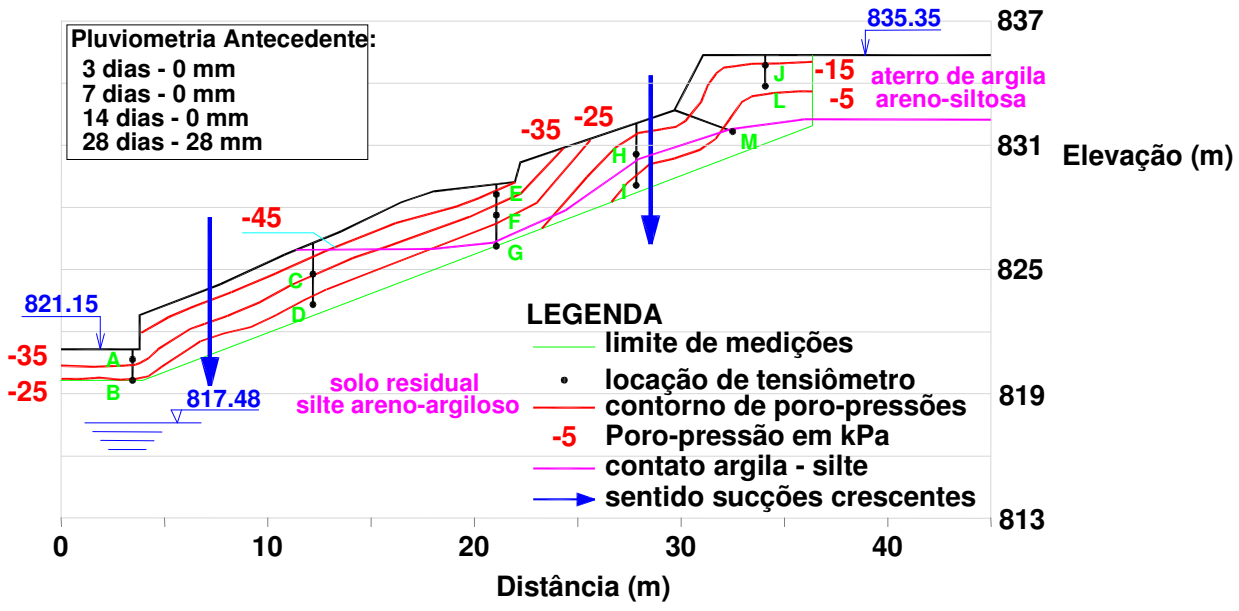

(a) Porção do talude com revestimento em vegetação, em 20/05/05

\begin{tabular}{|c|c|c|}
\hline Tens. & $\mathbf{u}(\mathbf{k P a})$ & $\mathbf{h}_{\mathbf{T}} \mathbf{( m )}$ \\
\hline 1 & $\mathbf{- 1 8}$ & $\mathbf{- 0 , 8}$ \\
\hline 2 & -10 & $\mathbf{- 1 , 0}$ \\
\hline 3 & $\mathbf{- 3 1}$ & $\mathbf{2 , 7}$ \\
\hline 4 & $\mathbf{- 2 6}$ & $\mathbf{1 , 7}$ \\
\hline 5 & $\mathbf{- 2 5}$ & $\mathbf{6 , 8}$ \\
\hline 6 & $\mathbf{- 2 5}$ & $\mathbf{5 , 8}$ \\
\hline 7 & $\mathbf{- 2 3}$ & $\mathbf{4 , 6}$ \\
\hline 8 & $\mathbf{- 4}$ & $\mathbf{1 2 , 5}$ \\
\hline 9 & $\mathbf{- 6}$ & $\mathbf{1 0 , 8}$ \\
\hline 10 & $\mathbf{- 1}$ & $\mathbf{1 4 , 9}$ \\
\hline 11 & $-\mathbf{4}$ & $\mathbf{1 5 , 6}$ \\
\hline 12 & $-\mathbf{2}$ & $\mathbf{1 4 , 8}$ \\
\hline 13 & $\mathbf{2}$ & $\mathbf{1 4 , 2}$ \\
\hline
\end{tabular}

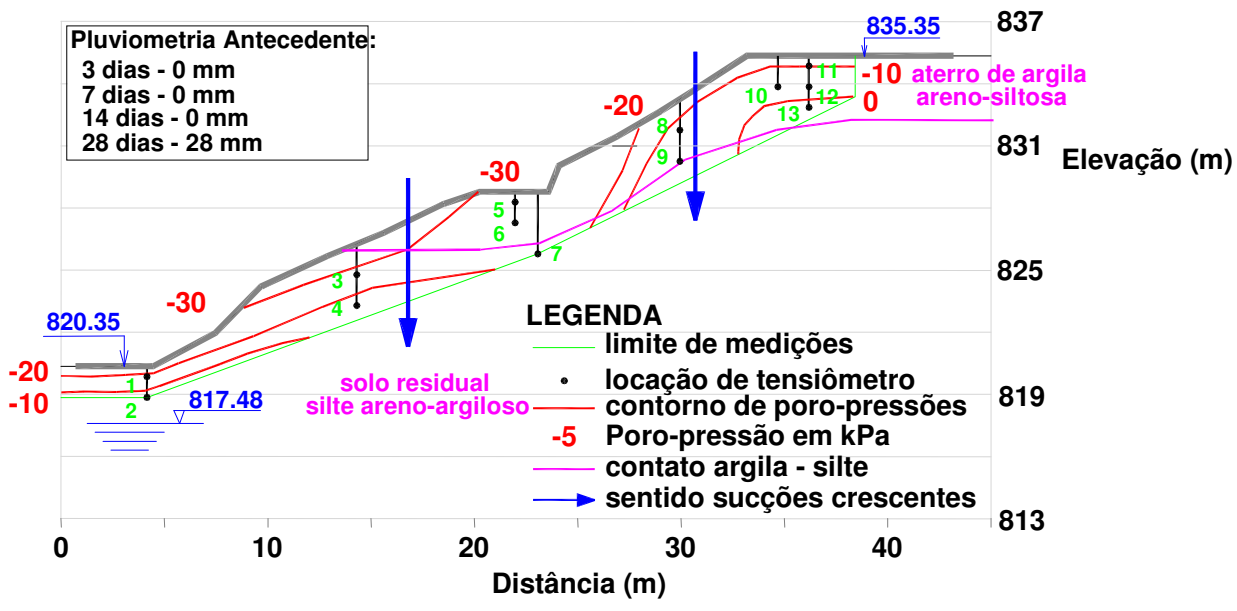

(b) Porção do talude com revestimento em argamassa, em 20/05/05

Figura 5.29: Distribuição de poro-pressões no talude em 20 de Maio 
Os registros no solo argiloso (Linhas 1 a 3 ) indicaram valores menores de poropressão de água, entre $-5 \mathrm{kPa}$ e $-45 \mathrm{kPa}$, na porção com vegetação (Fig. 5.29-a), do que na porção revestida com argamassa, entre $0 \mathrm{kPa}$ e $-30 \mathrm{kPa}$.

No solo siltoso (Linhas 4 e 5) os registros indicaram também valores menores de poro-pressão de água, entre -25 kPa e -45 kPa, na porção com vegetação, do que na porção revestida com argamassa (Fig. 5.29-b), entre -10 kPa e -30 kPa.

Isso indica que a porção do talude com revestimento em argamassa apresentou menor transferência de umidade do solo para o meio externo, no período de estiagem analisado e na profundidade instrumentada, em relação à porção com vegetação tipo capim alto.

A argila permaneceu saturada durante todo o período de monitoramento, pois seu ponto de entrada de ar é -150 kPa, poro-pressão que não atingida nesse período. Portanto não foi possível haver fluxo de ar/vapor d'água durante o período de monitoramento. E, portanto a causa da redução das poro-pressões de água, na porção vegetada nesse solo, foi o gradiente de potencial hidráulico gerado pelas raízes da vegetação.

As flechas indicadas na Figura 5.29 representam o sentido em que o potencial hidráulico total (potencial devido à poro-pressão de água somado ao potencial devido à altura em relação à cota onde está instalado tensiômetro $\mathrm{B}$ ou 2 , conforme a seção analisada) diminui, até a profundidade instrumentada, na data indicada na figura. Considerando que o fluxo de água ocorre dos maiores potenciais para os menores, pode-se inferir do resultado obtido, que há um fluxo de água de cima para baixo.

\section{Distribuição de poro-pressão de água no talude em 22 de julho}

A distribuição de poro-pressão de água em 22 de Julho é apresentada na Figura 5.30. Os registros no solo argiloso (Linhas 1 a 3 ) indicaram valores menores de poro-pressão de água, entre $-5 \mathrm{kPa}$ e $-65 \mathrm{kPa}$, na porção com vegetação, do que na 
porção com argamassa, entre $-10 \mathrm{kPa}$ e $-25 \mathrm{kPa}$. No solo siltoso (Linhas 4 e 5) os registros indicaram também valores menores de poro-pressão de água, entre -25 $\mathrm{kPa}$ e $-45 \mathrm{kPa}$, na porção com vegetação, do que na porção com argamassa, entre $10 \mathrm{kPa}$ e $-30 \mathrm{kPa}$. Esse período apresentou poro-pressões de água menores que as de 20 de maio. As precipitações acumuladas de 28 dias, em 22 de julho, somam 13 $\mathrm{mm}$, e as de 20 de maio, $28 \mathrm{~mm}$. Conforme esperado, menores precipitações acumuladas levam a menores poro-pressões de água no talude.

\begin{tabular}{|c|c|c|}
\hline Tens. & $\mathbf{u}(\mathbf{k P a})$ & $\mathbf{h}_{\mathbf{T}} \mathbf{( m )}$ \\
\hline $\mathrm{A}$ & -32 & $-2,3$ \\
\hline $\mathrm{B}$ & -26 & $-2,7$ \\
\hline $\mathrm{C}$ & -36 & $\mathbf{1 , 4}$ \\
\hline $\mathrm{D}$ & -32 & $\mathbf{0 , 4}$ \\
\hline $\mathrm{E}$ & -29 & $\mathbf{6 , 0}$ \\
\hline $\mathrm{F}$ & -17 & $\mathbf{6 , 3}$ \\
\hline $\mathrm{G}$ & -40 & 2,4 \\
\hline $\mathrm{H}$ & -28 & $\mathbf{8 , 0}$ \\
\hline $\mathrm{I}$ & - & - \\
\hline $\mathrm{J}$ & -50 & 10,1 \\
\hline $\mathrm{L}$ & -6 & $\mathbf{1 3 , 6}$ \\
\hline $\mathrm{M}$ & -8 & $\mathbf{1 1 , 2}$ \\
\hline
\end{tabular}

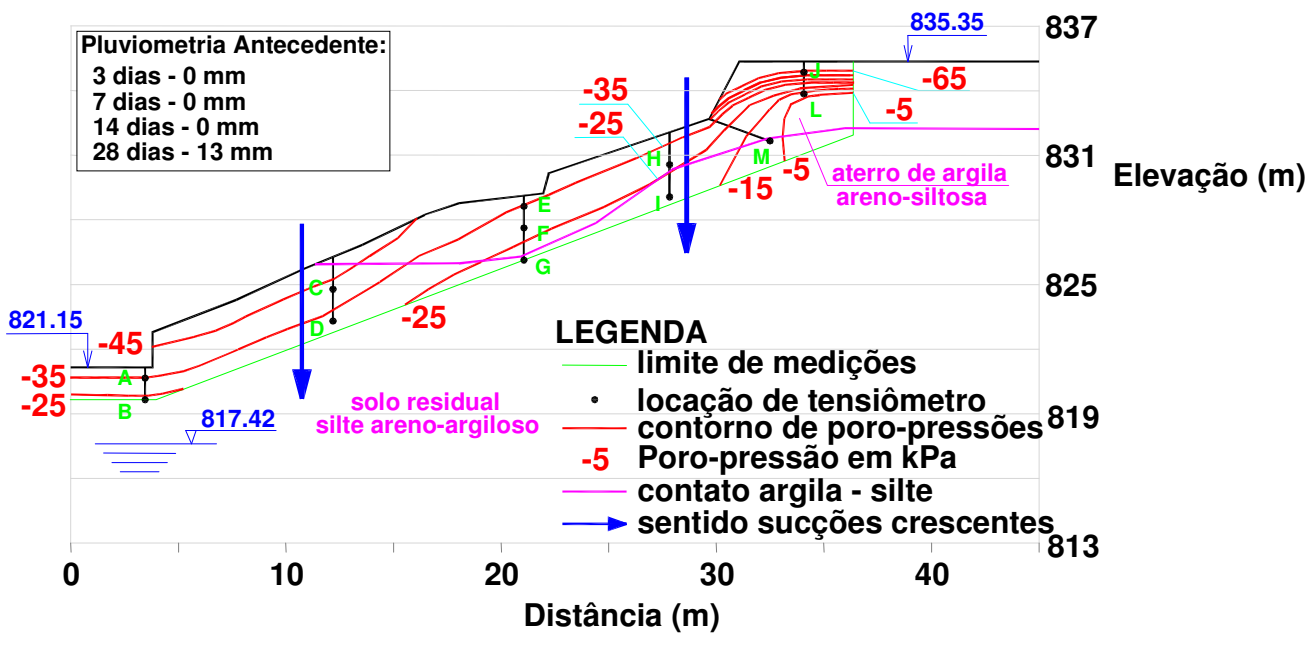

(a) Porção do talude com revestimento em vegetação, em 22/07/05

\begin{tabular}{|c|c|c|}
\hline Tens. & $\mathbf{u}(\mathbf{k P a})$ & $\mathbf{h}_{\mathbf{T}}(\mathbf{m})$ \\
\hline 1 & $-\mathbf{- 1 6}$ & $\mathbf{- 0 , 6}$ \\
\hline 2 & $\mathbf{- 1 1}$ & $\mathbf{- 1 , 1}$ \\
\hline 3 & $\mathbf{- 3 3}$ & $\mathbf{2 , 5}$ \\
\hline 4 & $\mathbf{- 3 3}$ & $\mathbf{1 , 0}$ \\
\hline 5 & $\mathbf{- 2 7}$ & $\mathbf{6 , 6}$ \\
\hline 6 & $\mathbf{- 2 3}$ & $\mathbf{6 , 1}$ \\
\hline 7 & $\mathbf{- 2 3}$ & $\mathbf{4 , 6}$ \\
\hline 8 & $-\mathbf{8}$ & $\mathbf{1 2 , 1}$ \\
\hline 9 & $\mathbf{- 1 4}$ & $\mathbf{1 0 , 0}$ \\
\hline 10 & -4 & $\mathbf{1 4 , 6}$ \\
\hline 11 & $-\mathbf{1 0}$ & $\mathbf{1 5 , 0}$ \\
\hline 12 & - & - \\
\hline 13 & -2 & $\mathbf{1 3 , 8}$ \\
\hline
\end{tabular}

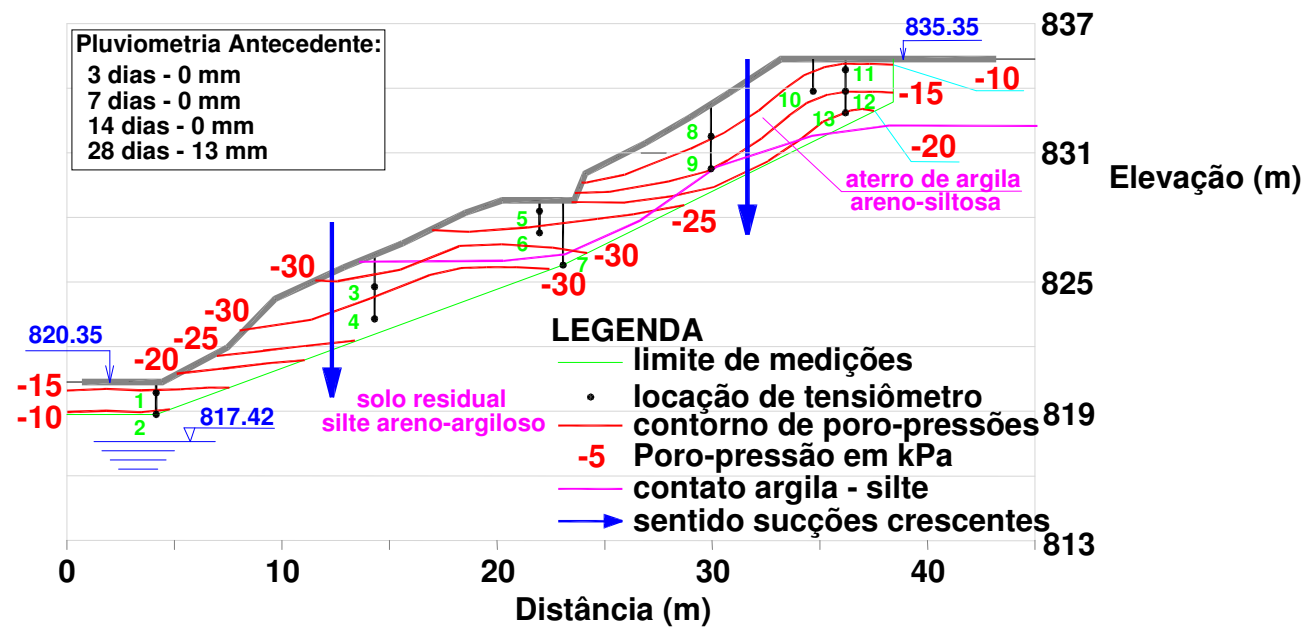

(b) Porção do talude com revestimento em argamassa, em 22/07/05

Figura 5.30: Distribuição de poro-pressões no talude em 22 de Julho 
Observa-se na linha 5, localizada no pé do talude em solo siltoso, a 1,5 m de profundidade, com ambos os tipos de revestimento, apresentou maiores poropressões de água do que a linha 4 , entre o meio e o pé do talude, na mesma profundidade. Provavelmente, isso ocorreu por efeito da proximidade com o nível d'água do terreno, que por equilíbrio estático mantém poro-pressões de água maiores mesmo sob o efeito dos gradientes de potencial hidráulico provocados pelas raízes da vegetação.

Nessa data analisada (22 de julho) as porções do talude revestidas com argamassa e vegetação apresentaram potenciais totais decrescentes de cima para baixo indicando fluxo de água no mesmo sentido. Essa constatação indica que na porção do talude revestida com vegetação os gradientes de potencial gravitacional foram mais intensos que os gradientes de potencial hidráulico aplicados pelas raízes da vegetação.

\section{Distribuição de poro-pressão de água no talude em 31 de agosto}

Em 31 de Agosto os registros no solo argiloso (Linhas 1 a 3 ) indicaram valores menores de poro-pressão de água, entre $-10 \mathrm{kPa}$ e $-60 \mathrm{kPa}$, na porção com vegetação, do que na porção com argamassa, entre $-5 \mathrm{kPa}$ e $-40 \mathrm{kPa}$, conforme pode ser visto na Figura 5.31. No solo siltoso (Linhas 4 e 5 ) os registros indicaram também valores menores de poro-pressão de água, entre -20 kPa e -60 kPa, na porção com vegetação, do que na porção com argamassa, entre $-10 \mathrm{kPa}$ e $-40 \mathrm{kPa}$.

As flechas voltadas para baixo indicam, assim como nas duas datas de estiagem analisadas anteriormente, que um fluxo de água na direção do interior do maciço. 

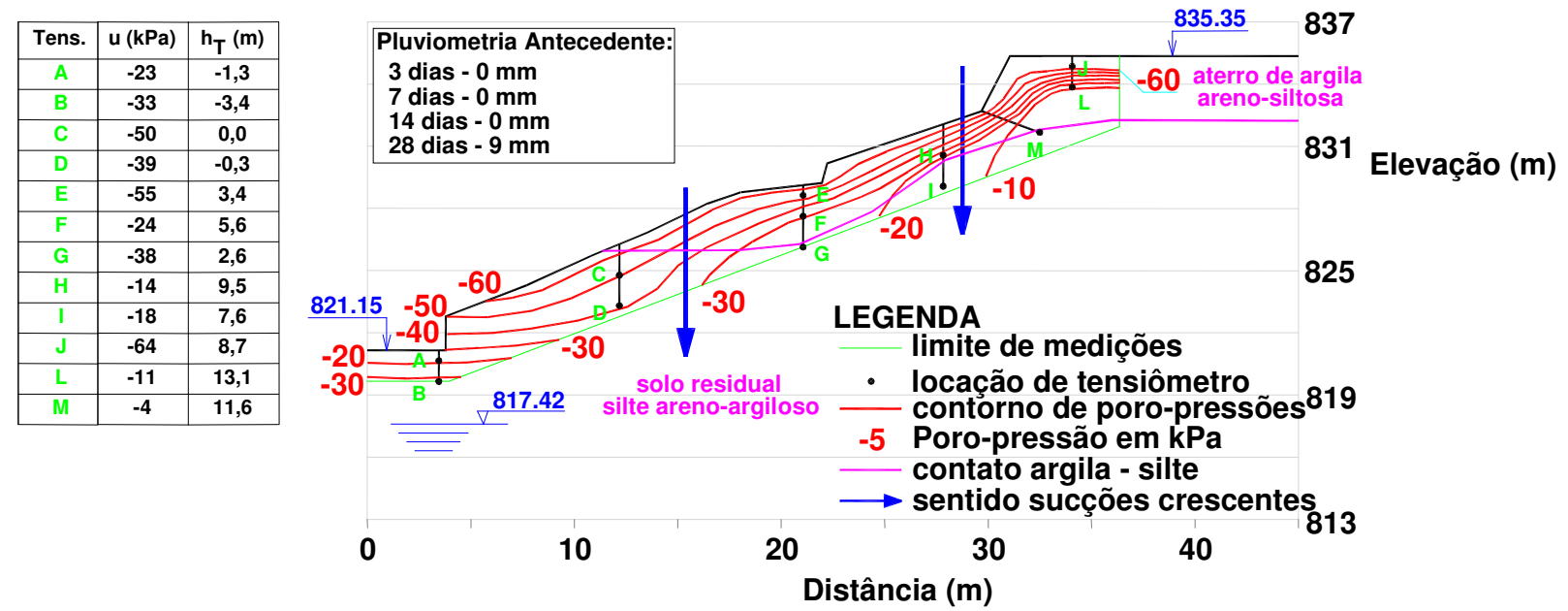

(a) Porção do talude com revestimento em vegetação, em 31/08/05

\begin{tabular}{|c|c|c|}
\hline Tens. & $\mathbf{u} \mathbf{~ ( k P a )}$ & $\mathbf{h}_{\mathbf{T}} \mathbf{( m )}$ \\
\hline 1 & $-\mathbf{1 6}$ & $\mathbf{- 0 , 6}$ \\
\hline 2 & $\mathbf{- 8}$ & $\mathbf{- 0 , 8}$ \\
\hline 3 & $\mathbf{- 3 9}$ & $\mathbf{1 , 9}$ \\
\hline 4 & $\mathbf{- 3 3}$ & $\mathbf{1 , 0}$ \\
\hline 5 & $\mathbf{- 3 2}$ & $\mathbf{6 , 1}$ \\
\hline 6 & $\mathbf{- 3 6}$ & $\mathbf{4 , 7}$ \\
\hline 7 & $\mathbf{- 3 4}$ & $\mathbf{3 , 4}$ \\
\hline 8 & $\mathbf{- 5}$ & $\mathbf{1 2 , 4}$ \\
\hline 9 & $\mathbf{- 1 8}$ & $\mathbf{9 , 6}$ \\
\hline 10 & $\mathbf{- 1}$ & $\mathbf{1 4 , 9}$ \\
\hline 11 & $-\mathbf{6}$ & $\mathbf{1 5 , 4}$ \\
\hline 12 & $\mathbf{- 1 2}$ & $\mathbf{1 3 , 8}$ \\
\hline 13 & $\mathbf{- 2 7}$ & $\mathbf{1 1 , 2}$ \\
\hline
\end{tabular}

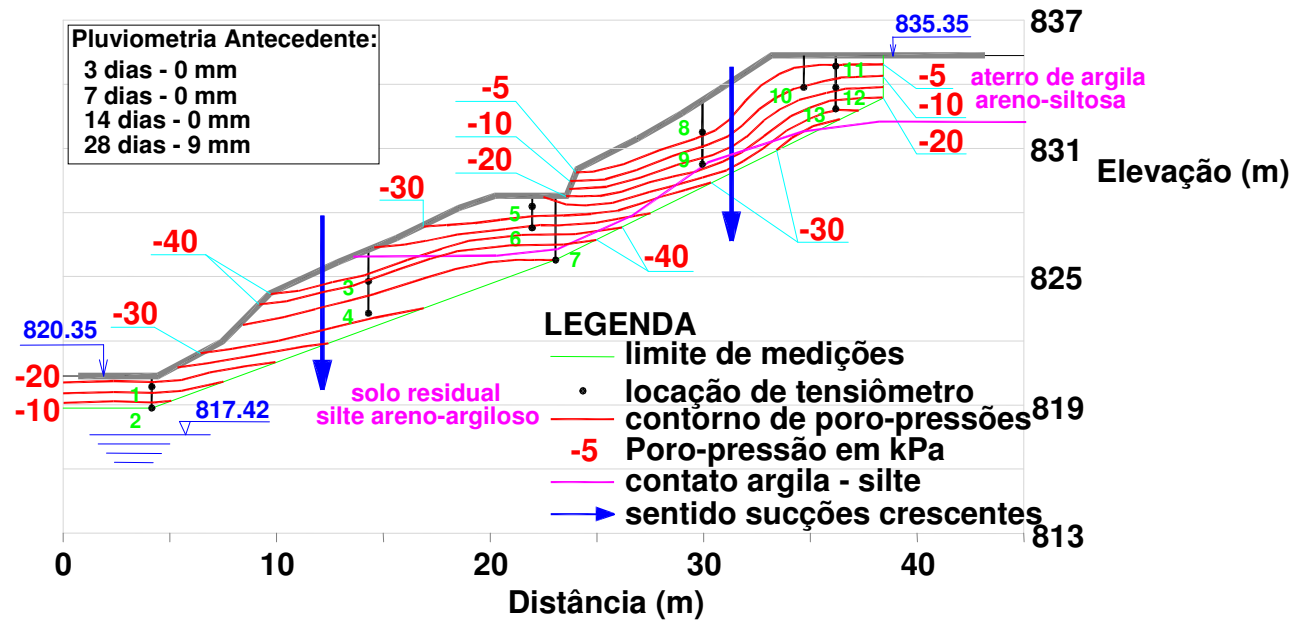

(b) Porção do talude com revestimento em argamassa, em 31/08/05

Figura 5.31: Distribuição de poro-pressões no talude em 31 de Agosto

$\mathrm{Na}$ data de 31 de agosto as poro-pressões de água foram em sua maioria menores que nos dois períodos analisados anteriormente. Isso pode ser explicado parcialmente pela menor pluviometria acumulada de 28 dias, conforme indicado na Tabela 5.9. Outro fator que deve ter contribuído é a entrada no período seco do ano, em que os períodos chuvosos são mais curtos e de menor intensidade. Os patamares de valores de poro-pressão de água foram se reduzindo ao longo do período de estiagem. 
Tabela 5.9: Poro-pressões mínimas e precipitação acumulada de 28 dias nos três eventos de maior estiagem

\begin{tabular}{|c|c|c|c|c|c|}
\hline \multirow{2}{*}{$\begin{array}{c}\text { Data do } \\
\text { Evento }\end{array}$} & \multirow{2}{*}{$\begin{array}{c}\text { Precipitação } \\
\text { Acumulada }\end{array}$} & \multicolumn{3}{|c|}{ Poro-pressões de Água Mínimas (kPa) } \\
\cline { 3 - 6 } & em 28 dias & $\begin{array}{c}\text { Argila } \\
\text { Vegetação }\end{array}$ & $\begin{array}{c}\text { Argila } \\
\text { Argamassa }\end{array}$ & $\begin{array}{c}\text { Silte } \\
\text { Vegetação }\end{array}$ & $\begin{array}{c}\text { Silte } \\
\text { Argamassa }\end{array}$ \\
\hline 20 de Maio & 28 & -45 & -30 & -45 & -30 \\
\hline 22 de Julho & 13 & -65 & -25 & -45 & -30 \\
\hline 31 de Agos & 9 & -60 & -40 & -60 & -40 \\
\hline
\end{tabular}

Verifica-se na Tabela 5.9 que a porção do talude com vegetação apresentou poropressões mínimas menores do que a revestida com argamassa, em ambos os tipos de solo, e nos três períodos de estiagem analisados. Conforme visto anteriormente a contribuição da retirada de água pelas raízes da vegetação provavelmente teve efeito importante na redução de umidade do solo e na redução da poro-pressão de água.

Comparando-se o comportamento da área com solo argiloso com o da área com solo siltoso, a 1,5 m de profundidade, na porção com vegetação verifica-se que a redução da poro-pressão de água na superfície do terreno se estende até profundidades maiores no silte, $50 \mathrm{kPa}$ (linha 4 - tensiômetro $\mathrm{C}$ ), do que na argila, $11 \mathrm{kPa}$ (linha 1 - tensiômetro L). Provavelmente, isso se deve à maior permeabilidade do silte em comparação com a da argila.

Quando ocorreram as mínimas poro-pressões de água do período de monitoramento, aproximadamente $-60 \mathrm{kPa}$, a argila manteve-se saturada (Fig. 4.24) e o silte apresentou grau de saturação igual a 55 \% (Fig. 4.25). E o coeficiente de

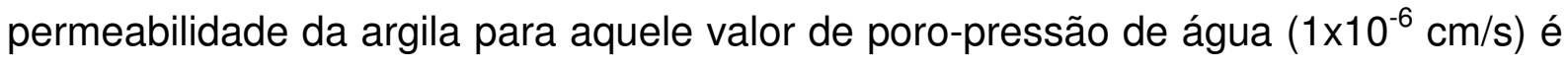
menor que o coeficiente de permeabilidade do silte $\left(3 \times 10^{-5} \mathrm{~cm} / \mathrm{s}\right)$, conforme pode ser observado na Figura 4.26.

Conforme se verificou anteriormente, o aumento da sucção foi influenciado pelos gradientes de potencial hidráulico aplicado pelas raízes da vegetação, na porção do 
talude onde há vegetação. O fluxo de água foi preponderantemente de cima para baixo.

A tendência da área com vegetação apresentar menor poro-pressão de água nos períodos de estiagem do que a porção com argamassa foi confirmada para ambos os tipos de solo. As leituras de poro-pressão de água na área com vegetação foram em média -10 kPa menores do que na porção com argamassa, após períodos de estiagem, considerando as três profundidades instrumentadas.

\subsubsection{Períodos chuvosos}

\section{Distribuição de poro-pressão de água no talude em 1ㅇ de fevereiro}

Em $1^{\circ}$ de Fevereiro os registros no solo argiloso (Linha 3) indicaram valores maiores de poro-pressão de água, entre $-3 \mathrm{kPa}$ e $-6 \mathrm{kPa}$, na porção com vegetação, do que na porção com argamassa, $-12 \mathrm{kPa}$, conforme se observa na Figura 5.32. No solo siltoso (Linha 4) os registros indicaram também valores maiores de poro-pressão de água, -15 kPa, na porção com vegetação, do que na porção com argamassa, entre $18 \mathrm{kPa}$ e $-21 \mathrm{kPa}$. Isso indica que o revestimento de argamassa provocou uma redução na infiltração de água de chuva no solo, em comparação com o solo recoberto com vegetação, por meio do aumento do "run-off" na porção argamassada.

Por outro lado, esse fato não foi observado na linha 1, crista do talude, onde as poro-pressões de água foram maiores na porção com revestimento em argamassa (entre $-6 \mathrm{kPa}$ e $+12 \mathrm{kPa}$ ) do que em vegetação (entre $0 \mathrm{kPa}$ e $+3 \mathrm{kPa}$ ). Observou-se freqüentemente a presença de um lençol freático suspenso na crista do talude. Por ser uma área plana, parece haver um abastecimento do nível freático constante nos períodos chuvosos, talvez por efeito de água empoçada nas áreas adjacentes, próximo da rua Cinira Polônio, indicada na Figura 3.3. E possivelmente também pela permeabilidade horizontal da argila ser maior que a vertical pode haver um fluxo de água na região da crista do talude em direção à face do talude, mantendo a região com elevadas poro-pressões de água. 
$\mathrm{Na}$ linha 5, pé do talude, a porção com revestimento em argamassa fica em cota inferior à da porção em vegetação, e portanto mais próximo do nível d'água no terreno, o que influencia as poro-pressões de água junto à superfície do terreno.

\begin{tabular}{|c|c|c|}
\hline Tens. & $\mathbf{u}(\mathbf{k P a})$ & $\mathbf{h}_{\mathbf{T}}(\mathbf{m})$ \\
\hline$A$ & -14 & $-0,4$ \\
\hline$B$ & -14 & $-1,4$ \\
\hline$C$ & -16 & 3,5 \\
\hline$D$ & - & - \\
\hline E & -4 & 8,6 \\
\hline F & -3 & 7,7 \\
\hline$G$ & -10 & 5,5 \\
\hline$H$ & -2 & 10,7 \\
\hline I & 3 & 9,1 \\
\hline J & -1 & 15,1 \\
\hline$L$ & 3 & 14,5 \\
\hline$M$ & 2 & 12,2 \\
\hline
\end{tabular}

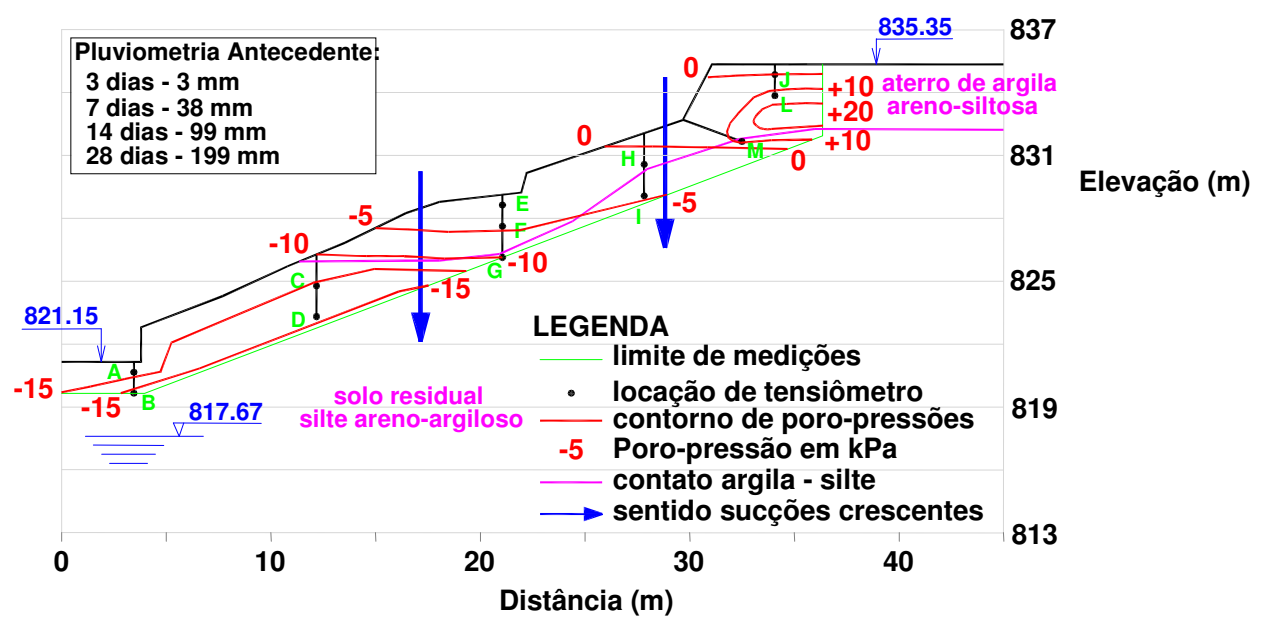

(a) Porção do talude com revestimento em vegetação, em 01/02/05

\begin{tabular}{|c|c|c|}
\hline Tens. & $\mathbf{u}(\mathbf{k P a})$ & $\mathbf{h}_{\mathbf{T}} \mathbf{( m )}$ \\
\hline 1 & $-\mathbf{1 1}$ & $-\mathbf{0 , 1}$ \\
\hline 2 & $-\mathbf{7}$ & $\mathbf{- 0 , 7}$ \\
\hline 3 & $-\mathbf{2 0}$ & $\mathbf{3 , 9}$ \\
\hline 4 & $-\mathbf{2 0}$ & $\mathbf{2 , 4}$ \\
\hline 5 & $-\mathbf{8}$ & $\mathbf{8 , 6}$ \\
\hline 6 & $\mathbf{- 1 3}$ & $\mathbf{7 , 1}$ \\
\hline 7 & $\mathbf{- 1 2}$ & $\mathbf{5 , 7}$ \\
\hline 8 & $-\mathbf{4}$ & $\mathbf{1 2 , 5}$ \\
\hline 9 & $-\mathbf{5}$ & $\mathbf{1 0 , 9}$ \\
\hline 10 & $\mathbf{1}$ & $\mathbf{1 5 , 1}$ \\
\hline 11 & $\mathbf{- 3}$ & $\mathbf{1 5 , 7}$ \\
\hline 12 & $\mathbf{6}$ & $\mathbf{1 5 , 6}$ \\
\hline 13 & $\mathbf{1 2}$ & $\mathbf{1 5 , 2}$ \\
\hline
\end{tabular}

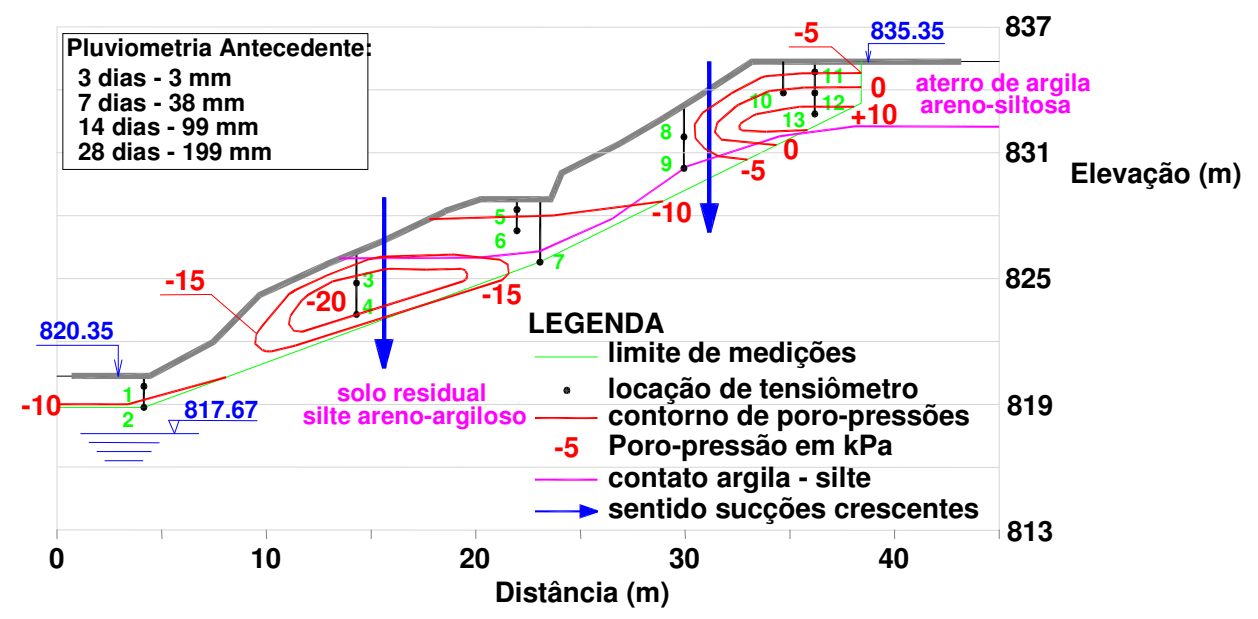

(b) Porção do talude com revestimento em argamassa, em 01/02/05

Figura 5.32: Distribuição de poro-pressões no talude em $1^{\circ}$ de Fevereiro

As flechas apresentadas na Figura 5.32 indicam o sentido dos menores potenciais hidráulicos totais. Flechas apontadas para baixo indicam o fluxo de água nessa direção. 


\section{Distribuição de poro-pressão de água no talude em 12 de abril}

Em 12 de Abril os registros no solo argiloso (Linha 3) indicaram valores maiores de poro-pressão de água, entre $-3 \mathrm{kPa}$ e $-9 \mathrm{kPa}$, na porção com vegetação, do que na porção com argamassa, $-10 \mathrm{kPa}$ a $-20 \mathrm{kPa}$,conforme se observa na Figura 5.33.

\begin{tabular}{|c|c|c|}
\hline Tens. & $\mathbf{u}(\mathbf{k P a})$ & $\mathbf{h}_{\mathbf{T}}(\mathbf{m})$ \\
\hline$A$ & -7 & 0,3 \\
\hline $\mathrm{B}$ & -17 & $-1,7$ \\
\hline $\mathrm{C}$ & -16 & 3,5 \\
\hline $\mathrm{D}$ & -15 & 2,2 \\
\hline $\mathrm{E}$ & -9 & $\mathbf{8 , 1}$ \\
\hline $\mathrm{F}$ & -4 & $\mathbf{7 , 6}$ \\
\hline $\mathrm{G}$ & -15 & 5,0 \\
\hline $\mathrm{H}$ & -3 & 10,6 \\
\hline $\mathrm{I}$ & -1 & 9,3 \\
\hline $\mathrm{J}$ & -2 & 15,0 \\
\hline $\mathrm{L}$ & 0 & 14,2 \\
\hline $\mathrm{M}$ & 0 & 12,0 \\
\hline
\end{tabular}

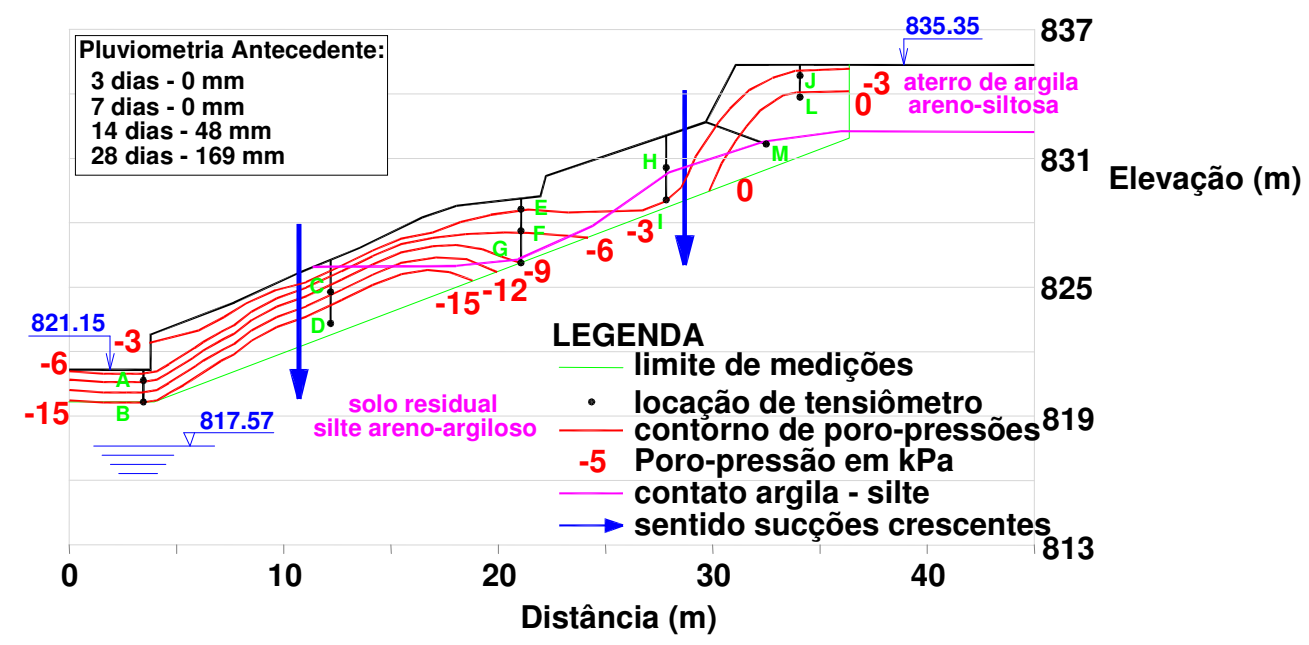

(a) Porção do talude com revestimento em vegetação, em 12/04/05

\begin{tabular}{|c|c|c|}
\hline Tens. & $\mathbf{u} \mathbf{~ ( k P a )}$ & $\mathbf{h}_{\mathbf{T}} \mathbf{( m )}$ \\
\hline 1 & $\mathbf{- 1 5}$ & $\mathbf{- 0 , 5}$ \\
\hline 2 & $\mathbf{4}$ & $\mathbf{0 , 4}$ \\
\hline 3 & $\mathbf{- 1 6}$ & $\mathbf{4 , 3}$ \\
\hline 4 & $\mathbf{- 1 1}$ & $\mathbf{3 , 3}$ \\
\hline 5 & $\mathbf{- 1 8}$ & $\mathbf{7 , 6}$ \\
\hline 6 & $\mathbf{- 2 2}$ & $\mathbf{6 , 2}$ \\
\hline 7 & $\mathbf{- 2 5}$ & $\mathbf{4 , 3}$ \\
\hline 8 & $\mathbf{- 3}$ & $\mathbf{1 2 , 6}$ \\
\hline 9 & $\mathbf{- 6}$ & $\mathbf{1 0 , 8}$ \\
\hline 10 & $\mathbf{0}$ & $\mathbf{1 5 , 0}$ \\
\hline 11 & $-\mathbf{4}$ & $\mathbf{1 5 , 6}$ \\
\hline 12 & $\mathbf{1}$ & $\mathbf{1 5 , 1}$ \\
\hline 13 & $\mathbf{7}$ & $\mathbf{1 4 , 7}$ \\
\hline
\end{tabular}

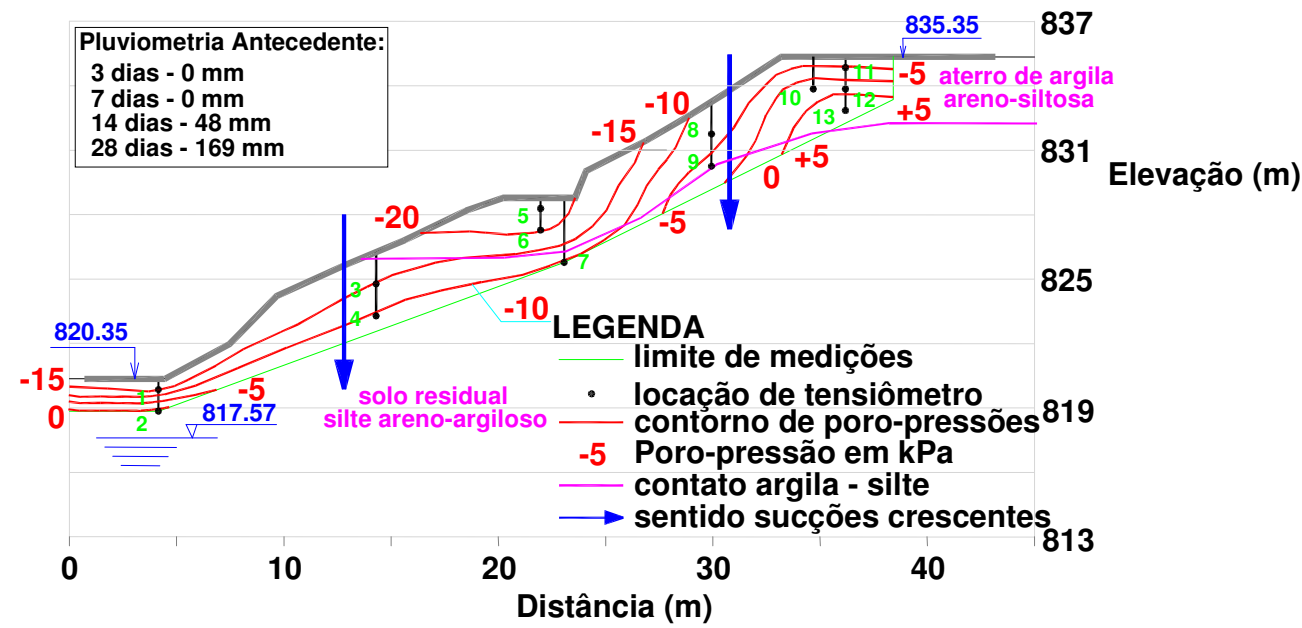

(b) Porção do talude com revestimento em argamassa, em 12/04/05

Figura 5.33: Distribuição de poro-pressões no talude em 12 de Abril

No solo siltoso (Linha 4) os registros indicaram também valores maiores de poropressão de água, $-3 \mathrm{kPa}$ a $-15 \mathrm{kPa}$, na porção com vegetação, do que na porção com argamassa, entre $-10 \mathrm{kPa}$ e $-15 \mathrm{kPa}$, confirmado as observações feitas acima. 
Sendo assim, os resultados das linhas 1 e 5 são divergentes aos demais conforme comentado acima.

\section{Distribuição de poro-pressão de água no talude em 25 de maio}

Em 25 de Maio os registros no solo argiloso (Linha 3) indicaram valores maiores de poro-pressão de água, entre $+10 \mathrm{kPa}$ e $-40 \mathrm{kPa}$, na porção com vegetação, do que na porção com argamassa, $-25 \mathrm{kPa}$ a $-30 \mathrm{kPa}$, Figura 5.34.

\begin{tabular}{|c|c|c|}
\hline Tens. & $\mathbf{u}(\mathbf{k P a})$ & $\mathbf{h}_{\mathbf{T}}(\mathbf{m})$ \\
\hline$A$ & -4 & 0,6 \\
\hline$B$ & -22 & $-2,2$ \\
\hline$C$ & -4 & 4,7 \\
\hline$D$ & -27 & 0,9 \\
\hline E & -39 & 5,0 \\
\hline F & 0 & 8,0 \\
\hline$G$ & 14 & 7,9 \\
\hline$H$ & -1 & 10,8 \\
\hline I & -2 & 9,2 \\
\hline$J$ & 1 & 15,3 \\
\hline L & 6 & 14,8 \\
\hline$M$ & -3 & 11,7 \\
\hline
\end{tabular}

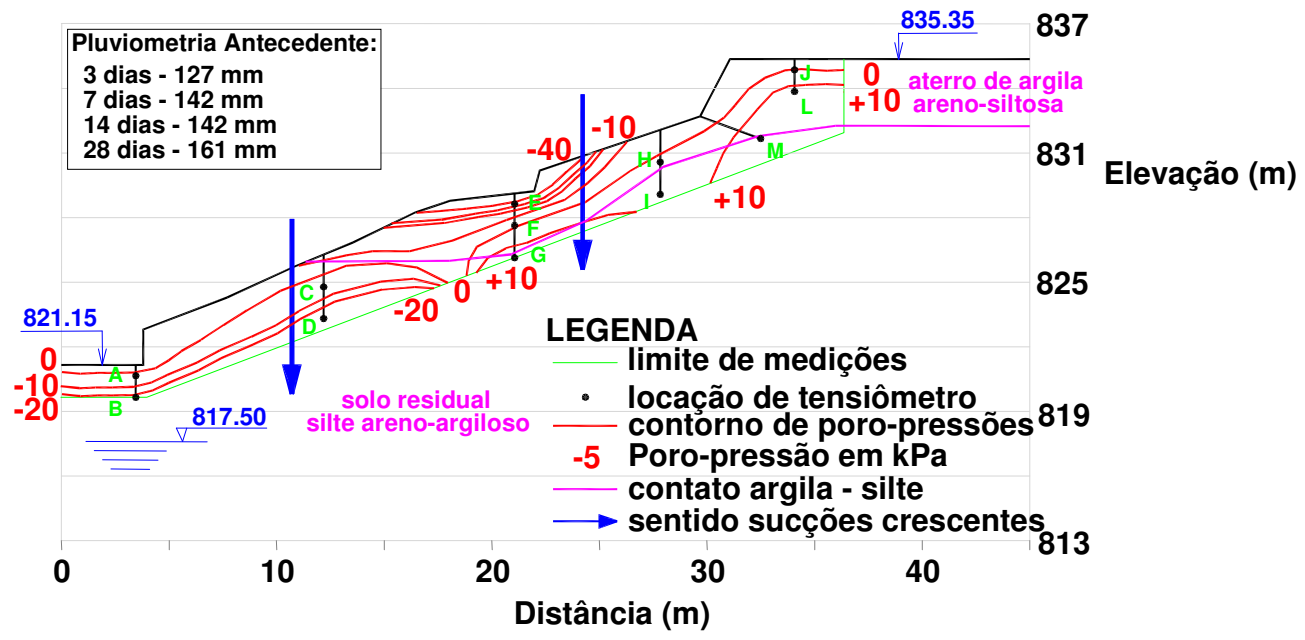

(a) Porção do talude com revestimento em vegetação, em 25/05/05

\begin{tabular}{|c|c|c|}
\hline Tens. & $\mathbf{u}(\mathbf{k P a})$ & $\mathbf{h}_{\mathbf{T}} \mathbf{( m )}$ \\
\hline 1 & $\mathbf{- 1 6}$ & $-\mathbf{0 , 6}$ \\
\hline 2 & $-\mathbf{8}$ & $-\mathbf{0 , 8}$ \\
\hline 3 & $\mathbf{- 2 9}$ & $\mathbf{2 , 9}$ \\
\hline 4 & $\mathbf{- 2 7}$ & $\mathbf{1 , 6}$ \\
\hline 5 & $\mathbf{- 2 7}$ & $\mathbf{6 , 6}$ \\
\hline 6 & $\mathbf{- 2 6}$ & $\mathbf{5 , 7}$ \\
\hline 7 & $\mathbf{- 2 6}$ & $\mathbf{4 , 2}$ \\
\hline 8 & $\mathbf{2}$ & $\mathbf{1 3 , 1}$ \\
\hline 9 & $\mathbf{1}$ & $\mathbf{1 1 , 5}$ \\
\hline 10 & $\mathbf{0}$ & $\mathbf{1 5 , 0}$ \\
\hline 11 & $\mathbf{4}$ & $\mathbf{1 6 , 4}$ \\
\hline 12 & $\mathbf{1 3}$ & $\mathbf{1 6 , 3}$ \\
\hline 13 & $\mathbf{1}$ & $\mathbf{1 4 , 1}$ \\
\hline
\end{tabular}

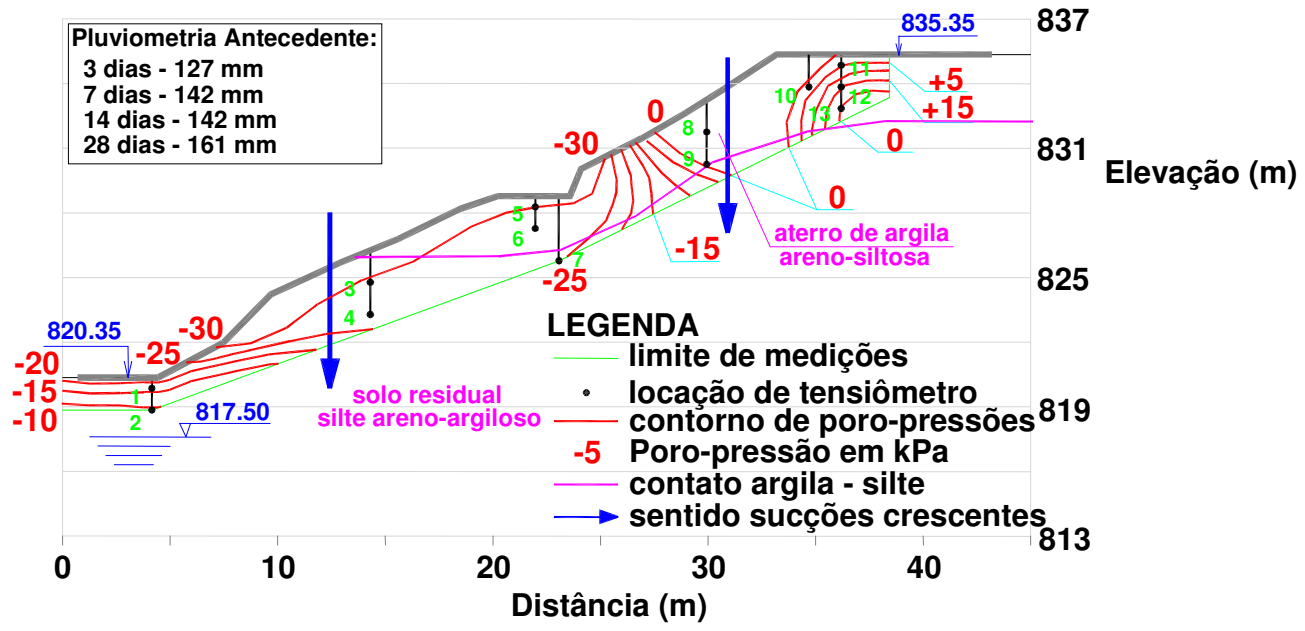

(b) Porção do talude com revestimento em argamassa, em 25/05/05

Figura 5.34: Distribuição de poro-pressões no talude em 25 de Maio 
A porção do talude revestida com argamassa apresentou poro-pressões máximas menores do que a revestida com vegetação, em ambos os tipos de solo e nos três períodos chuvosos analisados. Considerando que a permeabilidade da argamassa é menor que a do solo siltoso explica-se menores poro-pressões na porção revestida com argamassa e solo siltoso pela redução da infiltração de água no solo.

No solo siltoso (Linha 4) os registros indicaram também valores maiores de poropressão de água, $0 \mathrm{kPa}$ a $-20 \mathrm{kPa}$, na porção com vegetação, do que na porção com argamassa, $-30 \mathrm{kPa}$, confirmando novamente os resultados anteriores. Porém, as linhas 1 e 5 apresentam resultados divergentes, conforme descrito anteriormente.

\subsubsection{Conclusões sobre resposta hidrológica do talude}

De maneira geral os tensiômetros na área experimental apresentaram leituras coerentes com as precipitações, registraram elevação de poro-pressão de água nos dias chuvosos ou nos dias subseqüentes aos dias chuvosos, e redução ou manutenção de poro-pressões de água nos períodos de estiagem.

\subsubsection{Comparação entre tipos de revestimentos}

\section{Períodos de estiagem do ano}

A porção do talude com vegetação apresentou ao final dos períodos de estiagem menor poro-pressão de água média do que a porção do talude revestida com argamassa. Pode-se explicar a diferença de comportamento por meio de gradientes de potencial hidráulico aplicados pelas raízes da vegetação (capim) que retiram água do solo na porção vegetada, o que não ocorreu na porção do talude revestida com argamassa.

Poderia se supor que as menores poro-pressões de água na porção com vegetação seriam decorrentes do efeito da evaporação de água, o que não teria ocorrido no solo revestido com argamassa. Isto é, a argamassa teria impedido a evaporação de 
água do solo. Esse efeito não ocorreu no solo argiloso, pois a argila permaneceu saturada por todo o período de monitoramento e, portanto não houve fluxo de ar/vapor d'água através de seus poros, e não poderia haver redução de poropressão de água por meio da evaporação no solo argiloso. No solo siltoso é possível que tenha ocorrido evaporação.

Conclui-se que ambos os solos revestidos com vegetação apresentaram reduções de poro-pressão de água nos períodos de estiagem por efeito da transpiração. Esse efeito, provocado por gradientes de potencial hidráulico aplicados pelas raízes da vegetação foi tanto maior quanto menor a profundidade analisada. Isso se deve principalmente à proximidade das raízes que têm comprimento reduzido.

\section{Períodos chuvosos do ano}

A porção do talude revestida com argamassa apresentou em média poro-pressões de água pouco menores após períodos chuvosos do que a porção com vegetação. O revestimento de argamassa provavelmente provocou uma redução na infiltração de água de chuva no solo, em comparação com o revestimento vegetal que a reteve. O "run-off" na porção argamassada foi maior do que na porção com vegetação provavelmente por que o tratamento regularizou a superfície do talude, reduzindo os pontos de acúmulo de água.

\subsubsection{Comparação entre tipos de solos}

\section{Períodos de estiagem do ano}

O silte apresentou em média menor poro-pressão de água ao final dos períodos de estiagem analisados do que a argila. Em função de sua maior permeabilidade o silte provavelmente apresentou maior fluxo de água para o interior do maciço durante os períodos secos.

Foi registrada uma exceção onde ocorreu menor poro-pressão de água na argila do que no silte na porção do talude com vegetação a meio metro de profundidade. Provavelmente esse fato ocorreu devido ao local sombreado e com escassa 
vegetação onde foram instalados os tubos tensiométricos no silte, e por efeito de proximidade com o nível d'água do terreno, na linha 5.

\section{Períodos chuvosos do ano}

Assim como nos períodos de estiagem, após períodos chuvosos o solo siltoso apresentou menores poro-pressões de água do que o solo argiloso.

A elevação da poro-pressão de água no solo siltoso ao longo dos períodos chuvosos analisados foi praticamente igual à elevação no solo argiloso, em média $1 \mathrm{kPa}$ maior. Com maior permeabilidade e com maiores gradientes de potencial hidráulico (maiores gradientes de potencial de pressão) o solo siltoso provavelmente apresentou maior fluxo de água para o interior do maciço do que o solo argiloso. Esse fato não gerou comportamento diferenciado na elevação das poro-pressões de água entre os solos. Esse fato talvez pudesse estar associado a variações de poropressões de água causadas por outro fenômeno, que não o fluxo de água, como por exemplo, a transferência de pressão através da água intersticial.

\subsubsection{Tabela resumo das conclusões}

Apresenta-se a seguir a Tabela 5.10 contendo resumo das conclusões sobre o monitoramento do talude experimental. Constatou-se que o solo siltoso apresentou poro-pressões de água menores que o solo argiloso ao longo do período de nove meses de monitoramento, em ambos os tipos de revestimento; que nos períodos de estiagem a porção do talude com vegetação apresentou menores poro-pressões de água do que a porção revestida com argamassa; e que nos períodos chuvosos o contrário foi registrado, isto é, a porção do talude revestida com argamassa apresentou menores poro-pressões de água do que a porção com vegetação. 
Tabela 5.10: Resumo das conclusões sobre o monitoramento do talude experimental, com indicação dos tipos de revestimento e solo que apresentaram menor poro-pressão de água

\begin{tabular}{|c|c|c|}
\hline \multirow{2}{*}{$\begin{array}{c}\text { Períodos de } \\
\text { Estiagem }\end{array}$} & Revestimento & Vegetação < Argamassa \\
\hline & Solo & Silte $<$ Argila \\
\hline \multirow{2}{*}{$\begin{array}{l}\text { Períodos } \\
\text { Chuvosos }\end{array}$} & Revestimento & Argamassa < Vegetação \\
\hline & Solo & Silte $<$ Argila \\
\hline
\end{tabular}




\section{ANÁLISES DE ESTABILIDADE DE TALUDES}

Serão apresentados a seguir resultados de análises de estabilidade de talude que indicam o efeito do tipo do revestimento superficial na alteração do perfil de poropressão de água, ao longo do ano, e conseqüentemente na estabilidade do talude monitorado. Além disso, será analisado o efeito das variações sazonais de poropressão de água na estabilidade do talude.

\subsection{Estimativa da distribuição de poro-pressão de água em todo o maciço}

São apresentadas a seguir estimativas das distribuições de poro-pressão de água no talude monitorado até o nível d'água estimado, nas datas em que as leituras de poro-pressão atingiram seus maiores (1ํำ de fevereiro) e menores valores (31 de agosto) durante o período de monitoramento, nas porções do talude revestidas em argamassa e vegetação.

As distribuições de poro-pressão de água apresentadas anteriormente (Figura 5.32 $1^{\circ}$ de fevereiro) e (Figura 5.31 - 31 de agosto) foram feitas com base nas leituras dos tensiômetros e apenas até 3,0 m de profundidade. As distribuições de poro-pressão de água apresentadas a seguir são estimativas da distribuição ao longo de todo o maciço, inclusive a localização do nível d’água do terreno.

O objetivo de se fazer essas estimativas é obter distribuições de poro-pressões de água no talude experimental com as quais se possam fazer cálculos de estabilidade para as máximas e mínimas poro-pressões obtidas durante o período de monitoramento, em ambas as porções do talude, argamassada e vegetada, e comparar-se o efeito do revestimento superficial na estabilidade do talude.

A posição do nível d'água no terreno foi estimada a partir da cota do NA medido no pé do talude por meio do medidor de nível d'água, nas datas consideradas. A partir 
da estimativa do NA foram traçadas linhas paralelas a essa referência considerando equilíbrio estático até a aproximação das linhas de isovalores de poro-pressão de água traçadas até a profundidade instrumentada. A partir dessas duas referências, foram feitos ajustes nos traçados das linhas.

Foi considerado na determinação das linhas de isovalores de poro-pressão de água o contato entre o solo argiloso e o siltoso. Verificou-se que abaixo desse contato, isto é, no solo siltoso as poro-pressões de água crescem devido as características hidráulicas dos solos descritas anteriormente neste trabalho. É possível que a camada de argila com detritos vegetais existente entre o aterro argiloso e o solo residual siltoso, indicada na Figura 4.16, funcione como uma barreira ao fluxo de água no talude e induza à formação do nível d'água suspenso, existente na crista do talude, indicado na Figura 6.1. Esse lençol suspenso é abastecido pelo fluxo de água na crista do talude predominantemente sub-horizontal decorrente da permeabilidade horizontal da argila ser significativamente maior que a permeabilidade vertical desse solo.

Em $1^{\circ}$ de fevereiro, período chuvoso do ano, as poro-pressões de água na porção do talude com vegetação são entre $5 \mathrm{kPa}$ e $10 \mathrm{kPa}$ maiores que na porção argamassada. Exceto no pé do talude onde ocorre o inverso, provavelmente porque essa porção está em cota mais próxima do nível d'água do que a porção com vegetação. 

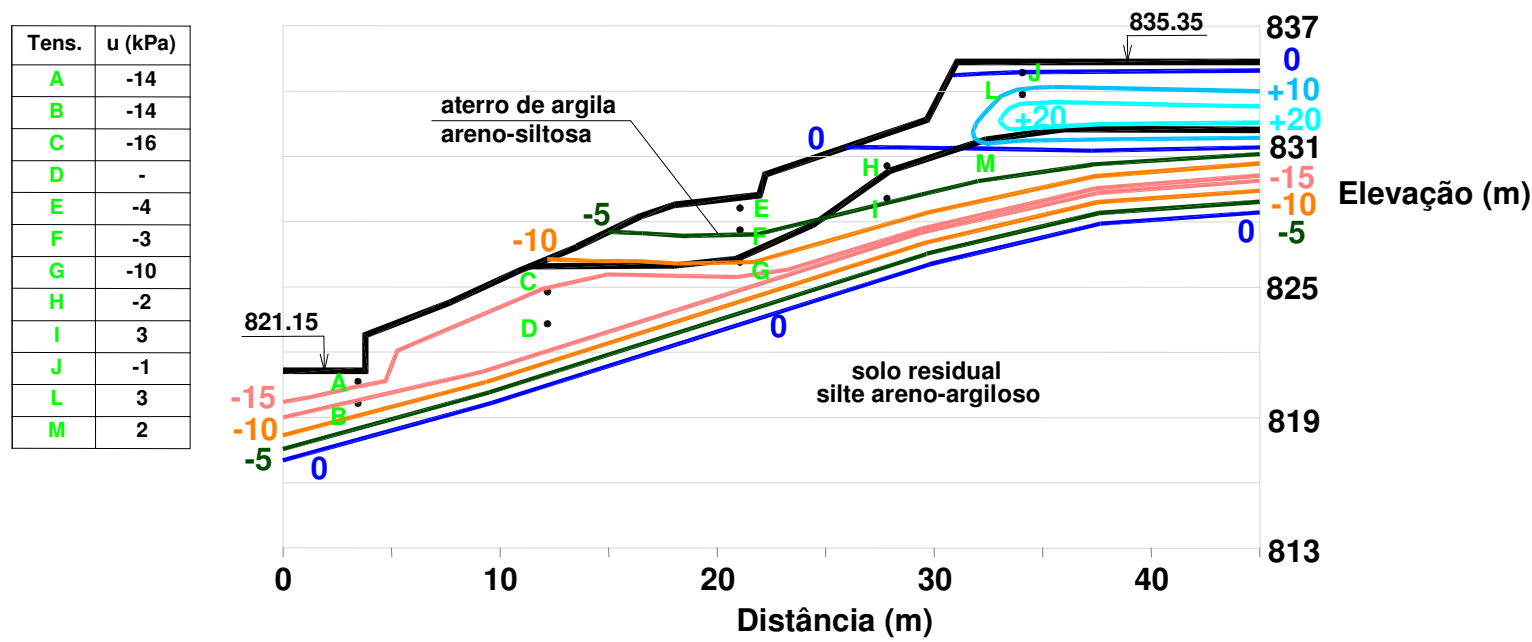

(a) Porção do talude com revestimento em vegetação, em 01/02/05
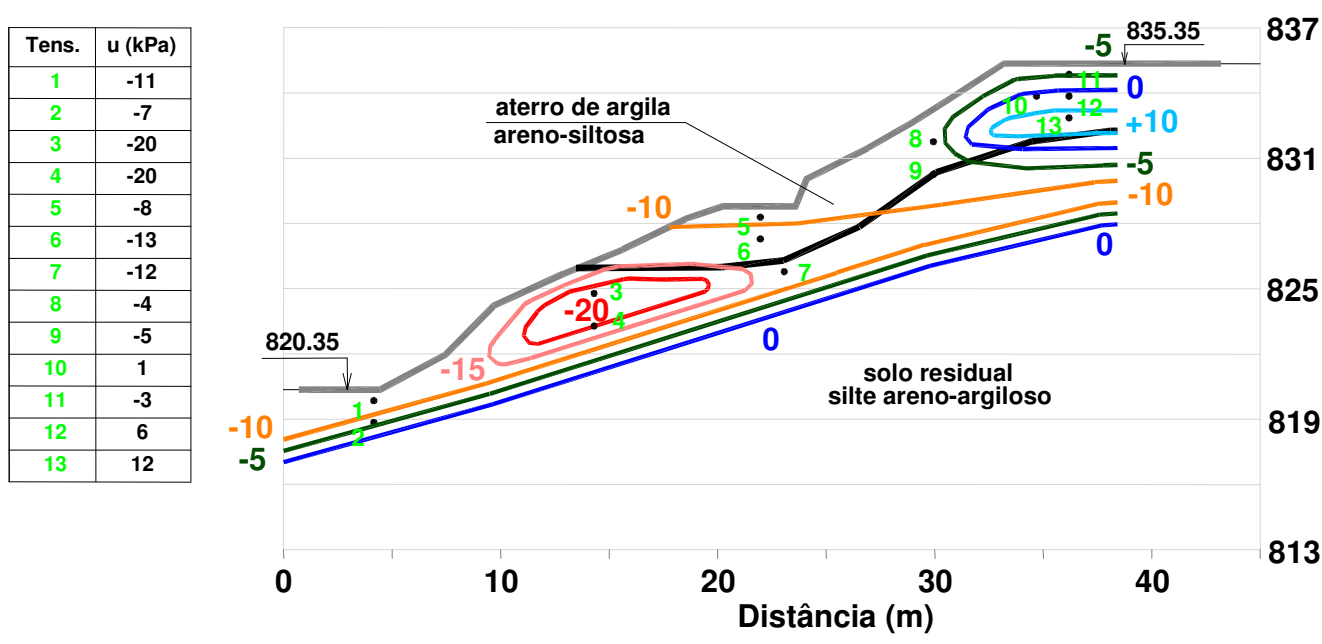

(b) Porção do talude com revestimento em argamassa, em 01/02/05

Figura 6.1: Distribuição estimada de poro-pressão de água até o nível d'água do terreno no talude, em $1^{\circ}$ de fevereiro

Em 31 de agosto, período de estiagem do ano, há uma diferença marcante nos patamares de valores de poro-pressões entre as porções do talude. O efeito da evapo-transpiração realizada pela vegetação nessa porção do talude é marcante na redução das poro-pressões de água até cerca de 2,5 $\mathrm{m}$ de profundidade no solo argiloso, e até cerca de $4 \mathrm{~m}$ de profundidade no solo siltoso. Verificou-se que no pé do talude, na porção com vegetação, o equilíbrio estático não ocorre conforme esperado. O efeito da evapo-transpiração provavelmente gera uma condição de equilíbrio com poro-pressões de água menores que a esperada. Isso pode ser 
constatado pela distância menor que um metro entre as linhas de iso-valores de 10 em $10 \mathrm{kPa}$, nessa região do talude, conforme mostra a Figura 6.2.

\begin{tabular}{|c|c|}
\hline Tens. & $\mathbf{u}(\mathbf{k P a})$ \\
\hline$A$ & -23 \\
\hline$B$ & -33 \\
\hline C & -50 \\
\hline$D$ & -39 \\
\hline E & -55 \\
\hline F & -24 \\
\hline G & -38 \\
\hline$H$ & -14 \\
\hline I & -18 \\
\hline$J$ & -64 \\
\hline L & -11 \\
\hline$M$ & -4 \\
\hline
\end{tabular}

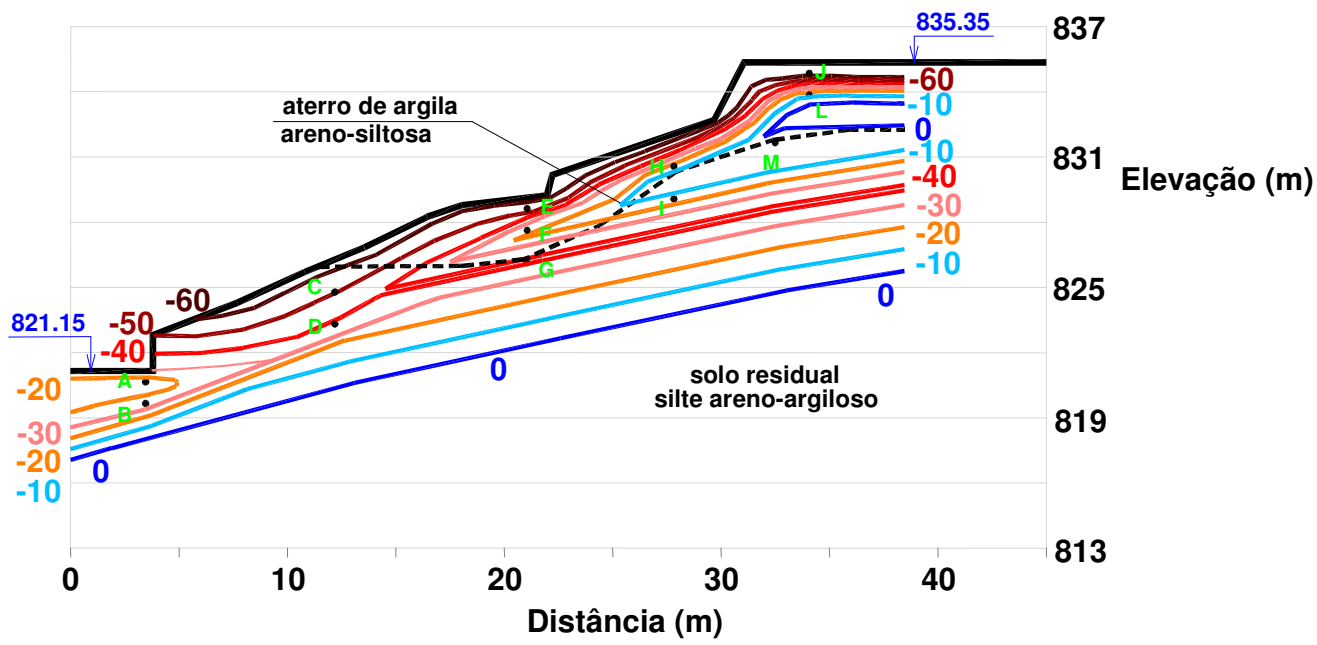

(a) Porção do talude com revestimento em vegetação, em 31/08/05
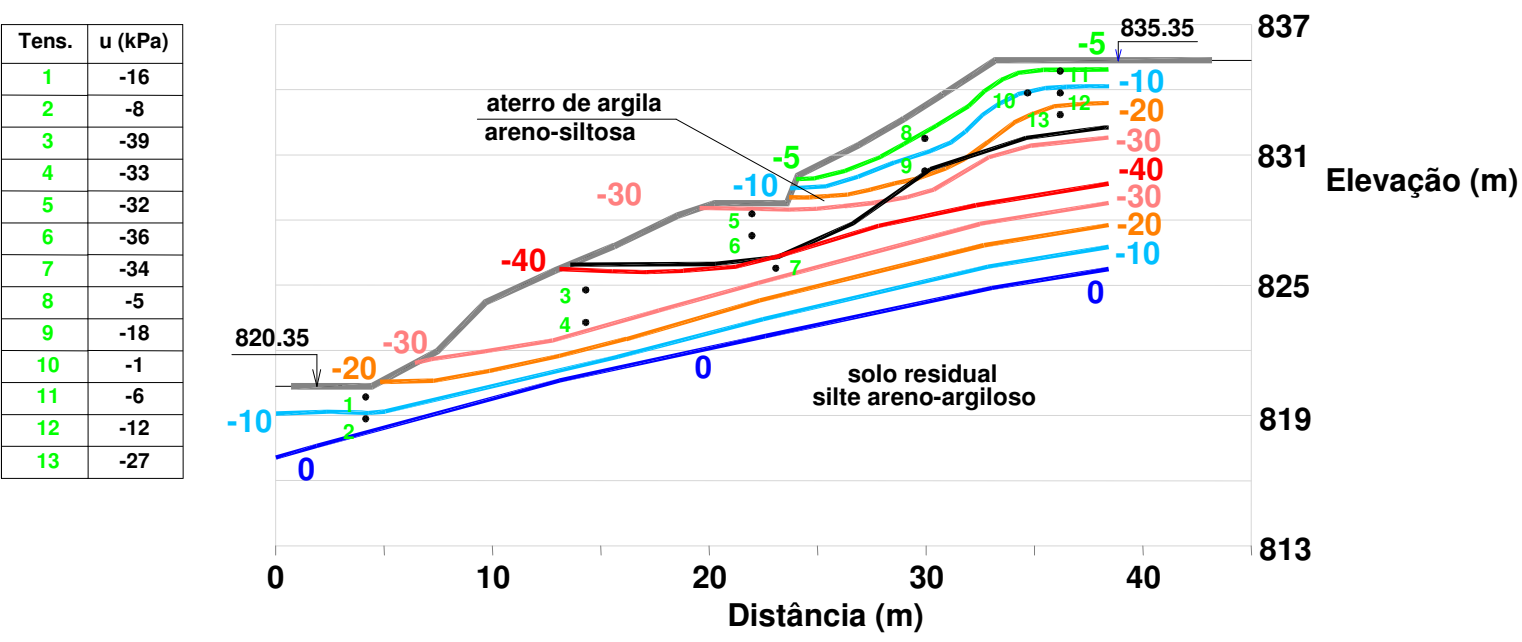

(b) Porção do talude com revestimento em argamassa, em 31/08/05

Figura 6.2: Distribuição estimada de poro-pressão de água até o nível d'água do terreno no talude, em 31 de agosto.

\subsection{Parâmetros geotécnicos}

Os parâmetros de resistência dos solos existentes no talude experimental, obtidos em ensaios de cisalhamento direto e compressão simples, são apresentados na Tabela 6.1 juntamente com os valores adotados para cada solo, que serão utilizados 
nos cálculos de estabilidade a serem apresentados a seguir. Os valores de $\phi^{b}$ indicados na tabela se referem a níveis de sucção próximos dos valores registrados no monitoramento, entre 0 e $60 \mathrm{kPa}$.

Os resultados dos ensaios de cisalhamento direto indicaram a resistência ao cisalhamento do silte em um plano imposto, diferente do plano de foliação deste solo, e os resultados dos ensaios de compressão simples indicaram a resistência ao cisalhamento do silte no plano de foliação. Com base em dados da literatura foram adotados valores para os parâmetros de resistência c' e $\phi^{\prime}$ do solo siltoso, em seu plano de foliação. Os valores adotados nos cálculos de estabilidade são valores entre os obtidos (ou adotados) para os dois tipos de ensaios, considerando que rupturas em solos com plano de foliação normalmente ocorrem parte nesse plano e parte em planos diversos dele.

Tabela 6.1: Parâmetros de resistência dos solos existentes no talude experimental

\begin{tabular}{|c|c|c|c|c|}
\hline Solo & $\begin{array}{c}\text { Parâmetros de } \\
\text { Resistência }\end{array}$ & $\begin{array}{c}\text { Cisalhamento } \\
\text { Direto }\end{array}$ & $\begin{array}{c}\text { Compressão } \\
\text { Simples }\end{array}$ & Adotados \\
\hline \multirow{3}{*}{ Silte } & $\mathrm{c}^{\prime}(\mathrm{kPa})$ & 19 & $0^{*}$ & 5 \\
\cline { 2 - 5 } & $\phi^{\prime}\left(^{\circ}\right)$ & 35 & $22^{*}$ & 25 \\
\cline { 2 - 5 } & $\phi^{b}\left(^{\circ}\right)$ & 35 & 11 & 11 \\
\hline \multirow{3}{*}{ Argila } & $\mathrm{c}^{\prime}(\mathrm{kPa})$ & 15 & $15^{\star *}$ & 15 \\
\cline { 2 - 5 } & $\phi^{\prime}\left(^{\circ}\right)$ & 31 & $31^{* *}$ & 31 \\
\cline { 2 - 5 } & $\phi^{b}\left(^{\circ}\right)$ & 36 & 38 & 36 \\
\hline
\end{tabular}

* - Valores adotados com base em dados da literatura

* - Valores adotados com base nos resultados dos ensaios de cisalhamento direto

O peso específico natural da argila é $20,5 \mathrm{kN} / \mathrm{m}^{3}$ e o do silte é $17,8 \mathrm{kN} / \mathrm{m}^{3}$.

\subsection{Análises de estabilidade do talude experimental}

Apresentam-se a seguir análises de estabilidade do talude monitorado nesta pesquisa, com o objetivo de se determinar o efeito do revestimento superficial na 
estabilidade do talude, e o efeito das variações sazonais de poro-pressão de água em sua estabilidade.

\subsubsection{Efeito das variações sazonais da poro-pressão de água na estabilidade do talude}

O efeito das variações sazonais da poro-pressão de água na estabilidade do talude monitorado é apresentado a seguir por meio da comparação dos fatores de segurança ao escorregamento nas datas de máxima e mínima poro-pressão de água, durante o período de monitoramento.

Os resultados das análises de estabilidade para a data em que foram registradas as máximas poro-pressões de água, 1ำ de fevereiro, são apresentados na Figuras 6.3, para a porção do talude com vegetação, e na Figura 6.4, para a porção do talude revestida com argamassa. Os resultados das análises de estabilidade na data de menores poro-pressões de água, 31 de agosto, são apresentados nas Figuras 6.5 e 6.6, para as porções vegetada e argamassada do talude, respectivamente.

As linhas azuis indicadas nas figuras representam os contornos de iso-valores de poro-pressão de água no talude, coerentes com as distribuições de poro-pressões de água indicadas nas Figuras 6.1 e 6.2. Conforme o manual do software Slope/W, essas linhas devem ter início e fim nas extremidades da área de trabalho, portanto pode-se ver nas Figuras 6.3 a 6.6 que as linhas de iso-valores de poro-pressão de água ultrapassam as linhas da geometria dos taludes.

Considerando a metodologia indicada acima, de inserção das linhas de iso-valores de poro-pressão de água definida pelo software utilizado, foram feitas simplificações nas indicações da distribuição de poro-pressão de água no talude em relação às distribuições apresentadas nas Figuras 6.1 e 6.2. As linhas que não tinham início e fim nas extremidades da área de trabalho tiveram seu traçado adaptado para que essa imposição fosse atendida, na simulação. Não se espera que essas simplificações gerem distorções significativas nos fatores de segurança calculados. 


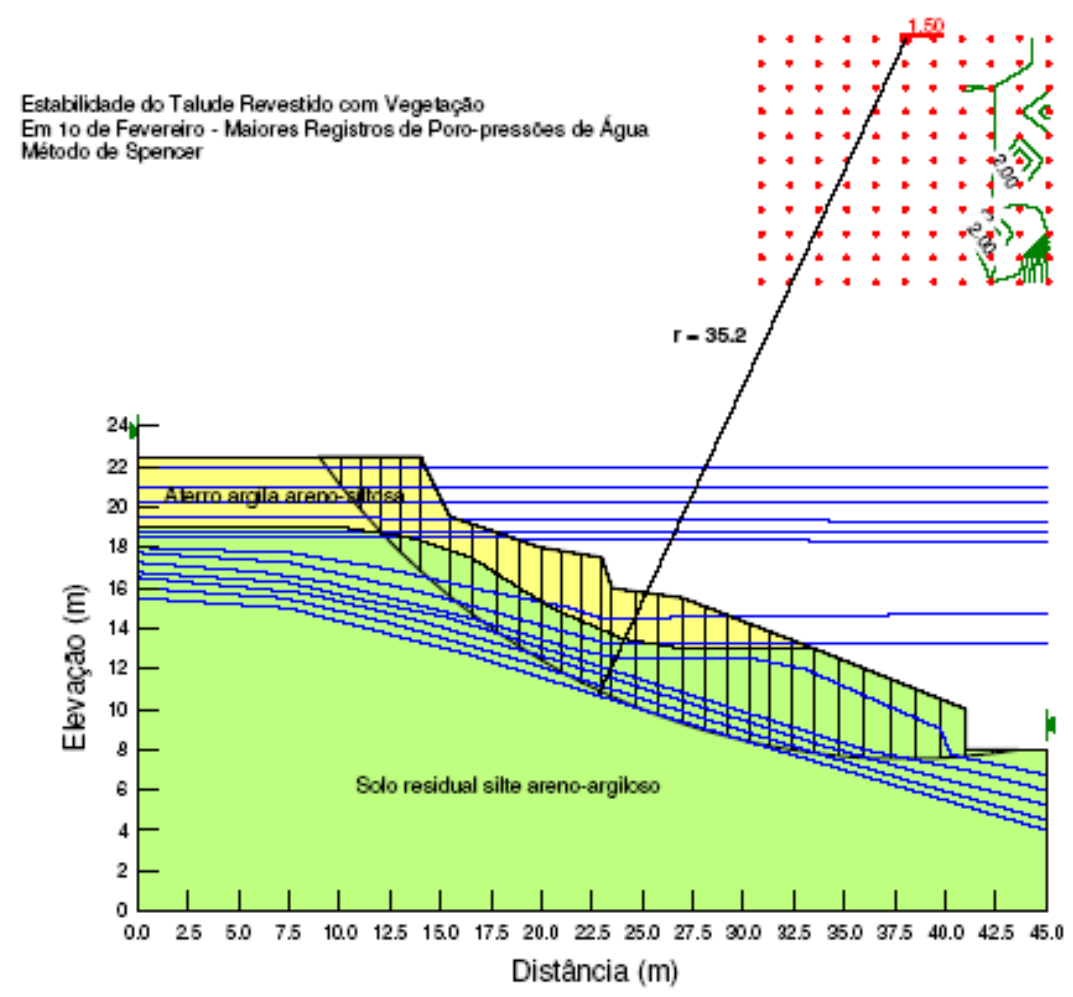

Figura 6.3: Resultado da análise de estabilidade na porção do talude com

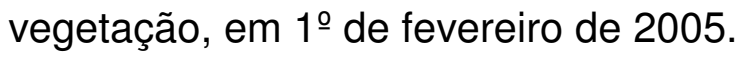

Estabilidade do Talude Revestido com Argamassa

Em 10 de Fevereiro - Maiores Registros de Poro-pressces de Água uśtodo de Spencer

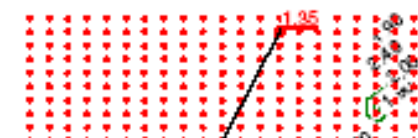

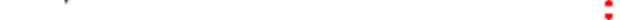

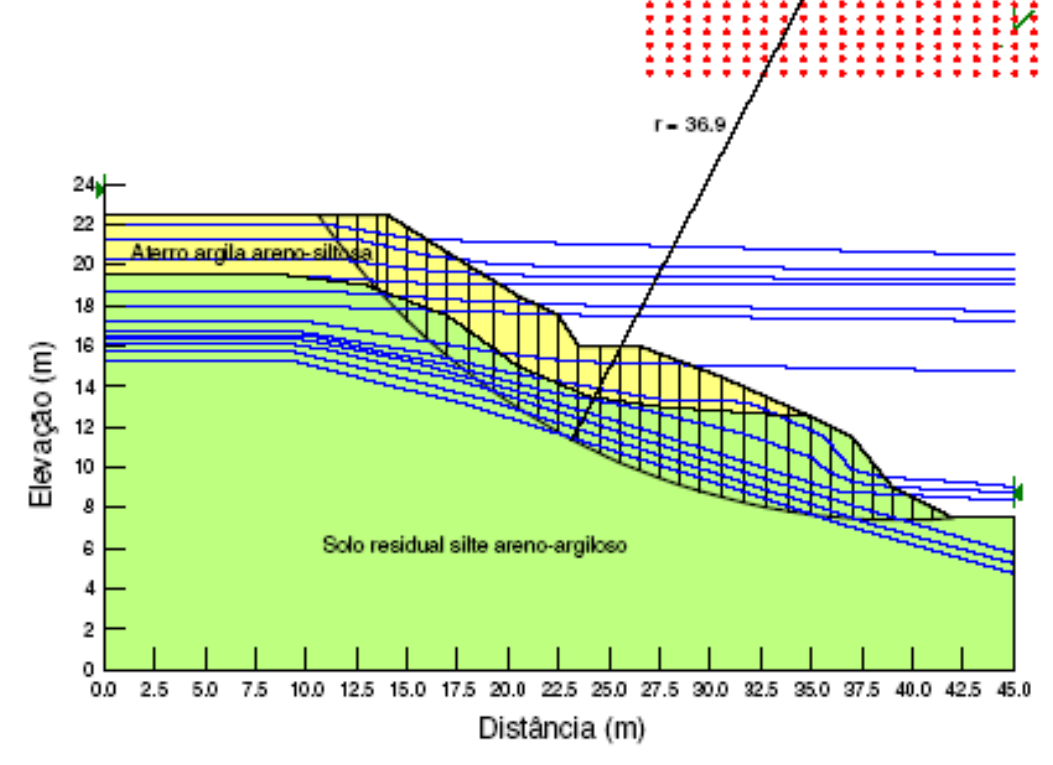

Figura 6.4: Resultado da análise de estabilidade na porção do talude revestida com argamassa, em $1^{\circ}$ de fevereiro de 2005. 
Estabilidade do Talude Revestido com Vegetaça Em 31 de Agosto - Menores Registros de Poro-pressão de Água Método de Spencer

,
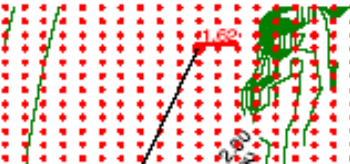

.
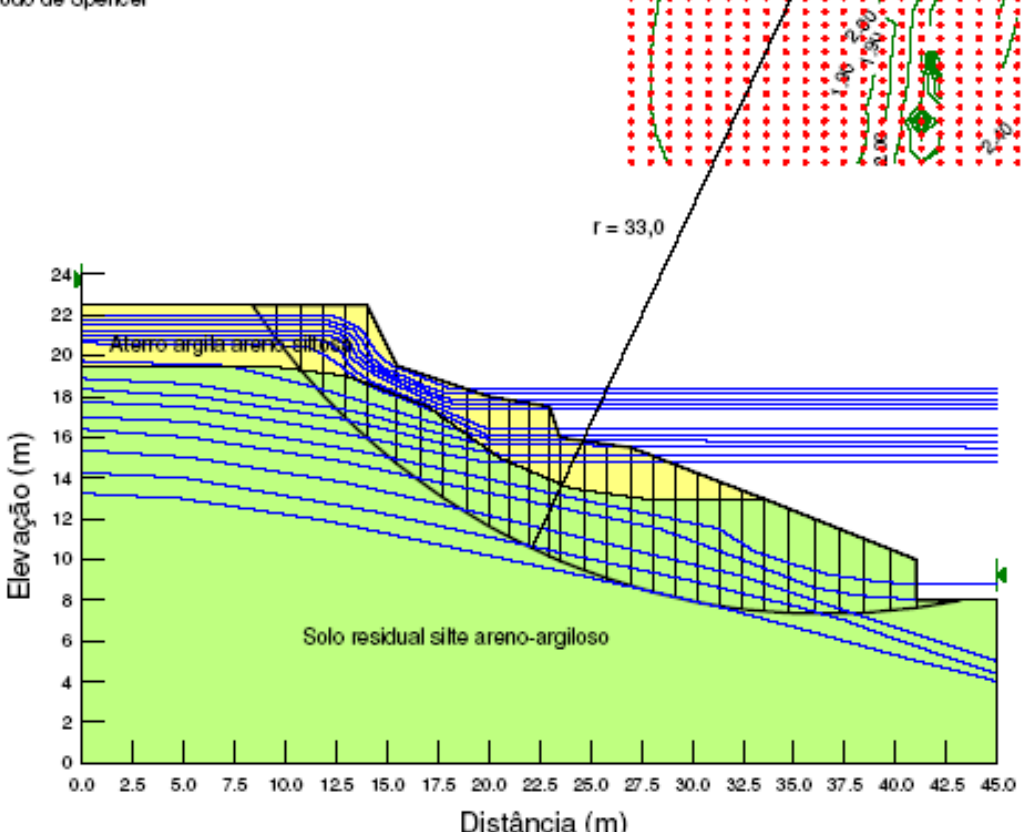

Distância $(\mathrm{m})$

Figura 6.5: Resultado da análise de estabilidade na porção do talude com vegetação, em 31 de agosto de 2005.

Estabilidade do Talude Revestido com Argamassa Em 31 de Agosto - Menores Registros de Poro-pressoes de Água Método de Spencer

$!$

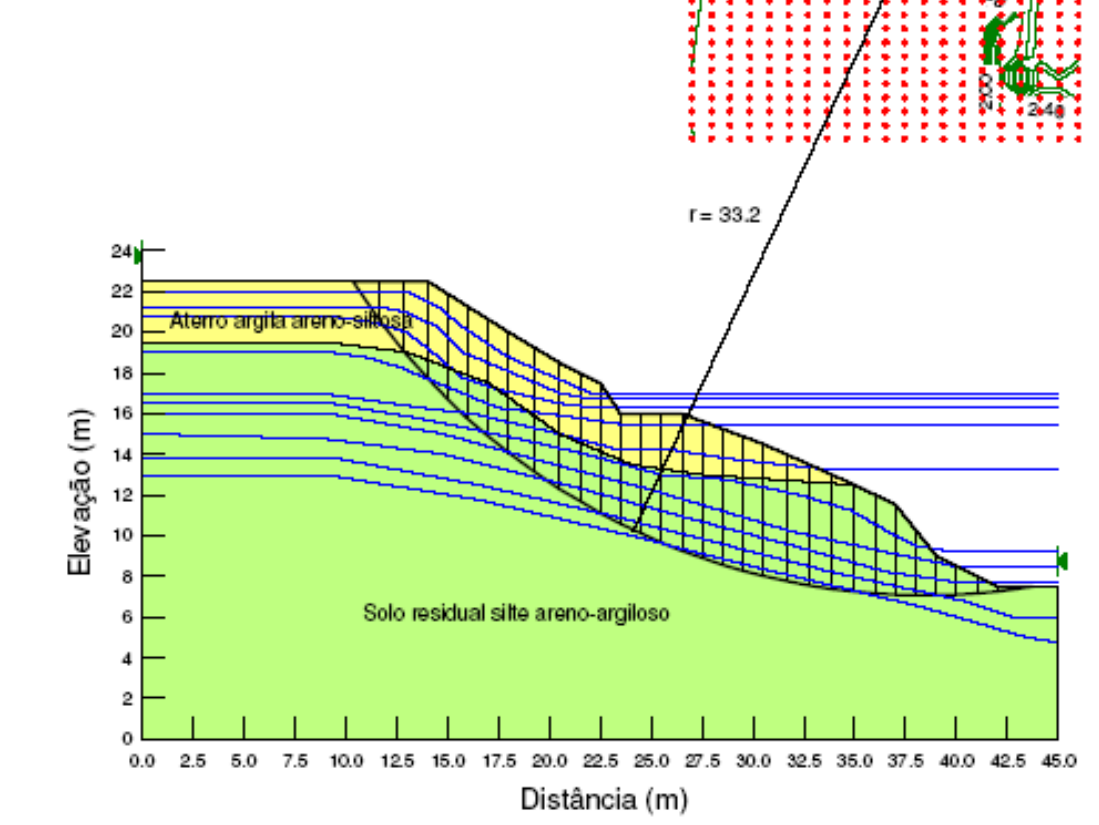

Figura 6.6: Resultado da análise de estabilidade na porção do talude revestida com argamassa, em 31 de agosto de 2005. 
Comparando-se os fatores de segurança ao escorregamento obtidos para as datas de maior e menor poro-pressões de água no talude, nas porções argamassada e com vegetação do talude, verificou-se que no período mais seco do ano o fator de segurança ao escorregamento do talude é de 7 a $8 \%$ maior do que no período mais chuvoso, conforme pode ser visto na Tabela 6.2.

Tabela 6.2: Comparação dos fatores de segurança do talude monitorado, que indica o efeito das variações sazonais de poro-pressão de água na estabilidade do talude

\begin{tabular}{|c|c|c|c|c|c|}
\hline Revestimento & Data & FS Spencer $^{*}$ & FS Bishop & FSJanbu & Variação do FS \\
\hline \multirow{2}{*}{ Vegetação } & $1^{\circ}$ de Fever & 1,50 & 1,51 & 1,40 & \multirow{2}{*}{$8 \%$} \\
\cline { 2 - 5 } & 31 de Ago & 1,62 & 1,62 & 1,51 & \\
\hline \multirow{2}{*}{ Argamassa } & $1^{\circ}$ de Fever & 1,35 & 1,35 & 1,27 & \multirow{2}{*}{$7 \%$} \\
\cline { 2 - 5 } & 31 de Ago & 1,44 & 1,44 & 1,36 & \\
\hline
\end{tabular}

* - Utilizado para análise

Os resultados apresentados acima indicam uma variação significativa no fator de segurança ao escorregamento do talude, como efeito das variações sazonais de poro-pressão de água durante o período do monitoramento, considerando que as precipitações ocorridas durante esse período foram $15 \%$ a $20 \%$ menores do que as médias históricas dos postos pluviométricos da Luz e Jd. Centenário, respectivamente, conforme apresentado anteriormente neste trabalho.

\subsubsection{Efeito do tipo do revestimento superficial na estabilidade do talude}

O efeito do tipo de revestimento superficial na estabilidade do talude monitorado é apresentado a seguir por meio da comparação dos fatores de segurança ao escorregamento em ambas as porções do talude.

Deve-se considerar que a geometria do talude na porção em que é revestido com vegetação é diferente da geometria da porção em que foi aplicada argamassa. 
Conforme se observa nas Figuras 5.2 e 5.3 a diferença entre as cotas do pé de talude na porção com vegetação $(821,15 \mathrm{~m})$ e na porção argamassada $(820,35 \mathrm{~m})$ é de $80 \mathrm{~cm}$. Sendo que a cota da crista do talude em ambas as porções é a mesma, $835,35 \mathrm{~m}$. A altura do talude na porção com vegetação é $14,2 \mathrm{~m}$ e na porção revestida com argamassa é 15,0 m. Em conseqüência disso a porção do talude revestida com argamassa apresenta fatores de segurança menores do que a porção do talude com vegetação, conforme pode ser visto na Tabela 6.4.

Considerando a impossibilidade de se comparar diretamente os fatores de segurança da porção com vegetação com os da porção com argamassa, foi feita a seguinte comparação. Foram calculados e comparados os fatores de segurança ao escorregamento do talude, em $1^{\circ}$ de fevereiro, revestido com vegetação com as poro-pressões de água registradas na porção com vegetação, com os fatores de segurança do talude revestido com vegetação com poro-pressões de água registradas na porção revestida com argamassa. O mesmo tipo de comparação foi realizado para a porção argamassada do talude. Ambas as comparações são apresentadas na Tabela 6.3.

Tabela 6.3: Comparação dos fatores de segurança do talude monitorado, em $1^{\circ}$ de fevereiro, que indica o efeito do revestimento superficial na estabilidade do talude

\begin{tabular}{|c|c|c|c|c|}
\hline $\begin{array}{l}\text { Geometria do } \\
\text { Talude Revestido } \\
\text { com }\end{array}$ & $\begin{array}{l}\text { PPA }^{*} \text { medidas } \\
\text { na porção com }\end{array}$ & FSspencer ${ }^{\star *}$ & FS Bishop & FSJanbu \\
\hline \multirow{2}{*}{ Vegetação } & Vegetação & 1,50 & 1,51 & 1,40 \\
\hline & Argamassa & 1,52 & 1,52 & 1,42 \\
\hline \multirow{2}{*}{ Argamassa } & Vegetação & 1,34 & 1,34 & 1,25 \\
\hline & Argamassa & 1,35 & 1,35 & 1,27 \\
\hline
\end{tabular}

* - Poro-pressões de água

** - Utilizado para análise 
Não se verificou efeito do revestimento superficial na estabilidade do talude na data em que foram registradas as maiores poro-pressões de água durante o monitoramento, $1^{\circ}$ de fevereiro.

$\mathrm{Na}$ Tabela 6.4 é apresentada a comparação dos fatores de segurança ao escorregamento, da mesma forma que realizado acima, para a data em que foram registradas as menores poro-pressões de água no talude durante o período de monitoramento, 31 de agosto.

Tabela 6.4: Comparação dos fatores de segurança do talude monitorado, em 31 de agosto, que indica o efeito do revestimento superficial na estabilidade do talude

\begin{tabular}{|c|c|c|c|c|}
\hline $\begin{array}{c}\text { Geometria do } \\
\text { Talude Revestido } \\
\text { com }\end{array}$ & $\begin{array}{l}\text { PPA* }^{*} \text { medidas } \\
\text { na porção com }\end{array}$ & FSspencer ${ }^{* *}$ & FS Bishop & FSJanbu \\
\hline \multirow{2}{*}{ Vegetação } & Vegetação & 1,62 & 1,62 & 1,51 \\
\hline & Argamassa & 1,61 & 1,61 & 1,52 \\
\hline \multirow{2}{*}{ Argamassa } & Vegetação & 1,43 & 1,43 & 1,34 \\
\hline & Argamassa & 1,44 & 1,44 & 1,36 \\
\hline
\end{tabular}

* - Poro-pressões de água

** - Utilizado para análise

Não pôde ser verificado efeito do revestimento superficial na estabilidade do talude na data em que foram registradas as menores poro-pressões de água durante o monitoramento, 31 de agosto. 


\section{CONCLUSÕES E RECOMENDAÇÕES PARA FUTURAS PESQUISAS}

Nesta pesquisa foi apresentado um estudo envolvendo o monitoramento de um talude em solo não saturado, com tensiômetros, medidor de nível d'água e pluviômetro. Foram realizados ensaios de laboratório com amostras dos tipos de solos existentes no talude, como caracterização, parâmetros hidráulicos e parâmetros de resistência com o intuito de que tais parâmetros servirem como base para compreensão dos resultados do monitoramento do talude, e para serem utilizados em análises de estabilidade do talude monitorado.

O presente trabalho apresenta ainda, resultados de ensaios para análise do funcionamento do tensímetro, um tipo de tensiômetro utilizado e aperfeiçoado no decorrer da pesquisa, além de outros ensaios "in situ" e em laboratório. As principais conclusões formuladas durante a pesquisa são apresentadas a seguir, inclusive aquelas relativas ao efeito do revestimento superficial na estabilidade do talude experimental, principal motivação desta pesquisa.

\subsection{Aspectos relacionados à utilização do tensímetro}

O monitoramento de poro-pressão de água no talude experimental com tensímetro digital resultou em medições coerente entre si e com as precipitações registradas durante o período. Ensaios realizados em laboratório indicaram leituras coerentes entre o tensímetro digital e um tensiômetro digital comum, confirmando sua confiabilidade como instrumento de medida de poro-pressão de água.

As vantagens da utilização desse instrumento são: a redução de custos na aquisição dos instrumentos, a redução de erros causados pela dispersão das leituras nos manômetros ou transdutores, a possibilidade de se fazer leituras tanto positivas como negativas de poro-pressão de água, e a redução de problemas operacionais como o vandalismo. Apesar de ser um instrumento simples, não há registros de sua aplicação na engenharia geotécnica, embora seja comum na aplicação agrícola. 
Durante a inserção e a retirada da agulha hipodérmica do tensímetro do interior de tubos tensiométricos ocorre perda de pressão no tubo tensiométrico. Portanto, a utilização desse instrumento deve ser feita após estudos que indiquem o tempo mínimo entre duas leituras em um tubo tensiométrico, que permita a retomada da pressão dentro do tubo. Além disso, deve ser estudado o tempo necessário para que as leituras se estabilizem no tensímetro. Esse tempo varia conforme a permeabilidade do solo e as dimensões internas do tensímetro, e influencia os principais custos de um monitoramento.

As leituras efetuadas com tensímetro analógico em laboratório apresentaram-se coerentes com as leituras efetuadas com os demais tensiômetros citados acima. As leituras efetuadas em campo com esse instrumento não se apresentaram coerentes entre si e com as precipitações registradas durante o período. A manipulação e transporte do instrumento em campo pode ter alterado a sua calibração resultando em leituras incoerentes.

\subsection{Aspectos relacionados aos ensaios de laboratório}

Os ensaios realizados com o solo argiloso areno-siltoso existente no talude experimental indicaram ser um aterro compactado com elevado peso específico natural, baixo índice de vazios, baixo índice de plasticidade, e foi classificado na carta de plasticidade como ML/CL. $O$ aterro argiloso tem origem em sedimentos fluviais da Formação São Paulo, do terciário, apresenta anisotropia com relação à permeabilidade e elevado valor de entrada de ar. Foram determinados os parâmetros de resistência efetivos e não saturados do solo a partir de ensaios de cisalhamento direto e de compressão simples, que indicaram valor incomum de $\phi^{b}$ maior do que o de $\phi^{\prime}$, para sucções menores que $60 \mathrm{kPa}$, e valor de $\phi^{b}$ menor do que o de $\phi^{\prime}$, para sucções maiores que $60 \mathrm{kPa}$.

O solo residual siltoso areno-argiloso existente no campo experimental apresenta baixo índice de vazios, baixo índice de plasticidade, e foi classificado na carta de 
plasticidade como ML. O solo residual siltoso tem origem em quartzo-mica xistos do Complexo Pilar, do Pré-cambriano, apresenta anisotropia com relação à permeabilidade e à resistência e baixo valor de entrada de ar. Há um plano de foliação, que faz cerca de $45^{\circ} \mathrm{com}$ o plano horizontal, em que a permeabilidade é maior que as permeabilidades vertical e horizontal. A resistência ao cisalhamento no plano de foliação é significativamente menor do que em outros planos quaisquer de ruptura.

\subsection{Aspectos relacionados ao ensaio de infiltração "in situ"}

As leituras de campo no Ensaio de Infiltração em Infiltrômetro de Duplo-Anel com Medição de Poro-pressão de Água registraram elevações de poro-pressão de água entre $0,4 \mathrm{kPa}$ e $6,2 \mathrm{kPa}$ até a distância horizontal de 7,5 $\mathrm{m}$ do centro dos anéis de infiltração e até a profundidade em que foram instalados instrumentos, $3,0 \mathrm{~m}$. Os maiores acréscimos de poro-pressão de água localizaram-se ao longo de uma linha que parte do centro dos anéis de infiltração e que faz cerca de $30^{\circ} \mathrm{com}$ a horizontal. Isso foi explicado pela anisotropia do solo com relação à permeabilidade.

Os resultados de simulação do ensaio de infiltração no programa Seep/W indicaram que a frente de infiltração atinge uma distância máxima na horizontal de aproximadamente $3,0 \mathrm{~m}$ e na vertical de $1,0 \mathrm{~m}$ em relação ao centro dos anéis de infiltração. $A$ análise numérica mostrou que 0 avanço da frente de infiltração não provoca variação de poro-pressão de água nos tensiômetros situados a 7,5m do centro do ensaio, e nos tensiômetros instalados a 1,5m e 3,0 $\mathrm{m}$ de profundidade.

Comparando-se os resultados obtidos em campo com os resultados da análise numérica, verificou-se que o aumento de poro-pressão de água no solo, medido em campo, atinge profundidade e distância na horizontal maiores do que o verificado na simulação em computador. Propõe-se explicar essa divergência de resultados considerando que a variação da poro-pressão de água ocorreria por meio de outro fenômeno, além do fluxo de água calculado na análise numérica. 


\subsection{Aspectos relacionados ao monitoramento do talude experimental}

De maneira geral os tensiômetros instalados na área experimental apresentaram leituras coerentes com as precipitações, registraram elevação de poro-pressão de água nos dias chuvosos ou nos dias subseqüentes aos dias chuvosos, e redução ou manutenção de poro-pressões de água nos períodos de estiagem.

Gradientes de potencial hidráulico aplicados pelas raízes da vegetação natural, capim, retiraram água do solo na porção do talude com esse revestimento superficial, promovendo reduções significativas das poro-pressões de água nos períodos de estiagem, o que não ocorreu na porção do talude em que foi aplicada argamassa.

$\mathrm{Na}$ porção argamassada do talude e presença de solo argiloso gradientes de potencial gravitacional foram o único fator responsável pela redução das poropressões de água, durante períodos de estiagem, considerando que esse solo permaneceu saturado durante todo o período de monitoramento. $\mathrm{Na}$ porção argamassada com solo siltoso não foi possível verificar indícios de que gradientes de potencial térmico tenham produzido fluxos de vapor d'água para o meio externo, reduzido as poro-pressão de água, nos períodos de estiagem. Caso tenham ocorrido não foram mais importantes que os gradientes de potencial gravitacional.

Por diversas vezes durante o período de monitoramento se verificou a presença de lençol freático suspenso na crista do talude, onde há presença de solo argiloso. Isso pode ser explicado pela anisotropia relativa à permeabilidade desse solo e pela camada de argila com detritos vegetais, existente entre o aterro argiloso e o solo residual siltoso, que teria provocado retenção de água na camada argilosa.

Nos períodos chuvosos, o revestimento de argamassa provocou redução na infiltração de água de chuva no solo, provavelmente pelo efeito de regularização do terreno evitando o acúmulo de água, em comparação com o revestimento vegetal que a reteve. Por esse motivo a porção do talude revestida com argamassa 
apresentou em média poro-pressões de água pouco menores do que a porção com vegetação, nos períodos chuvosos do ano.

O solo siltoso apresentou em média menores poro-pressões de água do que o solo argiloso em todo o período de monitoramento, tanto nos períodos chuvosos como nos de estiagem. Em função de sua maior permeabilidade o silte apresentou maior fluxo de água para o interior do maciço, por ação dos gradientes de potencial gravitacional.

Na região do pé do talude pôde ser verificado o efeito da proximidade do nível d'água nas leituras de poro-pressão de água. Os tensiômetros instalados na porção argamassada do talude, mais próxima do nível freático, apresentaram leituras maiores que as leituras na porção com vegetação, mais afastada do nível d'água.

Análises das funções permeabilidade dos solos existentes no talude indicaram que a permeabilidade da argila manteve-se igual à sua permeabilidade saturada durante 0 período de monitoramento, e que a do silte caiu significativamente, mas não se aproximou da baixa permeabilidade da argila.

\subsection{Aspectos relacionados às análises de estabilidade do talude experimental}

Os resultados das análises de estabilidade do talude monitorado indicaram uma variação significativa no fator de segurança ao escorregamento do talude, como efeito das variações sazonais de poro-pressão de água, isto é, entre as datas em que foram registradas as maiores e as menores poro-pressões de água no talude durante o período em que foi monitorado.

Não pôde ser verificado efeito do revestimento superficial na estabilidade do talude monitorado. Os fatores de segurança ao escorregamento calculados para a porção argamassada do talude apresentaram resultados muito próximos dos obtidos para a porção com vegetação, tanto nos períodos chuvosos como nos de estiagem. 
Donde se concluiu que a aplicação do revestimento em argamassa sobre a superfície do talude não saturado, monitorado nesta pesquisa, não resultou em aumento significativo do fator de segurança ao escorregamento, em comparação com a porção do talude em que foi mantido o revestimento original, capim.

Provavelmente isso ocorreu devido à permeabilidade do revestimento não ser baixa o suficiente; devido à anisotropia com relação à permeabilidade dos solos existentes no talude induzirem ao fluxo de água pelas extremidades do revestimento; e devido ao fim do efeito positivo, redutor das poro-pressões de água, provocado pela evapotranspiração que era realizada pela vegetação removida da superfície do talude.

\subsection{Recomendações para futuras pesquisas}

Recomenda-se a execução de novos monitoramentos de taludes não saturados visando aprofundar o conhecimento sobre o fluxo de água no solo, sobre as variações de poro-pressão de água durante os períodos úmidos e secos do ano, e com o objetivo de se pesquisar outras formas de impermeabilização ou drenagem de taludes que possam reduzir as variações de poro-pressões de água durante os períodos chuvosos, época em que ocorrem os escorregamentos.

Recomenda-se que sejam desenvolvidas pesquisas envolvendo simulações de infiltração de água em solo não saturado baseadas em resultados de medições de poro-pressão de água em campo ou em colunas de solo, em laboratório, visando aferir resultados de simulações que, em alguns casos, como o apresentado neste trabalho, não representam as observações de campo. 


\section{REFERÊNCIAS BIBLIOGRÁFICAS}

ABRAMENTO, M. Resistência ao cisalhamento de solos não saturados:

considerações teóricas e estudo experimental sobre solo coluvionar das encostas da Serra do Mar. 1988. Tese (mestrado) - Escola Politécnica da Universidade de São Paulo - Departamento de Engenharia de Estruturas e Fundações, São Paulo, 1988.

ABRAMENTO M., PINTO, C. S. Resistência ao cisalhamento de solo coluvionar não saturado das encostas da Serra do Mar, Solos e Rochas, 16 (3), 145-158, 1993.

Aderson, M. V., Marinho, F. A. M. Variação sazonal da sucção em um talude de solo residual de gnaisse. Tese de mestrado apresentada à Universidade de São Paulo, 1999.

ALAN A. SMITH INC. MIDUSS for drainage systems design. Reference Manual. Version 2. Dundas, Ontario, Canada, 1986-2004.

ASTM International. Standard Test Method for Infiltration Rate of Soils in Field Using Double-Ring Infiltrometer, D 3385-03, 2003.

BISHOP, A. W. The principle of effective stress. Publish in Teknish Ukeblad, Vol. 106, n. 39, pp. $859-863,1959$.

BRAND, E.W., PREMCHITT, J., PHILLIPSON, H.B. Relationship between rainfall and landslides in Hong Kong. Proc. $4^{\text {th }}$ International Symposium on Landslides, Toronto, Vol.1, pp. 377-384, 1984.

BRASIL TURISMO. www.brasilturismo.com/saopaulo/.

Calle, J. A. C. Análise de ruptura de talude em solo não saturado. Tese de mestrado apresentada à Universidade de São Paulo, 2000. 
Campos, L. E. P. Influência da sucção na estabilidade de taludes naturais em solos residuais. Tese de mestrado apresentada à Pontifícia Universidade Católica do Rio de Janeiro, 1984.

CARDOSO JR., C. R.; FUTAI, M. M. Simulação do efeito de um fluxo transiente na estabilidade dos taludes. IV Conferência Brasileira sobre Estabilidades de Encostas - IV COBRAE. Volume I, pp. 453-463, Salvador - BA, 2005.

CARDOSO JR., C. R. Estudo do comportamento de um solo residual de gnaisse não saturado para avaliar a influência da infiltração na estabilidade de taludes. Dissertação de mestrado apresentada à Escola Politécnica da Universidade de São Paulo, São Paulo, 2006.

CARVALHO, C. S. Estudo da infiltração em encostas de solos insaturados na Serra do Mar. 1989. Tese (mestrado) - Escola Politécnica da Universidade de São Paulo Departamento de Engenharia de Estruturas e Fundações, São Paulo, 1989.

CRONEY, D.; COLEMAN, J. D. Pore Pressure and Suction in Soil. Proceeding of the Conference on Pore Pressure and Suction in Soils, pp. 31-37, Butterworths, London, 1961.

CRUZ, P. T. 100 barragens brasileiras - Casos históricos, materiais de construção, projeto. Oficina de Textos, 1996. $647 \mathrm{p}$.

CHILDS, E. C.; COLLIS-GEORGE, G. N. The permeability of porous materials. Proc. Royal Society of London, Series A, London, U.K., 201, pp. 381-390, 1950.

FREDLUND, D. G.; MORGENSTERN, N. R.; WIDGER, R. A. The shear strength oh unsaturated soil. Canadian Geotechinical Journal, Vol. 15, n. 3, pp. 313-321, 1978.

FREDLUND , D. G. Appropriate concepts and technology for unsaturated soils. Canadian Geotechnical Journal, Vol. 16, pp. 121-139, 1979. 
FREDLUND, D. G.; RAHARDJO, H. Soil Mechanics for Unsaturated Soils. New York: John Wiley \& Sons, 1993. $517 \mathrm{p}$.

FREDLUND, D. G.; XING, A. Equation for the soil-water characteristic curve.

Canadian Geotechnical Journal, Vol. 31, pp. 521-532, 1994.

FREDLUND, D. G.; XING, A; HUANG, S. Predicting the permeability function for unsaturated soils using the soil-water characteristic curve. Canadian Geotechnical Journal, Vol. 31, pp. 533-546, 1994.

FREDLUND, D. G.; XING, A.; FREDLUND, M. D.; BARBOUR, S. L. The relationship of the unsaturated soil shear strength to the soil-water characteristic curve. Canadian Geotechnical Journal, Vol. 33, pp. 440-448, 1996.

FUTAI, M. M. Estudo teórico-experimental do comportamento de solos tropicais não saturados: Aplicação a um caso de voçorocamento. 2002. 559 f. Tese (doutorado) COPPE - Universidade Federal do Rio de Janeiro, Rio de Janeiro, 2002.

FUTAI, M. M.; ALMEIDA, M. S. S.; LACERDA, W. A. Resistência ao cisalhamento de solos tropicais não saturados. $5^{\circ}$ Simpósio Brasileiro de Solos Não Saturados.

Volume I, pp. 43-54, São Carlos - SP, 2004.

FUTAI, M. M.; ALMEIDA, M. S. S.; LACERDA, W. A. The Shear Strength of Unsaturated Tropical Soils in Ouro Preto, Brazil. Fourth International Conference on Unsaturated Soils. Volume VI, pp. 1200-1211, Carefree - Arizona, 2006.

GEO-SLOPE International Ltd. SLOPE/W for slope stability analysis. User's Guide. Version 4, Calgary, Alberta, Canada, 1998.

GUIDICINI, G.; NIEBLE, C. M.. Estabilidade de taludes naturais e de escavação. Editora Edgard Blucher Ltda, São Paulo, pp. 194, 1983. 
GUIDICINI, G.; IWASA, O. Y. Ensaio de correlação entre pluviosidade e escorregamento em meio tropical úmido, São Paulo, IPT, 48 p. (IPT pub. 1080), 1976.

Hachich, W.; et al. Fundações Teoria e Prática, 1998.

Instituto de Pesquisas Tecnológicas do Estado de São Paulo - IPT. Mapa Geológico do Estado de São Paulo.

Instituto de Pesquisas Tecnológicas do Estado de São Paulo - IPT. Mapa Geomorfológico do Estado de São Paulo.

LEONG, E. C.; RAHARDJO, H. Permeability functions for unsaturated soils. Journal of Geotechnical and Geoenvironmental Engineering, ASCE , Vol.123, n. 12 , pp. 1118-1126, 1997.

LUMB, P. Slope failures in Hong Kong. Quarterly Journal of Engineering Geology, v.8, pp. 31-65, 1975.

MARINHO, F. A. M; CHANDLER, R. J. Cavitation and the direct measurement of soil suction. First International Conference on Unsaturated Soils, pp. 623-630, 1995, Paris.

MARINHO, F. A. M. A técnica do papel filtro para medição de sucção. In: ENCONTRO SOBRE SOLOS NÃO SATURADOS, 1995, Porto Alegre-RS.

MARINHO, F. A. M. Cavitação e a medida direta de sucção. In: ENCONTRO SOBRE SOLOS NÃO SATURADOS, 1995, Porto Alegre - RS.

MARINHO, F. A. M. Medição de Suç̧ão em Solos. Ñ SAT'97 - Solos Não Saturados. Vol. 2, pp. 373-397, 1997. 
MATOS, M. M. Stability of slopes in residual soils. 1974. 220 f. Master Thesis Department of Civil Engineering - University of Alberta, Canadá, 1974.

MEIN, R. G.; LARSON, C. L. Modeling infiltration during a steady rain. Water Resources Research, v. 9, n. 2, pp. 384-394, 1973.

MORGENSTERN, N. R.; MATOS, M. M. Stability of slopes in residual soils. PCSMFE, 5, Buenos Aires. Proceedings, v.3, p. 367-383.

O ESTADO DE SÃO PAULO. www.estadao.com.br

PINTO, C. S. Curso Básico de Mecânica dos Solos. Ed. Oficina de textos, São Paulo, 2000. 247 p.

PRANDINI, F. L. et alii. Atuação da cobertura vegetal na estabilidade de encostas: uma resenha crítica. Congresso Brasileiro de Florestas Tropicais, 2., Mossoró/RN. Separata.

RICHARDS, B. G. Behavior of unsaturated soils. Soil Mechanics - New Horizons, Ed. I. K. Lee, pp. 112-157, Newness - Butterworths, London, 1974.

Rezaur, R.B.; Rahardjo, H.; Leong, E.C. e Lee T.T. (2003). Hydrologic Behavior of Residual Soil Slopes in Singapore, Journal of Hydrologic Engineering, ASCE, p. 113144, May/June 2003.

Santos, C.R. Análise paramétrica da infiltração e sua influência na estabilidade de taludes em solo não saturado. Tese de mestrado apresentada à Universidade de São Paulo, 2004.

SIGRH - Sistema de Informações para o Gerenciamento de Recursos Hídricos do Estado de São Paulo. www.sigrh.sp.gov.br/cgi-bin/bdhm.exe/plu. 
SKEMPTON, A. W. Effective Stress in Soils, Concrete and Rocks. Conference Pore Pressure and Suction, pp. 277-313. Butterworths, London, 1960. (Selected papers on soil mechanics by A. W. Skempton, F. R. S.).

TATIZANA, C.; OGURA, A. T.; CERRI, L. E. S.; ROCHA, M. C. M. Análise de correlação entre Chuvas e Escorregamentos - Serra do Mar, Município de Cubatão. $5^{\circ}$ Congresso Brasileiro de Geologia de Engenharia - CBGE, Vol. 2, pp. 225 - 236, 1987.

TERZAGHI, K. The shear resistance of saturated soils. Proceeding International Conference Soils Mechanics Foundation Engineering. Vol. 1, pp. 54 - 56, 1936.

TERZAGHI, K. Mechanism of Landslides. 1950. Tradução - "Mecanismos de Escorregamentos de Terra", de E. Pichler. Departamento de Livros e Publicações do Grêmio Politécnico, São Paulo, 1967.

VANAPALLI, S. K.; FREDLUND, D. G.; PUFAHL, D. E; CLIFTON, A. G. Model for the prediction of shear strength with respect to soil suction. Canadian Geotechnical Journal, Vol. 33, pp. 379-392, 1996.

VAN GENUCHTEN, M. T. A closed form equation for predicting the water permeability of unsaturated soils. Soil Science Society of American Journal, Vol. 44, pp. 892-898, 1980.

VAUGHAN, P. R. Pore pressures due to infiltration into partly saturated slopes. First International Conference on Geomechanics in Tropical Lateritic and Saprolitic Soils, Brasília, Proceedings, Vol. 2, pp. 61-71, 1985.

VAUGHAN, P. R. Piezometers. Notas de aula. Imperial College, University of London, 1990.

VILAR, O. M. A simplified procedure to estimate the shear strength envelope of unsaturated soils. Canadian Geotechnical Journal, Vol. 43, 2006. 
WHITE, N. F.; DUKE, H. R.; SUNADA, D. K.; COREY, A. T.Physics of desaturation in porous materials. Journal of the irrigation and drainage division. Proceedings ASCE, Vol. 96, pp. 165-191, 1970.

WOLLE, C. M. Análise dos escorregamentos translacionais numa região da Serra do Mar no contexto de uma classificação de mecanismos de instabilização de encostas. 1988. Tese (doutorado) - Escola Politécnica da Universidade de São Paulo Departamento de Engenharia de Estruturas e Fundações, São Paulo, 1988.

ZHANG, L. L.; FREDLUND, D. G.; ZHANG, L. M.; TANG, W. H. Numerical study of soil conditions under which matric suction can be maintained. . Canadian Geotechnical Journal, Vol. 41, pp. 569-582, 2004. 